$$
\beta N L-62975
$$

\title{
FINAL REPORT: RISK ASSESSMENT FOR PRODUCED WATER DISCHARGES TO LOUISIANA OPEN BAYS
}

Anne F. Meinhold, Michael P. DePhillips, and Seymour Holtzman

March 221996

Prepared for Bartlesville Project Office United States Department of Energy Bartlesville, OK

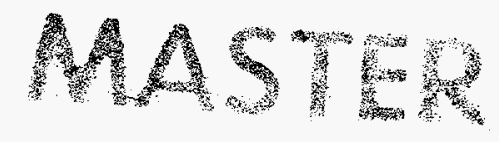

ITRE

BIOMEDICAL AND ENVIRONMENTAL ASSESSMENT GROUP ANALYTICAL SCIENCES DIVISION DEPARTMENT OF APPLIED SCIENCE BROOKHAVEN NATIONAL LABORATORY ASSOCIATED UNIVERSITIES, INC.

Under Contract No. DE-AC02-76CH00016 with the U. S. Department of Energy 


\section{DISCLAIMER}

This report was prepared as an account of work sponsored by an agency of the United States Government. Neither the United States Government nor any agency thereof, nor any of their employees, make any warranty, express or implied, or assumes any legal liability or responsibility for the accuracy, completeness, or usefulness of any information, apparatus, product, or process disclosed, or represents that its use would not infringe privately owned rights. Reference herein to any specific commercial product, process, or service by trade name, trademark, manufacturer, or otherwise does not necessarily constitute or imply its endorsement, recommendation, or favoring by the United States Government or any agency thereof. The views and opinions of authors expressed herein do not necessarily state or reflect those of the United States Government or any agency thereof. 


\section{DISCLAMMER}

Portions of this document may be illegible in electronic image products. Images are produced from the best available original document. 


\section{ACKNOWLEDGMENTS}

This work was supported by the United States Department of Energy, Office of Fossil Energy, with guidance from Dr. Brent Smith as project officer in Fiscal Years 1994 and 1995; and Dr. John Ford in Fiscal Year 1996. Dr. Leonard D. Hamilton, Dr. Sam Morris and Dr. Michael Rowe reviewed preliminary drafts of this report and made many useful suggestions. Ms. Sharon Baxter prepared the maps that appear in this report. The primary contractor for the field study mentioned in the text was Continental Shelf Associates, Inc. (CSA) in Jupiter, Florida. We thank Dr. David Gettleson and Dr. Alan Hart of CSA for their support. Steimle \& Associates, Inc., in Metairie, Louisiana performed the coastal sampling and the recreational fishermen survey used in the assessments presented in this report. Dr. Maureen Mulino and Mr. Michael Rayle of Steimle \& Associates, Inc. kindly provided preliminary data for these analyses. 


\section{CONTENTS}

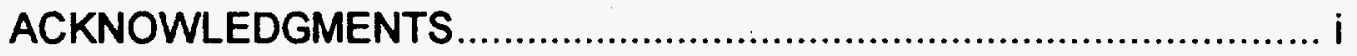

ACRONYMS

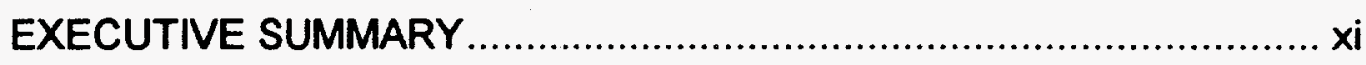

1 INTRODUCTION.

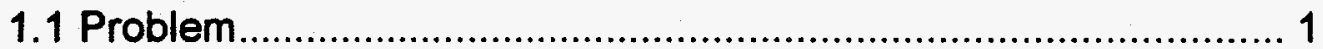

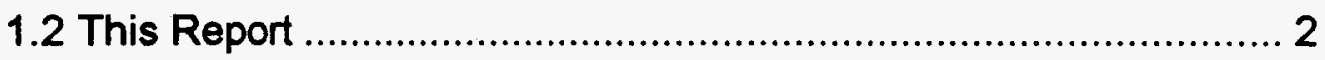

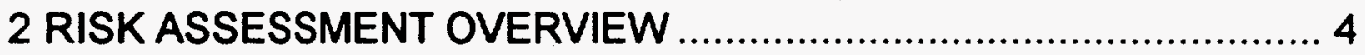

2.1 Risk Assessment and Risk Management ................................... 4

2.2 Human Health Risk Assessment............................................. 4

2.3 Ecological Risk Assessment ................................................. 5

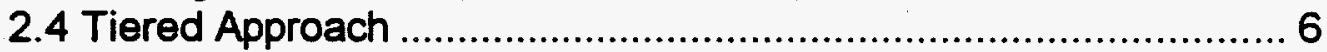

2.5 Probabilistic Analysis and Uncertainty ................................... 7

3 HAZARD ASSESSMENT AND RISK ASSESSMENT APPROACH $\ldots 8$

3.1 Background and Overall Approach ......................................... 8

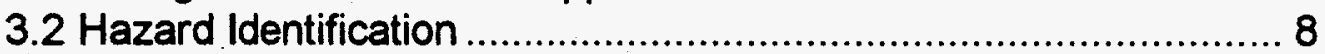

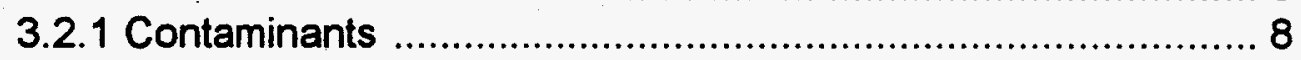

3.2.2 Exposure Pathways and Receptors ................................. 10

3.3 Risk Assessment Approach ................................................... 11

3.3.1 Data and Modeling Analyses ............................................. 11

3.3.2 Human Health and Ecological Risk Assessment .................. 12

4 USDOE FIELD STUDY PRELIMINARY DATA .............................. 14

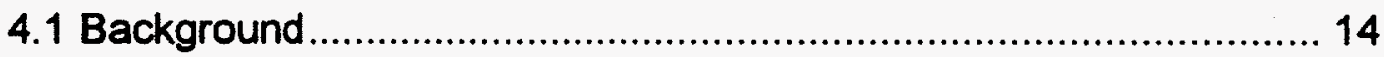

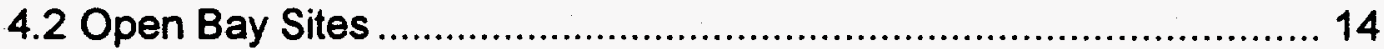

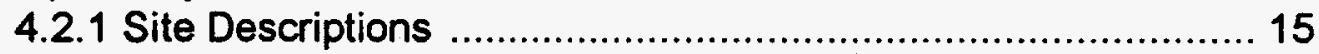

4.2.2 Discharge and Sampling Information ................................... 16

4.2.3 Radionuclides in Water and Biota...................................... 17

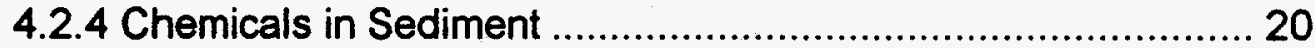

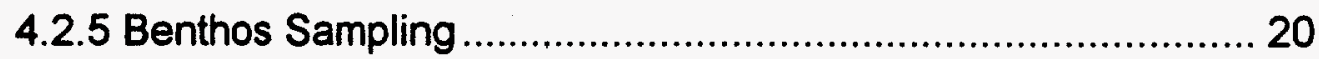

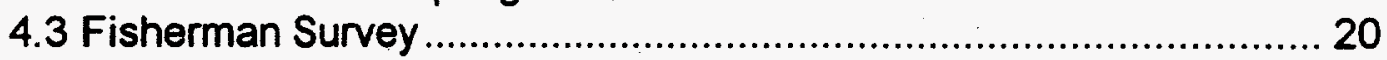

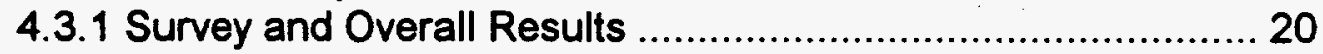

4.3.2 Estimation of Intake Rates .................................................. 21 
5 CHARACTERIZATION OF CONTINUING DISCHARGES ............... 24

5.1 Identification Of Continuing Discharges...................................... 24

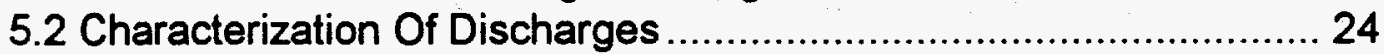

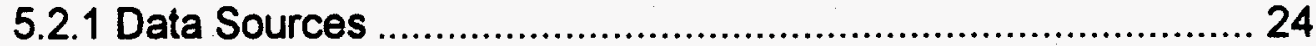

5.2.2 Depths and Discharge Rates ........................................... 26

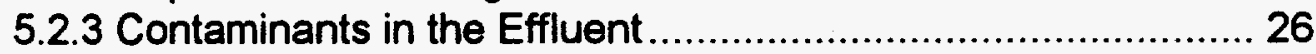

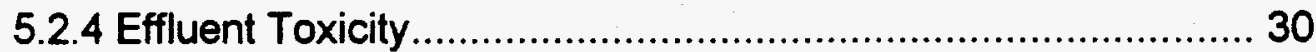

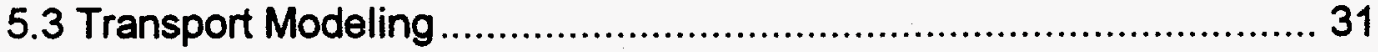

6 HUMAN HEALTH RISK ASSESSMENT FOR RADIUM .................... 37

6.1 Introduction and Approach .......................................................... 37

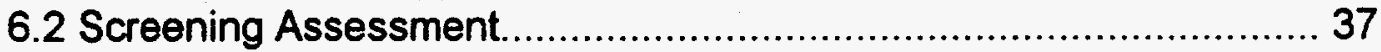

6.2.1 Concentrations in Edible Seafood....................................... 37

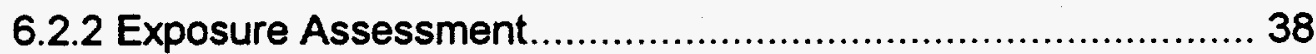

6.2.3 Dose-Response Assessment ........................................... 39

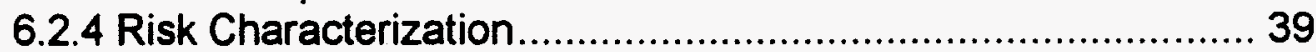

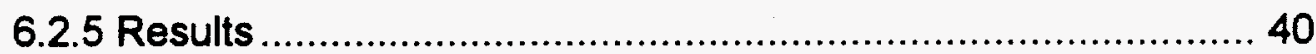

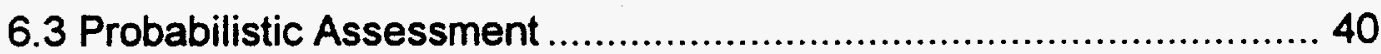

6.3.1 Exposure Assessment...................................................... 40

6.3.2 Dose-Response Assessment ........................................ 42

6.3.3 Risk Characterization...................................................... 43

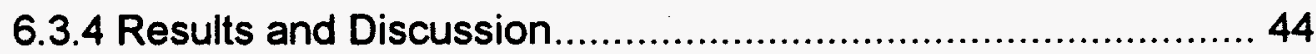

7 ECOLOGICAL RISK ASSESSMENT FOR RADIONUCLIDES........... 46

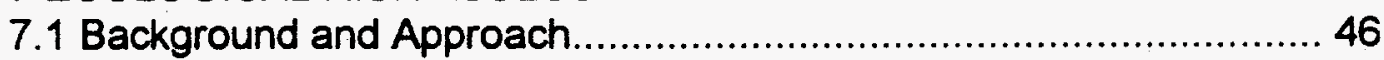

7.2 USDOE Open Bay Sites........................................................... 47

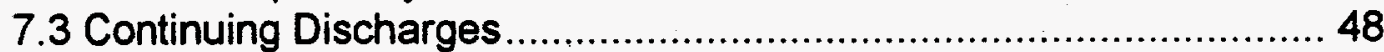

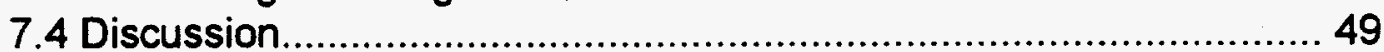

8 HUMAN HEALTH RISK ASSESSMENT FOR ORGANICS AND

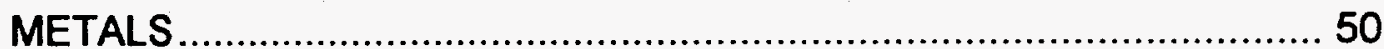

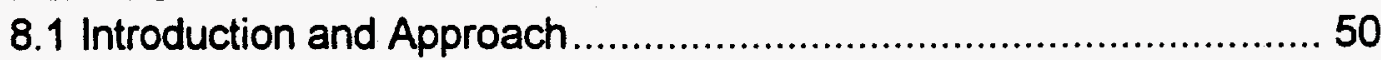

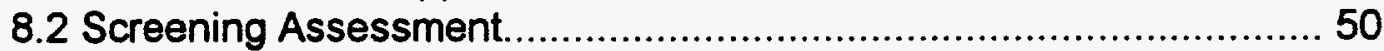

8.2.1 Concentrations in Water and Fish ................................... 50

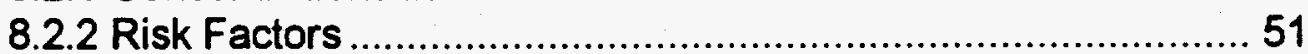

8.2.3 Exposure Assumptions....................................................... 54

8.2.4 Exposure Assessment and Risk Characterization ................ 54

8.2.5 Water Quality Criteria ....................................................... 55

8.2.6 Screening Analysis Results ............................................ 56 
8.3 Quantitative Analysis for Antimony, Cadmium, Mercury, Nickel, Zinc, Benzene and Phenol ....................................................... 56

8.4 Probabilistic Risk Assessment for Lead ......................................... 62

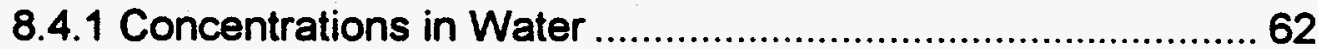

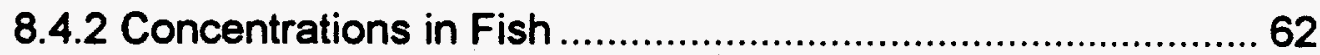

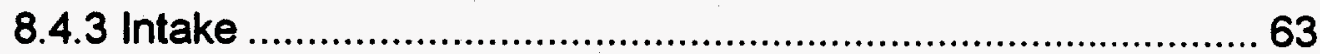

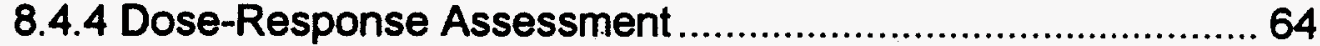

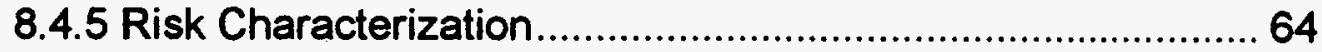

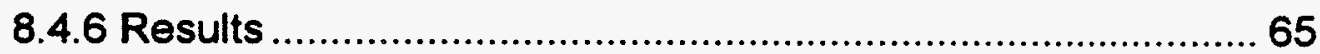

9 ECOLOGICAL RISK ASSESSMENT FOR METALS, ORGANICS,

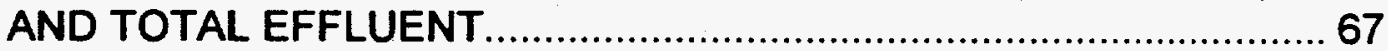

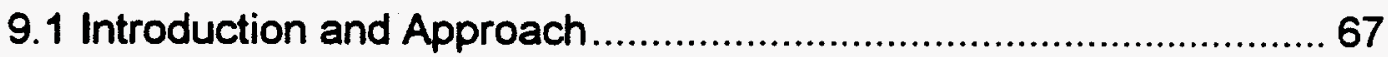

9.2 Sediment Toxicity -- USDOE Open Bay Sites............................... 67

9.3 Toxicity of Individual Produced Water Components -- Continuing Open Bay Discharges ................................................................ 76

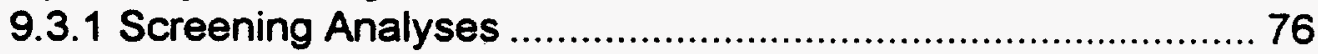

9.3.2 Quantitative Risk Assessment ............................................ 80

9.3.3 Relationships Between Screening and Probabilistic

Risk Assessment............................................................. 84

9.4 Toxicity of Whole Effluent-- Continuing Open Bay Discharges........ 84

9.5 Discussion.................................................................................. 92

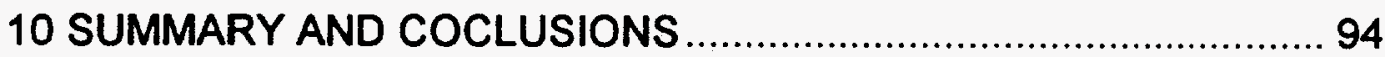

10.1 Human Health Risk Assessment for Radium ................................ 94

10.2 Ecological Risk Assessment for Radionuclides ........................... 94

10.3 Human Health Risk Assessment for Chemical Contaminants....... 94

10.4 Ecological Risk Assessment for Chemical Contaminants

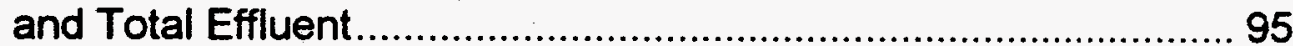

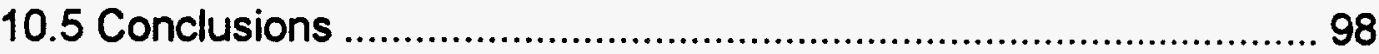

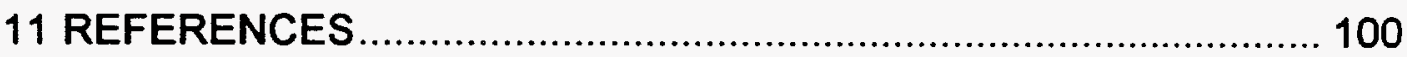

APPENDIX A. Preliminary Contaminant Data For USDOE

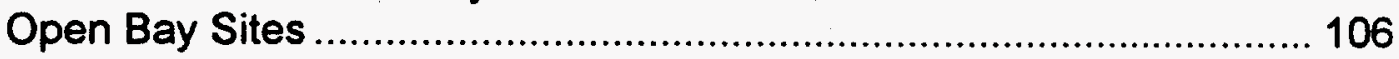

APPENDIX B. Characterization Of Continuing Open Bay Discharges... 126

APPENDIX C. Radionuclide Effects. 


\section{Figures}

4-1. Delacroix Island Oil and Gas Field Tank Battery \#1 sampling locations

4-2. Bay de Chene Field Tank Battery \#5 sampling locations

4-3. Number of times per week fish served 22

5-1. Assumed active discharges in open Louisiana bays 25

5-2. Lognormal tests: discharge rates of continuing open bay discharges.

5-3. Depths of platforms, continuing open bay discharges 28

5-4. Relationship between ${ }^{226} \mathrm{Ra}$ and ${ }^{228} \mathrm{Ra}$ concentrations in effluents

5-5. Relationships between discharge rates and modeled dilution factors in the plume at 50 and 200 feet from discharge. 36

8-1. Hazard quotient (HQ) for chronic oral exposure to cadmium 61

8-2. Incremental individual lifetime risk of cancer from benzene intake by ingesting fish (right marker on $x$ axis is at the 95th percentile).... 61

8-3. Relationship between intake of lead in recreationally caught fish and probability of exceeding $10 \mu \mathrm{g} / \mathrm{dl}$ blood lead for two age groups... 66

9-1. Distribution of chronic hazard quotients (CHQ) for contaminants that have a $\mathrm{CHQ} \geq 1$.

9-2. Logarithmic distribution of ratios between $\%$ effluent concentrations the LOEL \% effluent concentrations for inhibition of growth in Mysidopsis bahia in produced waters from Louisiana open bay platforms. 90

9-3. NOEL (as percent effluent) for growth inhibition as a power function of the NOEL for survival of Cyprinodon variegatus exposed to produced waters from Louisiana open bay platforms. 


\section{Tables}

4-1. Concentrations of radionuclides measured in discharge at Delacroix Island and Bay de Chene study sites.

4-2. Maximum radium concentrations measured in biota from the Delacroix Island and Bay de Chene study sites (pCi/g)

4-3. Derived lognormal intake distributions for fish caught near open bay platforms.

5-1. Platform depths and discharge rates

5-2. Contaminant concentrations in open bay produced water discharges in Louisiana (for contaminants reported above detection limits)... 28

5-3. Radium concentrations ( $\mathrm{pCi} / \mathrm{l}$ ) in open bay discharges 29

5-4. Results (percent effluent) of acute toxicity $\left(\mathrm{LC}_{50}\right)$ tests, Mysidopsis bahia and Cyprindon variegatus.

5-5. Results of chronic toxicity tests (NOEL, growth and survival, percent effluent)

5-6. CORMIX input parameters.

5-7. Estimates of dilution factors in the plume at 50 and $200 \mathrm{ft}$ 34

5-8. Dilution factors and effluent concentrations (percent effluent) in the plume, calculated by CORMIX for open bay discharges. 35

6-1. Maximum radium concentrations in biota measured at Delacroix Island and Bay de Chene Study Sites (pCi/g)

6-2. Screening analysis; estimated water and fish concentrations 200 feet from the discharge

6-3. Screening human health risk assessment for Delacroix Island and Bay de Chene study sites, and modeled continuing discharges; individual lifetime fatal cancer risk

6-4. Estimated radium concentrations in water and fish in the modeled plume $\mathbf{2 0 0}$ feet from modeled open bay discharges 
6-5. Risk factor distribution for ${ }^{226} \mathrm{Ra}$ and ${ }^{228} \mathrm{Ra}$ (lognormal distributions; individual lifetime fatal cancer risk per $\mathrm{pCi} /$ day).

6-6. Probabilistic risk assessment for radium in fishes at Delacroix Island and Bay de Chene sampling sites: individual lifetime fatal cancer risk

7-1. IAEA dose rate factors (mSv/hr per $\mathrm{Bq} / \mathrm{m}^{3}$ ).

7-2. Screening-level concentrations of radionuclides predicted for 200 feet at the Delacroix Island and Bay de Chene study sites.

7-3. Screening-level dose estimates for Delacroix Island and Bay de Chene study sites (mSv/d).

7-4. Screening-level concentrations of radionuclides predicted for 200 feet from open bay discharges.

7-5. Screening-level dose estimates for radium in continuing open bay discharges (mSv/d)

8-1. Estimated worst-case mean and maximum contaminant concentrations in the effluent, in the plume 200 feet from the discharge, and in edible fish.

8-2. RfDs, uncertainty factors (U), slope factors and human health water quality criteria.

8-3. Hazard quotients and cancer risk estimates 57

8-4. Water quality criteria hazard quotients (WHQ) at 200 feet 57

8-5. Distributions of concentrations of contaminant $(\mu \mathrm{g} / \mathrm{l})$ found in discharges from open bay platforms.

8-6. Predicted concentrations of contaminants $(\mu \mathrm{g} / \mathrm{l})$ in plumes, at 200 feet from discharges of produced waters.

8-7 Predicted concentrations of contaminants $(\mathrm{mg} / \mathrm{kg})$ in finfishes, assumed to live in plumes, within 200 feet from discharges of produced waters.

8-8. Parameters used in the exposure calculations. 59 
8-9. Probability that the HQ (from ingestion of fish caught within $200 \mathrm{ft}$ of a produced water discharge) equals or exceeds 1.0

8-10. Lead concentrations in open bay produced water discharges, and estimated concentrations in water and fish in the plume at 200 feet.

8-11. Total probability (\%) of exceeding a blood lead level of $10 \mu \mathrm{g} / \mathrm{dl} .65$

9-1. Proposed sediment quality criteria (from Long et al., 1995). 68

9-2. Measured metal concentrations that exceeded ERL sediment criteria (Long et al., 1995) at sampling stations around the Delacroix Island and Bay de Chene sites 69

9-3. Sediment samples from the Delacroix Island area that exceed ERL values (Long et al., 1995) for total and individual PAH concentrations.

9-4. Sediment samples from the Bay de Chene area that exceed ERL values (Long et al., 1995) for total and individual PAH concentrations.

9-5. PAH concentrations in marine sediments at Bay de Chene that exceed ERM concentrations

9-6. Screening concentrations of contaminants at 50 and 200 feet from continuing open bay discharges and water quality criteria

9-7. Screening-level Acute Hazard Quotients (AHQ): predicted concentrations at 50 feet/ acute water quality criteria 78

9-8. Screening-level Chronic Hazard Quotients (CHQ): predicted concentrations at 200 feet $/$ chronic water quality criteria

9-9. Distributions of concentrations of contaminants $(\mu \mathrm{g} / 1)$ found in discharges from open bay platforms.

9-10. Predicted concentrations of contaminants $(\mu \mathrm{g} / \mathrm{l})$ in plumes, at 200 feet from discharges of produced waters.

9-11. Chronic Toxicity Hazard Quotients (CHQ) ratios of contaminant concentrations to water quality criteria for chronic toxicity 
9-12. Contaminants with concentrations at 200 feet that were $\geq$ chronic toxicity criteria for marine organisms, and percent probability of exceeding those criteria.

9-13. Estimated effluent dilutions and concentrations at open bay discharges near the Louisiana coast (BPD = barrels per day)..... 86

9-14. Effluents $\geq L C_{5 p}$ at $50 \mathrm{ft}$ from discharges, and ratios of their concentrations to their respective $\mathrm{LC}_{50}$ values for each species. 87

9-15. Effluents $\geq L C_{5 p}$ at $200 \mathrm{ft}$ from discharges, and ratios of their concentrations to their respective $L_{50}$ values for each species.

9-16. Survival ratios (percent effluent at 200 feet: percent effluent NOEL).

9-17. Growth-inhibition ratios (percent effluent at 200 feet: percent effluent NOEL). 89

9-18. Sensitivity of results to 20 percent reductions of all effluent coricentrations, or when discharges equal or exceed $500 \mathrm{bbl} / \mathrm{d} . .91$ 


\section{ACRONYMS}

\begin{tabular}{ll} 
AHQ & Acute Hazard Quotient \\
BEAG & Biomedical and Environmental Assessment Group \\
BEDS & Biological Effects Database \\
BNL & Brookhaven National Laboratory \\
CHQ & Chronic Hazard Quotient \\
CORMIX & Cornell Mixing Zone Expert System Model \\
CSA & Continental Shelf Associates, Inc. \\
ERL & Effects Range Low \\
ERM & Effects Range Median \\
HEAST & Health Effects Assessment Summary Tables \\
HQ & Hazard Quotient \\
IAEA & International Atomic Energy Agency \\
ICRP & International Commission on Radiological Protection \\
IRIS & Integrated Risk Information System \\
LDEQ & Louisiana Department of Environmental Quality \\
LOAEL & Lowest Observed Adverse Effect Level \\
NCRP & National Council on Radiation Protection and Measurements \\
NOEL & No Observed Effects Level \\
NORM & Naturally Occurring Radioactive Material \\
PAH & Polycyclic Aromatic Hydrocarbon \\
RfD & Reference Dose \\
SEP & Sediment Equilibrium Partitioning \\
UF & Uncertainty Factor \\
USDOE & United States Department of Energy \\
USEPA & United States Environmental Protection Agency \\
WHQ & Water Quality Criteria Hazard Quotient \\
\hline
\end{tabular}




\section{EXECUTIVE SUMMARY}

\section{Introduction}

Potential human health and environmental impacts from discharges of produced water to the Gulf of Mexico are of concern to regulators at the State and Federal levels, the public, environmental interest groups and industry. Current and proposed regulations require a zero discharge limit for coastal facilities, based primarily on studies in low energy, poorly flushed environments. However, produced water discharges in coastal Louisiana include a number of open bay sites, where the potential human health and environmental impacts are likely to be smaller than those demonstrated for low energy canal environments, but greater than the minimal impacts associated with offshore discharges.

Additional data and assessments are needed to support risk managers at the State and Federal levels in the development of regulations that protect human health and the environment without unnecessary cost to the economic welfare of the region and the nation. This project supports the Natural Gas and Oil Initiative objectives to:

- improve coordination on environmental research;

- streamline State and Federal regulation;

- enhance State, and Federal regulatory decision making capability;

- enhance dialogue through industry/government/public partnerships; and

- work with States and Native American Tribes.

This report is part of a series of studies of health and ecological risks from discharges of produced water to the Gulf of Mexico, supported by the United States Department of Energy (USDOE). These assessments are coordinated with a field study managed by USDOE, titled "Environmental and Economic Assessment of Discharges from Gulf of Mexico Region Oil and Gas Operations" (USDOE Field Study).

Human health and ecological risk assessments for produced water discharges to open bays in Louisiana were done to support risk managers in developing regulations for discharges of produced water to coastal open bays. The human health and ecological risk assessments were done in a tiered approach. The initial human health and ecological risk assessments consist of conservative screening analyses meant to identify potentially important contaminants and to eliminate others from further consideration. More quantitative assessments were done for contaminants identified in the screening analysis as being of potential concern.

Data used in the assessment are from two major sources: 
- Data collected in the ongoing USDOE field study; and

- Data abstracted from the Louisiana Department of Environmental Quality (LDEQ) permit files for open bay sites in Louisiana that plan to continue to discharge produced water until January, 1997.

\section{Risk Assessment}

Risk assessment can be defined as the process of estimating magnitudes and probabilities of potential adverse effects on human health or the environment. Risk management involves the political, economic and social decisions and actions taken to accept, mitigate, or control potential risks. Risk assessments provide risk managers with the scientific information needed to balance the degree of risk permitted against competing risks and the cost of risk reduction.

The United States Environmental Protection Agency (USEPA) currently considers excess individual lifetime cancer mortality risks less than $1 \times 10^{-4}$ (one in ten thousand) to $1 \times 10^{-6}$ (one in one million) to be acceptable (Federal Register, 1991). No similar standard "acceptable risk" value is available for toxic effects - estimated doses or intakes are usually compared to a chemical specific reference dose to determine if toxic effects are expected.

A tiered approach to human health and ecological risk assessment is logical and cost-effective. In a tiered approach, the initial analysis is a conservative (i.e. worst case) screening step, designed to eliminate from further analyses contaminants and pathways that are not of concern in terms of potential impacts to human health or ecological values. Further analyses are unnecessary when use of conservative models and assumptions yield estimated risks that are small (i.e. individual lifetime fatal cancer risk less than $1 \times 10^{-6}$ or no toxic effects predicted). If a conservative analysis suggests that risks are high, a more detailed, comprehensive and realistic assessment is performed.

The state-of-the-science in risk assessment uses a probabilistic approach that explicitly considers uncertainties and variability in assumptions, data and results. Probabilities of effects, and uncertainties are explicitly considered in both the analysis and the expression of its result. 


\section{Hazard and Receptor Identification}

Many contaminants in produced water have known or suspected human health and or ecological effects at high exposures. Contaminants of special concern include: toxic metals such as lead, mercury and cadmium; potentially toxic organic compounds such as phenol and PAHs; and known or suspected carcinogens such as benzene and radionuclides.

Ingestion of contaminated fish is expected to be the most important exposure route for people, because many of the contaminants found in produced water are known to accumulate in edible fish and shellfish. The important receptors for radium discharged in produced water are recreational fishermen and their families.

Potential ecological receptors for contaminants in produced water include recreationally and commercially important fish and shellfish species, benthic invertebrates living close to the platforms, and threatened and endangered species living in open Louisiana bays. Potentially important exposure pathways include direct exposure in water or sediment, and ingestion in food, water or sediment.

\section{Risk Assessment Approach}

The overall approach was to use available data and modeling analyses for continuing open bay discharges, in a tiered assessment of human health and ecological risk. The initial analysis consisted of conservative screening assessments meant to identify contaminants of potential concern. More quantitative, probabilistic risk assessments were performed for contaminants identified in the screening analyses.

The data that form the bases of the risk assessments presented here include:

- Data collected in the ongoing USDOE field study:

- PAH and metal concentrations in sediment near two open bay discharges;

- radium concentrations in edible biota near two open bay discharges;

- radionuclides in the effluent of two open bay discharges; and

- fish ingestion rates for recreational fishermen and their families. 
- Data abstracted from LDEQ permit files for open bay sites in Louisiana that plan to continue to discharge produced water until January, 1997:

- location, depth and discharge rate data;

- data describing chemical concentrations in the effluents;

- data describing radionuclide concentrations in the effluents;

- results of toxicity testing on effluents.

The modeling analyses used the USEPA CORMIX model (Doneker and Jirka, 1990 ) and Louisiana's acute mixing zone of 50 feet, and chronic and human health mixing zone of 200 feet. These distances imply a risk management decision about the "acceptable" location for environmental impacts; and were used in the current risk assessment.

\section{USDOE Field Study Preliminary Data}

\section{Background}

Risk assessments are coordinated with a USDOE project titled " Environmental and Economic Assessment of Discharges from Gulf of Mexico Region Oil and Gas Operations" (referred to as the "USDOE Field Study"). Continental Shelf Associates, Inc. (CSA) was contracted to conduct the field study. The study includes 4 technical tasks, two of which are relevant to the risk assessment presented here:

- Task 4 - Monitoring of the Recovery of Impacted Wetland and Open Bay Produced Water Discharge Sites in Coastal Louisiana and Texas; and

- Task 6 - Synthesis of Seafood Catch, Distribution and Consumption Patterns in the Gulf of Mexico Region.

Steimle \& Associates, Inc. were subcontracted by CSA to perform the two tasks relevant to the risk assessments presented here (Tasks 4, 6). Available preliminary results were used in the current analysis. 


\section{USDOE Open Bay Sites}

The emphasis in the study of coastal sites is an assessment of the recovery of these sites from any impact from produced water discharges. Data were collected prior to the termination of discharge at three sites (including the two open bay sites discussed here), and several times after the discharge was terminated. The data used in the current risk assessments were limited to those collected before termination of the discharges. The open bay study sites were located at Delacroix Island and Bay de Chene.

The Delacroix Island Oil and Gas Field, located approximately 5.5 miles southeast of Delacroix, Louisiana, has been in production since the first well was drilled in the field in 1940. The area is part of a subsiding delta, which results in broken marsh and numerous small water bodies with few large open bays. The tank battery studied (Tank Battery \#1) is located in approximately 1.5 meters of water and discharges approximately 2,000 bbl/day. The Delacroix Island site is not located in a completely open bay, but was used in the assessment presented in this report with the understanding that impacts at the site may over-estimate impacts from true open bay discharges.

The Bay de Chene Field is located approximately 13 miles northwest of Grand Isle, Louisiana and is part of the Barataria Basin. The field has been in constant production since the first well was drilled in 1942. The tank battery studied (Tank Battery \#5) is located in Hackberry Bay, a large open bay typical of the Barataria system. The discharge is located in about 2.3 meters of water and discharges approximately $4,000 \mathrm{bbl} /$ day.

Concentrations of radionuclides were measured in discharges. Radium concentrations were measured in tissues of fish and shellfish at reference stations and the discharge station. Sediment PAH and metal concentrations were also available.

Both pre- and post-termination benthos were collected at the study sites, and preliminary data are available. The study (Mulino et al., 1995; 1996) found depressed numbers of species and individuals at and near the discharge during the pre-termination sampling, suggesting an impact on the benthos between 0 and 100 meters from the platform .

\section{Fishermen Survey}

Commercial fishermen (including oystermen) and recreational fishermen were surveyed by personal interview from May through November 1993 to determine categories of seafood taken over the previous three months, types of license(s) held, and information on the number, gender and ages of individuals in the household and their seafood consumption habits. Respondents were also 
interviewed about locations fished, estimated distances from oilfield structures, and species caught (Steimle \& Associates, Inc., 1995).

In this preliminary assessment, ingestion rates for recreational fishermen of fish caught near coastal platforms were derived from the reported data on meals per week. The data reported for meals per week had an arithmetic mean of 1.8, a standard deviation of 1.3, and a range of 0 to 15. A lognormal distribution of meals per week was used in calculating ingestion rates $(\mathrm{g} / \mathrm{d})$ of fish.

\section{Characterization of Continuing Discharges}

Louisiana Regulations (Title 33, March 20,1991) required termination of all produced water discharges to natural or man-made water bodies located in intermediate, brackish or saline marsh areas after January 1,1995, unless the discharge (s) have been authorized in an approved schedule for elimination or effluent limitation compliance. A variance through January, 1997 was granted (12/16/94) for permitted discharges located in open waters and at least 1 mile from any shoreline in Chandeleur Sound, Breton Sound, Barataria Bay, Caminada Bay, Timbalier Bay, Terrebonne Bay, East Cote Blanche Bay, West Cote Blanche Bay or Vermillion Bay. LDEQ identified produced water discharges in open bay areas that may qualify for this variance.

Information critical to an assessment of the environmental impact from a produced water discharge includes the depth of the platform and the rate of discharge. Water depths ranged from 4 to 18 feet (mean: 9.1 feet); and discharge rates ranged from 1 to $37,113 \mathrm{bbl} /$ day (mean: $4,527 \mathrm{bbl} /$ day).

Chemical contaminants and radionuclides measured in open bay produced water discharges were abstracted from LDEQ permit files. Data describing effluent toxicity tests were alșo abstracted from LDEQ permit files.

The USEPA surface water transport model CORMIX (Doneker and Jirka, 1990) was used to estimate the dilution expected 50 and 200 feet from open bay discharges $\left(D_{50} \mathrm{ft}\right.$ and $\mathrm{DF}_{200 \mathrm{ft}}$ ). Eight feet $(2.44 \mathrm{~m})$ was chosen to represent the assumed depth of the receiving water body for continuing open bay discharges in Louisiana. A range of discharge rates was modeled to cover the range of discharge rates for open bay sites. The following empirical relationshps were derived from the modeling results: 
For discharge rates $\leq 5000 \mathrm{bbl} / \mathrm{d}$

$$
\begin{array}{ll}
\mathrm{DF}_{50} \mathrm{t}=10633^{*}(\mathrm{DISCHARGE})^{-0.867} & (\mathrm{R}=0.997) \\
\mathrm{DF}_{200 \mathrm{t}}=46303^{*}(\mathrm{DISCHARGE})^{-0.946} & (\mathrm{R}=0.9997)
\end{array}
$$

For discharge rates $>5000 \mathrm{bbl} / \mathrm{d}$

$$
\mathrm{DF}_{200} \pi=36061 *(\mathrm{DISCHARGE})^{-0.762} \quad(R=0.9997)
$$

These empirical relationships were applied to distributions of discharge rates for open bay discharges to produce distributions of dilution factors for 50 and 200 feet. The dilution factor distributions were also used to develop distributions of percent effluent expected in the water column at 50 and 200 feet.

\section{Human Health Risk Assessment for Radium}

Screening and probabilistic human health risk assessments were done for open bay radium discharges in Louisiana.

In the conservative screening analysis, estimated risks for the ingestion of radium in fishes exceeded $1 \times 10^{-6}$ in all cases. Estimated cancer risks for fish sampled at reference stations at Delacroix Island and Bay de Chene (pretermination data) were similar to those for ingestion of fish caught near the discharges. Predicted screening-level risks were greater than $1 \times 10^{-3}$ for the modeled continuing discharges.

These results are from a conservative, screening level assessment, and do not represent best estimates of risk associated with radium discharged by open bay platforms. They do, however, suggest the need for a more detailed, probabilistic assessment.

A probabilistic risk assessment was done using distributions of: radium concentrations in fish (from field sampling and modeling); fish ingestion rates (from USDOE fishermen survey); and risk factors for cancer mortality.

Mean and median individual lifetime fatal cancer risks for both USDOE study sites (Delacroix Island and Bay de Chene; pre-termination data) were less than 1 $\times 10^{-5}$, and 95th percentile risks were less than $1 \times 10^{-4}$. Median individual lifetime fatal cancer risks for continuing open bay discharges were $1.4 \times 10^{-6}$, and 95 th percentile risks were $2.3 \times 10^{-5}$.

These results suggest that the ingestion of radium in fish, caught near open bay produced water platforms, does not present an important risk to human health. 


\section{Ecological Risk Assessment for Radionuclides}

This assessment used concentrations of radionuclides measured in the effluent at the two USDOE study sites, and radium concentrations reported in permit files for continuing open bay discharges, to assess potential ecological effects from radionuclides discharged in produced water. Worst-case water concentrations were predicted using a dilution factor that was smaller than the factor derived from modeling analyses. Predicted water concentrations were compared to screening dose-rate factors developed by the International Atomic Energy Agency (IAEA, 1988) that relate exposure of an organism to the concentration of each radionuclide in the water in which the organism lives. Estimated doses were compared to reference dose rates suggested by IAEA (1988).

None of the predicted doses to aquatic animals exceeded the range of 0.1-24 mSv/d that IAEA (1988) associated with a potential for only minor effects on individual animals. Because of the conservative nature of this initial analysis, it can be concluded that no effects on aquatic animals from radionuclides discharged in produced water to open bays in Louisiana are expected.

\section{Human Health Risk Assessment for Chemical Contaminants}

A human health risk assessment screen was done for metals and organic compounds measured in continuing open bay discharges. This analysis followed the USEPA approach to estimating risks from toxic materials and carcinogens by applying RfD (reference dose) and slope factor values to estimates of chemical intake rates (USEPA, 1989). Predicted water concentrations were also compared to human health water quality criteria developed by USEPA and the State of Louisiana.

Arsenic, chromium, copper, silver, naphthalene, toluene and xylenes were eliminated from further consideration. This screening step identified antimony, benzene, cadmium, lead, mercury, nickel, zinc and phenol as contaminants of potential concern.

More realistic and quantitative assessments were performed for contaminants identified in this screening analysis. The results show that intakes of contaminants discharged to open bays in produced water pose a negligible hazard to human health.

The potentially toxic contaminants examined (antimony, cadmium, mercury, nickel, zinc and phenol; lead was analyzed separately) all had low risks of toxic effects. The only contaminant that marginally exceeded its oral RfD value was cadmium. 
Because of the concern for lead exposure to children, and the current belief that the dose-response function for lead exposure does not have a threshold, lead was analyzed in a separate probabilistic risk assessment. Risk from ingestion of lead in fish caught near platforms only slightly exceeded risks from background intake of lead and was similar to risks from ingestion of lead in fish caught in the Gulf of Mexico but not near platforms.

For benzene (the only potential carcinogen of concern), the predicted distribution of values for incremental individual lifetime risk of cancer mortality had a mean value of $1.6 \times 10^{-6}$ and a 95th percentile value of $7.4 \times 10^{-6}$. This is within the range accepted by USEPA $\left(1 \times 10^{-6}\right.$ to $1 \times 10^{-4}$; Federal Register, 1991).

These analyses used several conservative assumptions. The first assumption was that all the fish spend all of their time living and feeding within the plume, although they probably spend only a fraction of time within a plume. The predicted concentrations represent values at the midline of the plume at 200 feet from the discharge. These values were generated by a model that underestimates dilution (Smith et al., 1993). It was also assumed that all the fish eaten by a person were captured at the midline of a plume, while people may eat fish from several sources. Although contaminant concentrations in water should increase with decreasing distances from a discharge, bioaccumulation in fish would be offset by expected reduced residence of fish within the smaller plume volumes.

\section{Ecological Risk Assessment for Chemical Contaminants and Effluent}

Three ecological risk assessments were performed:

- a screening assessment of chemical toxicity to benthic biota;

- an assessment of potential toxicity of individual produced water components to fish and crustaceans in the water column; and

- an assessment of whole effluent toxicity to fish and crustaceans.

\section{Screening Assessment Of Sediment Toxicity}

Sediment metal and PAH concentrations measured at the USDOE study sites (pre-termination data) were compared to proposed sediment quality criteria (ERM: Effects Range Median; ERL: Effects Range Low; Long et al., 1995).

None of the measured concentrations of metals in sediment samples exceeded their respective ERM values. In general, measured sediment concentrations were below the ERL, with the exception of arsenic and nickel. Each of these metals exceeded its ERL value in samples from at least one reference site, and each discharge site. There was no clear pattern of concentration with distance from a discharge. 
With the exception of acenaphthene, individual and total PAH concentrations exceeded ERL criteria at, and $100 \mathrm{~m}$ from the discharge at Delacroix Island. Acenaphthene concentrations exceeded the ERL values at the discharge, 100, 300 and $500 \mathrm{~m}$ sample sites. Neither individual nor total PAH concentrations in sediment samples from Delacroix Island exceeded ERM criteria.

Individual and total PAH concentrations exceeded ERL criteria at the discharge site, and $100 \mathrm{~m}$ and $300 \mathrm{~m}$ from the discharge at Bay de Chene. Individual and total PAH concentrations in samples from the discharge site exceeded ERM criteria.

In preliminary results of the benthos sampling performed at the USDOE study sites, depressed numbers of individuals and numbers of species were found only at distances less than $100 \mathrm{~m}$ from the discharges (Mulino et al.,1995; 1996). Although comparisons of PAH concentrations to sediment criteria were generally consistent with the results of benthos observations, they could not explain differences between the benthic biota at the two study sites. Mulino et al., $(1995 ; 1996)$ attributed the more severe impacts at Delacroix Island (smaller discharge) to hydrologic influences on salinity and oxygen content of the water.

These results are preliminary, and cannot be applied to all other open bay discharge sites with much confidence, but the discharge rates and depths of the Bay de Chene and Delacroix Island study sites are comparable (discharge rates are on high end of distribution) to those that are continuing to discharge.

\section{Assessment Of Potential Toxicity Of Individual Contaminants In The Water Column.}

Concentrations of contaminants in plumes were predicted from worst-case measurements in continuing open bay discharges (LDEQ permit files). These water column concentrations were compared to USEPA and Louisiana water quality criteria.

Predicted water concentrations exceeded acute water quality standards for copper, lead, nickel, silver and zinc. Chronic water quality criteria were exceeded for antimony, cadmium, copper, lead, mercury, nickel, silver, zinc and phenol. Arsenic, chromium, benzene, naphthalene and toluene were eliminated from further consideration.

A quantitative risk assessment was done for contaminants not eliminated by the initial screen. Distributions of predicted chemical concentrations were compared to acute and chronic toxicity criteria for marine biota. 
None of the predicted chemical concentrations (at $200 \mathrm{ft}$ ) exceeded their respective acute toxicity criteria. Antimony, phenol, and zinc concentrations did not exceed any of their respective chronic toxicity criteria. Less than five percent of the concentrations of cadmium, copper, lead, nickel and silver, at $200 \mathrm{ft}$, are expected to result in chronic toxicity to biota. More than $90 \%$ of the predicted concentrations of mercury are expected to be below its chronic toxicity criterion. Since these all represent midline values for the plumes, the expectation would be that environmental impacts of the individual chemicals would be limited.

\section{Assessment Of Whole Effluent Toxicity}

Standard laboratory test organisms, an amphipod (Mysidopsis bahia) and the sheepshead minnow (Cyprinodon variegatus), were used in toxicity tests that were reported in LDEQ permits. Predicted water column concentrations of effluents were compared with reported results of acute and chronic toxicity tests on diluted effluent samples. For the results of each type of toxicity test, data were expressed in the same way as the predicted water column concentrations: as percent effluent.

For discharges reported to the LDEQ, modeled relationships between discharge (flow) rates and dilution factors were used to estimate concentrations of effluents at $50 \mathrm{~m}$ and $200 \mathrm{~m}$ from discharges.

Acute toxicity test data consisted of mortality responses, expressed as an effluent median lethal concentration for an exposure duration of $96 \mathrm{hrs} \mathrm{(96-hr}$ $\mathrm{LC}_{50}$ ), or the effluent concentration which results in the mortality of $50 \%$ of the test organisms in a 96-hr exposure period. Acute toxicity ratios (AHQ) were calculated between the estimated percent effluent at $50 \mathrm{ft}$ and $200 \mathrm{ft}$ from the discharge and the available corresponding $\mathrm{LC}_{50}$ values ( $M$. bahia; $C$. variegatus) for each platform). Ratios of one or greater indicate potential lethality.

At $50 \mathrm{ft}, 15 \%$ of the modeled effluent concentrations exceeded their respective $L C_{50}$ values for $M$. bahia, and $5 \%$ exceeded their respective $L C_{50}$ values for $C$. variegatus. A $200 \mathrm{ft}, 15 \%$ of the modeled effluent concentrations exceeded their respective $L C_{50}$ value for $M$. bahia and $2.5 \%$ exceeded their respective $L C_{50}$ value for $C$. variegatus. The results suggest a potential for lethal effects for some discharges at 50 and at 200 feet.

Chronic toxicity ratios were calculated for the estimated percent effluent at $200 \mathrm{ft}$ and the available corresponding chronic NOEL values for survival and growth inhibition. Ratios greater than one suggest a potential for toxic effects.

At $200 \mathrm{ft}, 37 \%$ of the modeled effluent concentrations exceed their respective survival NOEL values for $M$. bahia, and $19 \%$ exceed their respective survival NOEL value for $C$. variegatus. At $200 \mathrm{ft}, 39 \%$ of the modeled effluent 
concentrations exceeded their respective growth-inhibition NOEL values for $M$. bahia, and $18 \%$ exceeded their respective growth-inhibition NOEL values for $C$. variegatus. Approximately two times more of the predicted effluent concentrations exceeded chronic NOEL values (both survival and growthinhibition) for $M$. bahia than for $C$. variegatus.

The results suggest a potential for chronic effects within 200 feet of some discharges. These results should be taken only as an indicator of potential toxicity. The percent effluent values exceeded their respective NOEL values by small amounts.

Since the percent effluent values compared to the NOEL in this analysis represent the concentrations at the midline of the plume at $200 \mathrm{ft}$ from the discharges, an organism would have to live totally in the plume, within $200 \mathrm{ft}$ of the discharges for at least the period of the chronic test to be affected. This is unlikely because the plume is a relatively small fraction of the volume of water within $200 \mathrm{ft}$ of a platform. That volume, in turn, is a small fraction of the body of water in which the discharge occurs. Therefore, major effects to local populations or to the ecology of the region around open bay discharges is not expected.

\section{Conclusions}

The tiered approach to risk assessment is a cost-effective way to provide information needed to make risk management decisions. This screening assessment for human health and ecological risks from open bay produced water discharges in Louisiana eliminated a number of contaminants from further consideration. More quantitative assessments were performed on contaminants of potential concern.

Human health risks from radium in produced water appear to be small. Ecological risks from radium and other radionuclides in produced water also appear to be small.

Intakes of chemical contaminants in fish caught near open bay produced water discharges are expected to posed a negligible toxic hazard or carcinogenic risk.

Potential impacts to benthic biota and fish and crustaceans in the water column are possible for some discharges within the $200 \mathrm{ft}$ mixing zone. Permanent damage to populations of organisms and ecosystems are not expected, because mixing zones represent relatively small volumes and animals are not expected to remain continuously in the plume. 


\section{References}

Doneker, R.L., and G. H. Jirka, 1990, Expert System for Hydrodynamic Mixing Zone Analysis of Conventional and Toxic Submerged Single Port Discharges (CORMIX 1) EPAV00/3-90/012, United States Environmental Protection Agency, Athens, Ga.

Federal Register, 1991, Environmental Protection Agency, National Primary Drinking Water Regulations; Radionuclides, 40 CFR Parts 141,142, 56:138:33050.

IAEA, 1988, Assessing the Impact of Deep Sea Disposal of Low Level Radioactive Waste on Living Marine Resources, Technical Reports Series No. 288, International Atomic Energy Agency, Vienna.

Long, E. R., D. D. Macdonald, S. L. Smith, F. D. Calder, 1995, "Incidence of Adverse Biological Effects Within Ranges of Chemical Concentrations in Marine and Estuarine Sediments", Environmental Management 19:81-97.

Mulino, M.M., M.F. Rayle, J.C. Francis and M.A. Poirrier, 1995, "Delineation of Biological Impact and Recovery of Selected Produced Water Discharges in Inshore Louisiana" in: Proceedings of the SPE/EPA Exploration and Production Conference, Houston, TX.

Mulino, M.M., M.F. Rayle, J.C. Francis and M.A. Poirrier, 1996, "Delineation of Benthic Impact and Recovery at Two Produced Water Discharge Sites in Inshore Louisiana" in: Produced Water and Environmental Aspects, Plenum Press, In Press.

NCRP, 1991, Effects of lonizing Radiation on Aquatic Organisms, NCRP Report No. 109, National Council on Radiation Protection and Measurements, Bethesda, Md.

Steimle \& Associates, Inc., 1995, Synthesis of Seafood Catch, Distribution, And Consumption Patterns in the Gulf of Mexico Region, Draft Report prepared for the United States Department of Energy, New Orleans, La.

Smith, J.P., H.L. Mairs, M.G. Brandsma, R.P. Meek, and R.C. Ayers, Jr. 1993. "Field Observations of Produced Water Dilution: Comparison with Dispersion Model Predictions", report prepared for the Offshore Operators Committee, August 13, 1993.

USEPA, 1989, Risk Assessment Guidance for Superfund, Volume I, Human Health Evaluation Manual (Part A) Interim Final, Office of Emergency and 
Remedial Response, EPA540/1-89/002, United States Environmental Protection Agency, Washington, D.C.

USEPA, 1992, Framework for Ecological Risk Assessment, Office of Research and Development, United States Environmental Protection Agency, Washington, D.C., EPA630/R-92/001. 


\section{INTRODUCTION}

\subsection{Problem}

Produced water discharged to coastal waters in Louisiana can contain a number of contaminants, including organic compounds, metals and radionuclides. Many of these contaminants are toxic to marine organisms at high concentrations. Most contaminants discharged in produced water occur naturally in the geologic reservoir along with the oil and gas. Biocides or other chemicals that may be toxic to aquatic organisms are added to some effluents.

Potential human health and environmental impacts from discharges of produced water to the Gulf of Mexico are of concern to regulators at the State and Federal levels, the public, environmental interest groups and industry. This area supports economically important commercial and recreational fisheries, unique, socially-valued ecosystems, and several endangered and threatened species.

In offshore and other high energy environments, produced water is diluted so rapidly that contaminants cannot be detected in the water column or sediment even a few meters from the outfall. Effects on marine life are likely to be minimal. In shallower, low energy coastal canal environments, contaminants were detected in water, sediment and organisms several hundred meters from the discharge. Effects on benthic organisms in shallow coastal settings and on organisms in the biofouling mat close to discharge points have been documented (Boesch and Rabalais, 1989; Gallaway et al., 1981).

Current and proposed regulations require a zero discharge limit for coastal facilities, based primarily on studies in low energy, poorly flushed environments. However, produced water discharges in coastal Louisiana include a number of open bay sites, where potential human health and environmental impacts are likely to be smaller than those demonstrated for low energy canal environments but greater than the minimal impacts associated with offshore discharges, .

Additional data and assessments are needed to support risk managers at the State and Federal levels in the development of regulations that protect human health and the environment without unnecessary cost to the economic welfare of the region and the nation. 


\subsection{This Report}

The United States Department of Energy (USDOE) has a program of research in the environmental aspects of oil and gas extraction. This program includes a project titled "Environmental and Economic Assessment of Discharges from Gulf of Mexico Region Oil and Gas Operations" (here called the USDOE field study). Part of this project involves a comprehensive sampling and analysis program for offshore and coastal platforms in the Gulf of Mexico. This sampling project will characterize the environmental impacts associated with the discharge of naturally occurring radioactive materials (NORM), metals and organics in produced water.

This report is part of a series of studies of the health and ecological risks from discharges of produced water to the Gulf of Mexico, supported by the USDOE. These assessments are being coordinated with the field study described above, using the collected data to perform human health and ecological risk assessments. These assessments will provide input to regulators in the development of guidelines and permits, and to industry in the development and use of appropriate discharge practices.

This project supports the Natural Gas and Oil Initiative objectives to:

- improve coordination on environmental research;

- streamline State and Federal regulation;

- enhance State, and Federal regulatory decision making capability;

- enhance dialogue through industry/government/public partnerships; and

- work with States and Native American Tribes.

This report presents human health and ecological risk assessments for produced water discharges to open bays in Louisiana. The risk assessments were done to support risk managers in developing regulations for discharges of produced water to coastal open bays. The human health and ecological risk assessments are presented in a tiered approach. The initial human health and ecological risk assessments consist of conservative screening analyses meant to identify potentially important contaminants, and to eliminate others from further consideration. More quantitative assessments were done for contaminants identified, in the screening analysis, as being of potential concern.

Data used in the assessment are from two major sources:

- Data collected in the ongoing USDOE field study

- contaminant concentrations in water, sediment and edible biota at two coastal discharges

- ingestion rates for recreational fishermen 
- Data abstracted from the Louisiana Department of Environmental Quality (LDEQ) permit files for open bay sites in Louisiana that plan to continue to discharge produced water until January, 1997

- location, depth and discharge rate data

- chemical and radionuclide concentrations in the effluents

- results of effluent toxicity testing

Section 2 gives an overview of human health and ecological risk assessment to help put the analyses presented here in perspective. Section 3 provides the hazard assessment portion of the risk assessment, and identifies the important receptors and pathways of concern. Section 3 also outlines the approach taken to the risk assessments presented in the rest of the report. The remaining sections (4 through 9) present the human health and ecological risk assessments for discharges of produced water to open bays in Louisiana. 


\section{RISK ASSESSMENT OVERVIEW}

\subsection{Risk Assessment and Risk Management}

Risk assessment can be defined as the process of estimating magnitudes and probabilities of potential adverse effects on human health or the environment. Risk management involves the political, economic and social decisions and actions taken to accept, mitigate, or control potential risks. Risk assessments provide risk managers with the scientific information needed to balance the degree of risk permitted against competing risks and the cost of risk reduction.

A risk assessment should be performed independently of risk management, but the needs and concerns of risk managers should be considered in the design of the risk assessment to ensure that the results are relevant, useable, and understandable to risk managers.

\subsection{Human Health Risk Assessment}

A health risk assessment for an environmental pollutant describes the discharge of the contaminant, its transport and fate in the environment, and the resulting human exposure. Human-health risks are then calculated based on data and models that relate exposures to health effects.

The most commonly used framework for human health risk assessment includes the following four phases (NRC, 1983):

- Hazard identification;

- Dose-response assessment;

- Exposure assessment; and

- Risk characterization.

Hazard identification involves the use of exposure and effects data from the laboratory and the field to determine whether the agent of concern can cause health effects and to identify what those effects are (NRC, 1983).

Dose-response assessment characterizes the relationship between administered dose and the incidence of an adverse effect. Dose-response information is usually derived from animal toxicology studies or from clinical studies or epidemiology studies of people exposed at high levels. Assumptions must be made about the comparability of the response in laboratory animals to that of humans. Statistical methods are usually necessary to extrapolate the doseresponse function from high experimental doses to the generally much lower doses in the human population. 
Exposure assessment estimates the magnitude, frequency and duration of exposure, and characterizes subgroups of the human populations subject to different levels of exposure. This phase includes estimating the source term, fate and transport of the contaminant(s) of concern, and subsequent human exposure.

Risk characterization integrates the results of the previous phases, estimates the incidence of an adverse human health effect under conditions defined in the exposure assessment, and describes the uncertainties in the data and assumptions. Human health risks are described as the probability of an adverse health effect (e:g., cancer death or toxic effect) in an individual of an exposed population (individual risk), or the number of health effects expected in the population (population risk) during a given time interval.

The United States Environmental Protection Agency (USEPA) currently considers excess individual lifetime cancer mortality risks less than $1 \times 10^{-4}$ (one in ten thousand) to $1 \times 10^{-6}$ (one in one million) to be acceptable (Federal Register, 1991). USEPA recently proposed standards for radionuclides in drinking water that the agency considers to be associated with an individual lifetime cancer fatality risk of $1 \times 10^{-4}$ (Federal Register, 1991). No similar standard "acceptable risk" value is available for toxic effects -- estimated doses or intakes are usually compared to a chemical specific reference dose to determine if toxic effects are expected.

\subsection{Ecological Risk Assessment}

Early environmental decision-making was based on qualitative descriptions of effects of pollutant discharges on organisms and the environment, with some reliance on the assumption that protection of human health would ensure adequate protection of the environment. Current information and environmental regulations suggest a need for a risk-based approach to decision-making for environmental protection.

With some modifications, and addition of important uncertainties, the general paradigm for human health risk assessment is now being applied to estimation of risks to the environment. The field is new and definitions are not standardized. For the purposes of this report, "environmental risk assessment" refers to an assessment of the risks to man from contaminants in the environment (air, water, soil or food). "Ecological risk assessment" refers to an assessment of risks to the natural environment (Suter, 1993). The receptors or values of concern in an ecological risk assessment may range from individual organisms to entire ecosystems and fundamental ecological processes.

Because of the number of different species in a community and the complexity of inter-species interactions and basic ecological processes, the level of 
organization for which the assessment is performed can vary widely (individual, population, community, ecosystem), and the potential endpoints for the assessment are many (death, acute or chronic toxicity, reproductive or developmental effects, disruption of basic processes). USEPA (1992) proposed a framework for ecological risk assessment that includes three phases:

- Problem formulation;

- Analysis (exposure and effects assessment); and

- Risk characterization.

The problem formulation phase identifies the factors to be considered in the assessment, and determines the scope and objectives of the analysis. This phase includes the preliminary data gathering and conceptual development needed to define the problem. Specific steps in the problem formulation phase include planning, identification of stressor characteristics, description of the ecosystem potentially at risk, identification of potential ecological effects, endpoint selection, and development of a conceptual model for the assessment.

In exposure assessment, environmental concentrations of the contaminant are described, and exposure of the organisms and ecosystems of concern are estimated. The exposure assessment estimates the transport of the contaminant through the environment, including its transformation and uptake by organisms.

In effects assessment, a dose-response relationship between exposure and effects is developed. An effects assessment determines the relationship between exposure to the contaminant and effects on the measurement endpoint. An effects assessment is usually based on extrapolating results of toxicity studies on standard individual test organisms to effects on individuals of other species, populations, communities and ecosystems.

Risk characterization integrates the estimates of exposure and dose-response relationships developed in the analysis phase to produce an estimate of the risk to the identified assessment endpoint.

\subsection{Tiered Approach}

A tiered approach to human health and ecological risk assessment is logical and cost-effective. In a tiered approach, the initial analysis is a conservative (i.e. worst case) screening step, designed to eliminate from further analyses contaminants and pathways that are not of concern in terms of potential impacts to human health or ecological values. Further analyses are unnecessary when use of conservative models and assumptions yield estimated risks that are small (i.e. individual lifetime fatal cancer risk less than $1 \times 10^{-6}$ or no toxic effects predicted). If a conservative analysis suggests that risks are high, a more detailed, comprehensive and realistic assessment is performed. 
Ecological risk assessments may be more qualitative than human health assessments because of the many sources of uncertainty in assessing risks to ecological values (USEPA, 1992).

\subsection{Probabilistic Analysis and Uncertainty}

The current application of the National Research Council risk assessment paradigm (NRC, 1983) to estimation of human health and ecological risk requires explicit description of uncertainties in assumptions, models and parameters, and incorporation of these uncertainties into a final expression of risk. Until recently, the common practice in risk assessment was to use conservative assumptions in a "worst case" analysis rather than to estimate uncertainty. This approach: obscures recognition of the degree of conservatism and the uncertainties in risk estimates; allows for improbable scenarios and results; and ignores the potentially excessive costs of decisions made based on conservative assumptions (Burmaster et al., 1990; Paustenbach et al., 1991).

As discussed above (Section 2.4), a conservative, screening level assessment is an appropriate first step in an assessment. A more quantitative and realistic analysis can be performed when the threshold established in the screening process is exceeded. The state-of-the-science in risk assessment uses a probabilistic approach that explicitly considers uncertainties and variability in assumptions, data and results. Probabilities of effects, and uncertainties are explicitly considered in both the analysis and the expression of its result.

A commonly used tool in probabilistic, quantitative risk assessment is Monte Carlo analysis. In a Monte Carlo analysis, a sample from the distribution of an input parameter is placed into a simulation to interact in a model with samples from other input parameters. The frequency of sampling within an independent variable depends on the relative frequency of a value in the frequency distribution (Paustenbach et al., 1991). 


\section{HAZARD ASSESSMENT AND RISK ASSESSMENT APPROACH}

\subsection{Background and Overall Approach}

Screening-level assessments were performed to identify potentially important contaminants and ecological receptors, and to eliminate others from further consideration. Based on the results of this preliminary analysis, more quantitative risk assessments were done for specific contaminants.

Two sources of data were used in the risk assessments: data collected in the USDOE field study and data abstracted from LDEQ permit files. These data sets and associated modeling analyses were used to assess potential human health and ecological risks associated with continuing open bay discharges of produced water in Louisiana.

This section:

- presents the hazard identification step for the human health and ecological risk assessments;

- briefly describes the data and modeling analyses used in the risk assessments presented in this report (given in detail in sections 4 and 5 and Appendices $\mathrm{A}$ and $\mathrm{B}$ ); and

- outlines the approach used in the human health and ecological risk assessments (presented in sections 6 through 9).

\subsection{Hazard and Receptor Identification}

Hazard identification involves the use of exposure and effects data from the laboratory and field to determine whether the agent of concern can cause health effects and to identify what those effects are (NRC, 1983). In the context of this report, hazard identification includes: identification of contaminants of potential concern in produced water, identification of important human receptors and exposure pathways, and a description of potentially important ecological effects and receptors.

\subsubsection{Contaminants}

Many contaminants in produced water have known or suspected human health and or ecological effects at high exposures. Contaminants of special concern include: toxic metals such as lead, mercury and cadmium; potentially toxic organic compounds such as phenol and PAHs; and known or suspected carcinogens such as benzene and radionuclides. 


\section{Radionuclides}

Radionuclides known to occur in produced water above background surface water concentrations include ${ }^{226} \mathrm{Ra},{ }^{228} \mathrm{Ra}$, and ${ }^{210} \mathrm{~Pb}$. Other decay products of radium $\left({ }^{210} \mathrm{Po},{ }^{228} \mathrm{Th},{ }^{222} \mathrm{Ra}\right.$ ) may also be expected in produced water.

The health effects of radionuclides can be attributed to their radioactive emissions. The alpha, beta and gamma radiation released by the decay of radionuclides cause ionization of cellular components which may result in the mutation or death of affected cells.

Current practice in radiation protection is to assume there is a cancer risk associated with even very small doses of radiation. Risk factors are derived from epidemiological data and extrapolated down to low doses to describe the cancer risk associated with small exposures. See Appendix $C$ for a more detailed discussion.

Most of the available studies of the effects of radiation on aquatic organisms are concerned with the induction of deterministic, somatic effects. These effects include increases in mortality and pathophysiological, developmental and reproductive effects. There is little information available concerning induction of cancer and genetic effects, although a few studies of stochastic genetic effects in organisms are available (Anderson and Harrison, 1986).

The National Council on Radiation Protection and Measurements (NCRP) and the International Atomic Energy Agency (IAEA) reviewed the literature on the effects of ionizing radiation on aquatic organisms, and suggested reference levels that would protect aquatic populations (NCRP, 1991; IAEA, 1988). Effects on aquatic organisms are discussed in more detail in Appendix $\mathrm{C}$.

\section{Chemical Contaminants}

USEPA publishes cancer slope factors, reference doses or other estimates in the IRIS data base (Integrated Risk Information System) and water quality criteria for many of the contaminants commonly found in produced water. As a first level screen, chemical contaminants with published water quality criteria, slope factors and reference doses were included in the analysis. Published reference values suggest a potential concern for human health effects.

Most chemical contaminants discharged in produced water present a potential human health hazard because of toxicity associated with ingestion in fish and shellfish. A few of the chemical contaminants found in produced water are suspected or known human carcinogens including benzene and arsenic. 
Effects on aquatic organisms may be associated with a number of contaminants found in produced water discharges. Water and sediment toxicity studies, and water quality criteria are available for a few contaminants suggesting reasonable concern for potential ecological effects. Toxicity testing of produced water effluents using standard laboratory test animals has shown a range of acute $\mathrm{LC}_{50}$ s and NOELs, again suggesting the potential for concern about effects to fish and shellfish species.

Effects on sediment communities have also been demonstrated (Armstrong et al., 1977; Rabalais et al., 1991), but the relationship between effects on number of species and individuals and chemical contaminants in sediments were site specific and not consistent across all studies. These studies suggest a potential for toxic effects to benthic communities living close to platforms.

\subsubsection{Exposure Pathways and Receptors}

Ingestion of contaminated fish is expected to be the most important exposure route for people, because many of the contaminants found in produced water are known to accumulate in fish and shellfish. The important receptors for radium discharged in produced water are recreational fishermen and their families. Recreational fishermen are important receptors because they may fish close to a platform, return often to the same fishing spot, and ingest a large percentage of fish caught near a platform. Mollusks and crustaceans are commercially important in the Gulf of Mexico, but most of the seafood caught near platforms by recreational fishermen are fish.

There may be some commercial fishing near coastal platforms but the amount of fish and shellfish impacted by contaminants discharged in produced water will be small because of the dilution with distance from a platform. Commercially caught fishes are marketed widely, making the prediction of an individual's consumption from a single source difficult (USEPA, 1990). Because the catch of sports fishermen is not diluted in this way, they represent the population most vulnerable to exposure by consumption of contaminated fishes from one location (USEPA, 1990). Some sports fishermen may sell or give away the fish they catch, but an analysis of their consumption and risk will result in a more conservative estimate of risk than an assessment of risk for the general public. Recreational fishermen may also include commercial fishermen who fish near offshore platforms and eat some of their catch.

Potential ecological receptors for contaminants in produced water include recreationally and commercially important fish and shellfish species, benthic invertebrates living close to the platforms, and threatened and endangered species living in open Louisiana bays. Potentially important exposure pathways include direct exposure in water or sediment, and ingestion in food, water or sediment. 


\subsection{Risk Assessment Approach}

The overall approach was to use available data and modeling analyses for continuing open bay discharges, in a tiered assessment of human health and ecological risk. The initial analysis consisted of conservative screening assessments meant to identify contaminants of potential concern. More quantitative, probabilistic risk assessments were performed for contaminants identified in the screening analyses.

\subsubsection{Data and Modeling Analyses}

The data that form the bases of the screening and probabilistic risk assessments presented here include:

- Data collected in the ongoing USDOE field study:

- PAH and metal concentrations in sediment near two open bay discharges;

- radium concentrations in edible biota near two open bay discharges;

- radionuclides in the effluent of two open bay discharges; and

- fish ingestion rates for recreational fishermen and their families.

- Data abstracted from LDEQ permit files for open bay sites in Louisiana that plan to continue to discharge produced water until January, 1997:

- location, depth and discharge rate data;

- chemical and radium concentrations in the effluents;

- results of toxicity testing on effluents

Data and modeling analyses that form the basis of the risk assessments are described in detail in sections 4 and 5 . Section 4 describes the USDOE field study. Preliminary results of sampling conducted at the two coastal sites in Louisiana are summarized. The results of the survey of recreational fishermen in Louisiana are described and a distribution of fish ingestion rates derived. These data were used in the risk assessments presented in sections 6 through 9.

Section 5 summarizes the data abstracted from the LDEQ permit files for assumed continuing open bay discharges in Louisiana. Discharge rates and platform depths are summarized. Available chemical and radionuclide effluent data are described. Data summarizing acute and chronic toxicity studies are also presented. A surface water transport model was used to estimate dilution factors with distance from the discharge, and this modeling analysis is 
presented. These data and modeling results were used in the risk assessments given in sections 6 through 9 .

\subsubsection{Human Health and Ecological Risk Assessments}

Human health and ecological risk assessments are presented separately. Risk assessments for radium and other radionuclides in produced water are presented separately from assessments for chemical contaminants.

The state of Louisiana has identified a standard acute mixing zone of 50 feet, and a standard chronic and human health zone of 200 feet from produced water discharges. These distances imply a risk management decision about the "acceptable" location for environmental impacts. These distances were used in the current risk assessment.

\section{Human Health Risk Assessment for Radium}

Screening and probabilistic human health risk assessments were done for open bay discharges of radium in Louisiana.

A screening assessment was performed using worst-case estimates of: concentrations in fish, ingestion rates, and dose-response factors to determine the need for a more quantitative analysis. Based on the results of these analyses, a probabilistic risk assessment was done using distributions of: radium concentrations in fish (from field sampling and modeling); fish ingestion rates (from USDOE fishermen survey); and risk factors.

\section{Ecological Risk Assessment for Radionuclides}

This assessment used concentrations of radionuclides measured in the effluent at the two USDOE study sites, and radium concentrations reported in permit files for continuing open bay discharges. Worst-case water concentrations were predicted using a dilution factor derived from the modeling analyses presented in section 5. Predicted water concentrations were compared to screening doserate factors developed by IAEA (1988). These dose-rate factors relate the radiation exposure to an organism to a unit concentration of the radionuclide in the water in which the organism lives. Estimated doses were compared to reference dose rates suggested by IAEA (1988).

\section{Human Health Risk Assessment for Chemical Contaminants}

A screening human health risk assessment was done for metals and organic compounds measured in continuing open bay discharges. This analysis followed the USEPA approach to estimating risks from toxic materials and carcinogens by applying RfD (reference dose) and slope factor values to 
estimates of chemical intake rates (USEPA, 1989a). Predicted water concentrations were also compared to USEPA and Louisiana human health water quality criteria.

For contaminants that were identified as being of potential concern in the screening analysis, a more quantitative risk assessment was performed, using distributions of contaminant concentrations in the discharges.

\section{Ecological Risk Assessment for Chemical Contaminants and Effluent}

Three assessments were performed in the ecological risk assessment:

1. Screening assessment of sediment toxicity: sediment metal and PAH concentrations measured at the USDOE study sites were compared to proposed sediment quality criteria.

2. Assessment of potential toxicity of individual contaminants in the water column: Worst-case predicted water column concentrations of contaminants measured in continuing open bay effluents (LDEQ permit files) were compared to USEPA and Louisiana water quality criteria. A more quantitative analysis was done for contaminants identified in the screening analysis as being of potential concern.

3. Assessment of effluent toxicity: Predicted water column concentrations of effluent were compared to results of acute and chronic toxicity tests performed in the laboratory with standard test organisms.

Section 6 presents the screening and probabilistic risk assessments for the human health effects of radium. Section 7 gives the screening assessment for ecological effects of radium and other radionuclides. Section 8 presents the screening risk assessment for the human health effects from metals and organic contaminants. The risk assessments for the ecological effects of individual produced water contaminants and effects associated with the total effluent are presented in section 9 . 


\section{USDOE FIELD STUDY PRELIMINARY DATA}

\subsection{Background}

This report is part of a series of studies of the human health and ecological risks associated with discharges of produced water to the Gulf of Mexico supported by USDOE. These risk assessments are coordinated with a USDOE project titled "Environmental and Economic Assessment of Discharges from Gulf of Mexico Region Oil and Gas Operations" (referred to as the "USDOE Field Study").

Continental Shelf Associates, Inc. (CSA) was contracted to conduct the field study. The objective of the project is to increase the base of scientific knowledge concerning the following topics:

- The fate and environmental effects of contaminants found in produced water;

- The economic impacts of proposed regulations on offshore oil and gas producers of the Gulf of Mexico region; and

- The catch, consumption, and human use patterns of seafood species collected from coastal and offshore waters of the Gulf of Mexico.

The study includes 4 technical tasks, two of which are relevant to the risk assessments presented here:

- Monitoring of the Recovery of Impacted Wetland and Open Bay Produced Water Discharge Sites in Coastal Louisiana and Texas (Task 4); and

- Synthesis of Seafood Catch, Distribution and Consumption Patterns in the Gulf of Mexico Region (Task 6).

Steimle \& Associates, inc. were subcontracted by CSA to perform the two tasks (Tasks 4,6 ) relevant to these risk assessments. Preliminary results from Tasks 4 and 6 are available, and were used in the current analyses. The following sections summarize the preliminary data available from the Task 4 and Task 6 work, and derive or summarize the data used in subsequent sections of the report.

\subsection{Open Bay Sites}

The data and descriptions of the study sites were abstracted from material provided by Steimle \& Associates, Inc. The emphasis in the study of coastal sites is an assessment of the recovery of these sites from any impact from produced water discharges. Data were collected prior to the termination of discharge at three sites (including the two open bay sites discussed here), and several times after the discharge was terminated. The preliminary data 
presented in this section are limited to those collected before termination of the discharges.

\subsubsection{Site Descriptions}

\section{Delacroix Island}

The Delacroix Island Oil and Gas Field located approximately 5.5 miles southeast of Delacroix, Louisiana, has been in production since the first well was drilled in the field in 1940. The area is part of a subsiding delta, which results in broken marsh and numerous small water bodies with a few large open bays. The tank battery studied (Tank Battery \#1) is located in approximately 1.5 meters of water. The Delacroix Island site is not located in a completely open bay, but will be used in the assessment presented in this report with the understanding that the impacts from the site may over-estimate impacts from true open bay discharges.

Salinities in the Delacroix Field vary widely between seasons and years, with late summer/fall salinities being the most stable. Spring salinities are the lowest experienced during the year due to the influence of the Mississippi River. The influence of the Mississippi River is particularly noticeable in this area because of the proximity of the Caernarvon Diversion.

The bottom substrate in areas of subsiding marsh like the Delacroix Island area varies from soft, fine grained sediments in open water to old root mat which is firmer and may persist for many years.

The Delacroix Island area is typical of many brackish habitats in Louisiana inshore waters in that its inhabitants are eurytolerant opportunistic species. Commercially important species in this area include the American Oyster (Crassostrea virginica), the blue crab (Callinectes sapidus), brown shrimp (Penaeus aztecus) and white shrimp (Penaeus setiferus).

The area around the Delacroix Field is marginal for oysters, although during some years oyster crops can be successful. Crabs are harvested extensively year round. Commercial and recreational shrimping is conducted in this area. Recreational and commercial finfishing is also popular. Red drum or redfish (Sciaenops ocellatus) and speckled trout (Cynoscion nebulosus) are the most prized species in inshore areas. Both of these species are most available in the late fall and winter months. Flounder (Paralicthys lethostigma) are most abundant in the fall months and Croaker (Micropogonias undulatus), spot (Leiostomus xanthurus), sand seatrout (Cynoscion arenarius), black drum (Pogonias cromis) and sheepshead (Archosargus probatocephalus) are fished inshore year round. 


\section{Bay de Chene}

The Bay de Chene Field is located approximately 13 miles northwest of Grand Isle, Louisiana and is part of the Barataria Basin. The field has been in constant production since the first well was drilled in 1942. The tank battery studied (Tank Battery \#5) is located in Hackberry Bay, a large open bay typical of the Barataria system. The discharge is located in about 2.3 meters of water.

Salinities in the Bay de Chene Field vary during the year with the lowest salinities occurring when the Mississippi influences the area. The bottom substrate in most open water areas is soft fine grain sediments. Portions of the bay have been altered by the planting of Rangia shell by the Louisiana Wildlife and Fisheries for oyster culture One of these planted areas on the west side of the bay was chosen as a reference site because no drilling was allowed on shell planting sites.

The Bay de Chene habitat is mesohaline (5 to $18 \mathrm{ppt}$ ) most of the year, and the organisms that characterize this habitat are euryhaline and opportunistic.

Commercially harvested species are identical to those harvested at Delacroix. The American Oyster ( $C$. virginica) is cultivated on numerous leases in the area. Blue crab ( $C$. sapidus) are harvested year round. Brown ( $P$. aztecus) and white $(P$. setiferus) shrimp are harvested commercially and recreationally.

Recreational and commercial finfishing are also conducted in this area. Red drum or redfish (S. ocellatus) and speckled trout (C. nebulosus) are the most prized species in inshore areas. Both of these species are most available in the late fall and winter months. Flounder ( $P$. lethostigma) are most abundant in the fall months and croaker (Micropogonias undulatus), spot (Leiostomus $x a n t h u r u s)$, sand seatrout ( $C$. arenarius), black drum ( $P$. cromis) and sheepshead ( $A$. probatocephalus) are fished inshore year round.

\subsubsection{Discharge and Sampling Information}

\section{Delacroix Island Tank Battery \#1}

Discharge rates in LDEQ files (Discharge Monitoring Reports) for 1990-1992 average 1,741 BPD for this site. At the time of termination (April 1993) the volume of produced water fluctuated between 1,964 and 1,978 BPD for the period 26 March to 19 April 1993, when there were 11 wells in production. Discharge volumes from 19 to 25 March ranged from 2,246 to 2,256 BPD, with 12 wells in production.

Sampling at the Delacroix Island study site was conducted according to the station layout shown in Figure 4-1. Biota were collected using otter trawls, gill 
nets and crab traps at the two reference stations (R1 and R2) and the discharge station. Only species of commercial or recreational importance were retained. Animals were placed on ice and frozen within 12 hours of collection.

Bay de Chene Tank Battery \#5

The LDEQ data base shows a one-time sampling record of 3,666 BPD. This discharge terminated on 15 October 1993. At the time of the pre-termination survey, data provided by Texaco indicated that the discharge was for four wells, with a discharge volume of $3,825 \mathrm{BPD}$.

Sampling at the Bay de Chene study site was conducted according to the station layout in Figure 4-2. Biota were collected using otter trawls, gill nets and crab traps at the two reference stations and the discharge station. Only species of commercial or recreational importance were retained. Animals were placed on ice and frozen within 12 hours of collection.

\subsubsection{Radionuclides in Water and Biota}

Average concentrations of radionuclides in the discharges are given in Table 4-1. Maximum concentrations of ${ }^{226} \mathrm{Ra}$ and ${ }^{228} \mathrm{Ra}$ measured in croaker, spot, sea trout, blue crab and shrimp at the discharge and highest of the reference stations for each site are given in Table 4-2. Preliminary results of tissue analyses for ${ }^{226} \mathrm{Ra}$ and ${ }^{228} \mathrm{Ra}$ are given in Appendix $\mathrm{A}$.

Table 4-1. Concentrations of radionuclides measured in discharge at Delacroix Island and Bay de Chene study sites.

\begin{tabular}{|c|c|c|}
\hline Radionuclide & $\begin{array}{c}\text { Delacroix Island } \\
\text { (pCi/l) }\end{array}$ & $\begin{array}{c}\text { Bay de Chene } \\
\text { (pCi/l) }\end{array}$ \\
\hline & & 60.3 \\
\hline${ }^{210} \mathrm{~Pb}$ & 78.0 & $<2.0$ \\
\hline${ }^{210} \mathrm{Po}$ & $<1.1$ & 162.5 \\
\hline${ }^{226} \mathrm{Ra}$ & 218.5 & 317.5 \\
\hline${ }^{228} \mathrm{Ra}$ & 264.5 & 15.0 \\
\hline${ }^{228} \mathrm{Th}$ & 154.5 & \\
\hline
\end{tabular}




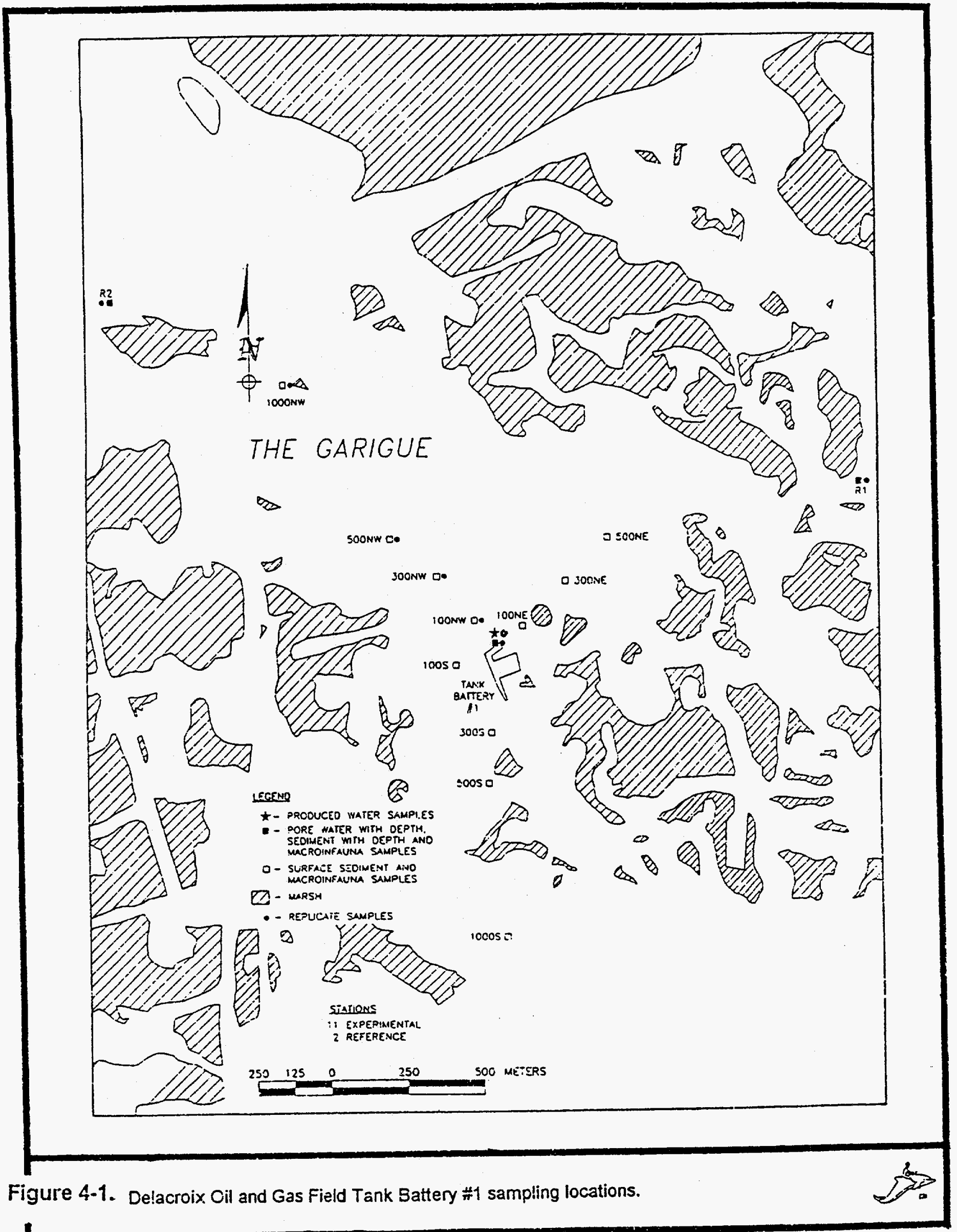




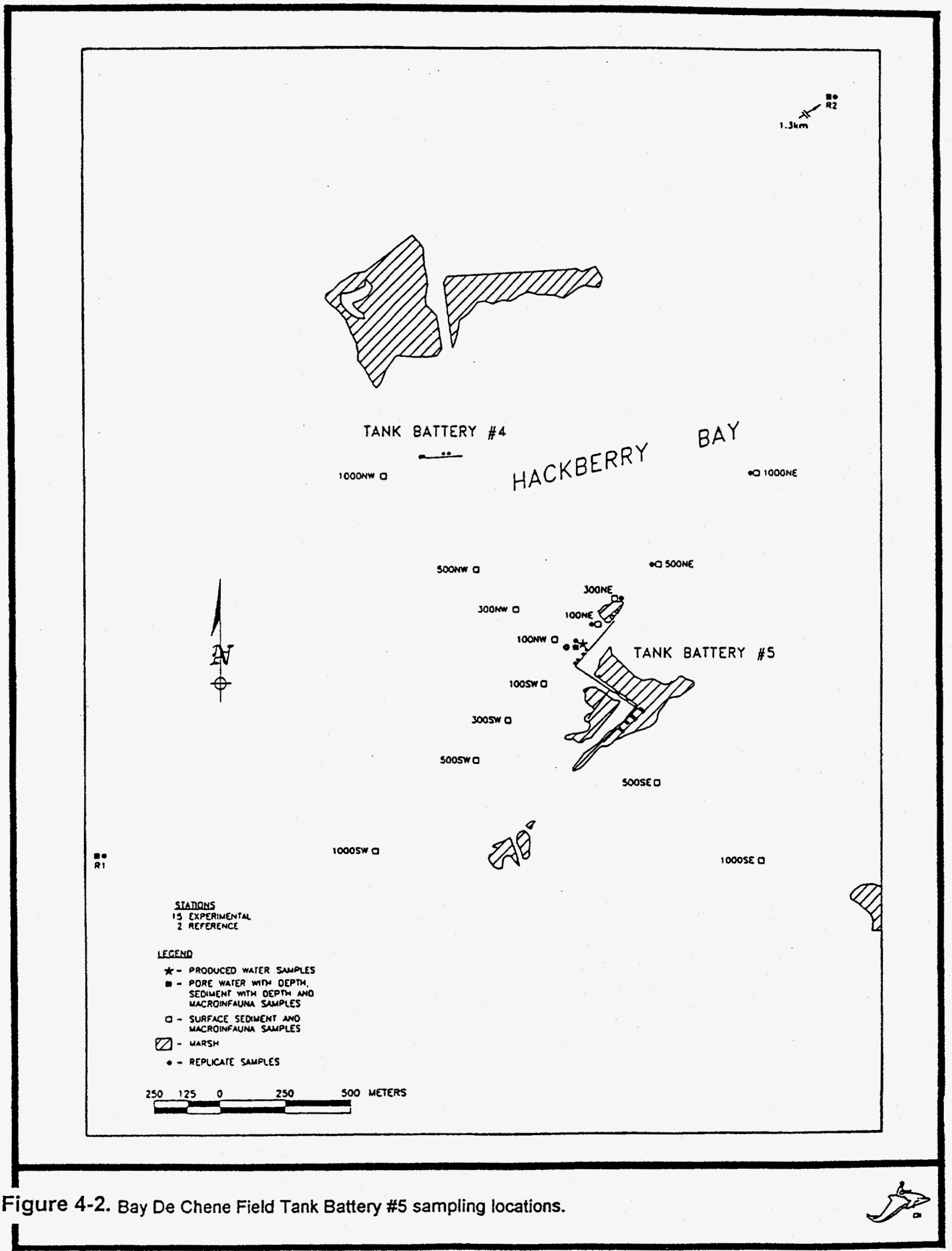


Table 4-2. Maximum radium concentrations measured in biota from the Delacroix Island and Bay de Chene study sites (pCi/g) (pre-termination samples).

\begin{tabular}{|c|c|c|c|c|c|c|c|c|}
\hline & \multicolumn{4}{|c|}{ Delacroix Island } & \multicolumn{4}{|c|}{ Bay de Chene } \\
\hline & \multicolumn{2}{|c|}{ Discharge } & \multicolumn{2}{|c|}{ Reference } & \multicolumn{2}{|c|}{ Discharge } & \multicolumn{2}{|c|}{ Reference } \\
\hline & ${ }^{220} \mathbf{R a}$ & ${ }^{226} \mathbf{R a}$ & ${ }^{236} \mathbf{R a}$ & ${ }^{228} \mathbf{R a}$ & ${ }^{260} \mathrm{Ra}$ & ${ }^{208} \mathbf{R a}$ & ${ }^{206} \mathrm{Ra}$ & ${ }^{26} \mathbf{R a}$ \\
\hline croaker & 0.005 & 0.112 & 0.063 & 0.021 & 0.024 & 0.094 & 0.032 & 0.05 \\
\hline spot & 0.002 & 0.076 & 0.002 & 0.107 & 0.034 & 0.086 & 0.029 & 0.01 \\
\hline sea trout & NS & NS & NS & NS & 0.021 & 0.159 & 0.016 & 0.042 \\
\hline blue crab & 0.025 & 0.09 & 0.012 & 0.046 & 0.023 & 0.059 & 0.024 & 0.01 \\
\hline shrimp & NS & NS & NS & NS & 0.011 & 0.01 & 0.027 & 0.124 \\
\hline
\end{tabular}

NS $=$ no sample

\subsubsection{Chemicals in Sediment}

Preliminary results of the chemical analyses (PAHs and metals) of sediments are given in Appendix A.

\subsubsection{Benthos Sampling}

Both pre- and post-termination benthos were collected at the study sites, and preliminary data are available. The study (Mulino et al., 1995; 1996) found depressed numbers of species and individuals at and near the discharge during the pre-termination sampling, suggesting an impact on the benthos between 0 and 100 meters from the platform.

\subsection{Fishermen Survey}

\subsubsection{Survey and Overall Results}

The following material and data from the fishermen survey and its preliminary results were abstracted from Steimle \& Associates, Inc.(1995).

Commercial fishermen (including oystermen) and recreational fishermen were surveyed by personal interview from May through November 1993 to determine categories of seafood taken over the previous three months, types of license(s) held, and information on the number, gender and ages of individuals in the household and their seafood consumption habits. Respondents were also interviewed about locations fished, estimated distances from oilfield structures, and species caught.

To determine the distribution of the catch, all fishermen were asked to estimate by species the percentage sold, the percentage given away to others, and the percentage kept for personal consumption. Fishermen were also asked to estimate the frequency of seafood consumption and cooking methods employed. 
Processing plants and wholesalers in Texas and Louisiana were surveyed to determine their sources of seafood (i.e. in-state vs. out-of-state), and the origin of the seafood sold (i.e. fishing zones and ports of commercial fishermen). Site surveys of seafood retailers were conducted to determine the types of shellfish and saltwater finfish sold, the parts of the seafood sold, and the types of prepared seafood sold. Restaurant surveys asked respondents about the source, quantities and method of preparation of seafood sold/served by the restaurant.

Finfishing was the most popular form of recreational fishing (95\%) with most fishermen possessing an in-state license (92\%). The majority of respondents fished from a private boat inshore $(62 \%)$, often near an oilfield structure, and most commonly caught speckled sea trout and red snapper.

On average, fishermen reported keeping $80 \%$ of the finfish; $97 \%$ of the blue crab catch; and $83 \%$ of shrimp for personal consumption. They reported serving seafood 1.8 times per week on average. Their preference was to consume the meat only from the fish over $90 \%$ of the time, and the most popular cooking method was frying $(30 \%)$.

\subsubsection{Estimation of Intake Rates}

Variables needed for the human health risk assessment include those that contribute to an estimate of the ingestion rate of fish caught near (less than $1,000 \mathrm{ft} ; 300 \mathrm{~m}$ ) a coastal platform in Louisiana. Data collected by the survey (Steimle \& Associates, Inc., 1995) include the following:

- amount of fish caught per trip

- number of seafood eaters in fishermen's family

- number of trips near structures

- number of trips inshore vs. offshore

- fraction of catch kept

- number of days since last seafood meal

- number of times per week fish served

In this preliminary assessment, ingestion rates for recreational fishermen of fish caught near coastal platforms were derived from the reported data on meals per week (Figure 4-3). A lognormal distribution was assumed (arithmetic mean of 1.8 , a standard deviation of 1.3 , and a range of 0 to 15 ). 
Figure 4-3. Number of times per week fish served.

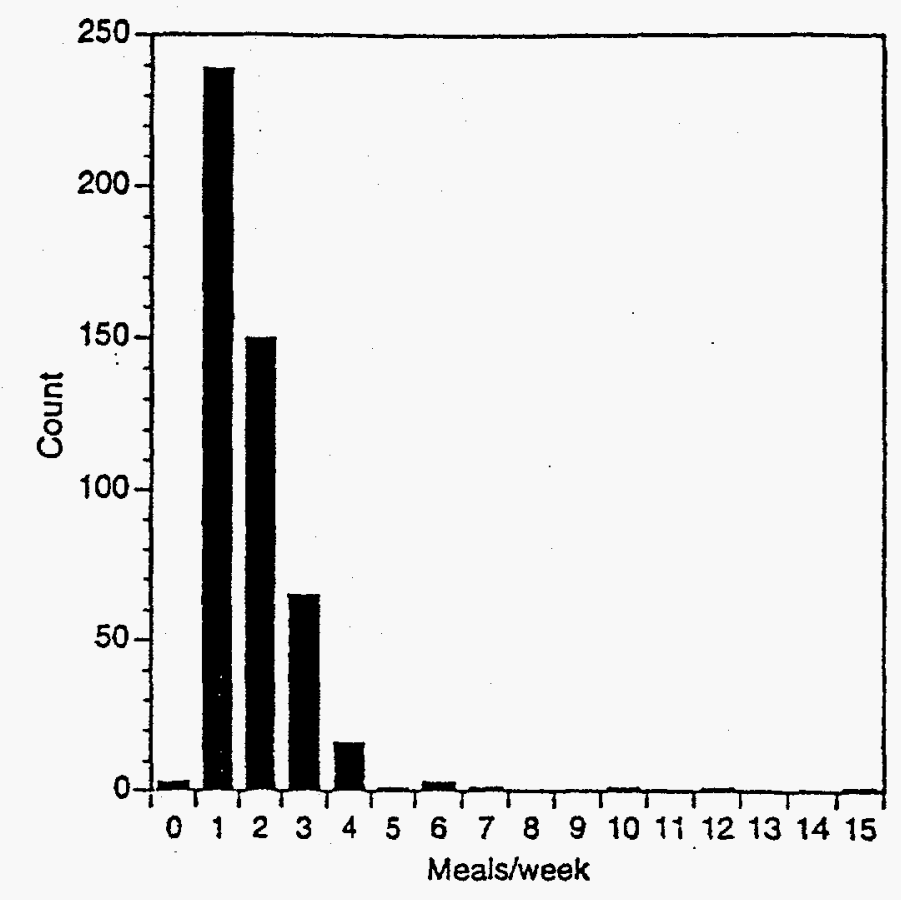

$I_{\text {fish }}=\frac{M \times M S}{7 d \times w_{e e k}^{-1}}$

where:

$l_{\text {fish }}=$ derived ingestion rate $(g / d)$.

$M=$ meals per week

MS = meal size (150 g/meal; USEPA, 1989a).

The resulting lognormal distribution (Table 4-3) was used to estimate exposures to recreational fishermen and their families. For some contaminants (lead in particular), the subpopulations with highest susceptibility to adverse health effects are infants and young children. USEPA (1990) reported data for intake rates of seafood by the population consuming seafood, obtained in a survey conducted over a period of one year (1973-1974). For juveniles (0-9 years of age), the rate of seafood ingestion was approximately $43 \%$ that of the general population. The intake rate distribution derived for recreational fishermen and their families was multiplied by a factor of 0.43 to estimate the rate of juvenile ingestion of fish (Table 4-3). 
Table 4-3. Derived lognormal intake distributions for fish caught near open bay platforms.

\begin{tabular}{|l|c|c|}
\hline \multirow{2}{*}{} & \multicolumn{2}{|c|}{ Intake (g/day) } \\
\cline { 2 - 3 } & $\begin{array}{c}\text { Recreational } \\
\text { Fishermen and } \\
\text { Families }\end{array}$ & Children \\
\hline mean & 38.4 & 16.6 \\
\hline median & 31.5 & 13.6 \\
\hline standard deviation & 26.4 & 11.6 \\
\hline minimum & 3.3 & 1.3 \\
\hline maximum & 228.6 & 115.7 \\
\hline 95th percentile & 89.5 & 38.5 \\
\hline
\end{tabular}




\section{CHARACTERIZATION OF CONTINUING DISCHARGES}

\subsection{Identification Of Continuing Discharges}

Louisiana regulations (Title 33 , March 20,1991 ) required the termination of all produced water discharges to natural or man-made water bodies located in intermediate, brackish or saline marsh areas after January 1,1995, unless the discharge (s) were authorized in an approved schedule for elimination or effluent limitation compliance. A variance through January, 1997 was granted (12/16/94) for permitted discharges located in open waters at least 1 mile from any shoreline in Chandeleur Sound, Breton Sound, Barataria Bay, Caminada Bay, Timbalier Bay, Terrebonne Bay, East Cote Blanche Bay, West Cote Blanche Bay or Vermillion Bay.

The Louisiana Department of Environmental Quality (LDEQ) identified produced water discharges in open bay areas (Table B-1 in Appendix B) that may qualify for this variance.

In August, 1994, a telephone survey of the operators was conducted to determine if they would take advantage of an extension of the phase-out rule for coastal Louisiana produced water discharges. Most operators indicated that they would continue to discharge through 1997 if allowed. Discharges that planned re-injection or had been shut in were not included in the current assessment (Table B-1, Appendix B). Some operators could not say what company policy would be if an extension were granted. These discharges were assumed to continue discharging, although they may have since been terminated. Therefore, the list of continuing open bay discharges used in the current assessment may include wells that are no longer active.

Figure 5-1 shows the locations of the assumed active discharges in open Louisiana bays. More detailed maps are given in Appendix B.

\subsection{Characterization Of Discharges}

\subsubsection{Data Sources}

Data describing the assumed continuing discharges listed in Table B-1 (Appendix B) and shown in Figure 5-1 were abstracted from LDEQ permit files. Table B-2 in Appendix B summarizes the data available for each discharge. A few permit files were not available. 
Figure 5-1. Assumed active discharges in open Louisiana bays.
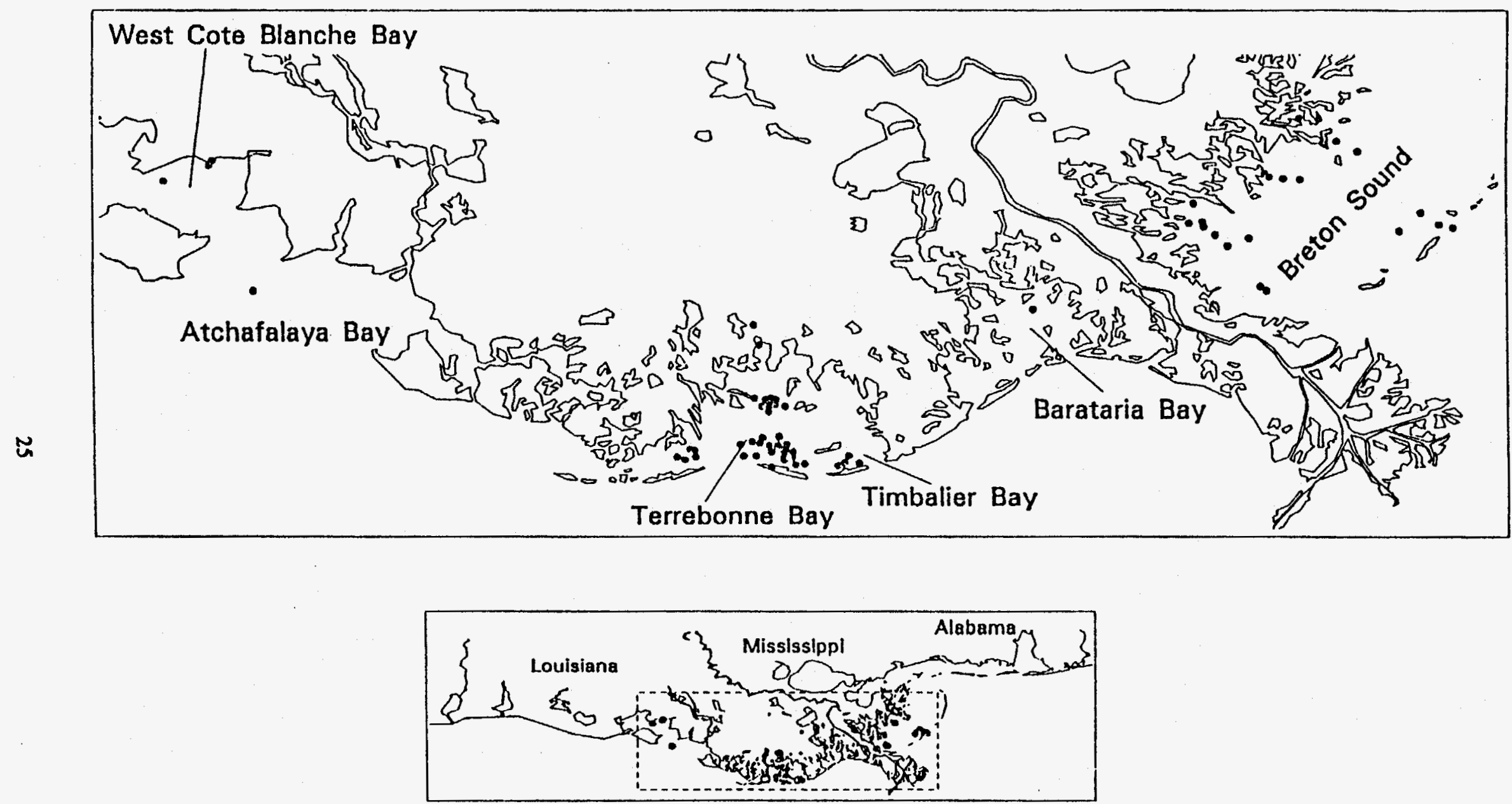


\subsubsection{Depths and Discharge Rates}

Information critical to an assessment of the environmental impact from a produced water discharge includes the depth of the platform and the rate of discharge. Higher rates of discharge in shallower waters can be expected to have more impact in terms of both human health and ecological effects than smaller discharges in deeper waters where dilution is greater.

Table 5-1 summarizes the data for platiorm depths and discharge rates. The total discharge rate data set is described in Table 5-1. High $(>5,000 \mathrm{bbl} / \mathrm{d})$ and low $(\leq 5,000 \mathrm{bbl} / \mathrm{d})$ discharge rates (Table 5-1) were described as lognormal distributions (Figure 5-2). Figure 5-3 shows the distribution of platform depths in the data set. Table B-2 in Appendix B gives the depth and discharge rate for each discharge point included in the analysis.

Table 5-1. Platform depths and discharge rates.

\begin{tabular}{|l|l|c|c|c|}
\hline & $\begin{array}{l}\text { Depth } \\
\text { (feet) }\end{array}$ & \multicolumn{3}{|c|}{ Discharge Rate (bbl/d) } \\
\cline { 2 - 5 } & & All discharges & $\leq \mathbf{5 , 0 0 0}$ & $>\mathbf{5 , 0 0 0}$ \\
\hline number & 29 & 62 & 46 & 16 \\
\hline mean & 9.1 & 4,527 & 999 & 13,865 \\
\hline standard deviation & 2.3 & 7,166 & 1,249 & 7,991 \\
\hline minimum & 4 & 1 & 1 & 5,364 \\
\hline maximum & 18 & $37,113$. & 4,914 & 37,113 \\
\hline
\end{tabular}

Note that the two coastal sites in the USDOE study are reasonably representative of these discharges, falling on the high end of the distribution for low discharge rates, and the low end of water depths $(2,000$ and $4,000 \mathrm{bbl} /$ day; 5 and 7.5 feet).

\subsubsection{Contaminants in the Effluent}

Chemical contaminants measured in open bay produced water discharges and reported in LDEQ permit files are summarized in Table 5-2. Data abstracted from LDEQ permit files for each discharge site are given in Appendix $B$, Table $B-$ 3. These data are for contaminants that were above the detection limit only, and overestimate the mean concentration in the data set.

Radium concentrations measured in the discharges are given in Table B-4 in Appendix B, and are summarized in Table 5-3. This data set suggests no clear relationship between ${ }^{226} \mathrm{Ra}$ and ${ }^{228} \mathrm{Ra}$ concentrations in the effluent (Figure 5-4). 
Figure 5-2. Lognormal Tests: discharge rates of continuing open bay discharges; $A, 1$ to 5,000 bbl/day $(r=0.8049) ; B,>5,000$ bbl/day $(r=0.9514)$.

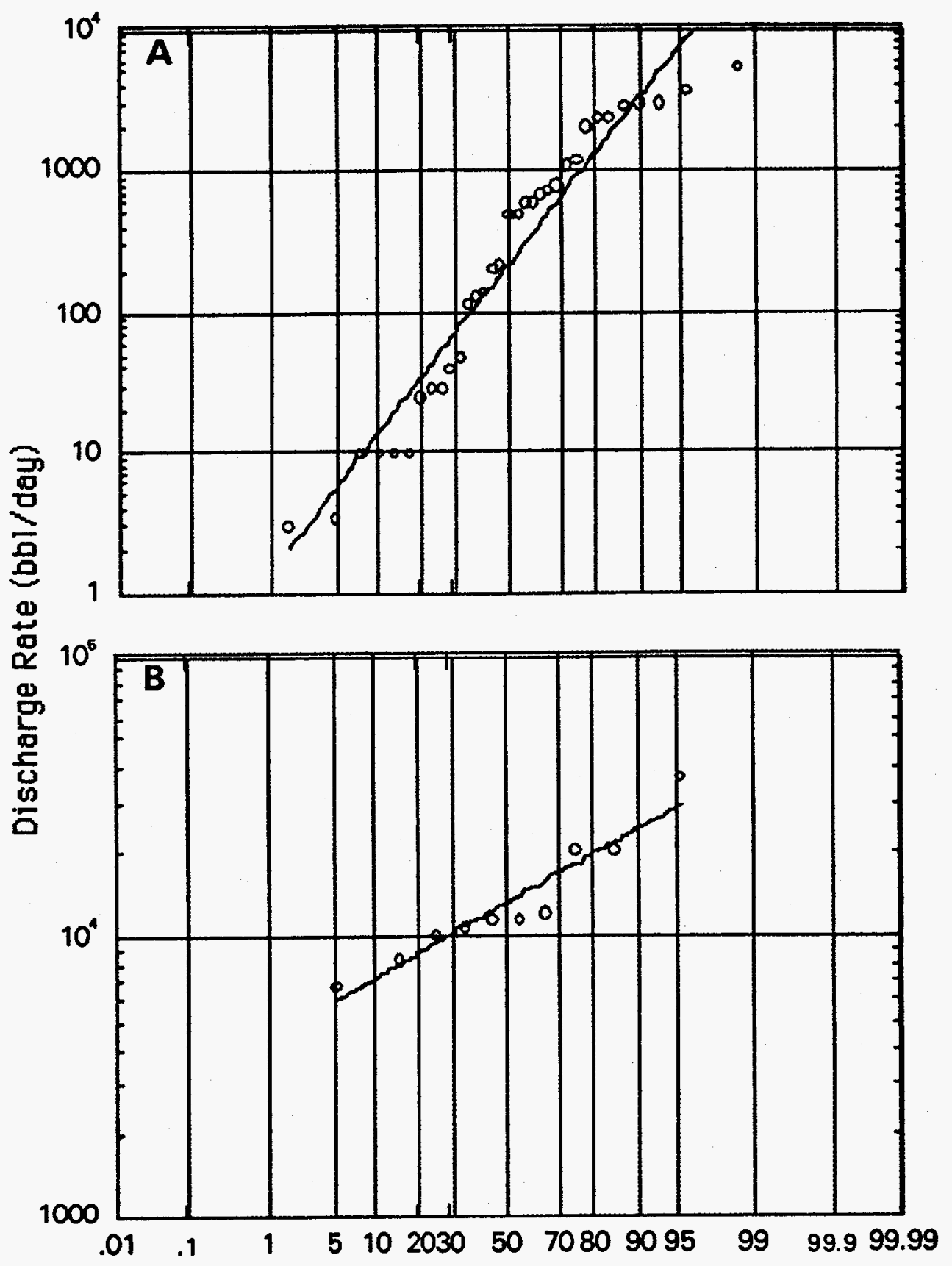


Figure 5-3. Depths of platforms, continuing open bay discharges.

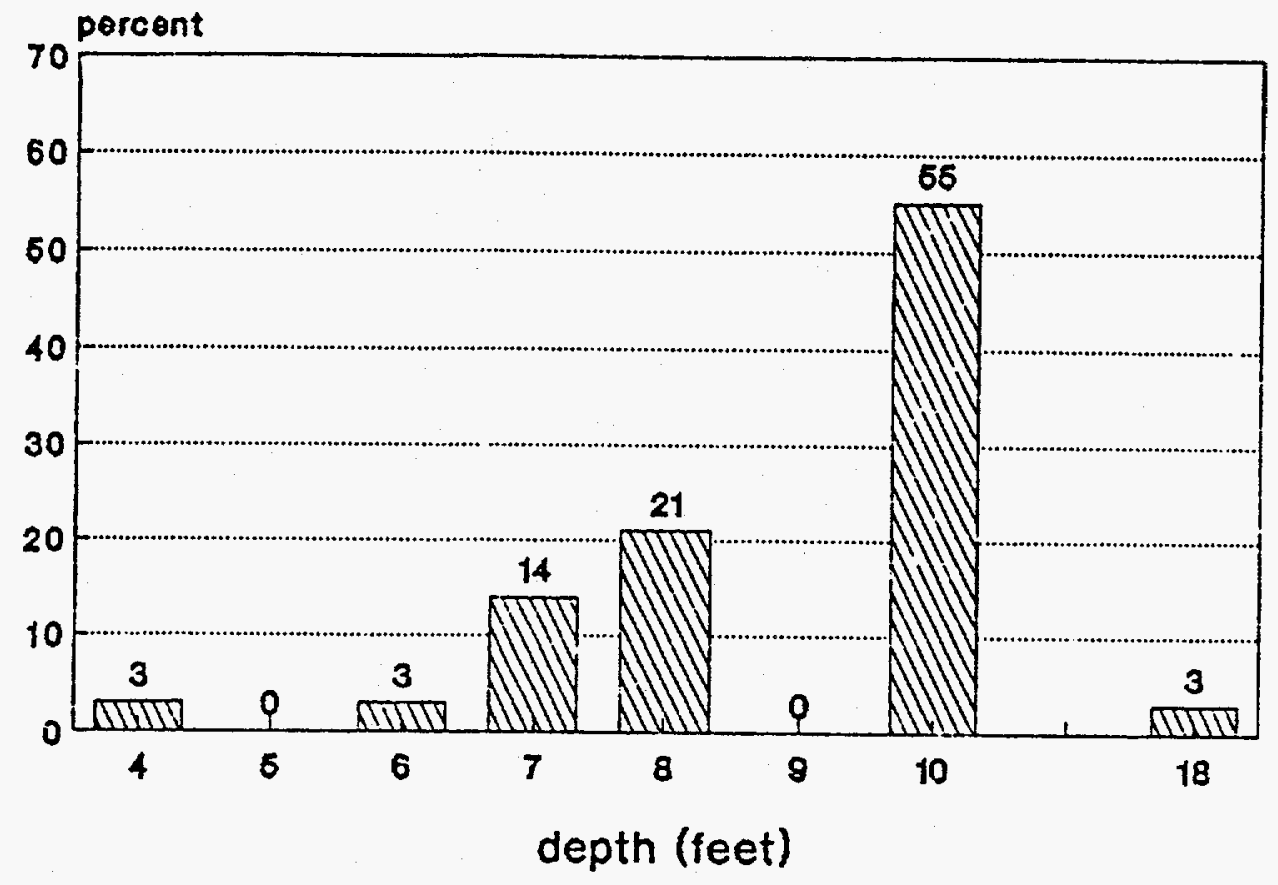

Table 5-2: Contaminant concentrations $(\mu \mathrm{g} / \mathrm{L})$ in open bay produced water discharges in Louisiana (for contaminants reported above detection limits).

\begin{tabular}{|l|c|c|c|c|c|}
\hline & count & minimum & maximum & mean & std dev \\
\hline METALS & & & & & \\
\hline Antimony & 7 & 11.85 & 20100 & 5595.91 & 8479.477 \\
\hline Arsenic & 11 & 6.9 & 498.5 & 74.74 & 136.76 \\
\hline Cadmium & 6 & 0.93 & 500 & 231.19 & 202.57 \\
\hline Chromium (VI) & 6 & 9.5 & 200 & 83.49 & 70.09 \\
\hline Copper & 11 & 10 & 710 & 288.37 & 197.93 \\
\hline Lead & 7 & 35.36 & 829000 & 104263 & 292839 \\
\hline Mercury & 4 & 0.007 & 27 & 7.08 & 11.26 \\
\hline Nickel & 7 & 57.90 & 2840 & 1013.86 & 1062.08 \\
\hline Selenium & 3 & 11.00 & 84 & 63.00 & 34.79 \\
\hline Silver & 5 & 11.30 & 400 & 143.32 & 160.09 \\
\hline Thallium & 4 & 248.39 & 3700 & 1904.74 & 1535.71 \\
\hline Zinc & 12 & 31.09 & 6375 & 1217.10 & 2102.65 \\
\hline & & & & & \\
\hline ORGANICS & & & & & \\
\hline Benzene & 12 & 10 & 9550 & 1813.23 & 2690.15 \\
\hline Bis (2-ethylhexyl) phthalate & 6 & 45 & 80 & 59.67 & 12.40 \\
\hline Naphthalene & 5 & 10 & 118 & 57.42 & 41.65 \\
\hline Phenol & 13 & 24 & 12000 & 1557.86 & 3144.72 \\
\hline Toluene & 12 & 16 & 2800 & 831.62 & 944.56 \\
\hline Xylenes & 9 & 7 & 862 & 183.30 & 265.84 \\
\hline
\end{tabular}


Table 5-3. Radium concentrations ( $\mathrm{pCi} / \mathrm{l})$ in open bay discharges.

\begin{tabular}{|l|c|c|}
\hline & ${ }^{226} \mathbf{R a}$ & ${ }^{228} \mathbf{R a}$ \\
\hline number & & 47 \\
\hline mean & 47 & 47.0 \\
\hline standard deviation & 191.4 & 250.0 \\
\hline minimum & 122.4 & 163.6 \\
\hline maximum & 0.0 & 0.0 \\
\hline
\end{tabular}

Figure 5-4. Relationship between ${ }^{226} \mathrm{Ra}$ and ${ }^{228} \mathrm{Ra}$ concentrations in effluents.

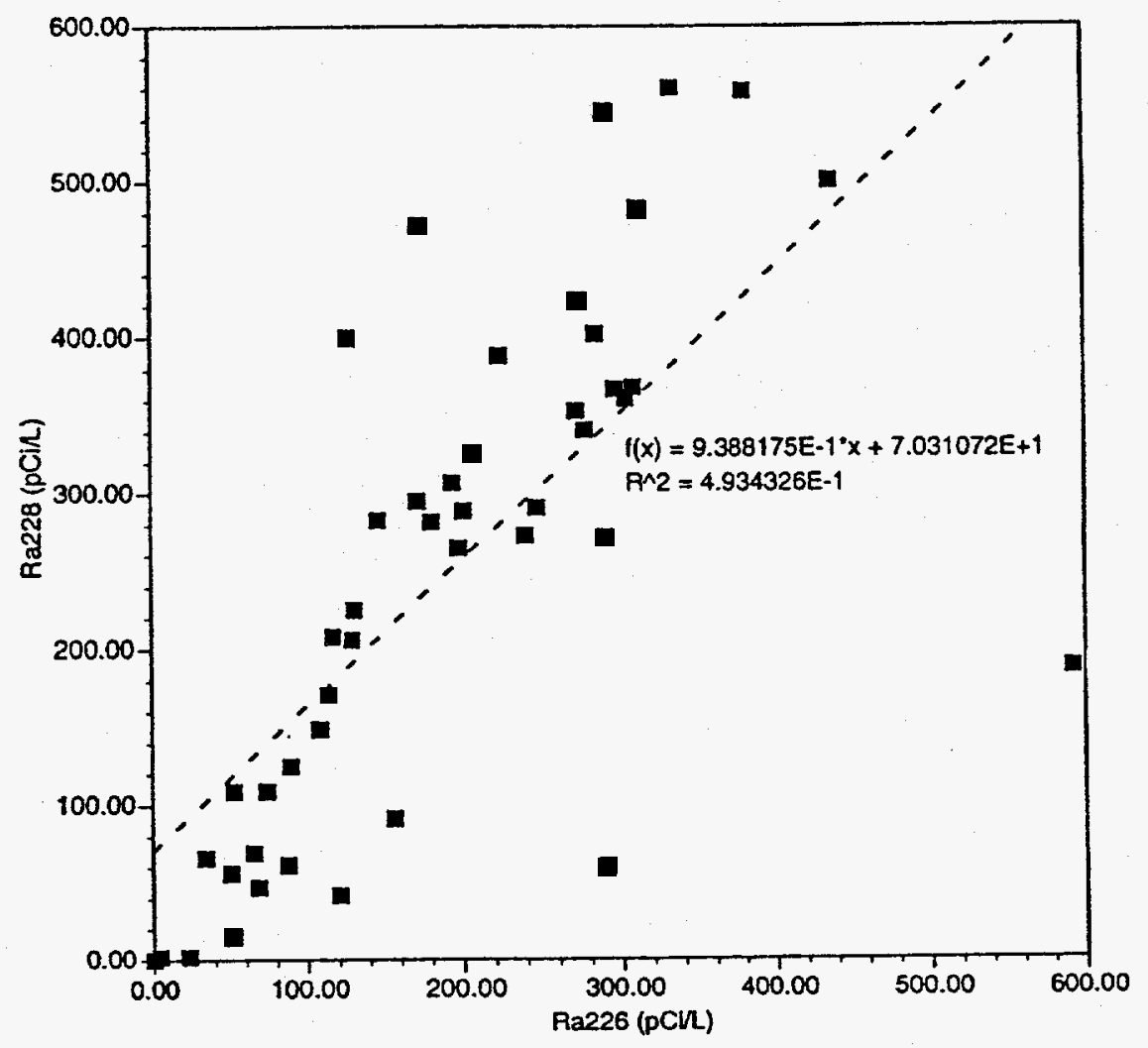




\subsubsection{Effluent Toxicity}

Toxicity tests are useful tools because they can directly measure potential aquatic effects. This is particularly true in the case of complex effluents, such as produced water, where a broad range of toxicants can be present at low levels.

Toxicity data were available in LDEQ permit files for 58 assumed continuing discharge sites. Data were available for acute toxicity tests $\left(96-\mathrm{hr} \mathrm{LC}_{50}\right)$ on $M$. bahia (an amphipod crustacean) and Cyprinodon variegatus (sheepshead minnow); 7-day chronic growth and survival NOEL tests on the same two species; and fecundity studies on $M$. bahia. The acute $L_{50}$ data and NOEL. growth and survival data are summarized in Tables 5-4 and 5-5.

Table 5-4. Results (percent effluent) of acute toxicity ( $\left(\mathrm{CC}_{50}\right)$ tests, Mysidopsis bahia and Cyprinodon variegatus.

\begin{tabular}{|l|c|c|}
\hline & Mysidopsis bahia & Cyprinodon variegatus \\
\hline & & \\
\hline $\mathbf{N}$ & 55 & 53 \\
\hline mean & 7.4 & 18.3 \\
\hline median & 4.8 & 15.7 \\
\hline standard deviation & 4.9 & 9.2 \\
\hline minimum & 0.07 & 2.4 \\
\hline maximum & 17.8 & 54.3 \\
\hline
\end{tabular}

Table 5-5. Results (NOEL, growth and survival, percent effluent) of chronic toxicity tests.

\begin{tabular}{|l|c|c|c|c|}
\hline & \multicolumn{2}{|c|}{ Mysidopsis bahia } & \multicolumn{2}{c|}{ Cyprindon variegatus } \\
\hline & survival & growth & survival & growth \\
\hline & & & & \\
\hline $\mathrm{N}$ & 58 & 58 & 56 & 55 \\
\hline mean & 2.9 & 3.7 & 6.0 & 7.0 \\
\hline median & 1.4 & 1.9 & 3.4 & 4.2 \\
\hline standard deviation & 3.1 & 3.6 & 5.6 & 5.9 \\
\hline minimum & 0.04 & 0.07 & 0.14 & 0.15 \\
\hline maximum & 11.4 & 14.2 & 19.1 & 22.7 \\
\hline
\end{tabular}




\subsection{Transport Modeling}

The USEPA surface water transport model CORMIX 2.1 (Cornell Mixing Zone Expert System Model; Doneker and Jirka, 1990) was used to estimate the dilution expected at 50 and 200 feet from open bay discharges. The CORMIX model may be used for the prediction of aqueous toxic or conventional pollutant discharges to surface water bodies. Its major emphasis is on prediction of plume geometry and dilution within an initial mixing zone, but the model also predicts plume behavior at larger distances (Bouchard et al., 1995). The current version allows simulation of submerged or surface, single and multiport discharges. CORMIX has been used by USEPA in rulemaking for produced water discharges.

Table 5-6 summarizes the input parameters used in the analysis. A depth of 8 feet $(2.44 \mathrm{~m})$ was chosen to represent the assumed continuing open bay discharges in Louisiana (see Figure 5-3). A range of discharge rates was modeled (Table 5-7) to cover the range of discharge rates for the open bay discharges (see Figure 5-2).

Because of the shallow depth, the model was run using an unstratified scenario with a surface and bottom water density of $1005 \mathrm{~kg} / \mathrm{m}^{3}$. These values were derived from temperature and salinity data published in literature reviewed by USEPA (USEPA, 1995a). A produced water discharge density of $1020 \mathrm{~kg} / \mathrm{m}^{3}$ was derived from USEPA's review of produced water effluent density estimates, and an ambient velocity of $0.05 \mathrm{~m} / \mathrm{s}$ was used (USEPA, 1995a).

CORMIX forces a submerged single port discharge to be in the bottom $1 / 3$ of the water column. The model was run with the discharge pipe pointing straight up from the lower $1 / 3$ of the water column. This is unrealistic for produced water discharges, because they are normally released on or close to the surface. Our decision to run the model with this discrepancy was based on the assumption that differences in dilution rates resulting from a discharge pointing up at the surface or down toward the bottom in a shallow bay environment would be negligible.

To test this assumption, sensitivity runs using altered input parameters were run to "fool" the model into simulating a more accurate scenario. The model can be adjusted to make the projections more accurate by creating a mirror image using a stratified water column and inverting the ambient densities (Avanti Corporation, 1993). Specifically, the depth was lowered from $2.44 \mathrm{~m}$ to $3.44 \mathrm{~m}$, the discharge pipe was placed at $2.44 \mathrm{~m}$ with the theta angle at $90^{\circ}$, pointing straight up (i.e., a mirror image of effluent being discharged directly onto the surface). To complete this mirror imaging, the effluent had to be changed from a negatively buoyant plume (i.e., surface to bottom) to one with a positive buoyancy. The water column data was modeled as stratified with surface 
density at $1018 \mathrm{~kg} / \mathrm{mg}^{3}$ and the bottom density at $1020.15 \mathrm{~kg} / \mathrm{mg}^{3}$. The discharge density was then reduced to $970 \mathrm{~km} / \mathrm{m}^{3}$. The resulting scenario was modeling a plume traveling the entire depth of the receiving environment from the bottom to the surface, simulating the same characteristics as a surface discharge of a negatively buoyant effluent. Results of this sensitivity analysis indicated that differences in predicted dilution rates are negligible. The dilution factor for a worst case scenario of $37,500 \mathrm{bbl} /$ day discharge at $200 \mathrm{ft}$ is 13.8 as opposed to 12.0 for the unaltered input parameters.

Table 5-6. CORMIX input parameters.

\begin{tabular}{|l|l|}
\hline AMBIENT PARAMETERS & \\
\hline & \\
\hline cross section & unbounded \\
\hline average depth & $2.44 \mathrm{~m}$ \\
\hline depth at discharge & $2.44 \mathrm{~m}$ \\
\hline ambient velocity & $0.05 \mathrm{~m} / \mathrm{s}$ \\
\hline Darcy-Weisbach friction factor & 0.0524 \\
\hline Manning's friction factor & 0.03 \\
\hline wind velocity & $2 \mathrm{~m} / \mathrm{s}$ \\
\hline stratification type & unstratified \\
\hline surface density & $1005 \mathrm{~kg} / \mathrm{m}^{3}$ \\
\hline bottom density & $1005 \mathrm{~kg} / \mathrm{m}^{3}$ \\
\hline & \\
\hline DISCHARGE PARAMETERS & \\
\hline & \\
\hline discharge description & submerged single port \\
\hline nearest bank & $1 \mathrm{eft}$ \\
\hline distance to bank & $1609.76 \mathrm{~m}$ \\
\hline port diameter & $0.127 \mathrm{~m}$ \\
\hline port cross-section area & $0.0126 \mathrm{~m}^{2}$ \\
\hline discharge flow rate & $100-37,500$ bbl/day \\
\hline discharge port height & $0.8 \mathrm{~m}$ \\
\hline vertical discharge angle & $90 \mathrm{degrees}$ \\
\hline horizontal discharge angle & $0 \mathrm{degrees}$ \\
\hline discharge density & $1020 \mathrm{~kg} / \mathrm{m}^{3}$ \\
\hline density difference & $-15 \mathrm{~kg} / \mathrm{m}^{3}$ \\
\hline buoyant acceleration & $-0.1464 \mathrm{~m} / \mathrm{s}^{2}$ \\
\hline discharge concentration & $100 \mathrm{percent}$ \\
\hline surface heat exchange coeff. & $0 \mathrm{~m} / \mathrm{s}$ \\
\hline coefficient of decay & $0 \mathrm{~m} / \mathrm{s}$ \\
\hline & \\
\hline
\end{tabular}


CORMIX uses a 13 step procedure to determine the flow category of a discharge. CORMIX classified the flow as "NV5" for discharge rates between $7,500 \mathrm{bbl} /$ day and $37,500 \mathrm{bbl} /$ day, and as "NV2" for discharge rates up to 5000 $\mathrm{bbl/day.} \mathrm{Both} \mathrm{of} \mathrm{these} \mathrm{classifications} \mathrm{show} \mathrm{that} \mathrm{the} \mathrm{model} \mathrm{treated} \mathrm{the} \mathrm{discharge}$ as a negatively buoyant discharge in a uniform ambient layer. Class NV2 has an extremely strong negative buoyancy causing upstream spreading and does not have layer or surface interaction. Class NV5 has an interaction and unstable discharge configuration with vertical mixing and recirculation zones. After determining the flow classification CORMIX selects an algorithm that best represents the discharge scenario (Doneker and Jirka, 1990). The NV5 algorithm did not predict dilutions at 50 feet from the discharge.

Results are presented in terms of the expected dilution factor in the plume at 50 and 200 feet (Table 5-7) where :

DF (dilution factor) $=$ Concentration in Effluent $/$ Concentration in Water

These data (Table 5-7) were used to derive empirical relationships between discharge rates and dilution factors (Figure 5-5):

For discharge rates $\leq 5000 \mathrm{bbl} / \mathrm{d}$

$$
\begin{array}{ll}
\mathrm{DF}_{50 \pi}=10633^{*}(\text { DISCHARGE})^{-0.867} & (\mathrm{R}=0.997) \\
\mathrm{DF}_{200 \pi}=46303^{*}(\mathrm{DISCHARGE})^{-0.946} & (\mathrm{R}=0.9997)
\end{array}
$$

For discharge rates $>5000 \mathrm{bbl} / \mathrm{d}$

$$
\mathrm{DF}_{200 \mathrm{ft}}=36061{ }^{*}(\mathrm{DISCHARGE})^{-0.762} \quad(\mathrm{R}=0.9997)
$$

In modeling the dilution factors at $200 \mathrm{ft}, \mathrm{CORMIX}$ automatically switched from the NV2 to the NV5 algorithm, at release rates greater than $5000 \mathrm{bbl/d}$. Table 57 shows that there is a $100 \%$ increase in $\mathrm{DF}_{200} \mathrm{ft}$ in the transition from 5000 $\mathrm{bbl} / \mathrm{d}$ to $7500 \mathrm{bbl} / \mathrm{d}$. The $\mathrm{DF}_{200 \mathrm{ft}}$ derived from hypothetical release rates between $>5000$ and $<7500 \mathrm{bbl} / \mathrm{d}$ were not a good fit to the empirical relationship derived from the NV5 algorithm results. An attempt to fit these release rates to the relationship derived from the NV2 algorithm also yielded a poor fit. Only three of the assumed continuing open bay discharges (Appendix B, Table B-2) fell into this transition ( $5365 \mathrm{bbl} / \mathrm{d} ; 6800 \mathrm{bbl} / \mathrm{d}, 7368 \mathrm{bbl} / \mathrm{d})$. In the risk analysis, we opted to use $\mathrm{DF}_{200 \mathrm{ft}}$ values derived by the NV5 algorithm for these discharges, with the assumption that any overestimates of dilution would be offset by the conservatism of the CORMIX model. 
Table 5-7. Estimates of dilution factors in the plume and at 50 and 200 feet.

\begin{tabular}{|c|c|c|c|}
\hline \multirow{2}{*}{$\begin{array}{c}\text { Discharge Rate } \\
\text { (bbl/d) } \\
\end{array}$} & \multicolumn{2}{|c|}{ Dilution Factor } & \multirow{2}{*}{$\begin{array}{c}\text { CORMIX Flow } \\
\text { Class }\end{array}$} \\
\hline & 50 feet $^{1}$ & 200 feet & \\
\hline 1 & 14661 & 33539 & NV2 \\
\hline 3 & 6561.6 & 76824 & NV2 \\
\hline 5 & 3514.6 & 22471 & NV2 \\
\hline 10 & 2385.5 & 10016 & NV2 \\
\hline 25 & 771.30 & 6294.3 & NV2 \\
\hline 50 & 350 & 3002.7 & NV2 \\
\hline 100 & 168.3 & 1135.5 & NV2 \\
\hline 200 & 85.2 & 435.4 & NV2 \\
\hline 500 & 36.0 & 127.5 & NV2 \\
\hline 1000 & 19.7 & 53.4 & NV2 \\
\hline 2000 & 11.4 & 24.4 & NV2 \\
\hline 3000 & 9.4 & 17.3 & NV2 \\
\hline 4000 & 11.2 & 17.9 & NV2 \\
\hline 5000 & 13.0 & 19.1 & NV2 \\
\hline 7500 & - & 41.0 & NV5 \\
\hline 10000 & - & 32.3 & NV5 \\
\hline 12500 & - & 27.1 & NV5 \\
\hline 15000 & - & 23.5 & NV5 \\
\hline 22500 & - & 17.3 & NV5 \\
\hline 37500 & - & 12.0 & NV5 \\
\hline & & & \\
\hline
\end{tabular}

NV5 does not predict a dilution factor at 50 feet.

While low discharge rates ( 1 and $3 \mathrm{bbl} / \mathrm{d}$ ) yielded good fits to the empirical relationship derived for $D_{50} \mathrm{ft}$, they yielded poor fits to relationship derived for $\mathrm{DF}_{200 \mathrm{n}}$. Therefore, $\mathrm{DF}_{200 \mathrm{ft}}$ for 1 and $3 \mathrm{bbl} / \mathrm{d}$ was calculated using the relationship derived for 5 to $5000 \mathrm{bbl} / \mathrm{d}$.

The empirical relationships were applied to the distribution of discharge rates for the open bay discharges (Table 5-1) to produce a distribution of dilution factors for 50 and 200 feet (Table 5-8). The dilution factor distributions were also used to develop a distribution of percent effluent expected in the water column at 50 and 200 feet (Table 5-8). 
Table 5-8. Dilution factors and effluent concentrations (percent effluent) in the plume, calculated by CORMIX for open bay discharges.

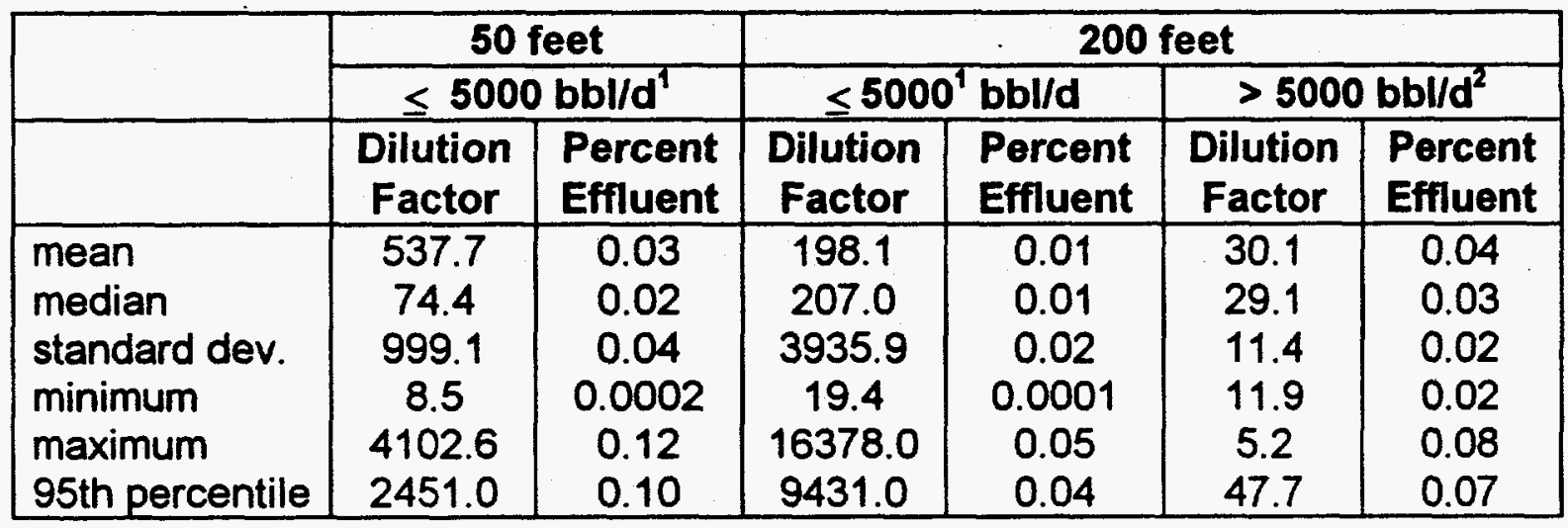

2NV2 algorithm for 1 to $5000 \mathrm{bbl} / \mathrm{day}$

1 NV5 algorithm for $>5000$ bbl/day yielded results only at 200 feet 
Figure 5-5. Relationships between discharge rates and model-derived dilution factors in the plume at 50 and 200 feet from discharge: A and B, NV2 algorithms; C, NV5 algorithm.
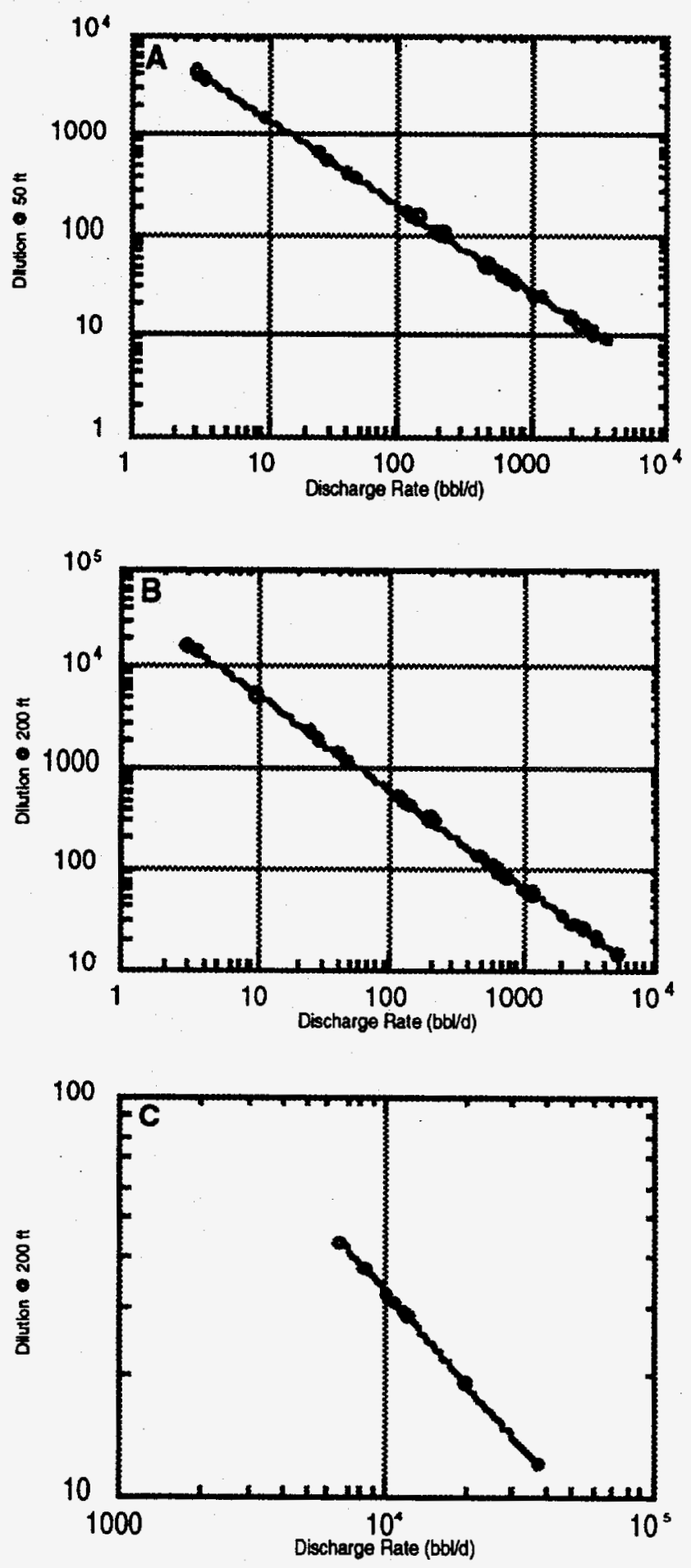


\section{HUMAN HEALTH RISK ASSESSMENT FOR RADIUM}

\subsection{Introduction and Approach}

Radium may be accumulated by aquatic organisms, and there is a potential human health risk associated with the ingestion of radium in fish and shellfish caught near open bay produced water discharges. Screening and quantitative probabilistic human health risk assessments were done for open-bay radium discharges in Louisiana.

The two data sets used in this risk assessment were:

- measured concentrations of ${ }^{226} \mathrm{Ra}$, and ${ }^{228} \mathrm{Ra}$ in finfish and crustaceans $(\mathrm{pCi} / \mathrm{g}$ ) caught near the discharge at the Delacroix Island and Bay de Chene study sites (pre-termination data; section 4); and

- measured concentrations of ${ }^{226} \mathrm{Ra}$ and ${ }^{228} \mathrm{Ra}$ in 47 continuing open bay discharges (pCill, section 5).

\subsection{Screening Assessment}

\subsubsection{Concentrations in Edible Seafood}

\section{Biota Near USDOE Open Bay Study Sites}

Biota were collected in Spring 1993 from two USDOE study platform locations (Delacroix Island, Bay de Chene) and two reference stations for each platform. Screening assessments were done on radium measured in these biota.

Only one value for each isotope was available for each species sampled from each site at Delacroix Island (Table 6-1). For each isotope in each species, the value of the concentration at the discharge site and the higher of the two reference site values were used in the screening analysis. Multiple samples were taken for each species in the study at Bay de Chene. The highest concentrations of radium detected in each species at each site (Table 6-1) were used in the screening analysis. 
Table 6-1. Maximum radium concentrations measured in biota at Delacroix Island and Bay de Chene Study Sites (pCi/g).

\begin{tabular}{|c|c|c|c|c|c|c|c|c|}
\hline \multicolumn{5}{|c|}{ Delacroix Island } & \multicolumn{4}{|c|}{ Bay de Chene } \\
\hline & \multicolumn{2}{|c|}{ Discharge } & \multicolumn{2}{|c|}{ Reference } & \multicolumn{2}{|c|}{ Discharge } & \multicolumn{2}{|c|}{ Reference } \\
\hline & ${ }^{2266} \mathrm{Ra}$ & ${ }^{22 x} \mathbf{R a}$ & ${ }^{226} \mathrm{Ra}$ & ${ }^{223} \mathbf{R a}$ & ${ }^{226} \mathbf{R a}$ & ${ }^{220} \mathrm{Ra}$ & ${ }^{246} \mathrm{Ra}$ & ${ }^{228} \mathbf{R a}$ \\
\hline croaker & 0.005 & 0.112 & 0.063 & $\overline{0.021}$ & 0.024 & 0.094 & 0.032 & 0.05 \\
\hline spot & 0.002 & 0.076 & 0.002 & 0.107 & 0.034 & 0.086 & 0.029 & 0.01 \\
\hline sea trout & NS & NS & NS & NS & 0.021 & 0.159 & 0.016 & 0.042 \\
\hline blue crab & 0.025 & 0.09 & 0.012 & 0.046 & 0.023 & 0.059 & 0.024 & 0.01 \\
\hline shrimp & NS & NS & NS & NS & 0.011 & 0.01 & 0.027 & 0.124 \\
\hline
\end{tabular}

NS $=$ no sample

\section{Fish Near Continuing Discharges}

Mean and maximum radium concentrations from the data set for continuing open bay discharges were used to estimate water concentrations in the plume at 200 feet (Table 6-2). A conservative dilution factor of 20 was chosen to estimate worst-case water concentrations. A dilution factor of 20 was chosen to estimate worst-case concentrations because it yields more conservative concentrations than those predicted by the CORMIX model (section 5) at 50 and 200 feet from the discharge. A conservative bioaccumulation factor of 100 (IAEA, 1982) was used to calculate concentrations of radium in edible fish:

$$
C F=(B A F \times C W) \times \frac{1 l}{1,000 g}
$$

where:

$\mathrm{CF}=$ radium concentration in fish $(\mathrm{pCi} / \mathrm{g})$

$\mathrm{BAF}=$ bioaccumulation factor $(100)$

$\mathrm{CW}=$ radium concentration in water $(\mathrm{pCi} / \mathrm{l})$

Estimated concentrations in edible fish for mean and maximum radium discharge concentrations are given in Table 6-2. The estimated concentrations in fish (Table 6-2) are based on a series of conservative models and assumptions and are significantly higher than radium concentrations measured in field studies (e.g. Table 6-1).

\subsubsection{Exposure Assessment}

The screening analyses used a conservative value of 70 years as the exposure period. A conservative ingestion rate of $132 \mathrm{~g} / \mathrm{d}$ was used (USEPA 1989a; 95th percentile value). Exposure was calculated for ${ }^{226} \mathrm{Ra}$ and ${ }^{228} \mathrm{Ra}$ separately as: 
$I_{R a}=I_{\text {fish }} \times[R a]_{\text {fishes }}$

where:

$I_{R_{a}}=$ radium intake rate $(\mathrm{pCi} / \mathrm{d})$

$\mathrm{I}_{\text {fish }}=$ intake rate of fish $(132 \mathrm{~g} / \mathrm{d})$

$[R a]_{\text {hehes }}=$ concentration of radium in fishes $(\mathrm{pCi} / \mathrm{g})$

Table 6-2. Screening analysis; estimated water and fish concentrations 200 feet from continuing open bay discharges.

\begin{tabular}{|l|c|c|c|}
\hline & $\begin{array}{c}\text { Effluent } \\
\text { (pCi/l) }\end{array}$ & $\begin{array}{c}\text { Water } \\
\text { (pCi//) }\end{array}$ & $\begin{array}{c}\text { Fish } \\
\text { (pCi/g) }\end{array}$ \\
\hline mean & & & 1.0 \\
\hline maximum & 191.4 & 9.6 & 3.0 \\
\hline & 592 & 29.6 & \\
\hline${ }^{203}$ Ra & & & 1.3 \\
\hline mean & & & 2.8 \\
\hline maximum & 250 & 12.5 & 28 \\
\hline
\end{tabular}

\subsubsection{Dose-response Assessment}

USEPA (Federal Register, 1991) uses risk factors of $4.4 \times 10^{-6}$ for ${ }^{226} \mathrm{Ra}$ and $3.8 \times 10^{-6}$ for ${ }^{228} \mathrm{Ra}$ (individual lifetime fatal cancer risk per $\mathrm{pCl} / /$ of drinking water), assuming an intake rate of $2 \mathrm{l} / \mathrm{d}$ of drinking water. These risk factors can be converted to units of individual lifetime fatal cancer risk per $\mathrm{pCi/d}$ by dividing by 2 , resulting in unit risk factors of $2.2 \times 10^{-6}$ for ${ }^{226} \mathrm{Ra}$ and $1.9 \times 10^{-6}$ for ${ }^{228} \mathrm{Ra}$ (per $\mathrm{pCi} / \mathrm{d}$ ). These unit risk factors were used in the screening analyses.

\subsubsection{Risk Characterization}

Individual lifetime fatal cancer risks were calculated separately for ${ }^{226} \mathrm{Ra}$ and ${ }^{228} \mathrm{Ra}$ and then summed. Individual lifetime risk of cancer mortality (IR) was calculated as:

$I L R=I_{R a} \times R F$

where:

ILR = individual incremental lifetime fatal cancer risk

$I_{R_{a}}=$ radium intake rate $(\mathrm{pCi} / \mathrm{d})$

$\mathrm{RF}=$ risk factor (risk per $\mathrm{pCi} / \mathrm{d}, 70$ year exposure period) 


\subsubsection{Results}

Results of the screening risk assessments for radium measured at the Delacroix Island and Bay de Chene study sites, and for the continuing open bay discharges are given in Table 6-3.

Table 6-3. Screening human health risk assessment for Delacroix Island and Bay de Chene study sites, and modeled continuing discharges; individual lifetime fatal cancer risk.

\begin{tabular}{|l|l|l|l|l|l|l|}
\hline & \multicolumn{2}{|c|}{ Delacroix Island } & \multicolumn{2}{c|}{ Bay de Chene } & \multicolumn{2}{c|}{ Modeled Discharges } \\
\hline Species & Discharge & Reference & Discharge & Reference & Mean & Maximum \\
\hline & & & & & & \\
\hline croaker & $1.7 \times 10^{-5}$ & $7.5 \times 10^{-5}$ & $3.1 \times 10^{-5}$ & $2.2 \times 10^{-5}$ & - & - \\
\hline spot & $8.2 \times 10^{-6}$ & $8.2 \times 10^{-6}$ & $3.1 \times 10^{-5}$ & $1.1 \times 10^{-5}$ & - & - \\
\hline sea trout & NS & NS & $4.6 \times 10^{-5}$ & $1.5 \times 10^{-5}$ & - & - \\
\hline blue crab & $1.2 \times 10^{-5}$ & $1.5 \times 10^{-5}$ & $2.2 \times 10^{-5}$ & $9.5 \times 10^{-6}$ & -- & -- \\
\hline shrimp & NS & NS & $5.7 \times 10^{-6}$ & $3.9 \times 10^{-5}$ & - & -- \\
\hline & & & & & & \\
\hline fish & - & - & - & -- & $6.2 \times 10^{-4}$ & $1.6 \times 10^{-3}$ \\
\hline
\end{tabular}

NS=no sample

Estimated risks in the screening analysis for the ingestion of radium in fishes exceed $1 \times 10^{-6}$ in all cases. Note that estimated cancer risks from eating seafood sampled at reference stations at Delacroix Island and Bay de Chene are similar to those for ingestion of seafood caught near the discharges (pretermination).

For the modeled continuing discharges, maximum predicted risks are greater than $1 \times 10^{-3}$. These results do nor represent reasonable estimates of risk because of the conservative nature of the screening level assessment, suggesting a need for a more detailed, probabilistic assessment. This quantitative assessment is presented in the following section.

\subsection{Probabilistic Assessment}

\subsubsection{Exposure Assessment}

\subsubsection{Concentrations in Edible Fish}

\section{USDOE Open Bay Sites}

Preliminary data on concentrations of radium in muscle from fishes sampled at the discharge sites were assumed to conservatively represent the concentrations in edible flesh of all fishes caught by recreational fishermen. 
Distributions for radium concentrations in finfish at Delacroix Island and Bay de Chene were derived for the probabilistic human health risk assessment. At Delacroix Island, only one fish of each of the same three species was sampled. Therefore the concentrations $(\mathrm{pCi} / \mathrm{g})$ of ${ }^{226} \mathrm{Ra}(0.02,0.03,0.03)$ and the concentrations of ${ }^{228} \mathrm{Ra}(0.04,0.04,0.29)$ were used to represent the concentration of radium in fish, with equal probabilities for the values from the three species.

For the three species of finfish sampled (croaker spot and seatrout) at the Bay de Chene discharge, the range of all values of ${ }^{226} \mathrm{Ra}$ in muscle could not be distinguished from a normal distribution ${ }_{226}$ while those for ${ }^{228} \mathrm{Ra}$ fit a lognormal distribution. The combined values for ${ }^{226} \mathrm{Ra}$ concentrations were assumed to be a truncated normal distribution; averaging $0.017 \mathrm{pCi} / \mathrm{g}$ (range, 0.003 to 0.027 ). For ${ }^{228} \mathrm{Ra}$ the combined values were assumed to be a lognormal distribution averaging $0.067 \mathrm{pCi} / \mathrm{g}$ (range, 0.009 to 0.096 ).

\section{Continuing Discharges}

Radium concentrations in edible fish were estimated for an assumed continuation of open bay discharges in Louisiana in two steps.

In the first step, the distribution of radium water concentrations in the plume was estimated by modifying the distribution of ${ }^{226} \mathrm{Ra}$ and ${ }^{228} \mathrm{Ra}$ concentrations reported for the open bay discharges (Table 5-3) by a distribution of dilution factors derived for the plume at 200 feet using the CORMIX model (section 5; Table 5-8).

Radium concentrations in fish (in the plume at 200 feet) were then derived applying the bioaccumulation factor method in equation (6.1).

A BAF distribution based on data collected in coastal Louisiana (Meinhold and Hamilton, 1992) was used to estimate radium concentrations in fish. This distribution is lognormal, has a range of 2 to 100 , a mean of 30.4 and a standard deviation of 28. Table 6-4 gives the estimated distributions for radium concentrations in fish. These values over-estimate the concentration of radium in fish near open bay platforms because they use concentrations predicted in the plume, not average concentration in the water column. 
Table 6-4. Estimated radium concentrations in water and fish in modeled plumes 200 feet from open bay discharges.

\begin{tabular}{|l|c|c|c|c|}
\hline & \multicolumn{2}{|c|}{ Water Concentration (pCi/l) } & \multicolumn{2}{|c|}{ Fish Concentration (pCi/g) } \\
\hline & ${ }^{226} \mathrm{Ra}$ & $220 \mathrm{Ra}$ & ${ }^{206} \mathrm{Ra}$ & ${ }^{26} \mathrm{Ra}$ \\
\hline mean & $5.7 \times 10^{-1}$ & $6.8 \times 10^{-1}$ & $1.5 \times 10^{-2}$ & $1.9 \times 10^{-2}$ \\
\hline median & $2.4 \times 10^{-1}$ & $3.0 \times 10^{-7}$ & $5.1 \times 10^{-3}$ & $6.6 \times 10^{-3}$ \\
\hline std. dev & 1.1 & 1.1 & $3.3 \times 10^{-2}$ & $4.0 \times 10^{-2}$ \\
\hline minimum & $6.3 \times 10^{-3}$ & $8.4 \times 10^{-3}$ & $3.4 \times 10^{-5}$ & $4.9 \times 10^{-5}$ \\
\hline maximum & 15 & 13 & $4.6 \times 10^{-1}$ & $6.0 \times 10^{-1}$ \\
\hline 95th percentile & 2.0 & 2.3 & $6.1 \times 10^{-2}$ & $7.5 \times 10^{-2}$ \\
\hline
\end{tabular}

Fish Away From Platforms

For comparison, risks from ingestion of fish caught away from platforms in the Gulf of Mexico were estimated. Radium concentrations in fish not associated with platforms were assumed to be uniformly distributed, with a range of 0 to $0.01 \mathrm{pCi} / \mathrm{g}$ (Meinhold et al., 1995).

\subsubsection{Ingestion Rates}

Ingestion rates for recreational fishermen and their families were derived in section 4.3.2. The derived distribution of intake rates was lognormal, had a mean value of $38.4 \mathrm{~g} / \mathrm{d}$, a median value of 31.5 , a standard deviation of 26.4 and a 95th percentile value of 89.5 .

\subsubsection{Exposure Period}

Exposure periods (i.e. number of years fishermen catches and eats fish close to a open bay produced water discharge) may vary from several years to a large part of a lifetime. The probabilistic risk assessment assumed that the exposure period for recreational fishermen ranged from 5 to 65 years, and was described by a triangular distribution with the most frequent value set at 20 years.

\subsubsection{Calculation of Radium Exposure}

Daily ${ }^{226} \mathrm{Ra}$ and ${ }^{228} \mathrm{Ra}$ ingestion rates during the exposure period were calculated by using the distributions described above, in equation (6.2).

\subsubsection{Dose Response Assessment}

Current practice in radiation protection is to assume there is a cancer risk associated with even small doses of radiation. Risk factors are derived from epidemiological data and extrapolated down to low doses to describe the cancer risk associated with small exposures. Appendix $C$ summarizes the basic concepts in radiation protection applicable to risk assessment, discusses in 
detail the USEPA risk factors for radium and derives the distribution for the cancer mortality risk factors used in the probabilistic assessment presented here (Table 6-5).

Table 6-5. Risk factor distribution for ${ }^{226} \mathrm{Ra}$ and ${ }^{228} \mathrm{Ra}$ (lognormal distributions; individual lifetime fatal cancer risk per pCi/day).

\begin{tabular}{|l|c|c|}
\hline & ${ }^{226} \mathbf{R a}$ & ${ }^{228} \mathbf{R a}$ \\
\hline mean & & $1.0 \times 10^{-6}$ \\
\hline standard deviation & $1.5 \times 10^{-6}$ & $1.4 \times 10^{-6}$ \\
\hline lower $90 \%$ confidence limit & $9.0 \times 10^{-7}$ & $4.7 \times 10^{-7}$ \\
\hline upper $90 \%$ confidence limit & $9.4 \times 10^{-7}$ & $1.9 \times 10^{-6}$ \\
\hline
\end{tabular}

\subsubsection{Risk Characterization}

This section presents the risk characterization analysis for the ingestion of radium in fishes harvested near offshore produced water outfalls in the Gulf of Mexico. The risk characterization step includes the calculation of individual lifetime fatal cancer risk. The risk factor for the exposure period (5 - 65 years for recreational fishermen) was modified by adding 10 years to account for radium retention (see Appendix C):

$$
R F(E P)=\frac{(E P+10) \times U R F_{70}}{70 y}
$$

where:

$\mathrm{RF}(E P)=$ risk factor as a function of exposure period EP (lifetime risk per $\mathrm{pCi} /$ day)

$E P=$ exposure period (years)

$U \mathrm{UR}_{70}=$ USEPA unit risk factor for lifetime exposure (lifetime risk per pCi/day)

Individual lifetime fatal cancer risks were calculated as:

$$
I L R=I_{R a} \times R F(E P)
$$

where:

ILR = individual lifetime fatal cancer risk

$I_{R_{a}}=$ average daily radium intake during the exposure period (pCi/day)

Individual lifetime risks were calculated separately for ${ }^{226} \mathrm{Ra}$ and ${ }^{228} \mathrm{Ra}$ and then summed. 


\subsubsection{Results and Discussion}

Results of the probabilistic risk assessment for radium in fishes at Delacroix Island and Bay de Chene (pre-termination) are given in Table 6-6. Mean and median individual lifetime fatal cancer risks for both study sites were less than 1 $\times 10^{-5}$, and 95th percentile risks were less than $1 \times 10^{-4}$.

Results from the modeling analysis of continuing open bay discharges in Louisiana are also presented in Table 6-6. Median individual lifetime fatal cancer risks were $1.4 \times 10^{-6}$, and 95th percentile risks were $2.3 \times 10^{-5}$. Assumed background concentrations of radium in fish were associated with a median risk of $3.8 \times 10^{-7}$ and a 95 th percentile value of $1.3 \times 10^{-5}$.

These results suggest that ingestion of radium in fish caught near open bay produced water platforms does not present an important risk to human health.

There are a number of uncertainties associated with this analysis, including:

- uncertainty due to limited data describing radium concentrations in animals at USDOE study sites;

- uncertainty in modeling of radium dilution and bioaccumulation for continuing discharges;

- uncertainty in ingestion rate distribution; and

- uncertainty in radium dose-response function.

These uncertainties are considered in the probabilistic risk assessment by describing each of the relevant variables as a distribution in the Monte Carlo analysis. The results based on modeling continuing discharges overestimate risk from radium ingestion because of the conservatism of the CORMIX dilution model (see section 5.3), assumptions used in its application (e.g. all radium remains in solution), and the use of modeled plume concentrations at 200 feet to estimate exposure. 
Table 6-6. Probabilistic risk assessment for radium in fishes at Delacroix Island and Bay de Chene sampling sites: individual lifetime fatal cancer risk.

\begin{tabular}{|l|l|l|l|l|l|}
\hline \multirow{2}{*}{ SITE } & \multicolumn{5}{|c|}{ Individual Lifetime Fatal Cancer Risk } \\
\cline { 2 - 6 } & mean & median & $\begin{array}{l}\text { std. } \\
\text { deviation }\end{array}$ & $\begin{array}{l}5 \text { th } \\
\text { percentile }\end{array}$ & $\begin{array}{l}95 \text { th } \\
\text { percentile }\end{array}$ \\
\hline Delacroix Island & $6.2 \times 10^{-6}$ & $5.9 \times 10^{-6}$ & $2.4 \times 10^{-6}$ & $2.7 \times 10^{-6}$ & $1.1 \times 10^{-5}$ \\
\hline & & & & & \\
\hline Bay de Chene & $9.4 \times 10^{-1}$ & $7.9 \times 10^{-7}$ & $6.1 \times 10^{-1}$ & $2.6 \times 10^{-1}$ & $2.1 \times 10^{-6}$ \\
\hline $\begin{array}{l}\text { Continuing } \\
\text { Discharges }\end{array}$ & $5.3 \times 10^{-6}$ & $1.4 \times 10^{-6}$ & $1.6 \times 10^{-5}$ & $8.0 \times 10^{-8}$ & $2.3 \times 10^{-5}$ \\
\hline & & & & & \\
\hline Background & $5.0 \times 10^{-1}$ & $3.8 \times 10^{-1}$ & $4.4 \times 10^{-1}$ & $8.1 \times 10^{-8}$ & $1.3 \times 10^{-5}$ \\
\hline
\end{tabular}

${ }^{1}$ risk is for ingestion of fish, living in the plume 200 feet from the discharges. 


\section{ECOLOGICAL RISK ASSESSMENT FOR RADIONUCLIDES}

\subsection{Background and Approach}

An aquatic organism may be irradiated externally by radionuclides in water and sediment, and internally by radionuclides taken into the body by ingestion or direct absorption. Most incorporated radionuclides are differentially distributed among the organs and tissues of the organism. Radium, for example, tends to accumulate in bone, skin and exoskeleton.

Exposure to ionizing radiation can result in injury at the molecular, cellular and whole body levels. Most of the available studies of the effects of radiation on aquatic organisms are concerned with the induction of deterministic, somatic effects. These effects include increases in mortality and pathophysiological, developmental and reproductive effects. There is little information available concerning induction of cancer and genetic effects, although a few studies of stochastic genetic effects in organisms are available (Anderson and Harrison, 1986).

Appendix $\mathrm{C}$ reviews the terminology and units used in radiation protection, and summarizes the data available that describes the effects of radiation exposure on aquatic animals.

The National Council on Radiation Protection and Measurements recently reviewed the literature on the effects of ionizing radiation on aquatic organisms. NCRP (1991) suggested a reference dose rate to protect aquatic populations of $10 \mathrm{mGy} / \mathrm{d}$. NCRP also suggested a detailed assessment if an initial analysis results in an estimated dose rate above $2.4 \mathrm{mGy} / \mathrm{d}$.

IAEA (1988) suggested similar reference dose rates where effects on aquatic biota would be minimal. IAEA (1988) concluded that:

- increased mortality is expected above $10 \mathrm{mSv} / \mathrm{hr}(240 \mathrm{mSv} / \mathrm{d})$;

- reduced reproductive success may occur between 1 and $10 \mathrm{mSv} / \mathrm{hr}$ (24$240 \mathrm{mSv} / \mathrm{d}$ );

- some somatic effects which would be eliminated by natural selection could occur between 0.004 and $1 \mathrm{mSv} / \mathrm{hr}(0.1-24 \mathrm{mSv} / \mathrm{d})$; and

- no adverse effects are expected below background levels of $0.004 \mathrm{mSv} / \mathrm{hr}$ $(0.1 \mathrm{mSv} / \mathrm{d})$.

IAEA (1988) developed dose-rate factors that relate exposure to an organism to a unit concentration of a radionuclide in the water in which the organism lives (Table 7-1). These dose rate factors are based on models using assumptions concerning the bioaccumulation factor, $K_{d}$, and the sizes and shapes of the animals (IAEA, 1988). These factors are useful for screening purposes. 
Table 7-1. IAEA dose rate factors (mSv/hr per $\mathrm{Bq} / \mathrm{m}^{3}$ ).

\begin{tabular}{|c|c|c|c|c|c|}
\hline \multirow[t]{3}{*}{ ORGANISM } & \multicolumn{5}{|c|}{ RADIONUCLIDE } \\
\hline & ${ }^{226} \mathrm{Ra}$ & ${ }^{22} \mathrm{Ra}$ & ${ }^{210} \mathrm{~Pb}$ & ${ }^{210} \mathrm{Po}$ & ${ }^{220} \mathrm{Th}$ \\
\hline & & & & & \\
\hline bathypelagic & $1.38 \times 10^{-5}$ & $1.62 \times 10^{-1}$ & $4.96 \times 10^{-8}$ & $1.22 \times 10^{-4}$ & $2.21 \times 10^{-4}$ \\
\hline benthic & $1.45 \times 10^{-4}$ & $3.83 \times 10^{-6}$ & $8.00 \times 10^{-5}$ & $1.22 \times 10^{-4}$ & $1.26 \times 10^{-3}$ \\
\hline MOLLUSKS & $2.85 \times 10^{-4}$ & $4.41 \times 10^{-6}$ & $8.51 \times 10^{-5}$ & $6.10 \times 10^{-4}$ & $1.60 \times 10^{-3}$ \\
\hline CRUSTACEANS & & & & & \\
\hline large, bathypelagic & $2.77 \times 10^{-5}$ & $2.82 \times 10^{-8}$ & $2.46 \times 10^{-1}$ & $3.05 \times 10^{-4}$ & $3.68 \times 10^{-4}$ \\
\hline large, benthic & $3.54 \times 10^{-5}$ & $4.03 \times 10^{-6}$ & $1.82 \times 10^{-5}$ & $3.05 \times 10^{-4}$ & $1.52 \times 10^{-3}$ \\
\hline small, bathypelagic & $2.76 \times 10^{-5}$ & $1.86 \times 10^{-8}$ & $1.67 \times 10^{-1}$ & $1.83 \times 10^{-4}$ & $3.68 \times 10^{-3}$ \\
\hline small, benthic & $3.70 \times 10^{-5}$ & $4.76 \times 10^{-6}$ & $6.14 \times 10^{-4}$ & $1.83 \times 10^{-4}$ & $5.12 \times 10^{-3}$ \\
\hline
\end{tabular}

The IAEA screening dose-rate factors were used in a conservative screening analysis to identify the potential for ecological effects from radium and other radionuclides discharged in produced water to Louisiana open bays.

The data sets available for the analysis were:

- measured concentrations of ${ }^{226} \mathrm{Ra},{ }^{228} \mathrm{Ra}{ }^{210} \mathrm{~Pb},{ }^{210} \mathrm{Po}$ and ${ }^{228} \mathrm{Th}$ in the discharge at Delacroix Island and Bay de Chene Study Sites (section 4).

- measured concentrations of ${ }^{226} \mathrm{Ra}$ and ${ }^{228} \mathrm{Ra}$ in 47 continuing open bay discharges (section 5).

A dilution factor of 20 was applied to the concentrations of radionuclides measured in these effluents. A dilution factor of 20 was chosen to estimate worst-case concentrations because it yields more conservative concentrations than those predicted by the CORMIX model (section 5) at 50 and 200 feet from the discharge. The resulting water concentrations (in the plume at 200 feet from the discharge) were used to estimate the dose to aquatic animals using the IAEA dose conversion factors.

\subsection{USDOE Open Bay Sites}

Concentrations of radionuclides measured in the effluent at the Delacroix Island and Bay de Chene study sites are given in Table 7-2. A conservative dilution factor of 20 was applied to these concentrations to estimate worst-case radium concentrations 200 feet from open bay discharges (Table 7-2). The IAEA dose conversion factors were applied to these estimated water concentrations, and the total dose to aquatic organisms calculated (Table 7-3). No estimated doses 
exceeded the IAEA (1988) range of 0.1-24 mSv/d associated with the potential for only minor effects on individual animals.

Table 7-2. Screening-level concentrations of radionuclides predicted for 200 feet at the Delacroix Island and Bay de Chene study sites.

\begin{tabular}{|c|c|c|c|c|}
\hline \multirow{2}{*}{ Radionuclide } & \multicolumn{2}{|c|}{ Delacroix Island } & \multicolumn{2}{c|}{ Bay de Chene } \\
\cline { 2 - 5 } & $\begin{array}{c}\text { Discharge } \\
\text { (pCi//) }\end{array}$ & $\begin{array}{c}\text { Water Conc. } \\
\text { (pCi/l) }\end{array}$ & $\begin{array}{c}\text { Discharge } \\
\text { (pCi/l) }\end{array}$ & $\begin{array}{c}\text { Water Conc. } \\
\text { (pCi//) }\end{array}$ \\
\hline${ }^{210} \mathrm{~Pb}$ & 78.0 & 3.9 & 60.3 & 3.0 \\
\hline${ }^{210} \mathrm{Po}$ & $<1.1$ & $<0.06$ & $<2.0$ & $<0.1$ \\
\hline${ }^{226} \mathrm{Ra}$ & 218.5 & 10.9 & 162.5 & 8.1 \\
\hline${ }^{228} \mathrm{Ra}$ & 264.5 & 13.2 & 317.5 & 15.9 \\
\hline${ }^{228} \mathrm{Th}$ & 154.5 & 7.7 & 15.0 & 0.8 \\
\hline & & & & \\
\hline
\end{tabular}

Table 7-3. Screening level dose estimates for Delacroix Island and Bay de Chene study sites (mSv/d).

\begin{tabular}{|l|c|c|}
\hline ORGANISM & Delacroix Island & Bay de Chene \\
\hline FISH & & \\
\hline bathypelagic & 1.5 & 1.3 \\
\hline benthic & 2.5 & 2.0 \\
\hline MOLLUSKS & 4.3 & 3.5 \\
\hline CRUSTACEANS & 0.8 & \\
\hline large, bathypelagic & 1.8 & 0.8 \\
\hline large, benthic & 3.0 & 1.8 \\
\hline small, bathypelagic & 6.3 & 2.8 \\
\hline small, benthic & 6.3 & 5.5 \\
\hline
\end{tabular}

\subsection{Continuing Discharges}

Radium concentrations measured in 47 open bay discharges are given in Appendix B, and are summarized in Table 5-3. Mean and maximum concentrations are given in Table 7-4. A conservative dilution factor of 20 was applied to these concentrations to estimate worst-case radium concentrations 200 feet from open bay discharges (Table 7-4). A dilution factor of 20 was chosen to estimate worst-case concentrations because it yields more conservative concentrations than those predicted by the CORMIX model (section 5) at 200 feet from the discharge. 
Mean and maximum doses calculated using the IAEA dose rate conversion factors (Table 7-1) are given in Table 7-5. No estimated doses exceeded the IAEA (1988) range of $0.1-24 \mathrm{mSv} / \mathrm{d}$ associated with the potential for only minor effects on individual animals.

Table 7-4. Screening-level concentrations of radionuclides predicted for water 200 feet from open bay discharges.

\begin{tabular}{|c|c|c|c|c|}
\hline \multirow[t]{2}{*}{ Radionuclide } & \multicolumn{2}{|c|}{ Discharge } & \multicolumn{2}{|c|}{$\begin{array}{l}\text { Water Conc. } \\
\text { (pCi/l) }\end{array}$} \\
\hline & mean $(\mathrm{pC} \mathrm{i} / \mathrm{l})$ & $\operatorname{maximum}(\mathrm{pCi} / 1)$ & $\operatorname{mean}(\mathrm{pCi} / \mathrm{l})$ & maximum (pCi/l) \\
\hline${ }^{226} \mathrm{Ra}$ & 191.4 & 592.0 & 9.6 & 29.6 \\
\hline${ }^{228} \mathrm{Ra}$ & 250.0 & 560.0 & 12.5 & 28.0 \\
\hline
\end{tabular}

Table 7-5. Screening level dose estimates for radium in continuing open bay discharges (mSv/d).

\begin{tabular}{|l|c|c|}
\hline ORGANISM & \multicolumn{2}{|c|}{ Dose rate (mSv/d) } \\
\hline FISH & mean & maximum \\
\hline bathypelagic & 1.3 & 3.8 \\
\hline benthic & 1.3 & 4.0 \\
\hline & & 7.5 \\
\hline MOLLUSKS & 2.5 & \\
\hline & & 0.8 \\
\hline CRUSTACEANS & & 1.0 \\
\hline large, bathypelagic & 0.3 & 0.8 \\
\hline large, benthic & 0.3 & 1.0 \\
\hline small, bathypelagic & 0.3 & \\
\hline small, benthic & 0.3 & \\
\hline
\end{tabular}

\subsection{Discussion}

In this simple conservative screening analyses, doses to aquatic animals did not exceed the range associated with only minor effects of individual organisms (IAEA, 1988). No effects are expected to be found in aquatic animals in open bays in Louisiana, because of the conservative screening analysis yielded worst-case estimates of exposure. 


\section{HUMAN HEALTH RISK ASSESSMENT FOR METALS AND ORGANICS}

\subsection{Introduction and Approach}

A screening human health risk assessment was done (section 8.2 ) for metals and organic compounds measured in continuing open bay discharges (section 5). This analysis followed the USEPA approach to estimating risks from toxic materials and carcinogens by applying RfD (reference dose) and slope factor values to conservative estimates of chemical intake rates (USEPA, 1989a). Conservative predictions of water concentrations were also compared to USEPA and Louisiana human health surface water criteria.

A second level assessment (section 8.3) using a probabilistic approach was done for contaminants that the initial screening analysis suggested may be of potential concern. A separate probabilistic risk assessment was done for lead (section 8.4).

\subsection{Screening Assessment}

\subsubsection{Concentrations in Water and Fish}

Concentrations in the effluent for continuing open bay discharges were described by the data abstracted from LDEQ permit files (Table 5-2). These data overestimate average concentrations because only contaminants detected in the effluent above the reported detection limit are given.

A conservative dilution factor of 20 was chosen to estimate worst-case water contaminants concentrations in the plume 200 feet from the discharge. A dilution factor of 20 was chosen to estimate worst-case concentrations because it yields more conservative concentrations than those predicted by the CORMIX model (section 5) at 50 and 200 feet from the discharge. Most contaminants were assumed to remain in solution. Dissolved fractions of copper, lead and zinc were assumed to be $0.88,0.38$ and 0.59 , respectively (USEPA, 1995a).

In this assessment, contaminants were assessed only if they were reported above detection limits in more than two of the LDEQ permit files; and if toxicity data were available in IRIS or other USEPA literature. Worst-case mean and maximum chemical contaminant concentrations in effluents and in water at 200 feet are given in Table 8-1.

Conservative, generic bioaccumulation factors (Strenge and Peterson, 1989; were used to calculate concentrations of contaminants in edible fish (Table 8-1): 
$C F=(B A F \times C W) \times \frac{1 \mathrm{~kg}}{1,000 \mathrm{~g}}$

where:

CF = contaminant concentration in fish $(\mu \mathrm{g} / \mathrm{g})$

BAF = bioaccumulation factor $(\mathrm{l} / \mathrm{kg})$

$\mathrm{CW}=$ contaminant concentration in water $(\mu \mathrm{g} / \mathrm{l})$

Estimated concentrations in edible fish for worst-case mean and maximum contaminant discharge concentrations are given in Table 8-1.

Table 8-1. Estimated worst-case mean and maximum contaminant concentrations in the effluent, in the plume 200 feet from the discharge, and in edible fish.

\begin{tabular}{|c|c|c|c|c|c|c|c|c|}
\hline Contaminant & Effluen & t $(\mu g / l)$ & $\begin{array}{l}\text { Diss." } \\
\text { Fract. }\end{array}$ & $\begin{array}{r}\text { Concen } \\
\text { Water a } \\
\end{array}$ & $\begin{array}{l}\text { itration in } \\
\text { at } 200 \text { feet } \\
\mu \mathrm{g} / \mathrm{l})\end{array}$ & $\begin{array}{l}\text { BAF } \\
(1 / k g)\end{array}$ & $\begin{array}{l}\text { Concent } \\
\text { in Fish }\end{array}$ & $\begin{array}{l}\text { itration } \\
(\mu g / g)\end{array}$ \\
\hline & $\max$ & mean & & $\max$ & mean & & $\max$ & mean \\
\hline & & & & & & & & \\
\hline Antir & 0100 & 5595.9 & 1 & 1005 & 279.8 & 1 & 1.0 & 0.3 \\
\hline Arsenic & 498.5 & 74.8 & 1 & 24.925 & 3.7 & 1 & 0.02 & 0.004 \\
\hline Cadmium & 500 & 231.2 & 1 & 25 & 11.6 & 200 & 5 & 2.3 \\
\hline Chromium (VI) & 200 & 83.5 & 1 & 10 & 4.2 & 20 & 0.2 & 0.1 \\
\hline Copper & 710 & 288.4 & 0.88 & 31.2 & 12.7 & 50 & 1.6 & 0.6 \\
\hline Lead & 829000 & 104263 & 0.38 & 15751 & 1981 & 100 & 1575 & 198.1 \\
\hline Mercury & 27 & 7.1 & 1 & 1.35 & 0.4 & $2.0 \mathrm{E} 5$ & 270 & 70.8 \\
\hline Nickel & 2840 & 1013.9 & 1 & 142 & 50.7 & 100 & 14.2 & 5.1 \\
\hline Silver & 400 & 143.3 & 1 & 20 & 7.2 & 2.3 & 0.05 & 0.02 \\
\hline Zinc & 6375 & 1217.1 & 0.59 & 188.1 & 35.9 & $2.0 E 3$ & 376.1 & 71.8 \\
\hline & & & & & & & & \\
\hline$\overline{\mathrm{Be}}$ & & 3.2 & 1 & 77.5 & 90.7 & 24.1 & 11.5 & 2.2 \\
\hline Naphthalene & & .4 & 1 & 5.9 & 2.9 & 168 & 1.0 & 0.5 \\
\hline Phenol & 12000 & 1557.9 & 1 & 600 & 77.9 & 7.57 & 4.5 & 0.6 \\
\hline Toluene & 2800 & 831.6 & 1 & 140 & 41.6 & 69.9 & 9.8 & 2.9 \\
\hline Xylenes & 862 & 183.3 & 1 & 43.1 & 9.2 & 177 & 7.6 & 1. \\
\hline
\end{tabular}

* dissolved fraction (USEPA, 1995a)

*bioaccumulation factors (Strenge and Peterson, 1989)

\subsubsection{Risk Factors}

Risk factors (slope factors for carcinogens and reference doses (RfD) for toxicants) were obtained from the USEPA IRIS data base (April, 1995) and other sources. Table 8-2 summarizes these values. 


\section{Reference Dose}

The RfD (chronic reference dose) is "an active estimate (with uncertainty spanning perhaps an order of magnitude or greater) of a daily exposure level for the human population, including sensitive subpopulations, that is likely to be without an appreciable risk of deleterious effects during a lifetime. Chronic RfDs are specifically developed to be protective ..." (USEPA 1989a).

Each RfD includes uncertainty factors (UFs). Depending on the derivation of the RfD, uncertainty factors can inflate the RfD by up to 10,000 times. Therefore, an estimated exposure that exceeds an RfD for a particular contaminant may or may not exceed a threshold for toxicity. Toxicity values for many of the chemicals commonly found in produced water discharges are highly uncertain, as shown in Table 8-2.

RfDs undergoing review at USEPA are not available in IRIS. At the time of this analysis, current RfD's were not available for copper, mercury, lead and naphthalene, all contaminants with potential toxic effects. Estimates were available for mercury and naphthalene in HEAST (1991). These reference doses are interim values and have not been formally verified by USEPA.

No RfDs are available for lead or copper. Screening level estimates were derived for these contaminants as described below.

Copper:

- current maximum contaminant level goal for drinking water is $1.3 \mathrm{mg} / \mathrm{l}$

- assume based on 2 Vday water intake

- assume $70 \mathrm{~kg}$ adult

- $\operatorname{RfD}=0.04 \mathrm{mg} / \mathrm{kg}$-day

Lead:

- current data suggest effects at a blood level concentration of $10 \mu \mathrm{g} / \mathrm{dl}$ (Carlisle and Wade, 1992)

- slope of $0.04 \mu \mathrm{g} \mathrm{Pb} / \mathrm{dL}$ blood per $\mu \mathrm{g} /$ day in diet (Carlisle and Wade, 1992)

- assume $70 \mathrm{~kg}$ adult

- $\operatorname{RfD}=3.6 \times 10^{-3} \mathrm{mg} / \mathrm{kg}$-day 
Table 8-2. RfDs, uncertainty factors $(U)$, slope factors and human health water quality criteria.

\begin{tabular}{|c|c|c|c|c|c|c|c|}
\hline \multirow[t]{2}{*}{ Contaminant } & \multirow[t]{2}{*}{$\begin{array}{c}\text { RfD } \\
\text { (mg/kg-day) }\end{array}$} & \multirow[t]{2}{*}{ Confidence } & \multirow[t]{2}{*}{$\mathbf{U}$} & \multirow[t]{2}{*}{\begin{tabular}{|c|}
$\begin{array}{c}\text { Weight } \\
\text { of } \\
\text { Evidence }\end{array}$ \\
\end{tabular}} & \multirow[t]{2}{*}{$\begin{array}{c}\text { Slope Factor } \\
\text { risk per } \\
\text { mg/kg-day }\end{array}$} & \multicolumn{2}{|c|}{$\begin{array}{l}\text { Human Health } \\
\text { Criteria For Fish } \\
\text { Ingestion( } \mu \text { g/l) }\end{array}$} \\
\hline & & & & & & USEPA & LDEQ \\
\hline Antimony & $4.00 \times 10^{-4}$ & Low & 1000 & - & - & $4.50 \times 10^{4}$ & - \\
\hline Arsenic. & $3.00 \times 10^{-4}$ & Medium & 3 & $\bar{A}$ & $5.00 \times 10^{-5}$ & $1.75 \times 10^{-2}$ & - \\
\hline Cadmium & $1.00 \times 10^{-3}$ & High & 10 & $B 1$ & - & - & -- \\
\hline Chromium (VI) & $5.00 \times 10^{-3}$ & Low & 500 & $A^{* * *}$ & - & - & - \\
\hline Copper & $4.00 \times 10^{-2}$ & 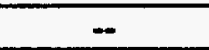 & - & $\mathrm{D}$ & -- & - & -- \\
\hline Lead* & $3.60 \times 10^{-3}$ & -- & - & $\mathrm{B2}$ & - & - & - \\
\hline Mercury & $3.00 \times 10^{-1}$ & $-\infty$ & - & D & - & $1.46 \times 10^{-1}$ & - \\
\hline Nickel & $2.00 \times 10^{-2}$ & Medium & 300 & - & -- & $1.00 \times 10^{2}$ & - \\
\hline Silver & $5.00 \times 10^{-3}$ & Low & 3 & D & $\because$ & - & -- \\
\hline Zinc & $3.00 \times 10^{-1}$ & Medium & 3 & $D$ & -- & - & - \\
\hline & & & & & - & -- & - \\
\hline Benzene & - & - & - & $\bar{A}$ & $2.90 \times 10^{-2}$ & $4.00 \times 10^{1}$ & 12.5 \\
\hline Naphthalene & $4.00 \times 10^{-3}$ & - & - & D & -- & $\overline{--}$ & $\overline{--}$ \\
\hline Phenol & $6.00 \times 10^{-1}$ & Low & 100 & $\bar{D}$ & -- & -- & 50 \\
\hline Toluene & $2.00 \times 10^{-1}$ & Medium & 1000 & $\bar{D}$ & - & $4.24 \times 10^{5}$ & $6.93 \times 10^{4}$ \\
\hline Xylenes & 2.00 & Medium & 100 & D & -- & - & - \\
\hline
\end{tabular}

* no RfD available in IRIS, screening values derived in text

*t no RfD available in IRIS, screening values from HEAST (1991)

* evidence is for inhalation carcinogenesis only

\section{Hazard Quotients}

For noncarcinogenic toxicity risk characterization of individual contaminants, USEPA (1989a) uses a hazard quotient (HQ), "the ratio of a single substance exposure level over predicted a specified time period (e.g. subchronic) to a reference dose for that substance derived from a similar exposure period". In this report the $H Q$ concept is extended to utilize any comparable reference standard for human health or ecological risks. Such standards include RfDs and human health water quality criteria. The term $H Q$ is reserved for the ratio derived using the RfD; WHQ (water quality criteria hazard quotient) is the ratio of the predicted water concentration to the USEPA human health water quality criteria for the contaminant.

\section{Slope Factor}

A slope factor is "a plausible upper-bound estimate of the probability of a response per unit intake of a chemical over a lifetime. The slope factor is used in risk assessments to estimate an upper-bound (italics added) lifetime probability of an individual developing cancer as a result of a lifetime exposure to a level of a particular carcinogen" (USEPA, 1989a) The upper bound is 
usually the upper 95th percent limit of the slope of a calculated dose-response curve. "In some cases slope factors based on human dose-response data are based on the "best" estimate instead of the upper 95 percent confidence limits" (USEPA, 1989a) Each USEPA slope factor is accompanied by a weight-of evidence classification, a "...system for characterizing the extent to which the available data indicate that an agent is a human carcinogen" (USEPA, 1989a). The weight of evidence classification used by USEPA is as follows:
A Human carcinogen
B1 Probable human carcinogen based on limited human data
B2 Probable human carcinogen based on sufficient evidence in animals only
C Possible human carcinogen
D Not classifiable as to human carcinogenicity
E Evidence of noncarcinogenicity in human beings

\subsubsection{Exposure Assumptions}

The screening analyses used a conservative value of 70 years as the duration of exposure, to reflect an assumption of a lifetime exposure. A conservative ingestion rate of $132 \mathrm{~g} / \mathrm{d}$ was used (USEPA 1989a; 95th percentile value), along with an exposure frequency of $365 \mathrm{~d} / \mathrm{year}$. An assumed body weight of $70 \mathrm{~kg}$ for adults was used in the analysis (USEPA, 1990). Intakes were averaged over a 70 year lifetime.

\subsubsection{Exposure Assessment and Risk Characterization}

Intake rates for contaminants in finfish caught near coastal open bay platforms were calculated following USEPA methods developed for the assessment of Superfund sites (USEPA, 1989a).

$$
I=\frac{\left(C F \times I_{f s h} \times F \times E F \times E D\right)}{(B W \times A T)}
$$


where:

$I=$ intake rate $(\mathrm{mg} / \mathrm{kg}-\mathrm{d})$

$\mathrm{CF}=$ concentration in finfish $(\mathrm{mg} / \mathrm{kg})$

$l_{\text {fish }}=$ ingestion rate $(0.132 \mathrm{~kg} / \mathrm{d}$; USEPA, 1989a)

$F=$ fraction of fish from contaminated source (1.0)

$E F=$ exposure frequency ( $365 \mathrm{~d} /$ year; USEPA, 1989a)

$E D=$ exposure duration (70 years; USEPA, 1989a)

$A T=$ averaging time (70 years $\times 365 \mathrm{~d} /$ year; USEPA, 1989a)

BW = body weight $(70 \mathrm{~kg}$; USEPA, 1989a)

The risks associated with the ingestion of contaminants in finfish caught near coastal open bay platforms were calculated following EPA methods developed for assessments at Superfund sites (USEPA, 1989a):

Toxicity

$H Q=\frac{I}{R f D}$

where:

$H Q=$ hazard quotient

I = intake rate $(\mathrm{mg} / \mathrm{kg}-\mathrm{d})$

$\mathrm{RfD}=$ reference dose $(\mathrm{mg} / \mathrm{kg}-\mathrm{d})$

Hazard quotients greater than one suggest a potential for chronic toxic effects.

Carcinogenicity

$I R=I \times S F$

where:

IR = individual incremental lifetime fatal cancer risk

I = intake rate $(\mathrm{mg} / \mathrm{kg}-\mathrm{d})$

$\mathrm{SF}=$ slope factor (risk per $\mathrm{mg} / \mathrm{kg}-\mathrm{d}, 70$ year exposure period)

\subsubsection{Water Quality Criteria}

Worst-case mean and maximum predicted water concentrations at 200 feet from the discharge were compared to USEPA and LDEQ water quality criteria for human health (for fish ingestion; Table 8-2). A WHQ [predicted water concentration/water quality criteria] was calculated for each contaminant. Where WHQs are greater than one, this conservative screening analysis predicts that the human health water quality will be exceeded. 


\subsubsection{Screening Analysis Results}

Results of the screening risk assessment for the continuing open bay discharges in Louisiana are given in Tables 8-3 and 8-4.

Arsenic, chromium, copper, silver, naphthalene, toluene and xylenes were eliminated from further consideration. Contaminants with screening hazard quotients greater than one were antimony, cadmium, lead, mercury nickel, and zinc. Screening cancer risk estimates for benzene exceed $1 \times 10^{-1}$. Benzene is the only carcinogen of potential concern. Contaminants that exceeded human health water quality criteria in the screening analysis were: mercury, nickel, benzene and phenol.

Major uncertainties and conservative assumptions in this screening assessment included:

- use of worst-case water concentrations;

- use of average chemical concentrations that excluded zero values;

- use of conservative ingestion rates and exposure periods;

- use of generic bioaccumulation factors; and

- use of uncertain reference doses that either include large safety factors or are not verified by USEPA (lead, mercury, antimony, nickel).

A more realistic and quantitative assessment was performed for contaminants identified in this screening analysis (section 8.3). Because of the concern for lead exposure to children, and the current belief that the dose-response function for lead exposure does not have a threshold, lead was analyzed in a separate probabilistic risk assessment (section 8.4).

\subsection{Quantitative Analysis for Antimony, Cadmium, Mercury, Nickel, Zinc, Benzene and Phenol}

For chemicals not eliminated by the screening assessments, distributions of concentrations in produced water discharges were developed from permit data (Table 8-5). Values for chemicals that were not detected were assigned one-half the reported detection limit value. Each chemical, except cadmium and copper, was assigned a lognormal distribution, after a log probability plot of the frequency of measured values yielded a linear fit (Layton et al., 1987). Cadmium was assigned a custom distribution that matched the relative frequencies of the values in the available data set. 
Table 8-3. Hazard quotients $\left(H Q^{1}\right)$ and cancer risk estimates (shaded values exceed a HQ of 1.0 or an individual lifetime fatal cancer risk of $1 \times 10^{-4}$ ).

\begin{tabular}{|c|c|c|c|c|}
\hline \multirow[t]{2}{*}{ Contaminant } & \multicolumn{2}{|c|}{$H Q^{\top}$} & \multicolumn{2}{|c|}{$\begin{array}{l}\text { Individual Lifetime } \\
\text { Fatal Cancer Risk }\end{array}$} \\
\hline & maximum & mean & maximum & mean \\
\hline & & & & \\
\hline Antimony & \% & S & - & -- \\
\hline Arsenic & 0.2 & 0.02 & $2.4 \times 10^{-9}$ & $3.5 \times 10^{-1}$ \\
\hline Cadmium & \% & $4 \%$ & - & - \\
\hline Chromium (VI) & 0.07 & 0.03 & - & - \\
\hline Copper & 0.07 & 0.03 & - & $-\infty$ \\
\hline Lead & 625 & $10 \%$ & - & - \\
\hline Mercury & 1697.6 & \% 1551 & - & -- \\
\hline Nickel & 18 & 0.5 & -- & - \\
\hline Silver & 0.02 & 0.006 & $\overline{-}$ & - \\
\hline \multirow[t]{2}{*}{ Zinc } & 24 & 0.5 & - & -- \\
\hline & & & - & - \\
\hline Benzene & - & - & $1653 \times 10 \%$ & 62610 \\
\hline Naphthalene & 0.5 & 0.2 & - & -- \\
\hline Phenol & 0.01 & 0.002 & - & - \\
\hline Toluene & 0.1 & 0.03 & - & -- \\
\hline Xylenes & 0.01 & 0.002 & - & -- \\
\hline
\end{tabular}

${ }^{\top} \mathrm{HQ}=$ Intake Rate/RfD

Table 8-4. Water Quality Criteria Hazard Quotients (WHQ ${ }^{1}$ ) at 200 feet (shaded values exceed a ratio of 1.0 ).

\begin{tabular}{|c|c|c|c|c|}
\hline \multirow[t]{2}{*}{ Contaminant } & \multicolumn{2}{|c|}{ Louisiana Criteria } & \multicolumn{2}{|c|}{ USEPA Criteria } \\
\hline & maximum & mean & maximum & mean \\
\hline Antimony & - & -- & 0.02 & 0.006 \\
\hline Arsenic & - & - & - & - \\
\hline Cadmium & - & 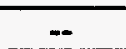 & - & - \\
\hline Chromium (VI) & - & - & - & - \\
\hline Copper & -- & -- & - & - \\
\hline Lead & - & -- & - & - \\
\hline Mercury & - & - & OS & $\%$ \\
\hline Nickel & - & -- & $1 \%$ & 0.5 \\
\hline Silver & -- & -- & - & - \\
\hline Zinc & - & -- & - & - \\
\hline & $=$ & $\overline{-}$ & - & - \\
\hline Benzene & $18 \%$ & 3 & 12 & 23 \\
\hline Naphthalene & - & - & - & - \\
\hline Phenol & 82 & 16 & - & -- \\
\hline Toluene & 0.002 & 0.0006 & $3.3 \times 10^{-4}$ & $9.1 \times 10^{-5}$ \\
\hline Xylenes & - & -- & - & - \\
\hline
\end{tabular}

WHQ = predicted concentration at 200 feet $/$ water quality criteria for human health 
Table 8-5. Distributions of concentrations of contaminant $(\mu \mathrm{g} / \mathrm{l})$ found in discharges from open bay platforms.

\begin{tabular}{|l|l|c|c|c|c|}
\hline Chemical & Distribution & Mean & SD & Minimum & Maximum \\
\hline & & & & & \\
\hline Antimony & Lognormal & 3192.6 & 6268.3 & 11.8 & 20,100 \\
\hline Cadmium & Custom & 217.9 & 235.6 & 0.0015 & 540 \\
\hline Mercury & Lognormal & 4.3 & 11.1 & 0.0005 & 41 \\
\hline Nickel & Lognormal & 569.1 & 947.9 & 20 & 2,480 \\
\hline Zinc & Lognormal & 1465.3 & 2768.3 & 2.5 & 10,800 \\
\hline Benzene & Lognormal & 1315.5 & 1909.6 & 2.5 & 6,420 \\
\hline Phenol & Lognormal & 1257.3 & 2743.4 & 5 & 12,000 \\
\hline & & & & & \\
\hline
\end{tabular}

These distributions were used with the relationships derived from results of CORMIX modeling to obtain distributions of the concentrations of each contaminant at 200 feet in the plume (Table 8-6; see section 5-3). Each chemical was assumed to be totally soluble in water except for zinc which was assumed to have a fractional solubility of 0.59 .

Table 8-6. Predicted concentrations of contaminants $(\mu \mathrm{g} / \mathrm{l})$ in plumes, at 200 feet from discharges of produced waters.

\begin{tabular}{|l|c|c|c|c|}
\hline Chemical & Mean & SD & Minimum & Maximum \\
\hline & & & & \\
\hline Antimony & 1.8 & 2.2 & 0.02 & 13.4 \\
\hline Cadmium & 0.5 & 1.3 & $9.2 \times 10^{-5}$ & 13.2 \\
\hline Mercury & 0.01 & 0.03 & $3.6 \times 10^{-5}$ & 0.6 \\
\hline Nickel & 1.4 & 3.3 & $3.9 \times 10^{-3}$ & 52.2 \\
\hline Zinc & 0.5 & 0.4 & 0.007 & 4.2 \\
\hline Benzene & 3.2 & 7.6 & 0.01 & 117.7 \\
\hline Phenol & 3.3 & 9.7 & 0.01 & 170.0 \\
\hline & & & & \\
\hline
\end{tabular}

These concentrations were used in a probabilistic analyses of potential human health effects. Exposure of humans was assumed to be from eating $100 \%$ of their recreationally caught seafood intake as fish caught in a plume, within 200 feet of a discharge.

The distribution of concentrations of a contaminant in fish (CF, Table 8-7) was calculated by applying the distribution for contaminant concentrations in water, and the bioaccumulation factors given in Table 8-1 to equation (8.1).

The distribution of exposure ( $\mathrm{mg} / \mathrm{kg}-\mathrm{d}$ ) to humans by ingestion of fish caught in the plume was calculated using the parameter distributions and values from Table 8-8 in Equation (8.2). 
Table 8-7 Predicted concentrations of chemicals $(\mathrm{mg} / \mathrm{kg})$ in finfishes, assumed to live in plumes, within $\mathbf{2 0 0}$ feet from discharges of produced waters.

\begin{tabular}{|l|c|c|c|c|}
\hline Chemical & Mean & SD & Minimum & Maximum \\
\hline & & & & \\
\hline Antimony & $1.8 \times 10^{-3}$ & $2.2 \times 10^{-3}$ & $2.4 \times 10^{-5}$ & $1.3 \times 10^{-2}$ \\
\hline Cadmium & 0.11 & 0.3 & $1.8 \times 10^{-6}$ & 2.6 \\
\hline Mercury & $2.0 \times 10^{-10}$ & $6.5 \times 10^{-10}$ & $7.2 \times 10^{-14}$ & $1.2 \times 10^{-8}$ \\
\hline Nickel & 0.14 & 0.05 & $3.9 \times 10^{-4}$ & 5.2. \\
\hline Zinc & $1.5 \times 10^{-4}$ & $1.9 \times 10^{-4}$ & $2.1 \times 10^{-6}$ & $1.3 \times 10^{-3}$ \\
\hline Benzene & 0.08 & 0.18 & $1.2 \times 10^{-4}$ & 2.8 \\
\hline Phenol & $2.5 \times 10^{-2}$ & $7.3 \times 10^{-2}$ & $9.4 \times 10^{-5}$ & 1.3 \\
\hline & & & & \\
\hline
\end{tabular}

Table 8-8. Parameters used in the exposure calculations.

\begin{tabular}{|c|c|}
\hline Parameter & Value or Distribution \\
\hline CF concentration in fish $(\mathrm{mg} / \mathrm{kg})$ & $\begin{array}{l}\text { calculated from equation } 8.1 \text { and Table } 8 \text { - } \\
7 \text {. }\end{array}$ \\
\hline$I_{\text {fish }}$ fish ingestion rate $(\mathrm{kg} / \mathrm{d})$ & $\begin{array}{l}\text { lognormal, mean: } 38.4 \text {; sd: } 26.4 \text {; range: } \\
3.3-228.6 \text { (section } 5 \text { ) }\end{array}$ \\
\hline F fraction of fish from contaminated source & 1.0 \\
\hline ED exposure duration (y) & $\begin{array}{l}\text { Triangular: most frequent 20; range } 5 \text { to } \\
65\end{array}$ \\
\hline EF exposure frequency $(d / y)$ & $365 \mathrm{~d} / \mathrm{y}$ (USEPA, 1989a) \\
\hline BW body weight $(\mathrm{kg})$ & $\begin{array}{l}\text { Age-weighted lognormal: mean 58; SD } 14 \\
\text { (McKone and Daniels, 1991). }\end{array}$ \\
\hline AT . averaging time (d) & $E D(y) \times 365(d / y)$ \\
\hline
\end{tabular}


The HQ (ratio of the predicted range of exposures to the RfD (Table 8-9) was calculated for each contaminant (with the exception of benzene) and the percent probability of exceeding the RfD was determined for each contaminant.

Table 8-9. Probability that the HQ (from ingestion of fish caught within $200 \mathrm{ft}$ of a produced water discharge) equals or exceeds 1.0.

\begin{tabular}{|c|c|c|c|c|}
\hline Contaminant & $\begin{array}{c}R f D \\
(\mathrm{mg} / \mathrm{kg}-\mathrm{d})\end{array}$ & $\begin{array}{c}\text { Mean } \\
\text { HQ }\end{array}$ & $\begin{array}{c}\text { Maximum } \\
\mathrm{HQ}\end{array}$ & $\% p(H Q) \geq 1$ \\
\hline Antimony & $4 \times 10^{-4}$ & $3 \times 10^{-3}$ & $5 \times 10^{-2}$ & 0 \\
\hline Cadmium & $1 \times 10^{-3}$ & 0.08 & 3.0 & 1.4 \\
\hline Mercury & $3 \times 10^{-4}$ & $7 \times 10^{-9}$ & $4 \times 10^{-1}$ & 0 \\
\hline Nickel & $2 \times 10^{-2}$ & $5 \times 10^{-3}$ & 0.16 & 0 \\
\hline Zinc & $2 \times 10^{-3}$ & $3 \times 10^{-4}$ & $4 \times 10^{-3}$ & 0 \\
\hline Phenol & $6 \times 10^{-1}$ & $3 \times 10^{-5}$ & $1 \times 10^{-3}$ & 0 \\
\hline
\end{tabular}

The results show that intakes of chemical contaminants, by eating fish, pose a negligible toxic hazard to human health, when the contaminants are considered individually. The only chemical that marginally exceeded its oral RfD value was cadmium (Figure 8-1).

For benzene, the slope factor $\left(2.9 \times 10^{-2}\right)$ from USEPA'S IRIS was multiplied by the predicted range of exposures to yield a distribution of yalues for incremental individual lifetime rissk of cancer mortality: mean, $1.6 \times 10^{-6} ; \mathrm{SD}, 3.9 \times 10^{-6} ; 95$ th percentile, $7.4 \times 10^{-6}$ (Figure 8-2). This is within the range considered acceptable by USEPA ( $1 \times 10^{-6}$ to $1 \times 10^{-4}$; Federal Register, 1991).

These analyses used several conservative assumptions. The first assumption was that all the fish spend all of their time living and feeding within the plume, although they probably spend only a fraction of time within a plume. The predicted concentrations represent values at the midline of the plume 200 feet from the discharge. These values were generated by a model that conservatively underestimates dilution (Smith et al., 1993). It was also assumed that all the fish eaten by a person were captured at the midline of a plume, while people may eat fish from several sources. Although contaminant concentrations in water should increase with decreasing distances from a discharge, bioaccumulation in fish would be offset by expected reduced residence of fish within the smaller plume volumes. 
Figure 8-1. Hazard quotient (HQ) for chronic oral exposure to cadmium.

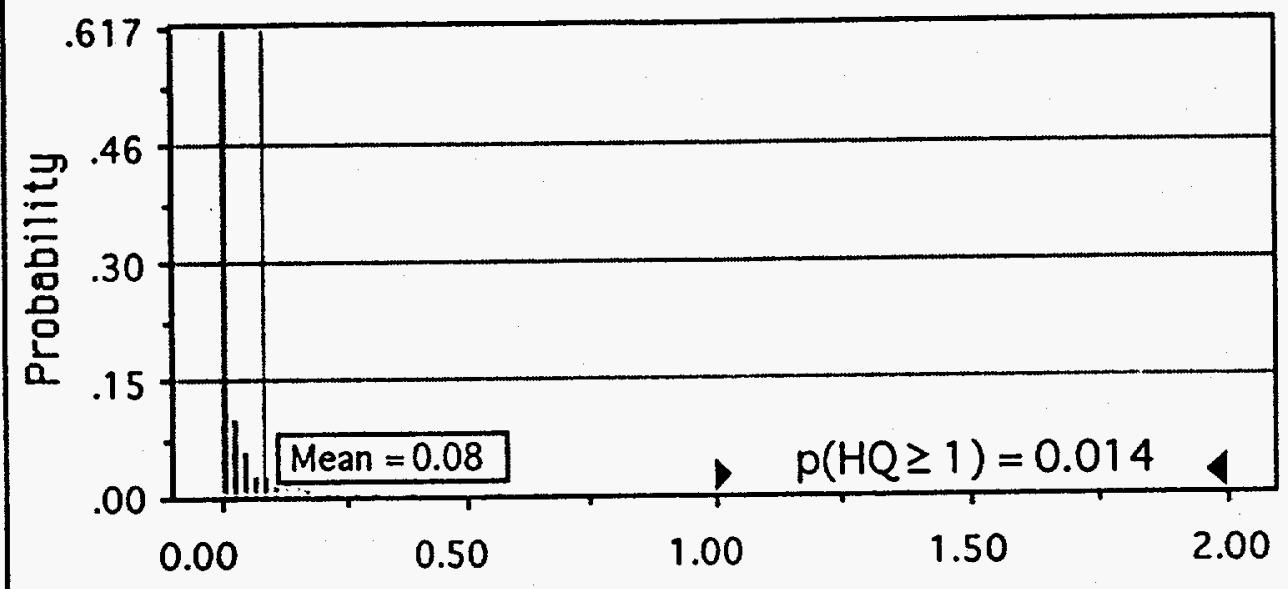

Figure 8-2. Incremental individual lifetime risk of cancer from benzene intake by ingesting fish (right marker on $x$ axis is at the 95th percentile).

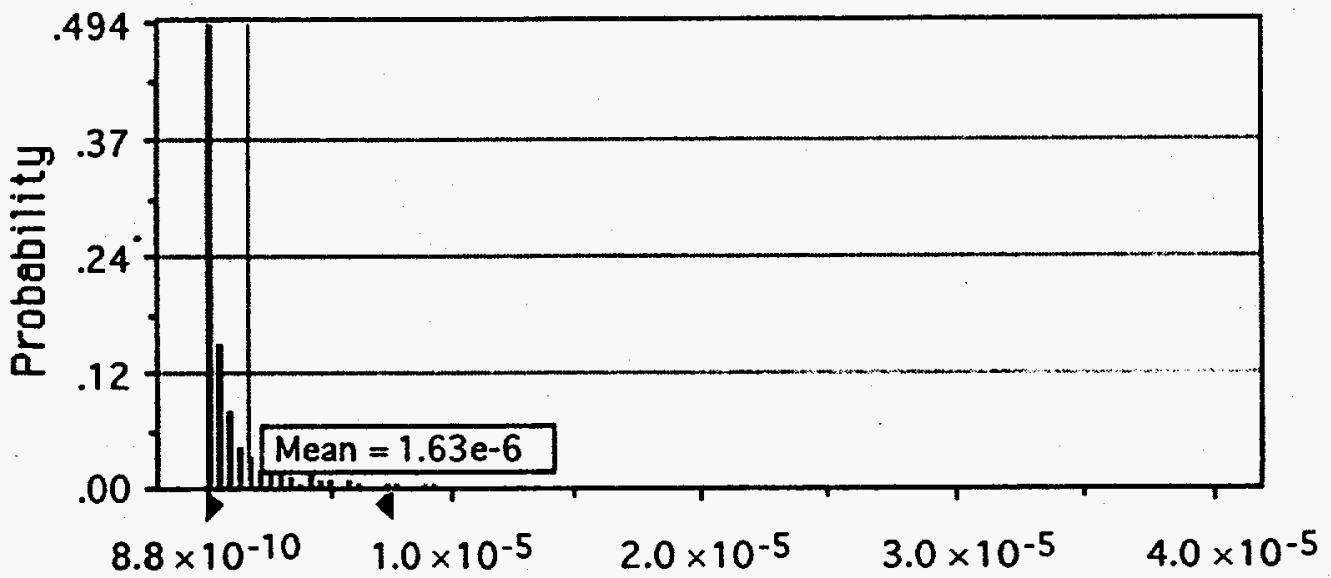




\subsection{Probabilistic Risk Assessment for Lead}

\subsubsection{Concentrations in Water}

Measured concentrations of lead in open bay produced water discharges, reported in LDEQ permit files, are summarized in Table 8-10. The largest lead concentration reported in permit files $(800,000 \mu \mathrm{g} / \mathrm{l})$ was several orders of magnitude larger than maximum values reported in other studies (Stephenson, 1992; Middleditch, 1984) and was not included in the data set for the risk assessment. Many of the lead concentrations in produced water were reported as "less than $(<)^{n}$ the detection limit. The detection limit for lead ranged from 50 to $125 \mu \mathrm{g} / \mathrm{l}$. These values were replaced by one-half the value of the reported detection limit.

To estimate ambient water concentrations, the distribution of lead concentrations reported for open bay discharges was modified by the distribution of dilution factors (DFs). Thirty-eight percent of lead was assumed to remain in solution based on calculations performed by LDEQ (USEPA, 1995a). Table 8-10 gives estimated lead concentrations in the water column at 200 feet.

\subsubsection{Concentrations in Fish}

\subsubsection{Fish Near Platforms}

A distribution for a lead BAF was developed from published estimates. In a report prepared for USEPA, Avanti Corporation (1993) cited a range of 10 to 100 for bioaccumulation of lead. IAEA (1982) presented a default BAF of 300 for lead in seawater. A triangular distribution for BAF of lead ranging from 10 to 300 , with a most likely value of 100 was used in this analysis.

Lead concentrations in fish near produced water discharges (Table 8-10) were estimated using the bioaccumulation factor (BAF) method in equation (8.1).

Table 8-10. Lead concentrations in open bay produced water discharges, and estimated concentrations in water and fish in the plume at 200 feet.

\begin{tabular}{|l|c|c|c|}
\hline & Effluent & Ambient Water $^{{ }^{2}}$ & Fish $^{3}$ \\
\hline & & & \\
\hline mean & 546.8 & 0.53 & 0.07 \\
\hline sd deviation & 934.5 & 1.14 & 0.17 \\
\hline minimum & 25.0 & 0.0 & 0.0 \\
\hline maximum & 2,600 & 12.9 & 1.95 \\
\hline
\end{tabular}

Measured in effluent: $\mu g / 1$.

${ }^{2}$ Modeled concentrations in water: $\mu g / l$.

${ }^{3}$ Modeled concentrations in fish: $\mu g / g$ 


\subsubsection{Fish Away From Platforms}

For comparison, concentrations of lead in fish caught in the Gulf of Mexico away from platforms (and associated health risks) were estimated. Distributions of lead in fish not associated with platforms were derived from measured concentrations of lead in whole fishes at two Environmental Monitoring and Assessment Program (EMAP) sites on the coast of Louisiana (USEPA, 1995b). These measurements may under- or overestimate background concentrations because the samples were of whole fish rather than edible fillets. Concentrations in fish caught away from platforms were assumed to be lognormally distributed with an arithmetic mean value of $0.05 \mu \mathrm{g} / \mathrm{g}$ (standard deviation: 0.06 ; range: $0.01-0.28$ ). Although the data used in deriving this distribution have been funded wholly or in part by the USEPA through its EMAPEstuaries Program, it has not been subjected to Agency review, and therefore does not necessarily reflect the views of the Agency and no official endorsement should be inferred.

\subsubsection{Intake}

\subsubsection{Background Intake}

Lead is ubiquitous in the environment, and children, in particular, are exposed to lead through a number of pathways. Sources of lead exposure to children include food, drinking water, air, soil and dust. Exposures from specific sources are added to background exposures experienced by children and increase the probability of exceeding blood lead levels of concern identified by USEPA. This analysis assumed age-specific background intakes for children ages one-half to 7 years, as described in USEPA (1994).

\subsubsection{Recreational Fishing}

Lead intake was estimated for children eating fish caught either near platforms, or away from platforms. Distributions of lead intake in recreationally caught fish were calculated as:

$$
I_{P b}=I_{\text {fish }} \times[P b]_{f i s h e s}
$$

where:

$I_{P b}=$ lead intake $(\mu \mathrm{g} /$ day $)$

$I_{\text {fiah }}=$ intake of fish ( $\left.g / d a y\right)$ for children of recreational fishermen (section 5 )

$[\mathrm{Pb}]_{\text {fretes }}=$ concentration of lead in fish $(\mu \mathrm{g} / \mathrm{g})$ 
Intake estimates were divided into groups (15 groups for fish caught near platforms, 13 groups for fish caught away from platforms) and the midpoint of the intake range for each group was used to represent the intake of lead ingested in recreationally caught fish. Daily lead ingestion rates in food were calculated for each year of life to age 7 by adding the background intake for that age (USEPA, 1994) to the estimated intake from recreationally caught fish. This approach slightly overestimates lead intake in food because recreationally caught fish would actually replace a small amount of lead in fish and meat obtained from other sources.

\subsubsection{Dose-response Assessment}

Lead exposure can affect a number of systems, including the brain, hematopoietic system, cardiovascular system and the developing fetus (Derosa et al., 1991). Extensive data are available to link low-level lead exposure of young children to deficits in neurobehavioral-cognitive performance (Rosen, 1995). Federal agencies and advisory groups including USEPA (USEPA, 1986), have defined a level of concern for children as a blood lead level $\geq 10 \mu \mathrm{g} / \mathrm{dl}$ (Rosen, 1995; USEPA, 1994). USEPA has developed a biokinetic/uptake model for lead (UBK Model; USEPA, 1994) that relates intake in food, air, water and soil to the probability of exceeding a blood lead level of $10 \mu \mathrm{g} / \mathrm{dl}(B L>10)$. This analysis used this probability as the metric for risk from ingestion of lead in fish.

\subsubsection{Risk Characterization}

The UBK model (USEPA, 1994) was used to estimate the blood lead concentration and the probability of $B L>10$ for each level of intake of recreationally caught fish. All other UBK model parameters reflected USEPA (1994) estimates of average background intakes.

Blood lead levels were estimated for two age groups: age 1-2 years when they are at their maximum level for a given intake; and averaged over age 0 to 7 years. Figure 8-3 shows the relationship between the intake of lead in recreationally caught fish and the probability of $B L>10$. For comparison, background intakes of lead are associated with a probability of $B L>10$ of $1.56 \%$ for age $0-7$ years and of $4.42 \%$ for age $1-2$ years.

The total risk (that is, the probability that $B L>10$ across all predicted intake rates) was calculated as:

$$
T P=\sum P\left(I_{P b}\right) \times P\left(B L>10 \mid I_{P b}\right)
$$


where:

TP $=$ total probability $(\%)$ of exceeding a blood lead level of $10 \mu \mathrm{g} / \mathrm{dl}$

$P\left(I_{p b}\right)=$ probability $(\%)$ of a given lead intake in recreationally caught fish

$P\left(B L>10 \mid I_{P b}\right)=$ probability $(\%)$ of exceeding a blood lead level of $10 \mu \mathrm{g} / \mathrm{dl}$ for a given intake of lead in fish

\subsubsection{Results}

Table 8-11 shows the total probability of $B L>10$ for fish caught near platforms, fish caught away from platforms and background intakes. Risk from ingestion of fish caught away from platforms only slightly exceeded risks from background intake of lead and was similar to those associated with ingestion of fish caught away from platforms in the Gulf of Mexico. Because of the conservatisms embedded in the analysis (assumptions concerning "less than" effluent concentrations, underestimate of dilution at low discharges rates) the risk from ingestion of lead discharged from open bay discharges in Louisiana appears to be small.

Table 8-11. Total probability (\%) of exceeding a blood lead level of $10 \mu \mathrm{g} / \mathrm{dl}$.

\begin{tabular}{|l|c|c|}
\hline & $0-7$ years & $1-2$ years \\
\hline Fish Near Platforms & 2.3 & 4.8 \\
Fish Away From Platforms & 2.0 & 4.8 \\
Background & 1.6 & 4.4 \\
\hline
\end{tabular}


Figure 8-3. Relationship between intake of lead in recreationally caught fish and probability of exceeding $10 \mu \mathrm{g} / \mathrm{dl}$ blood lead for two age groups.

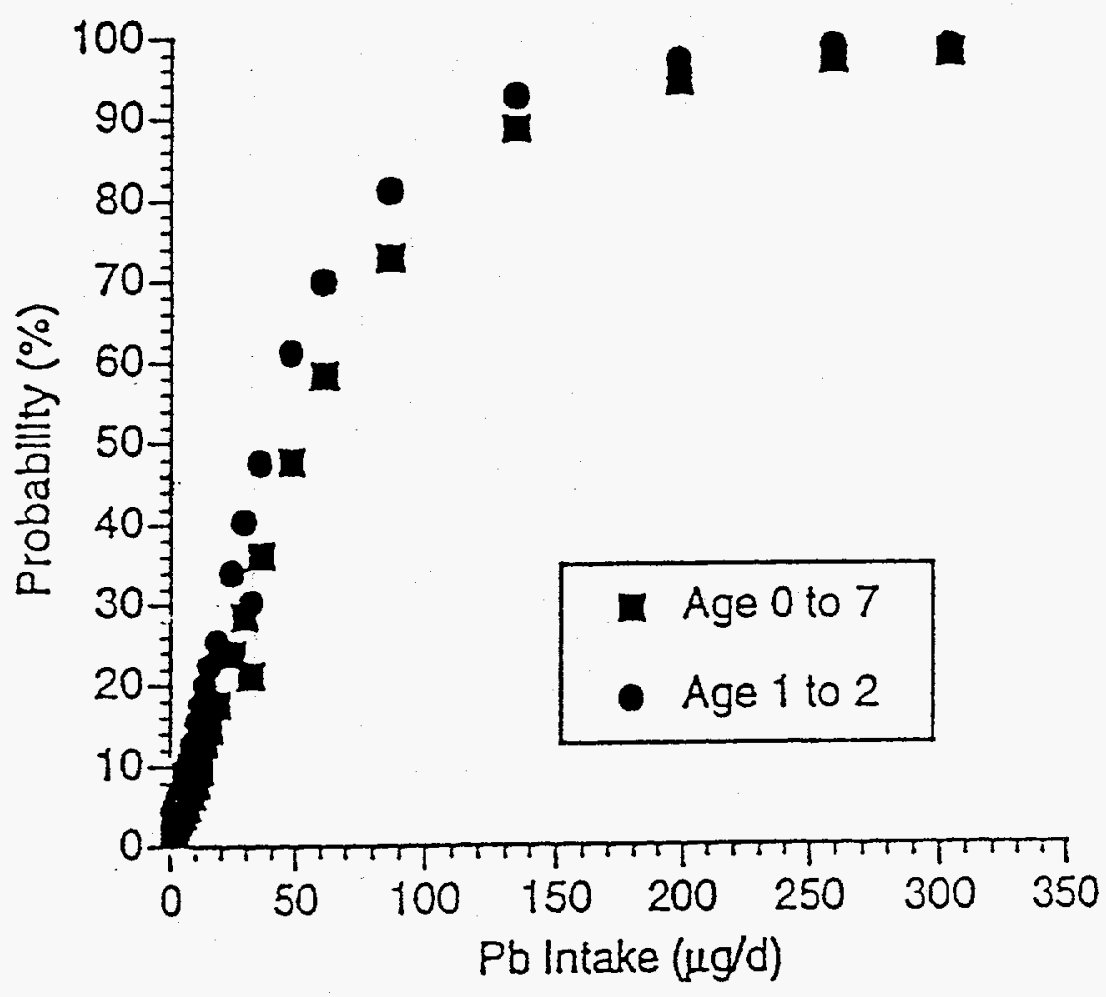




\section{ECOLOGICAL RISK ASSESSMENT FOR METALS, ORGANICS AND TOTAL EFFLUENT}

\subsection{Introduction and Approach}

Three screening analyses were used to identify potential ecological effects and important receptors:

1. Sediment toxicity - Sediment metal and PAH concentrations measured at the Delacroix Island and Bay de Chene USDOE study sites (pretermination data, section 4) were compared to proposed sediment quality criteria;

2. Potential toxicity of individual contaminants in the water column - Worstcase predicted water column concentrations of contaminants measured in continuing open bay effluents (LDEQ permit files, section 5) were compared to USEPA and Louisiana water quality criteria;

3. Total effluent toxicity - Predicted water column concentrations of effluent were compared to results of acute and chronic toxicity tests performed in the laboratory with standard test organisms (LDEQ permit files, section 5).

\subsection{Sediment Toxicity -- USDOE Open Bay Sites}

Marine environments containing high levels of (multiple) contaminants may be associated with adverse effects on biota. However, no direct causal relationship has been established between a contaminant and a biological effect in a marine environment. Therefore, sediment quality criteria rely on prudent use of the best information available and empirical data (E.V.S. Consultants, 1990).

A screening ecological risk assessment was performed, using preliminary data that describe concentrations of heavy metals and PAHs in sediment cores taken at sampling stations at the Delacroix Island and Bay de Chene USDOE study sites (Appendix A). These data were compared to sediment quality criteria (Table 9-1) developed for contaminants in marine and estuarine sediments (Long et al., 1995). These criteria are based on specific levels of probability of toxicological effects that could be related to compilations of a biological effects database (BEDS) for contaminant concentrations in marine and estuarine sediments. The criteria were recently updated, but remain generally consistent with those previously reported (Long and Morgan, 1990).

BEDS includes a wide variety of adverse biological effects and information derived from all the types of measurements described above. Concentrations in 
each study included in BEDS were assigned an effects/no effects descriptor, and ascending orders of concentration were assigned percentile values to describe the distributions. The lower tenth percentile level was identified as the Effects Range Low (ERL) value, and the fiftieth percentile was identified the Effects Range Median (ERM) value. Measured sediment values below the ERL value of a contaminant represent a minimal effects range, where effects "would rarely be observed". Concentrations at and above the ERL value, but less than the ERM value, "represent a possible-effects range within which effects would occasionally occur". Concentrations at or above the ERM value "represent a probable effects range within which effects would frequently occur" (Long et al., 1995).

Tạble 9-1 Proposed sediment quality criteria (from Long et al., 1995).

\begin{tabular}{|c|c|c|}
\hline & \multicolumn{2}{|c|}{ Sediment Quality Criteria } \\
\hline Contaminant & $E^{E} L^{\prime}$ & $\mathrm{ERM}^{2}$ \\
\hline Metals & $(\mathrm{ppm})^{3}$ & $(p p m)^{3}$ \\
\hline Arsenic & 8.2 & 70 \\
\hline Cadmium & 1.2 & 9.6 \\
\hline Chromium & 81 & 370 \\
\hline Copper & 34 & 270 \\
\hline Lead & 46.7 & 218 \\
\hline Mercury & 0.15 & 0.71 \\
\hline Nickel & 20.9 & 51.6 \\
\hline Silver & 1.0 & 3.7 \\
\hline Zinc & 150 & 410 \\
\hline Organics & $(p p b)^{3}$ & $(p p b)^{3}$ \\
\hline Total PCBs & 22.7 & 180 \\
\hline Total PAH & 4022 & 44792 \\
\hline Acenaphthene & 16 & 500 \\
\hline Acenaphthylene & 44 & 640 \\
\hline Anthracene & 85.3 & 1100 \\
\hline Fluorene & 19 & 540 \\
\hline 2-Methylnaphthalene & 70 & 670 \\
\hline Naphthalene & 160 & 2100 \\
\hline Phenanthrene & 240 & 1500 \\
\hline Low Molec. Weight-PAH & 552 & 3160 \\
\hline Benzo(a)anthracene & 261 & 1600 \\
\hline Benzo(a)pyrene & 430 & 1600 \\
\hline Chrysene & 384 & 2800 \\
\hline Dibenzo(a,h)anthracene & 63.4 & 260 \\
\hline Fluoranthene & 600 & 5100 \\
\hline Pyrene & 665 & 2600 \\
\hline High Molec. Weight-PAH & 1700 & 9600 \\
\hline
\end{tabular}


Table 9-2 shows the results of the screening assessment for metals in sediment, and Tables 9-3, 4 and 5 show the results of PAH analyses. None of the measured concentrations of metals in sediment samples exceeded their respective ERM value. In general, measured sediment concentrations were below the ERL (minimal effects range), with the exception of arsenic and nickel. Each of these metals exceeded its ERL value in samples from at least one reference station, and both discharges. Excess arsenic was detected up to 500 $\mathrm{m}$ from the Bay de Chene discharge (Table 9-2). Excess nickel was detected up to $500 \mathrm{~m}$ from the Delacroix Island discharge, and up to $1,000 \mathrm{~m}$ from the Bay de Chene discharge. There was no clear pattern of concentration with distance from a discharge.

Table 9-2. Measured metal concentrations that exceeded ERL sediment criteria (Long et al., 1995), at sampling stations ( 0 to $5 \mathrm{~cm}$ depth) around the Delacroix Islands and Bay de Chene study sites.

\begin{tabular}{|l|c|c|}
\hline & As (ppm) & Ni(ppm) \\
\hline & & \\
\hline ERL & 8.2 & 20.9 \\
\hline Delacroix Island & & \\
\hline R1 & & $25.1^{*}$ \\
\hline R2 & $4.7^{*}$ & $20.0^{*}$ \\
\hline Discharge & $3.6^{*}$ & 22.7 \\
\hline $100 \mathrm{NW}$ & 10.7 & 23.0 \\
\hline $300 \mathrm{NW}$ & & 22.6 \\
\hline $100 \mathrm{NE}$ & & 21.7 \\
\hline $300 \mathrm{NE}$ & & 21.6 \\
\hline $500 \mathrm{NE}$ & & 22.6 \\
\hline & & \\
\hline Bay de Chene' & & \\
\hline R1 & & $20.6^{*}$ \\
\hline R2 & & $21 .^{*}$ \\
\hline Discharge & $8.7^{*}$ & $24.2^{*}$ \\
\hline $100 \mathrm{NW}$ & $7.5^{*}$ & $28.2^{*}$ \\
\hline $300 \mathrm{NW}$ & $11.0^{*}$ & 25.7 \\
\hline $500 \mathrm{NW}$ & $10.4^{*}$ & 23.9 \\
\hline $100 \mathrm{SW}$ & 13.9 & 25.3 \\
\hline $300 \mathrm{SW}$ & 8.7 & 22.8 \\
\hline $1000 \mathrm{SW}$ & & 22.9 \\
\hline $100 \mathrm{NE}$ & & 26.0 \\
\hline
\end{tabular}

sample locations, distance from discharge in meters; $R=$ reference *mean value 
Table 9-3. Sediment samples from the Delacroix Island area that exceeded ERL values (Long et al., 1995) for total and individual PAH concentrations.

\begin{tabular}{|c|c|c|c|c|}
\hline Contaminant & $\begin{array}{c}\text { ERL } \\
\text { (ppb dry weight) }\end{array}$ & $\begin{array}{l}\text { Measured } \\
\text { (ppb dry } \\
\text { weight) }\end{array}$ & Location & $\begin{array}{l}\text { Sediment } \\
\text { Depth } \\
\text { (cm) }\end{array}$ \\
\hline \multirow[t]{7}{*}{ Total PAH } & 4,022 & 9,406 & Discharge & 0 to 5 \\
\hline & & 8,143 & Discharge & 20 to 25 \\
\hline & & 20,065 & Discharge & 0 to 5 \\
\hline & & 6,913 & Discharge & 35 to 40 \\
\hline & & 9,142 & Discharge & 0 to 5 \\
\hline & & 16,401 & Discharge & 20 to 25 \\
\hline & & 6,056 & $100 \mathrm{~m} \mathrm{NW}$ & 0 to 5 \\
\hline \multirow[t]{15}{*}{ Acenaphthene } & 16 & 22 & Discharge & 0 to 5 \\
\hline & & 130 & Discharge & 20 to 25 \\
\hline & & 41 & Discharge & 35 to 40 \\
\hline & & 50 & Discharge & 0 to 5 \\
\hline & & 64 & Discharge & 20 to 25 \\
\hline & & 190 & Discharge & 35 to 40 \\
\hline & & 24 & Discharge & 0 to 5 \\
\hline & & 280 & Discharge & 20 to 25 \\
\hline & & 19 & Discharge & 35 to 40 \\
\hline & & 99 & $100 \mathrm{~m} \mathrm{NW}$ & 0 to 5 \\
\hline & & 180 & $300 \mathrm{~m} \mathrm{NW}$ & 0 to 5 \\
\hline & & 69 & $500 \mathrm{~m} \mathrm{NW}$ & 0 to 5 \\
\hline & & 210 & $100 \mathrm{~m} \mathrm{NE}$ & 0 to 5 \\
\hline & & 71 & $300 \mathrm{~m} \mathrm{NE}$ & 0 to 5 \\
\hline & & 140 & $500 \mathrm{~m} \mathrm{NE}$ & 0 to 5 \\
\hline \multirow[t]{2}{*}{ Anthracene } & 85 & 150 & Discharge & 20 to 25 \\
\hline & & 200 & $100 \mathrm{~m} \mathrm{NW}$ & 0 to 5 \\
\hline \multirow[t]{7}{*}{ Fluorene } & 19 & 53 & Discharge & 0 to 5 \\
\hline & & 83 & Discharge & 20 to 25 \\
\hline & & 100 & Discharge & 0 to 5 \\
\hline & & 48 & Discharge & 20 to 25 \\
\hline & & 58 & Discharge & 35 to 40 \\
\hline & & 50 & Discharge & 0 to 5 \\
\hline & & 76 & Discharge & 20 to 25 \\
\hline \multirow[t]{4}{*}{ Naphthalene } & 160 & 160 & Discharge & 0 to 5 \\
\hline & & 200 & Discharge & 0 to 5 \\
\hline & & 160 & Discharge & 0 to 5 \\
\hline & & 260 & Reference 1 & 35 to 40 \\
\hline \multirow[t]{4}{*}{ Benzo(a)anthracene } & 261 & 320 & Discharge & 20 to 25 \\
\hline & & 350 & Discharge & 35 to 40 \\
\hline & & 1,000 & Discharge & 20 to 25 \\
\hline & & 350 & $100 \mathrm{~m} \mathrm{NW}$ & 0 to 5 \\
\hline
\end{tabular}


Table 9-3. (cont.)

\begin{tabular}{|c|c|c|c|c|}
\hline Contaminant & ERL & $\begin{array}{c}\text { Measured } \\
\text { (ppb dry } \\
\text { weight) }\end{array}$ & Location & $\begin{array}{c}\text { Sediment } \\
\text { Depth } \\
\text { (cm) }\end{array}$ \\
\hline Benzo(a)pyrene & 430 & 470 & Discharge & 20 to 25 \\
\hline Chrysene & 384 & 470 & Discharge & 20 to 25 \\
\hline & & 1,200 & Discharge & 20 to 25 \\
\hline Dibenzo(a,h)anthracene & 63 & 67 & Discharge & 20 to 25 \\
\hline Fluoranthene & 600 & 1,000 & Discharge & 20 to 25 \\
\hline & & 620 & Discharge & 35 to 40 \\
\hline & & 1,400 & Discharge & 35 to 40 \\
\hline & & 3,500 & Discharge & 20 to 25 \\
\hline & & 900 & 100 m NW & 0 to 5 \\
\hline Pyrene & 665 & 2,200 & Discharge & 20 to 25 \\
\hline & & 880 & Discharge & 35 to 40 \\
\hline
\end{tabular}


Table 9-4. Sediment samples from the Bay de Chene area that exceeded ERL values (Long et al., 1995) for total and individual PAH concentrations.

\begin{tabular}{|c|c|c|c|c|}
\hline Contaminant & $\begin{array}{c}\text { ERL } \\
\text { (ppb dry } \\
\text { weight) }\end{array}$ & $\begin{array}{l}\text { Measured } \\
\text { (ppb dry } \\
\text { weight) }\end{array}$ & Location & $\begin{array}{l}\text { Depth } \\
(\mathrm{cm})\end{array}$ \\
\hline \multirow{13}{*}{ Total PAH } & 4022 & 23723 & Discharge & 0 to 5 \\
\hline & & 18003 & Discharge & 20 to 25 \\
\hline & & 35369 & Discharge & 35 to 40 \\
\hline & & 162152 & Discharge & 0 to 5 \\
\hline & & 28980 & Discharge & 20 to 25 \\
\hline & & 49963 & Discharge & 35 to 40 \\
\hline & & 32179 & Discharge & 0 to 5 \\
\hline & & 31482 & Discharge & 20 to 25 \\
\hline & & 43359 & Discharge & 35 to 40 \\
\hline & & 6336 & $300 \mathrm{~m} \mathrm{NE}$ & 0 to 5 \\
\hline & & 5370 & $100 \mathrm{~m} \mathrm{NW}$ & 0 to 5 \\
\hline & & 4075 & $300 \mathrm{~m} \mathrm{NW}$ & 0 to 5 \\
\hline & & 11577 & $100 \mathrm{~m} \mathrm{NE}$ & 0 to 5 \\
\hline \multirow[t]{11}{*}{ Acenaphthene } & 16 & 180 & Discharge & 0 to 5 . \\
\hline & & 69 & Discharge & 20 to 25 \\
\hline & & 99 & Discharge & 35 to 40 \\
\hline & & 210 & Discharge & 0 to 5 \\
\hline & & 71 & Discharge & 20 to 25 \\
\hline & & 140 & Discharge & 35 to 40 \\
\hline & & 250 & Discharge & 0 to 5 \\
\hline & & 110 & Discharge & 20 to 25 \\
\hline & & 140 & Discharge & 35 to 40 \\
\hline & & 48 & $100 \mathrm{~m} \mathrm{NE}$ & 0105 \\
\hline & & 20 & $300 \mathrm{~m} \mathrm{NE}$ & 0 to 5 \\
\hline \multirow[t]{10}{*}{ Anthracene } & 85.3 & 250 & Discharge & 0 to 5 \\
\hline & & 150 & Discharge & 20 to 25 \\
\hline & & 160 & Discharge & 35 to 40 \\
\hline & & 1000 & Discharge & 0 to 5 \\
\hline & & 300 & Discharge & 20 to 25 \\
\hline & & 220 & Discharge & 35 to 40 \\
\hline & & 470 & Discharge & 0 to 5 \\
\hline & & 210 & Discharge & 20 to 25 \\
\hline & & 180 & Discharge & 35 to 40 \\
\hline & & 86 & $100 \mathrm{~m} \mathrm{NE}$ & 0 to 5 \\
\hline \multirow[t]{12}{*}{ Fluorene } & 19 & 230 & Discharge & 0 to 5 \\
\hline & & 130 & Discharge & 20 to 25 \\
\hline & & 240 & Discharge & 35 to 40 \\
\hline & & 390 & Discharge & 0 to 5 \\
\hline & & 150 & Discharge & 20 to 25 \\
\hline & & 350 & Discharge & 35 to 40 \\
\hline & & 340 & Discharge & 0 to 5 \\
\hline & & 210 & Discharge & 20 to 25 \\
\hline & & 320 & Discharge & 35 to 40 \\
\hline & & 22 & $100 \mathrm{~m} \mathrm{NW}$ & 0 to 5 \\
\hline & & 33 & $300 \mathrm{~m} \mathrm{NW}$ & 0 to 5 \\
\hline & & 67 & $100 \mathrm{~m} \mathrm{NE}$ & 0 to 5 \\
\hline
\end{tabular}


Table 9-4. (cont.)

\begin{tabular}{|c|c|c|c|c|}
\hline Contaminant & $\begin{array}{l}\text { ERL } \\
\text { (ppb dry } \\
\text { weight) }\end{array}$ & $\begin{array}{l}\text { Measured } \\
\text { (ppb dry } \\
\text { weight) }\end{array}$ & Location & $\begin{array}{l}\text { Depth } \\
\text { (cm) }\end{array}$ \\
\hline Naphthalene & 160 & 160 & Discharge & 0 to 5 \\
\hline \multirow[t]{11}{*}{ Phenanthrene } & 240 & 890 & Discharge & 0 to 5 \\
\hline & & 300 & Discharge & 20 to 25 \\
\hline & & 600 & Discharge & 35 to 40 \\
\hline & & 1800 & Discharge & 0 to 5 \\
\hline & & 370 & Discharge & 20 to 25 \\
\hline & & 890 & Discharge & 35 to 40 \\
\hline & & 1400 & Discharge & 0 to 5 \\
\hline & & 490 & Dischange & 20 to 25 \\
\hline & & 680 & Discharge & 35 to 40 \\
\hline & & 250 & $100 \mathrm{~m} \mathrm{NE}$ & 0 to 5 \\
\hline & & 260 & $300 \mathrm{~m} \mathrm{NE}$ & 0 to 5 \\
\hline \multirow[t]{10}{*}{ Benzo(a)anthracene } & 261 & 960 & Discharge & 0 to 5 \\
\hline & & 470 & Discharge & 20 to 25 \\
\hline & & 330 & Discharge & 35 to 40 \\
\hline & & 12000 & Discharge & 0 to 5 \\
\hline & & 780 & Discharge & 20 to 25 \\
\hline & & 490 & Discharge & 35 to 40 \\
\hline & & 1400 & Discharge & 0 to 5 \\
\hline & & 760 & Discharge & 20 to 25 \\
\hline & & 340 & $100 \mathrm{~m} \mathrm{NE}$ & 0 to 5 \\
\hline & & 350 & $300 \mathrm{~m} \mathrm{NE}$ & 0 to 5 \\
\hline \multirow[t]{5}{*}{ Benzo(a)pyrene } & 430 & 850 & Discharge & 0 to 5 \\
\hline & & 9000 & Discharge & 0 to 5 \\
\hline & & 530 & Discharge & 20 to 25 \\
\hline & & 1200 & Discharge & 0 to 5 \\
\hline & & 650 & Discharge & 20 to 25 \\
\hline \multirow[t]{9}{*}{ Chrysene } & 384 & 1000 & Discharge & 0 to 5 \\
\hline & & 600 & Discharge & 20 to 25 \\
\hline & & 470 & Discharge & 35 to 40 \\
\hline & & 11000 & Discharge & 0 to 5 \\
\hline & & 790 & Discharge & 20 to 25 \\
\hline & & 600 & Discharge & 35 to 40 \\
\hline & & 1300 & Discharge & 0 to 5 \\
\hline & & 820 & Discharge & 20 to 25 \\
\hline & & 470 & $100 \mathrm{~m} \mathrm{NE}$ & 0105 \\
\hline \multirow[t]{8}{*}{ Dibenzo $(a, h)$ anthracene } & 63.4 & 150 & Discharge & 0105 \\
\hline & & 78 & Discharge & 20 to 25 \\
\hline & & 1700 & Discharge & 0105 \\
\hline & & 95 & Discharge & 20 to 25 \\
\hline & & 83 & Discharge & 351040 \\
\hline & & 210 & Discharge & 0 to 5 \\
\hline & & 130 & Discharge & 201025 \\
\hline & & 70 & $100 \mathrm{~m} \mathrm{NE}$ & 0 to 5 \\
\hline
\end{tabular}


Table 9-4 (cont.)

\begin{tabular}{|c|c|c|c|c|}
\hline Contaminant & $\begin{array}{c}\text { ERL } \\
\text { (ppb dry } \\
\text { weight) }\end{array}$ & $\begin{array}{c}\text { Measured } \\
\text { (ppb dry } \\
\text { weight) }\end{array}$ & Location & $\begin{array}{c}\text { Depth } \\
\text { (cm) }\end{array}$ \\
\hline Fluoranthene & 600 & 2100 & Discharge & 0 to 5 \\
\hline & & 1000 & Discharge & 20 to 25 \\
\hline & & 780 & Discharge & 35 to 40 \\
\hline & & 8100 & Discharge & 0 to 5 \\
\hline & & 1300 & Discharge & 20 to 25 \\
\hline & & 1200 & Discharge & 35 to 40 \\
\hline & & 2700 & Discharge & 0 to 5 \\
\hline & & 1700 & Discharge & 20 to 25 \\
\hline & & 800 & Discharge & 35 to 40 \\
\hline & & 910 & 100 m NE & 0 to 5 \\
\hline & & 650 & 300 m NE & 0 to 5 \\
\hline & 1500 & Discharge & 0 to 5 \\
\hline & 665 & 810 & Discharge & 20 to 25 \\
\hline & & 6100 & Discharge & 0 to 5 \\
\hline & & 940 & Discharge & 20 to 25 \\
\hline & & 960 & Discharge & 35 to 40 \\
\hline & & 1900 & Discharge & 0 to 5 \\
\hline & & 1300 & Discharge & 20 to 25 \\
\hline & & 730 & 100 m NE & 0 to 5 \\
\hline & & & & \\
\hline & & & &
\end{tabular}


With the exception of acenaphthene, individual and total PAH concentrations exceeded ERL criteria at, and $100 \mathrm{~m}$ from the discharge at Delacroix Island (Table 9-3). Acenaphthene concentrations exceeded the ERL values at the discharge, 100,300 and $500 \mathrm{~m}$ stations. Neither individual nor total PAH concentrations in sediment samples from Delacroix Island exceeded ERM criteria.

Individual and total PAH concentrations exceeded ERL criteria at the discharge, and $100 \mathrm{~m}$ and $300 \mathrm{~m}$ from the discharge at Bay de Chene (Table 9-4).

Individual and total PAH concentrations in samples from the discharge sediment exceeded ERM criteria (Table 9-5).

Table 9-5. PAH concentrations in marine sediments (dry weight) at Bay de Chene that exceed ERM concentrations.

\begin{tabular}{|l|r|r|r|c|}
\hline \multicolumn{1}{|c|}{ Contaminant } & $\begin{array}{c}\text { ERM } \\
\text { (ppb) }\end{array}$ & \multicolumn{1}{|c|}{$\begin{array}{c}\text { Measured } \\
\text { (ppb) }\end{array}$} & Location & $\begin{array}{c}\text { Sediment Depth } \\
\text { (cm) }\end{array}$ \\
\hline Total PAH & & & & 0 \\
\hline & 44,792 & 162,152 & Discharge & 0 to 5 \\
\hline & & 49,963 & Discharge & 35 to 40 \\
\hline Benzo(a)anthracene & & & & 0 to 5 \\
\hline Benzo(a)pyrene & 1,600 & 12,000 & Discharge & 0 to 5 \\
\hline Chrysene & 1,600 & 9,000 & Discharge & 0 to 5 \\
\hline Dibenzo(a,h)anthracene & 2,800 & 11,000 & Discharge & 0 to 5 \\
\hline Fluoranthene & 260 & 1,700 & Discharge & 0 to 5 \\
\hline Pyrene & 5,100 & 8,100 & Discharge & 0 to 5 \\
\hline & 2,600 & 6,100 & Discharge & \\
\hline High Molecular Weight PAH & & & & \\
\hline
\end{tabular}

The field studies showed depression of numbers of species (amphipod, gastropod, bivalve, and polychaetes) and/or individuals at less than $100 \mathrm{~m}$ from the discharges (Mulino et al., 1995; 1996). The pre-termination benthic effects were greater at the Delacroix Island discharge station than at the comparable Bay de Chene station. Mulino et al. $(1995 ; 1996)$ explained this on the basis of hydrology of the environment. Although the Delacroix discharge was approximately half that at Bay de Chene, there was less opportunity for turbulent mixing and dilution of the discharge because the Delacroix environment was semi-enclosed. It was suggested that the Delacroix discharge was more likely to produce a hypersaline nonoxygenated layer on the bottom, as supported by data on the chlorinity of pore water from the 2 sites.

Mulino et al. (1996) did a stepwise multiple regression analysis to look for correlations of PAH concentrations at the stations with benthic biota data. Fluoranthene at Bay de Chene was the only PAH, of those exceeding the criteria values in Tables 9-3 and 9-4, that showed a negative correlation with the benthic 
data. Dibenzothiophene was the only other PAH that exhibited a (negative) correlation with the benthic biota data.

These results cannot be applied to all other open bay discharge sites with much confidence, but the pre-termination discharge rates and depths of the Bay de Chene and Delacroix Island study sites are comparable (discharge rates are on the high end of distribution) to those that are continuing to discharge (see section 5). Although the benthic survey does not validate the comparisons to the screening criteria, there is no reason to expect such a validation (Chapman, $1995 a, b)$. Screening criteria for the individual chemicals in this case can only indicate potential ecological problems, while field surveys present the effects on biota of the total set of conditions at the time of sampling. Nevertheless, there is good general agreement between the results of the screening assessment with the observations of the field surveys.

\subsection{Toxicity of Individual Produced Water Components - Continuing Open Bay Discharges}

\subsubsection{Screening Analysis}

A screening analysis was performed for potential toxic effects from individual contaminants in plumes from continuing open bay discharges. Average and worst-case concentrations of contaminants measured in the discharges (LDEQ permit files) were used to predict water column concentrations. The predicted concentrations were then compared to USEPA and Louisiana water quality criteria.

Concentrations in the discharges were described by data abstracted from LDEQ permit files (section 5). These data contain only values for contaminants detected in the effluent above the reported detection limit, and therefore overestimate average concentrations.

In this preliminary assessment, contaminants were assessed only if: they were reported above detection limits in more than two of the LDEQ permit files; and water quality criteria were available. Mean and maximum chemical contaminant concentrations in the data set for continuing open bay discharges were diluted by a factor of 20 to estimate water concentrations in a plume (Table 9-6). A dilution factor of 20 was chosen to estimate worst-case concentrations because it yields more conservative concentrations than those predicted by the CORMIX model (section 5) at 50 and 200 feet from the discharge. Although most contaminants were assumed to remain totally in solution, dissolved fractions of copper. lead and zinc were assumed to be $0.88,0.38$ and 0.59 , respectively (USEPA, 1995a). 
Louisiana and USEPA water quality criteria (Table 9-6) were compared to the predicted water concentrations. Ratios were calculated for each contaminant by dividing the concentration predicted in water by the contaminant's acute and chronic water quality criteria. These ratios are here called the Acute Hazard quotient (AHQ) and Chronic Hazard Quotients (CHQ), respectively. Hazard quotients greater than 1 suggest a potential for toxic effects. Results are given in Tables 9-7 and 9-8. Acute criteria were used as standards for LDEQ's mandated toxicity determinations at 50 feet, while chronic criteria were used as standards for LDEQ's mandated determinations at 200 feet.

Table 9-6. Screening concentrations of chemicals, and water quality criteria at 50 feet (acute) and 200 feet (chronic) from open bay discharges.

\begin{tabular}{|c|c|c|c|c|c|c|}
\hline \multirow[t]{2}{*}{ Contaminant } & \multicolumn{2}{|c|}{$\begin{array}{c}\text { Predicted } \\
\text { Concentration }(\mu \mathrm{g} / \mathrm{l})\end{array}$} & \multicolumn{2}{|c|}{$\begin{array}{c}\text { Acute Water } \\
\text { Quality Criteria }(\mu \mathrm{g} / \mathrm{l})\end{array}$} & \multicolumn{2}{|c|}{$\begin{array}{c}\text { Chronic Water } \\
\text { Quality Criteria ( } \mu \text { g/l) }\end{array}$} \\
\hline & mean & maximum & LDEQ & USEPA & LDEQ & USEPA \\
\hline Antimony & 279.8 & 1005 & $\overline{-}$ & 1500 & - & 500 \\
\hline Arsenic & 3.7 & 24.9 & 69 & 69 & 36 & 36 \\
\hline Cadmium & 11.6 & 25.0 & 45.6 & 43 & 10 & 9.3 \\
\hline Chromium (VI) & 4.2 & 10.0 & 1100 & 1100 & 50 & 50 \\
\hline Copper & 12.7 & 31.2 & 4.37 & 2.9 & 4.37 & - \\
\hline Lead & 1981.0 & 15751 & 220 & 140 & 8.5 & 5.6 \\
\hline Mercury & 0.4 & 1.4 & 2.1 & 2.1 & 0.025 & 0.025 \\
\hline Nickel & 50.7 & 142 & 75 & 75 & 8.3 & 8.3 \\
\hline Silver & 7.2 & 20.0 & - & 7.2 & - & 0.92 \\
\hline Zinc & 35.9 & 188.1 & $\overline{95}$ & 95 & 86 & 86 \\
\hline Benzene & 90.7 & 477.5 & 2700 & 5100 & 1350 & 700 \\
\hline Naphthalene & 3.0 & 5.9 & - & 2300 & - & - \\
\hline Phenol & 77.9 & 600 & 580 & 5800 & 290 & - \\
\hline Toluene & 41.6 & 140 & 950 & 6300 & 475 & 5000 \\
\hline
\end{tabular}

USEPA's water quality criteria for metals are generally equal to, or lower (more conservative) than, those of LDEQ. LDEQ's criteria for organic chemicals may be up to an order of magnitude more conservative than those of USEPA. Only USEPA's chronic toxicity criterion for benzene is more conservative than that of LDEQ.

Worst-case predicted water concentrations exceeded acute water quality criteria for copper, lead, nickel, silver and zinc (Table 9-7). The mean concentration of copper exceeded acute criteria approximately 3 to 4 fold, while the maximum concentration exceeded these criteria by 7 to 11 fold. The mean concentration of lead was approximately one order of magnitude higher than acute criteria, while the maximum concentration was approximately seventy times to slightly more than one order of magnitude higher than acute criteria. Acute criteria values were exceeded two fold by the predicted maximum concentrations of nickel and zinc. Mean and maximum silver concentrations were 2 and 3 times higher than the USEPA acute criterion. Only the maximum concentration of 
phenol equaled LDEQ's acute criterion value (one order of magnitude lower than that of USEPA).

Table 9-7. Screening-level Acute Hazard Quotients (AHQ): predicted concentrations at 50 feet acute water quality criteria (shaded values are those that exceed 1).

\begin{tabular}{|c|c|c|c|c|}
\hline \multirow[t]{2}{*}{ Contaminant } & \multicolumn{2}{|c|}{$\begin{array}{c}\text { AHQ based on LDEQ Water } \\
\text { Quality Criteria }\end{array}$} & \multicolumn{2}{|c|}{$\begin{array}{c}\text { AHQ based on USEPA Wate } \\
\text { Quality Criteria }\end{array}$} \\
\hline & mean & maximum & mean & maximum \\
\hline Antimony & - & - & 0.2 & 0.7 \\
\hline Arsenic & 0.1 & 0.4 & 0.1 & 04 \\
\hline Cadmium & 0.3 & 0.6 & 0.3 & 0.6 \\
\hline Chromium (VI) & 0.004 & 0.01 & 0.004 & 0.01 \\
\hline Copper & zy. & x & 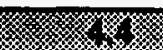 & 等管 \\
\hline Lead & $x_{3}$ & zk & x.m. & 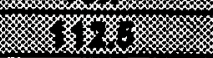 \\
\hline Mercury & 0.2 & 0.6 & 0.2 & 0.6 \\
\hline Nickel & 0.7 & 站 & 0.7 & . \\
\hline Silver & - & - & 桨 & sis \\
\hline Zinc & 0.4 & 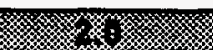 & 0.4 & 2.0 \\
\hline Benzene & 0.03 & 0.2 & 0.02 & 0.1 \\
\hline Naphthalene & - & - & 0.001 & 0.002 \\
\hline Phenol & 0.1 & 1.0 & 0.01 & 0.1 \\
\hline Toluene & 0.04 & 0.2 & 0.01 & 0.02 \\
\hline
\end{tabular}

Table 9-8. Screening-level Chronic Hazard Quotients (CHQ): predicted concentrations at 200 feet / acute water quality criteria (shaded values are those that exceed 1).

\begin{tabular}{|c|c|c|c|c|}
\hline \multirow[t]{2}{*}{ Contaminant } & \multicolumn{2}{|c|}{$\begin{array}{c}\text { CHQ based on LDEQ Water } \\
\text { Quality Criteria }\end{array}$} & \multicolumn{2}{|c|}{$\begin{array}{l}\text { CHQ based on USEPA } \\
\text { Water Quality Criteria }\end{array}$} \\
\hline & mean & maximum & mean & maximum \\
\hline & & & & \\
\hline Antimony & - & - & 0.6 & sis \\
\hline Arsenic & 0.1 & 0.7 & 0.1 & 0.7 \\
\hline Cadmium & $x$ & Xns. & $x$ & 3 \\
\hline Chromium (VI) & 0.1 & 0.20 & 0.1 & 0.2 \\
\hline Copper & 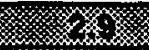 & 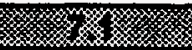 & - & - \\
\hline Lead & $x+5$ & 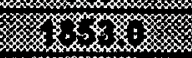 & shom & Xn \\
\hline Mercuny & W. & 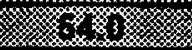 & . & x. \\
\hline Nickel & - & W & Kris & K \\
\hline Silver & - & - & 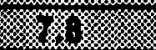 & s \\
\hline Zinc & 0.4 & xy & 0.4 & $x$ \\
\hline Benzene & 0.1 & 0.4 & 0.1 & 0.7 \\
\hline Naphthalene & - & - & - & $\cdots$ \\
\hline Phenol & 0.3 & 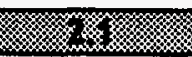 & - & -- \\
\hline Toluene & 0.1 & 0.3 & 0.01 & 0.03 \\
\hline
\end{tabular}


Chronic water quality criteria were exceeded by predicted concentrations of antimony, cadmium, mercury, and the contaminants that exceeded acute toxicity criteria. The maximum concentration of antimony was twice the USEPA's chronic toxicity criterion. Mean and maximum concentrations of cadmium were approximately 1 and 3 times the water quality criteria of both USEPA and LDEQ. LDEQ's acute toxicity criterion is the only available value copper, and that criterion was exceeded by predicted mean and maximum concentrations by approximately 3 and 7 times. Lead concentrations exceeded chronic criteria values from more than 2 to more than 3 orders of magnitude. USEPA and LDEQ use the same chronic toxicity criteria for each of mercury, nickel, and zinc. Predicted mean and maximum concentrations of mercury respectively exceeded the chronic toxicity criterion by 14 and 54 times. Predicted mean and maximum concentrations of nickel respectively exceeded the chronic toxicity criterion by 6 and 17 times. The predicted maximum concentration of zinc was approximately twice the chronic toxicity criterion. Phenol was the only organic chemical to exceed LDEQ's chronic toxicity criterion; by a factor of two at the predicted maximum concentration.

Because of the conservative nature of this screening analysis, no important effect on aquatic biota can be assumed. Major uncertainties and conservative assumptions in this screening assessment included:

- use of worst-case water concentrations;

- use of average chemical concentrations that excluded zero values; and

- simple comparison to water quality criteria with no reference to specific receptors or end-points of concern in open Louisiana bays.

These analyses serve to eliminate contaminants that do not warrant further time and attention. Arsenic, chromium, benzene, naphthalene and toluene were eliminated from further consideration. Ratios of one to chronic water quality were exceeded by less than an order of magnitude for cadmium, zinc, and phenol. Copper, lead, mercury, nickel, and silver concentrations exceeded chronic water quality criteria by more than an order of magnitude.

Contaminants that exceeded chronic water quality criteria (AHQ or CHQ greater than 1) were assessed in a quantitative risk assessment.

\subsubsection{Quantitative Risk Assessment}

For contaminants not eliminated by the initial screening assessment, permit data (Table 9-9) were used to develop distributions of concentrations in produced water discharges. Contaminants that were not detected were assigned one-half the reported detection limit value. Each contaminant, except cadmium and copper, was assigned a lognormal distribution, after a log probability plot of the frequency of measured values fit a straight line (Layton et al., 1987). Cadmium 
and copper were assigned custom distributions that matched the relative frequencies of their respective values.

Table 9-9. Distributions of concentrations of contaminants $(\mu \mathrm{g} / \mathrm{l})$ found in discharges from open bay platforms.

\begin{tabular}{|l|l|c|c|c|c|}
\hline Contaminant & Distribution & Mean & SD & Minimum & Maximum \\
\hline & & & & & \\
\hline Antimony & Lognormal & 3192.6 & 6268.3 & 11.8 & 20,100 \\
\hline Cadmium & Custom & 217.9 & 235.6 & 0.0015 & 540 \\
\hline Copper & Custom & 227.8 & 208 & 5 & 710 \\
\hline Lead & Lognormal & 546.8 & 934.4 & 25 & 2600 \\
\hline Mercury & Lognormal & 4.3 & 11.1 & 0.0005 & 41 \\
\hline Nickel & Lognormal & 569.1 & 947.9 & 20 & 2,480 \\
\hline Silver & Lognormal & 88.8 & 118 & 5 & 400 \\
\hline Zinc & Lognormal & 1465.3 & 2768.3 & 2.5 & 10,800 \\
\hline Phenol & Lognormal & 1257.3 & 2743.4 & 5 & 12,000 \\
\hline & & & & & \\
\hline
\end{tabular}

These distributions were used with the relationships established by the CORMIX algorithms to obtain concentrations of each chemical at 200 feet in the plume (see section 5-3). The concentrations at 200 feet (Table 9-10) accounted for fractional solubility of each chemical in water (Table 8-1): 1 for all chemicals, with the exception of: 0.88 for copper; 0.38 for lead; and 0.59 for zinc. The assessment was performed for $200 \mathrm{ft}$ because this is the chronic mixing zone under LDEQ's regulations, and limitations on the ability of CORMIX to generate concentrations at the acute mixing zone (see section 5).

The distributions of predicted chemical concentrations were then used in probabilistic analyses of potential toxicity to biota. These distributions were compared to acute and chronic toxicity criteria for marine biota (Table 9-6). The comparisons were expressed as ratios (Table 9-11). None of the predicted chemical concentrations (200 ft) exceeded their respective acute toxicity criteria.

Antimony, phenol, and zinc concentrations did not exceed any of their respective chronic toxicity criteria. With the exception of mercury, none exceeded chronic toxicity criteria by an order of magnitude (Table 9-11). The distributions of ratios were then used to determine the probabilities of exceeding the criteria values (Table 9-12., Figure 9-1). 
Table 9-10. Predicted concentrations of contaminants $(\mu \mathrm{g} / 1)$ in plumes, at 200 feet from discharges of produced waters.

\begin{tabular}{|l|c|c|c|c|}
\hline Contaminant & Mean & SD & Minimum & Maximum \\
\hline & & & & \\
\hline Antimony & 1.8 & 2.2 & 0.02 & 13.4 \\
\hline Cadmium & 0.5 & 1.3 & $9.2 \times 10^{-6}$ & 13.2 \\
\hline Copper & 0.5 & 1.2 & $1.0 \times 10^{-5}$ & 13.6 \\
\hline Lead & 0.5 & 1.1 & $2.0 \times 10^{-3}$ & 12.9 \\
\hline Mercury & 0.01 & 0.03 & $3.6 \times 10^{-6}$ & 0.6 \\
\hline Nickel & 1.4 & 3.3 & $3.9 \times 10^{-3}$ & 52.2 \\
\hline Silver & 0.2 & 0.5 & $2.8 \times 10^{-4}$ & 7.5 \\
\hline Zinc & 0.5 & 0.4 & 0.007 & 4.2 \\
\hline Phenol & 3.3 & 9.7 & 0.01 & 170.0 \\
\hline
\end{tabular}

Table 9-11. Chronic Toxicity Hazard Quotients (CHQ) ratios of contaminant concentrations to water quality criteria for chronic toxicity.

\begin{tabular}{|l|c|c|c|c|}
\hline Contaminant & Average CHQ & Median CHQ & SD & Maximum \\
\hline & & & & \\
\hline Antimony & $1.3 \times 10^{-4}$ & $4.1 \times 10^{-5}$ & $3.3 \times 10^{-4}$ & $5.8 \times 10^{-3}$ \\
\hline Cadmium & 0.06 & 0.01 & 0.14 & 1.42 \\
\hline Copper & 0.12 & 0.03 & 0.27 & 3.11 \\
\hline Lead & 0.12 & 0.04 & 0.26 & 2.93 \\
\hline Mercury & 0.40 & 0.01 & 1.29 & 23.20 \\
\hline Nickel & 0.16 & 0.06 & 0.40 & 6.29 \\
\hline Silver & 0.24 & 0.10 & 0.54 & 8.17 \\
\hline Zinc & $5.8 \times 10^{-3}$ & $3.1 \times 10^{-3}$ & $7.3 \times 10^{-3}$ & $4.9 \times 10^{-2}$ \\
\hline Phenol & $1.1 \times 10^{-2}$ & $3.3 \times 10^{-3}$ & $3.3 \times 10^{-2}$ & $5.9 \times 10^{-1}$ \\
\hline & & & & \\
\hline
\end{tabular}

Table 9-12. Contaminants with concentrations at 200 feet that were $\geq$ chronic toxicity criteria for marine organisms, and percent probability of exceeding those criteria.

\begin{tabular}{|l|c|}
\hline Contaminant & \%p(CHQ) $\geq 1$ \\
\hline & \\
\hline Cadmium & 0.7 \\
\hline Copper & 1.5 \\
\hline Lead & 1.8 \\
\hline Mercury & 9.2 \\
\hline Nickel & 2.1 \\
\hline Silver & 4.8 \\
\hline
\end{tabular}


Figure 9-1. Distribution of chronic hazard quotients $(\mathrm{CHQ})$ for contaminants that have a $\mathrm{CHQ} \geq 1$.

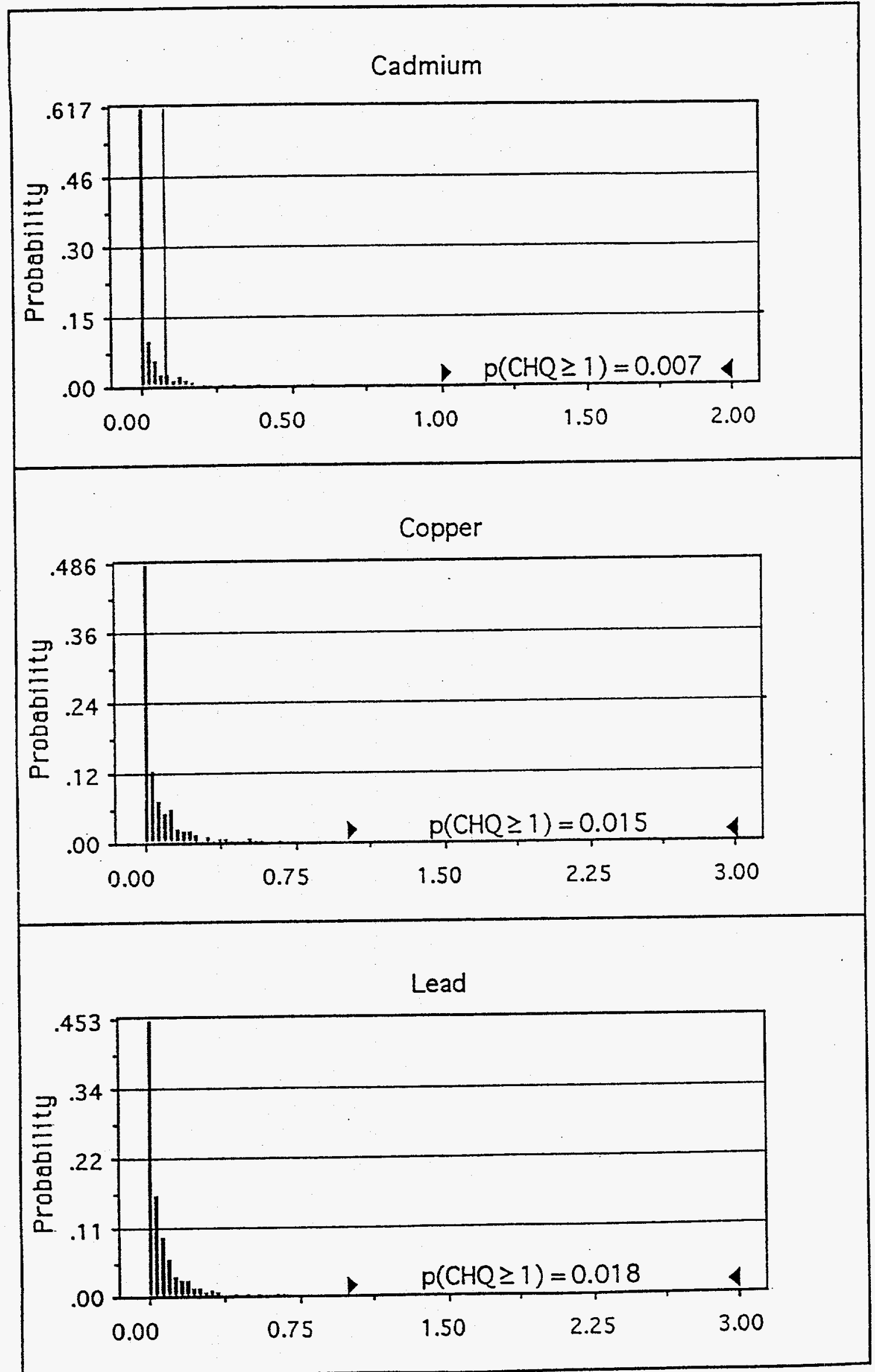


Figure 9-1. (cont.)

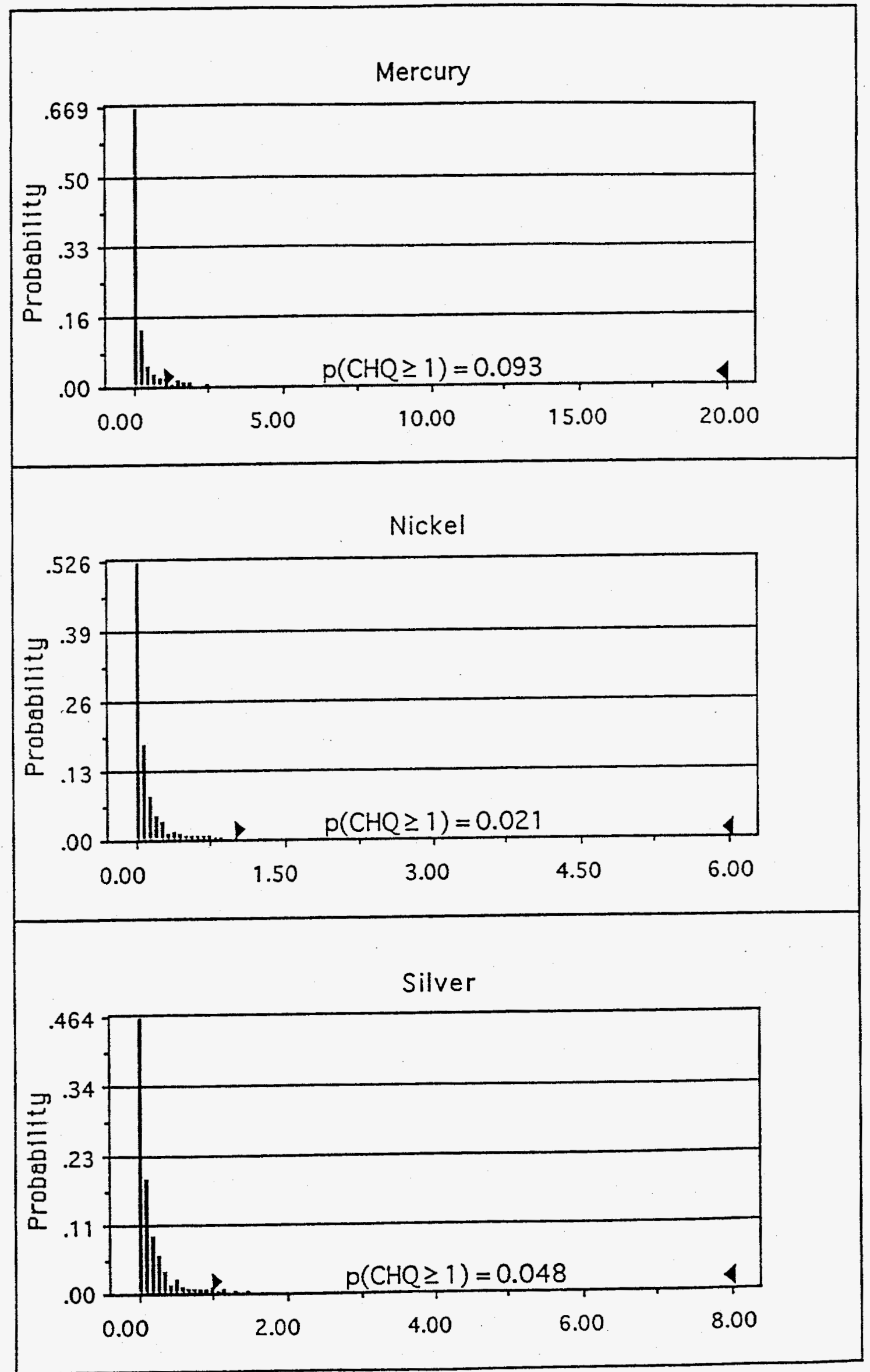


The predicted values in Table 9-9 represent modeled concentrations of chemicals that would be found at midlines of plumes at $200 \mathrm{ft}(\sim 61 \mathrm{~m})$ from discharges of produced water. None of the discharges included in the model yielded concentrations that exceeded acute toxicity criteria at 200 feet. With the exception of mercury, less than five percent of the concentrations of each contaminant, at $200 \mathrm{ft}$, are expected to result in chronic toxicity to biota. More than $90 \%$ of the predicted concentrations of mercury are expected to be below its chronic toxicity criterion.

Physical-chemical properties are not accounted for and it is assumed that components of produced water discharges stay in solution in their plumes, and are freely available to biota. For example, predicted lead concentrations in the water column appear to most greatly exceed acute and chronic toxicity criteria. Under the ordinarily alkaline conditions of briny waters, such as those that might be found in open bays, lead would be expected to form insoluble salts and complexes that tend to precipitate. Thus, metals might not be readily be available to biota in the water. Since these all represent midline values for the plumes, the expectation would be that environmental impacts of the individual chemicals would be limited. However, produced waters are complex mixtures of contaminants that may have a range of interactions from no toxicity to high toxicity. Therefore, the next step was an analysis of actual toxicity testing of diluted whole effluents from produced water discharges (section 9.4).

\subsubsection{Relationships between the Screening and Probabilistic Assessments of Individual Components}

In the screening assessment, a total of nine individual chemicals exceeded chronic toxicity criteria at $200 \mathrm{ft}$. Lead, mercury, nickel and silver exceeded oneor-more of the criteria by at least one order of magnitude. In the quantitative assessment, these chemicals had a $1.8 \%$ to $9.2 \%$ probability of exceeding at least one chronic criterion. Cadmium and copper exceeded one-or-more chronic toxicity criteria by less than an order of magnitude in the screening assessment, and respectively had a $0.7 \%$ and $1.5 \%$ probability of exceeding at least one criterion in the quantitative assessment. In the screening results, antimony, zinc, and phenol exceeded at least one chronic criterion approximately two fold, but did not exceed any criteria in the probabilistic assessment. This suggests that cadmium, copper, lead, mercury, nickel and silver may serve as sentinels for potential toxicity of produced water effluents.

\subsection{Toxicity of Whole Effluents -- Continuing Open Bay Discharges}

Toxicity tests are useful analytical tools because they can directly measure potential aquatic effects. This is particularly true in the case of complex effluents, such as produced water, where a broad range of toxicants can be present at low levels. 
Toxicity test data in LDEQ permit files for assumed continuing discharge sites are summarized in section 5 . The estimated distribution of percent effluent expected at $50 \mathrm{ft}(\sim 15 \mathrm{~m}$; LDEQ acute standard mixing zone) and 200 feet ( 61 $\mathrm{m}$; LDEQ chronic mixing zone) for the continuing discharges in open bays is given in Table 5-8.

For flow rates reported to the LDEQ, previously described relationships between discharge (flow) rates and dilution factors (section 5.3) were used to estimate concentrations of effluents at $50 \mathrm{~m}$ and $200 \mathrm{~m}$ from discharges (Table 9-13).

Standard laboratory test organisms, an amphipod (Mysidopsis bahia) and the sheepshead minnow (Cyprinodon variegatus), were used in toxicity tests that were reported in LDEQ permits. Predicted water column concentrations of effluents were compared with reported results of acute and chronic toxicity tests on diluted effluent samples. For the results of each type of toxicity test, data were expressed in the same way as the predicted water column concentrations: as percent effluent.

Produced water test procedures usually measure mortality responses, with results of acute tests expressed as an effluent median lethal concentration for an exposure duration of $96 \mathrm{hrs}\left(96-\mathrm{hr} \mathrm{LC}_{50}\right.$ ), or the effluent concentration which results in the mortality of $50 \%$ of the test organisms in a 96-hr exposure period. Acute toxicity ratios (AHQ) were calculated between the estimated percent effluent at $50 \mathrm{ft}$ and $200 \mathrm{ft}$ from the discharge and the available corresponding $L C_{50}$ values ( $M$. bahia; $C$. variegatus) for each platform (Tables 9-14, 9-15). Ratios of one or greater indicate potential lethality to each species.

Approximately 3 to 6 times more of the predicted effluent concentrations equaled or exceeded $L C_{50}$ values for $M$. bahia than for $C$. variegatus. At $50 \mathrm{ft}, 15 \%$ of the modeled effluent concentrations exceeded their respective $L_{50}$ values for $M$. bahia, and $5 \%$ exceeded their respective $L C_{50}$ values for $C$. variegatus (Table $9-14)$. A $200 \mathrm{ft}, 15 \%$ of the modeled effluent concentrations exceeded their respective $L C_{50}$ value for $M$. bahia and $2.5 \%$ exceeded their respective $L C_{50}$ value for $C$. variegatus (Table 9-15). These results suggest a potential for lethal effects for some discharges at 50 and at 200 feet.

The data in tables 9-14 and 9-15 suggest that a specific component, or group of components in the effluent from platform 2072 is responsible for the toxicity to $C$. variegatus. The AHQ at $200 \mathrm{ft}$ is relatively high, without any comparable toxicity to the more sensitive $M$. bahia. This is further supported by the CHQ results. 
Table 9-13. Estimated effluent dilutions and concentrations at open bay discharges near the Louisiana coast (BPD $=$ barrels per day).

\begin{tabular}{|c|c|c|c|c|c|}
\hline Platform Site & $\begin{array}{c}\text { Flow Rate } \\
\text { BPD }\end{array}$ & $\begin{array}{l}\text { Dilution } \\
\text { at } 50 \mathrm{ft}\end{array}$ & $\begin{array}{l}\text { \% Effluent } \\
\text { at } 50 \mathrm{ft}\end{array}$ & $\begin{array}{l}\text { Dilution } \\
\text { at } 200 \mathrm{ft}\end{array}$ & $\begin{array}{l}\text { \% Effluent } \\
\text { at } 200 \mathrm{ft}\end{array}$ \\
\hline 2856 & 3 & 4102.6 & 0.0244 & 16378.0 & 0.0061 \\
\hline 3023 & 3.4 & 3680.8 & 0.0272 & 14549.3 & 0.0069 \\
\hline \multirow[t]{2}{*}{2479} & 10 & 1444.8 & 0.0692 & 5243.6 & 0.0191 \\
\hline & 10 & 1444.8 & 0.0692 & 5243.6 & 0.0191 \\
\hline \multirow[t]{2}{*}{2857} & 10 & 1444.8 & 0.0692 & 5243.6 & 0.0191 \\
\hline & 10 & 1444.8 & 0.0692 & 5243.6 & 0.0191 \\
\hline \multirow[t]{4}{*}{3032} & 25 & 652.9 & 0.1532 & 2203.9 & 0.0454 \\
\hline & 30 & 557.4 & 0.1794 & 1854.7 & 0.0539 \\
\hline & 30 & 557.4 & 0.1794 & 1854.7 & 0.0539 \\
\hline & 41 & 425.2 & 0.2352 & 1380.2 & 0.0725 \\
\hline \multirow[t]{2}{*}{1870} & 49 & 364.3 & 0.2745 & 1166.1 & 0.0858 \\
\hline & 117 & 171.3 & 0.5837 & 511.9 & 0.1954 \\
\hline 2915 & 130 & 156.4 & 0.6395 & 463.3 & 0.2158 \\
\hline 2816 & 140 & 146.6 & 0.6819 & 431.9 & 0.2315 \\
\hline \multirow[t]{3}{*}{2881} & 204 & 105.8 & 0.9451 & 302.5 & 0.3306 \\
\hline & 220 & 99.1 & 1.0090 & 281.7 & 0.3550 \\
\hline & 489 & 49.6 & 2.0165 & 132.3 & 0.7558 \\
\hline \multirow[t]{9}{*}{2816} & 510 & 47.8 & 2.0914 & 127.1 & 0.7865 \\
\hline & 600 & 41.5 & 2.4078 & 109.0 & 0.9172 \\
\hline & 614 & 40.7 & 2.4564 & 106.7 & 0.9374 \\
\hline & 701 & 36.3 & 2.7554 & 94.1 & 1.0626 \\
\hline & 729 & 35.1 & 2.8505 & 90.7 & 1.1027 \\
\hline & 802 & 32.3 & 3.0964 & 82.9 & 1.2069 \\
\hline & 1103 & 24.5 & 4.0816 & 61.3 & 1.6316 \\
\hline & 1201 & 22.8 & 4.3942 & 56.5 & 1.7684 \\
\hline & 2065 & 14.2 & 7.0294 & 33.9 & 2.9528 \\
\hline \multirow[t]{2}{*}{2084} & 2484 & 12.1 & 8.2502 & 28.4 & 3.5167 \\
\hline & 2485 & 12.1 & 8.2531 & 28.4 & 3.5180 \\
\hline 2825 & 2910 & 10.6 & 9.4636 & 24.5 & 4.0847 \\
\hline \multirow[t]{3}{*}{2898} & 3000 & 10.3 & 9.7168 & 23.8 & 4.2041 \\
\hline & 3017 & 10.2 & 9.7645 & 23.7 & 4.2267 \\
\hline & 3720 & 8.5 & 11.7086 & 19.4 & 5.1529 \\
\hline 2523 & 5364 & - & - & 52.0 & 1.9218 \\
\hline 2860 & 6800 & -- & - & 43.4 & 2.3024 \\
\hline 2672 & 8366 & - & - & 37.1 & 2.6962 \\
\hline 1901 & 10123 & - & - & 32.1 & 3.1175 \\
\hline \multirow[t]{2}{*}{2859} & 10807 & -- & - & 30.5 & 3.2767 \\
\hline & 11500 & -- & - & 29.1 & 3.4355 \\
\hline 3063 & 11500 & - & - & 29.1 & 3.4355 \\
\hline \multirow[t]{2}{*}{2142} & 12076 & - & - & 28.0 & 3.5658 \\
\hline & 20077 & $\overline{-}$ & $\therefore$ & 19.0 & 5.2520 \\
\hline 2072 & 20250 & - & - & 18.9 & 5.2865 \\
\hline 2504 & 37113 & - & - & 11.9 & 8.3863 \\
\hline
\end{tabular}


Table 9-14. Effluents $\geq L C_{50}$ at $50 \mathrm{ft}$ from discharges, and ratios of their concentrations to their respective $L_{50}$ values for each species.

\begin{tabular}{|c|c|c|c|}
\hline Platform & $\begin{array}{c}\text { Discharge } \\
\text { (bbl/d) }\end{array}$ & \multicolumn{2}{|c|}{ Ratio of Effluent Concentration to LC50 } \\
\hline & & $\begin{array}{c}\text { Mysidopsis } \\
\text { bahia }^{2}\end{array}$ & $\begin{array}{c}\text { Cyprinodon } \\
\text { variegatus }^{3}\end{array}$ \\
\hline 2816 & 140 & 3.4 & \\
\hline 2084 & 802 & 4.4 & 1.8 \\
\hline 2084 & 2,484 & 5.2 & 1.6 \\
\hline 2825 & 2,910 & 1.0 & 1.2 \\
\hline 2898 & 3,000 & & \\
\hline
\end{tabular}

1 Percent effluent

${ }^{2} L C_{50}$ results available for 41 discharges.

${ }^{3} \mathrm{LC}_{50}$ results available for 39 effluents

Table 9-15. Effluents $\geq L C_{50}$ at $200 \mathrm{ft}$ from discharges, and ratios of their concentrations ${ }^{1}$ to their respective $L_{50}$ values for each species.

\begin{tabular}{|c|c|c|c|}
\hline Platform & $\begin{array}{c}\text { Discharge } \\
\text { (bbl/d) }\end{array}$ & \multicolumn{2}{|c|}{ Ratio of Effluent Concentration to LC so } \\
\hline & & $\begin{array}{c}\text { Mysidposis } \\
\text { bahia }^{2}\end{array}$ & $\begin{array}{c}\text { Cyprinodon } \\
\text { variegatus }\end{array}$ \\
\hline 2816 & 140 & 1.0 & \\
\hline 2084 & 802 & 1.7 & \\
\hline 2084 & 2,484 & 2.2 & \\
\hline 1901 & 10,123 & 1.0 & \\
\hline 2859 & 10,807 & 1.0 & 2.2 \\
\hline 2072 & 20,250 & & \\
\hline 2504 & 37113 & 2.0 & \\
\hline
\end{tabular}

1 Percent effluent

Percent effluent

${ }^{2} L C_{50}$ results available for 41 discharges.

${ }^{3} \mathrm{LC}_{50}$ results available for 39 effluents

Chronic toxicity ratios were calculated for the estimated percent effluent at $200 \mathrm{ft}$ and the available corresponding chronic NOEL values for survival and growth inhibition. Ratios greater than one suggest a potential for toxic effects. Results of these ratio tests are shown in Tables 9-16 and 9-17.

At $200 \mathrm{ft}, 37 \%$ of the modeled effluent concentrations exceed their respective survival NOEL values for $M$. bahia, and $19 \%$ exceed their respective survival NOEL value for $C$. variegatus (Table 9-16). At $200 \mathrm{ft}, 39 \%$ of the modeled effluent concentrations exceeded their respective growth-inhibition NOEL values for $M$. bahia, and $18 \%$ exceeded their respective growth-inhibition NOEL values for $C$. variegatus (Table 9-17). Approximately two times more of the predicted 
effluent concentrations exceeded chronic NOEL values (both survival and growth-inhibition) for $M$. bahia than for $C$. variegatus.

The results suggest a potential for chronic effects within 200 feet of some discharges. All the AHQs and CHQs were determined to be lognormal distributions, as exemplified by the linearity of the plot in Figure 9-2.

Table 9-16. Survival ratios greater than one (percent effluent at 200 feet/ percent effluent NOEL).

\begin{tabular}{|c|c|c|c|}
\hline \multirow[t]{2}{*}{ Platform } & \multirow[t]{2}{*}{$\begin{array}{l}\text { Discharge } \\
\text { (bbl/d) }\end{array}$} & \multicolumn{2}{|c|}{$\begin{array}{c}\text { Survival Ratio: } \\
\text { percent effluent/NOEL }\end{array}$} \\
\hline & & $\begin{array}{c}\text { Mysidopsis } \\
\text { bahia }\end{array}$ & $\begin{array}{l}\text { Cyprinodon } \\
\text { variegatus }\end{array}$ \\
\hline 2816 & 140 & 5.8 & 1.5 \\
\hline 2816 & 614 & 6.7 & - \\
\hline 2084 & 701 & - & 1.0 \\
\hline 2084 & 802 & 6.4 & - \\
\hline 2084 & 1,201 & -- & 1.4 \\
\hline 2084 & 2,065 & 1.0 & - \\
\hline 2084 & 2,484 & 12.6 & - \\
\hline 2881 & 2,485 & 3.2 & - \\
\hline 2825 & 2,910 & 1.7 & -- \\
\hline 2898 & 3,000 & 6.7 & 2.1 \\
\hline 2084 & 3,017 & - & 1.5 \\
\hline 2084 & 3,720 & 1.7 & 1.7 \\
\hline 2523 & 5,364 & 1.1 & - \\
\hline 1901 & 10,123 & 4.9 & - \\
\hline 2859 & 10,807 & 3.3 & - \\
\hline 1901 & 11,500 & 6.9 & - \\
\hline 3063 & 11,500 & -- & 1.4 \\
\hline 2142 & 12,076 & 1.4 & -- \\
\hline 1901 & 20,077 & 5.2 & - \\
\hline 2072 & 20,250 & - & 4.8 \\
\hline 2504 & 37113 & 5.1 & -- \\
\hline
\end{tabular}

survival test results available for 43 discharges

${ }^{2}$ survival test results available for 42 effluents

These results should be taken only as an indicator of potential toxicity. The percent effluent values exceeded their respective $L C_{50}$ and NOEL values by small amounts. Controlled laboratory conditions of the toxicity tests, and the conservative CORMIX modeling constraints, do not reproduce the variable chemical and physical conditions of the open bay environment. Under natural conditions, effluent components probably vary in the water column. Therefore, it is likely that comparisons of percent effluent (at 50 or 200 feet) with percent effluent acute or chronic toxicity values yielded toxicity ratios that are overestimates. 
Table 9-17. Growth-inhibition ratios greater than one (percent effluent at 200 feet/ percent effluent NOEL).

\begin{tabular}{|c|c|c|c|}
\hline Platform & $\begin{array}{c}\text { Discharge } \\
\text { (bbl/d) }\end{array}$ & \multicolumn{2}{|c|}{$\begin{array}{c}\text { Growth Inhibition Ratio: } \\
\text { percent effluent/NOEL }\end{array}$} \\
\hline 2816 & & $\begin{array}{c}\text { Mysidopsis } \\
\text { bahia }\end{array}$ & $\begin{array}{c}\text { Cyprinodon } \\
\text { variegatus }\end{array}$ \\
\hline 2816 & 140 & 3.3 & 1.5 \\
\hline 2084 & 614 & 3.5 & -- \\
\hline 2881 & 802 & 6.4 & -- \\
\hline 2084 & 1,103 & 1.6 & -- \\
\hline 2898 & 2,484 & 1.6 & 2.1 \\
\hline 2084 & 3,000 & 6.7 & 1.5 \\
\hline 2084 & 3,017 & 1.5 & 1.7 \\
\hline 2523 & 3,720 & 3.4 & -- \\
\hline 2860 & 5,364 & 1.1 & -- \\
\hline 1901 & 6,800 & 1.2 & - \\
\hline 2859 & 10,123 & 4.9 & - \\
\hline 1901 & 10,807 & 3.3 & 1.4 \\
\hline 3063 & 11,500 & 6.9 & -- \\
\hline 2142 & 11,500 & - & 4.8 \\
\hline 1901 & 12,076 & 1.4 & -- \\
\hline 2072 & 20,077 & 10.5 & - \\
\hline 2504 & 20,250 & 1.3 & - \\
\hline
\end{tabular}

survival test results available for 41 discharges

${ }^{2}$ survival test results available for 39 effluents

Since the percent effluent values compared to the NOEL in this analysis represent the concentrations at the midline of the plume at $200 \mathrm{ft}$ from the discharges, an organism would have to live totally in the plume, within $200 \mathrm{ft}$ of the discharges for at least the period of the chronic test to be affected. This is unlikely because the plume is a relatively small fraction of the volume of water within $200 \mathrm{ft}$ of a platform. That volume, in turn, is a small fraction of the body of water in which the discharge occurs. Therefore, major effects to local populations or to the ecology of the region around open bay discharges is not expected.

The estimates of toxicity to biota are highly uncertain because of the previously described variability in natural conditions versus the controlled conditions of laboratory tests. It is also difficult to sort out the uncertainty associated with the estimation of individual effluent concentrations because of the limitations of the conservative CORMIX model (section 5-3).

Sensitivity analyses were done to see the effects of lowering all effluent concentrations at 50 and $200 \mathrm{ft}$ by $20 \%$ (Table 9-18). Further discrimination of the sensitivity of the CORMIX model was attempted by investigating predicted toxicity ratios for effluent discharge rates $(\geq 5000 \mathrm{bbl} / \mathrm{d}$ ) that best fit the derived models (Table 9-18). 
Figure 9-2. Logarithmic distribution of ratios between $\%$ effluent concentrations and the LOEL \% effluent concentrations for inhibition of growth in Mysidopsis bahia in produced waters from Louisiana open bay platforms.

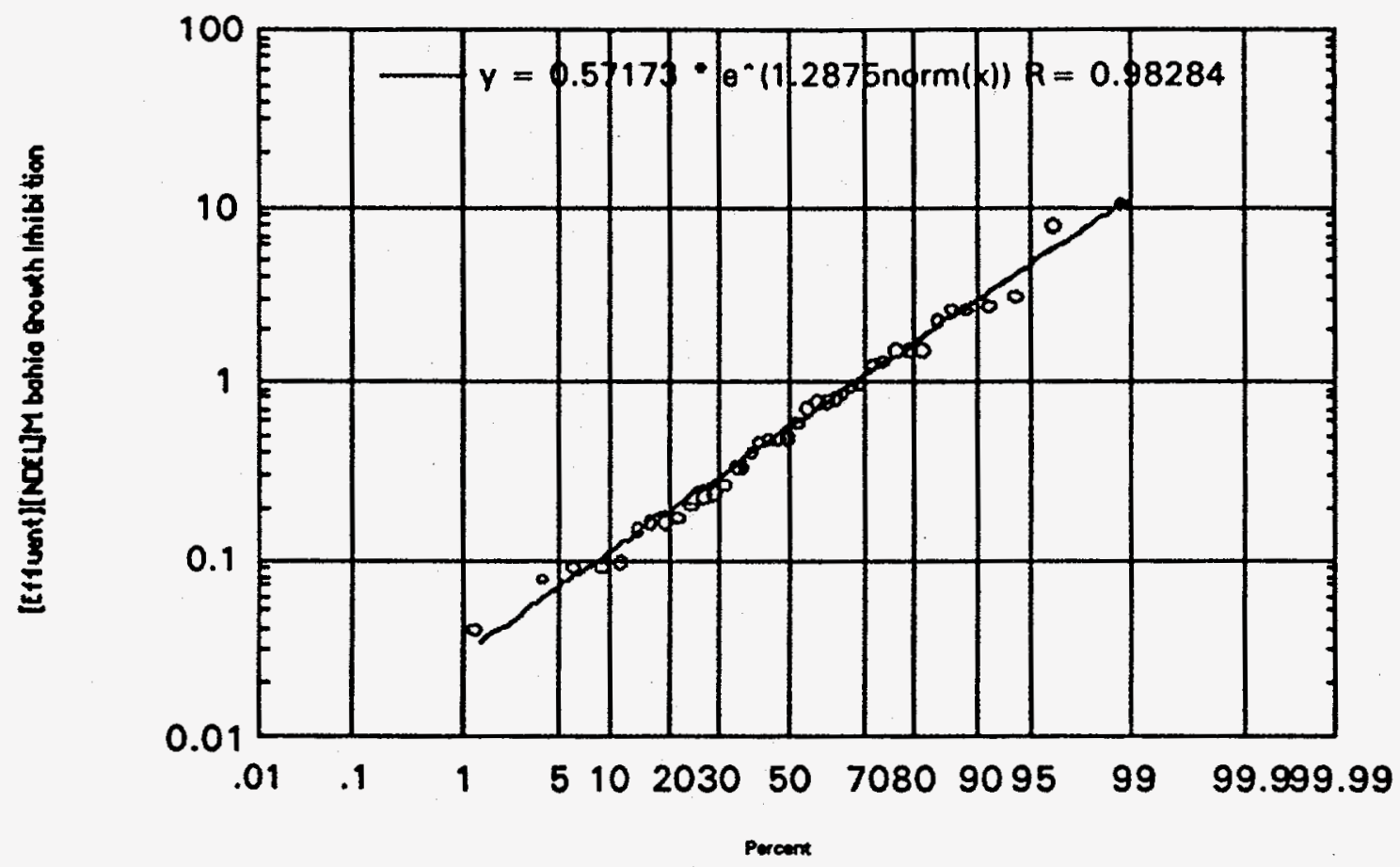


Table 9-18. Sensitivity of results to 20 percent reductions of all effluent concentrations, or when discharges equal or exceed $5000 \mathrm{bbl} / \mathrm{d}$. Values are percentage of effluent concentration values that equal or exceed respective toxicity assay results.

\begin{tabular}{|c|c|c|c|}
\hline Organism \& Analysis & LC 50 (50 ft) & Survival (200 ft) & $\begin{array}{c}\text { Growth Inhibition } \\
(\mathbf{2 0 0} \mathbf{f t})\end{array}$ \\
\hline & & & \\
\hline Mysidopsis bahia & & & 38 \\
\hline 1 & 22 & 42 & 33 \\
\hline 2 & 17 & 35 & 58 \\
\hline 3 & 27 & 65 & 50 \\
\hline 4 & 23 & 54 & \\
\hline & & & 15 \\
\hline Cyprinodon variegatus & & & 13 \\
\hline 1 & 5 & 15 & 22 \\
\hline 2 & 3 & 7 & 17 \\
\hline 3 & 9 & 21 & \\
\hline 4 & 5 & 8 & \\
\hline
\end{tabular}

1. All [Effluent].

2. All [Effluent $x$ 0.8]

3. [Effluent] $\geq 5000 \mathrm{bbl} / \mathrm{d}$

4. [Effluent $\times 0.8] \geq 5000 \mathrm{bbl} / \mathrm{d}$

Twenty percent reductions in effluent concentrations produced varying reductions in all toxicity parameters (Table 9-18: 1 versus 2; 3 versus 4). For $M$. bahia and $C$. variegatus, the percentages of discharges that might cause acute toxicity $\left(L C_{50}\right)$ at $50 \mathrm{ft}$, and chronic toxicity effects (reduced survival, and growth inhibition) at $200 \mathrm{ft}$ appear to increase by less than half when low discharge rates are excluded.

Although the effluent concentration estimates may be uncertain, the findings of potential toxicity up to $200 \mathrm{ft}$ from the discharges agree with field observations of reduced numbers of benthic species and individual animals within $100 \mathrm{~m}$ of discharges in open bays off the coast of Louisiana (Mulino et al., 1995)

Regression methods were used to look for linear, exponential, logarithmic or power relationships for the following sets of data:

- between estimated concentrations at 50 and $200 \mathrm{ft}$ from each discharge and the respective LD50 values (acute toxicity) for each discharge;

- between LD50 values (acute) and their respective NOEL values (chronic);

- between NOEL values for survival and NOEL values for growth inhibition;

- between estimated effluent concentrations at 50 and $200 \mathrm{ft}$ and their respective acute and chronic ratios;

- between acute and chronic ratios at 50 and $200 \mathrm{ft}$

- relationships between data for M. bahia and data for $C$. variegatus. 
No significant relationships $(R \geq .75)$ were detected, except between NOEL values for survival and NOEL values for growth inhibition, as demonstrated in Figure 9-3. The absence of relationships may arise from several sources:

- over-estimates of effluent concentrations for low discharge rates, as described above;

- qualitative and quantitative variability in the toxic components of the effluents;

- interspecific and intraspecific differences in response to toxicity of the effluents.

\subsection{Discussion}

Results of the analyses of toxicology testing, and the results of the analyses of individual components of produced waters, suggest that individual component analyses are not enough to explain the toxicity of produced water effluents in the water column. These analyses, the screening study of sediment components, and the field observations on benthic animals indicate that there is a potential for detrimental effects on open bay biota within LDEQ's chronic mixing zone (200 feet from the discharge). Permanent damage to regional populations of organism and ecosystems are not expected, because mixing zones represent relatively small volumes, in bodies of water with greater energy than previously studied coastal waters (e.g., canals; Boesch and Rabalais, 1989; St. Pe', 1990). 
Figure 9-3. NOEL (as percent effluent) for growth inhibition as a power function of the NOEL for survival of Cyprinodon variegatus exposed to produced waters from Louisiana open bay platforms.

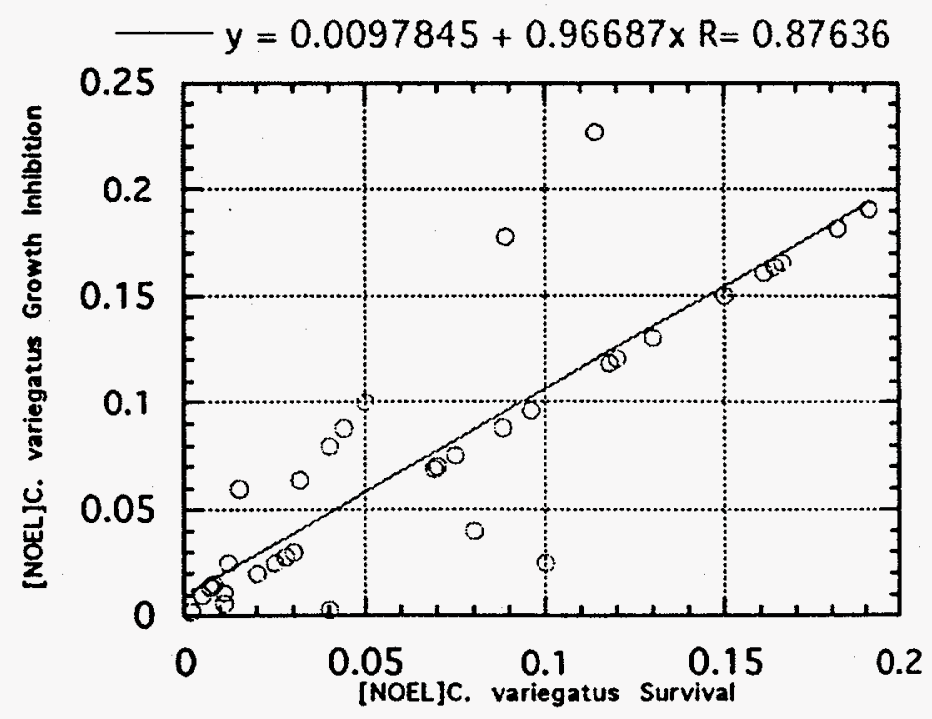




\section{SUMMARY AND CONCLUSIONS}

A tiered risk assessment approach was used for human health and ecological risks. Screening-level assessments identified potentially important contaminants and eliminated others from further consideration. Based on the results of these preliminary analyses, additional probabilistic risk assessments were done for the human health and ecological risks of contaminants that were identified as being of potential concern.

\subsection{Human Health Risk Assessment for Radium}

Screening and probabilistic human health risk assessments were done for open bay radium discharges in Louisiana. In the conservative screening analysis, estimated risks for ingestion of radium in fishes exceeded $1 \times 10^{-6}$ in all cases. These results are from a conservative, screening level assessment, and do not represent best estimates of risk associated with radium discharged by open bay platforms. They do, however, suggest the need for a more detailed, probabilistic assessment.

A probabilistic risk assessment was done using distributions of: radium concentrations in fish; rates of ingestion of fish by recreational fishermen and their families; and risk factors. Mean and median individual lifetime fatal cancer risks for both USDOE study sites (Delacroix Island and Bay de Chene; pretermination data) were less than $1 \times 10^{-5}$, and 95th percentile risks were less than $1 \times 10^{-4}$. Median individual lifetime fatal cancer risks for continuing open bay discharges were $1.4 \times 10^{-6}$, and 95th percentile risks were $2.3 \times 10^{-5}$.

These results suggest that the ingestion of radium in fish near open bay produced water platforms does not present an important risk to human health.

\subsection{Ecological Risk Assessment for Radionuclides}

In a simple screening analysis, none of the predicted doses to aquatic animals from radionuclides in produced water discharges exceeded the IAEA range associated with only potential minor effects on individual animals. Because of the conservative nature of this initial analysis, it can be concluded that no effects on aquatic animals from radionuclides discharged in produced water to open bays in Louisiana are expected.

\subsection{Human Health Risk Assessment for Chemical Contaminants}

A screening human health risk assessment was done for metals and organic compounds measured in continuing open bay discharges. This analysis followed the USEPA approach to estimating risks from toxic materials and 
carcinogens by applying RfD (reference dose) and slope factor values to estimates of chemical intake rates (USEPA, 1989). Predicted water concentrations were also compared to USEPA and Louisiana human health water quality criteria.

Arsenic, chromium, copper, silver, naphthalene, toluene and xylenes were eliminated from further consideration. Contaminants of potential concern identified in this screening step included antimony, benzene, cadmium, lead, mercury, nickel, zinc and phenol.

A more realistic and quantitative assessment was performed for contaminants identified in this screening analysis. The results show that intakes of contaminants discharged to open bays in produced water pose a negligible hazard to human health.

The potentially toxic contaminants examined (antimony, cadmium, mercury, nickel, zinc and phenol; lead was analyzed separately) all had low risks of toxic effects. The only contaminant that marginally exceeded its oral RfD value was cadmium.

Because of the concern for lead exposure to children, and the current belief that the dose-response function for lead exposure does not have a threshold, lead was analyzed in a separate probabilistic risk assessment. Risk from ingestion of lead in fish caught near platforms only slightly exceeded risks from background intake of lead and was similar to risks from ingestion of lead in fish caught in the Gulf of Mexico but not near platforms.

For benzene, the predicted distribution of values for incremental individual lifetime risk of carcinogenic mortality had a mean value of $1.6 \times 10^{-6}$ and a 95th percentile value of $7.4 \times 10^{6}$. This is within the range considered acceptable by USEPA (1 $\times 10^{-6}$ to $1 \times 10^{-4}$; Federal Register, 1991).

\subsection{Ecological Risk Assessment for Chemical Contaminants and Total Effluent}

Three ecological risk assessments were performed: a screening assessment of chemical toxicity to benthic biota; an assessment of potential toxicity of individual produced water components to fish and crustaceans in the water column; and an assessment of whole effluent toxicity to fish and crustaceans.

Screening Assessment Of Sediment Toxicity

Sediment metal and PAH concentrations measured at USDOE study sites (data collected before termination of discharges) were compared to proposed 
sediment quality criteria (ERM: Effects Range Median; ERL: Effects Range Low; Long et al., 1995).

None of the measured concentrations of metals in sediment samples exceeded their respective ERM values. In general, measured sediment concentrations were below the ERL, with the exception of arsenic and nickel. Each of these metals exceeded its ERL value in samples from at least one reference site, and each discharge site. There was no clear pattern of concentration with distance from a discharge.

With the exception of acenaphthene, individual and total PAH concentrations exceeded ERL criteria at, and $100 \mathrm{~m}$ from the discharge at Delacroix Island. Acenaphthene concentrations exceeded the ERL values at the discharge, 100, 300 and $500 \mathrm{~m}$ sample sites. Neither individual nor total PAH concentrations in sediment samples from Delacroix Island exceeded ERM criteria.

Individual and total PAH concentrations exceeded ERL criteria at the discharge site, and $100 \mathrm{~m}$ and $300 \mathrm{~m}$ from the discharge at Bay de Chene. Individual and total PAH concentrations in samples from the discharge site exceeded ERM criteria.

In preliminary results of the benthos sampling performed at the USDOE study sites Mulino et al $(1995 ; 1996)$ depressed numbers of individuals and numbers of species were found only at distances less than $100 \mathrm{~m}$ from the discharges. Although comparisons of PAH concentrations to criteria were generally consistent with the results of benthos observations, they could not explain differences between the benthic biota at the two study sites. Mulino et al., (1996) attributed the more severe impacts at Delacroix Island (smaller discharge) to hydrologic influences on salinity and oxygen content of the water.

These results are preliminary, and cannot be applied to all other open bay discharge sites with much confidence, but the discharge rates and depths of the Bay de Chene and Delacroix Island study sites are comparable (discharge rates are on high end of distribution) to those that are continuing to discharge.

\section{Assessment Of Potential Toxicity Of Individual Contaminants In The Water} Column

Worst-case predicted water column concentrations of contaminants measured in continuing open bay effluents (LDEQ permit files) were compared to USEPA and Louisiana water quality criteria.

Worst-case predicted water concentrations exceeded acute water quality standards for copper, lead, nickel, silver and zinc. Chronic water quality criteria were exceeded for antimony, cadmium, copper, lead, mercury, nickel, silver, zinc 
and phenol. Contaminants eliminated from further consideration included arsenic, chromium, benzene, naphthalene and toluene.

For contaminants not eliminated by the initial screening assessment, a quantitative risk assessment was done. Distributions of predicted chemical concentrations were compared to acute and chronic toxicity criteria for marine biota.

None of the predicted chemical concentrations ( $200 \mathrm{ft}$ ) exceeded their respective acute toxicity criteria. Antimony, phenol, and zinc concentrations did not exceed any of their respective chronic toxicity criteria. Less than five percent of the concentrations of cadmium, copper, lead, nickel and silver, at $200 \mathrm{ft}$, are expected to result in chronic toxicity to biota. More than $90 \%$ of the predicted concentrations of mercury are expected to be below its chronic toxicity criterion. Since these all represent midline values for the plumes, the expectation would be that environmental impacts of the individual chemicals would be limited.

\section{Assessment Of Effluent Toxicity}

Standard laboratory test organisms, an amphipod (Mysidopsis bahia) and the sheepshead minnow (Cyprinodon variegatus), were used in toxicity tests that were reported in LDEQ permits. Predicted water column concentrations of effluents were compared with reported results of acute and chronic toxicity tests on diluted effluent samples. For the results of each type of toxicity test, data were expressed in the same way as the predicted water column concentrations: as percent effluent.

For discharges reported to the LDEQ, modeled relationships between discharge (flow) rates and dilution factors were used to estimate concentrations of effluents at $50 \mathrm{~m}$ and $200 \mathrm{~m}$ from discharges.

Acute toxicity ratios (AHQ) were calculated between the estimated percent effluent at $50 \mathrm{ft}$ and $200 \mathrm{ft}$ from the discharge and the available corresponding $L_{50}$ values ( $M$. bahia; $C$. variegatus) for each platform). Ratios of one or greater indicate potential lethality to each species.

At $50 \mathrm{ft}, 15 \%$ of the modeled effluent concentrations exceeded their respective $L C_{50}$ values for $M$. bahia, and $5 \%$ exceeded their respective $L C_{50}$ values for $C$. variegatus. At $200 \mathrm{ft}, 15 \%$ of the modeled effluent concentrations exceeded their respective $L C_{50}$ value for $M$. bahia and $2.5 \%$ exceeded their respective $L C_{50}$ value for $C$. variegatus. The results suggest a potential for lethal effects for some discharges at 50 and at 200 feet. 
Chronic toxicity ratios were calculated for the estimated percent effluent at $200 \mathrm{ft}$ and the available corresponding chronic NOEL values for survival and growth inhibition. Ratios greater than one suggest a potential for toxic effects.

At $200 \mathrm{ft}, 37 \%$ of the modeled effluent concentrations exceed their respective survival NOEL values for $M$. bahia, and $19 \%$ exceed their respective survival NOEL value for $C$. variegatus. At $200 \mathrm{ft}, 39 \%$ of the modeled effluent concentrations exceeded their respective growth-inhibition NOEL values for $M$. bahia, and $18 \%$ exceeded their respective growth-inhibition NOEL values for $C$. variegatus. Approximately two times more of the predicted effluent concentrations exceeded chronic NOEL values (both survival and growthinhibition) for $M$. bahia than for $C$. variegatus.

The results suggest a potential for chronic effects within 200 feet of some discharges. These results should be taken only as an indicator of potential toxicity. The percent effluent values exceeded their respective NOEL values by small amounts.

Since the percent effluent values compared to the NOEL in this analysis represent the concentrations at the midline of the plume at $200 \mathrm{ft}$ from the discharges, an organism would have to live totally in the plume, within $200 \mathrm{ft}$ of the discharges for at least the period of the chronic test to be affected. This is unlikely because the plume is a relatively small fraction of the volume of water within $200 \mathrm{ft}$ of a platform. That volume, in turn, is a small fraction of the body of water in which the discharge occurs. Therefore, major effects to local populations or to the ecology of the region around open bay discharges is not expected.

\subsection{Conclusions}

The tiered approach to risk assessment is a cost-effective way to provide information needed to make risk management decisions. This screening assessment for human health and ecological risks from open bay produced water discharges in Louisiana eliminated a number of contaminants from further consideration. More quantitative assessments were performed on contaminants of potential concern.

Human health risks from radium in produced water appear to be small. Ecological risks from radium and other radionuclides in produced water also appear to be small.

Intakes of chemical contaminants in fish caught near open bay produced water discharges are expected to posed a negligible toxic hazard or carcinogenic risk to people. 
Potential impacts to benthic biota and fish and crustaceans in the water column are possible for some discharges within the $200 \mathrm{ft}$ mixing zone. Permanent damage to populations of organisms and ecosystems are not expected, because mixing zones represent relatively small volumes and animals are not expected to remain continuously in the plume. 


\section{REFERENCES}

Anderson, S.L., and F.L. Harrison, 1986, Effects of Radiation on Aquatic Organisms and Radiobiological Methodologies for Effects Assessment, USEPA Report No. 520/1-85-016, United States Environmental Protection Agency, Washington, D.C.

Armstrong, H.W., K. Fucik, J.W. Anderson and J.M. Neff, 1977, Effects of Oilfield Brine Effluent on Benthic Organisms in Trinity Bay, Texas. American Petroleum Institute, Washington D.C.

Avanti Corporation, 1993. Ocean Discharge Criteria Evaluation For The NPDES General Permit For the Western Gulf of Mexico OCS. prepared for the United States Environmental Protection Agency, Region VI, Dallas, Texas, prepared by Avanti Corporation Vienna, Virginia.

Boesh, D.F. and N.M. Rabalais, 1989, Produced Waters in Sensitive Coastal Habitats, An Analysis of Impacts: Central Coastal Gulf of Mexico, OCS Report/MMS 89-0031, United States Department of the Interior, Minerals Management Service, Gulf of Mexico OCS Regional Office, New Orleans, Louisiana.

Bouchard, D.C., R.B. Ambrose, Jr., T.O. Barnwell, Jr., and D.W. Disney, 1995, "Environmental Modeling Software at the U.S. Environmental Protection Agency's Center for Exposure Assessment Modeling", in: G.E.G. Beroggi and W.A. Wallace (eds.), Computer Supported Risk Management, pp 321360, Kluwer Academic Publishers, Dordrecht, The Netherlands.

Burmaster, D.E., K.M. Thompson, E.A.C. Crouch, C.A. Menzie and T.E. McKone, 1990, "Monte Carlo Techniques for Quantitative Uncertainty Analysis in Public Health Risk Assessment", in: SUPERFUND '90, Proceedings of the 11th National Conference, November 26-28, 1990.

Carlisle, J.C., and M.J. Wade, 1992, "Predicting Blood Lead Concentrations From Environmental Concentrations", Regulatory Toxicology and Pharmacology 16: 280-289.

Chapman, P.M., 1995a, "Extrapolating Laboratory Toxicity Results to the Field", Environ. Toxicol. Chem. 14:927-930.

Chapman, P.M., 1995a, "Do Sediment Toxicity Tests Require Field Validation", Environ. Toxicol. Chem. 14:1451-1453. 
Derosa, C.T., H. Choudhury, and W.B. Peirano, 1991. "An Integrated Exposure/pharmacokinetic Based Approach to the Assessment of Complex Mixtures, Lead: a Case Study". Toxicology and Industrial Health, Vol. 7. No. 4: 231-248.

Doneker, R.L., and G. H. Jirka, 1990, Expert System for Hydrodynamic Mixing Zone Analysis of Conventional and Toxic Submerged Single Port Discharges (CORMIX 1) EPA.600/3-90/012, United States Environmental Protection Agency, Athens, Ga.

E.V.S. Consultants, 1990, Sediment Toxicity Evaluation, API Publication 4501, American Petroleum Institute, Washington, D.C.

Federal Register, 1991, Environmental Protection Agency, National Primary Drinking Water Regulations; Radionuclides, 40 CFR Parts 141,142, 56:138:33050.

Gallaway. B.J., 1981, An Ecosystem Analysis of Oil and Gas Development on the Texas-Louisiana Continental Shelf. U.S. Fish and Wildlife Service, Office of Biological Services, Washington, D.C., FWS/OBS-81/27.

HEAST, 1991, Health Effects Assessment Summary Tables, Annual FY-1991, United States Environmental Protection Agency, OER 9200.6-303 (91-1).

IAEA, 1982. Generic Models and Parameters for Assessing the Environmental Transfer of Radionuclides from Routine Releases: Exposures of Critical Groups. Safety Series No. 57, International Atomic Energy Agency, Vienna.

IAEA, 1985, Sediment Kds and Concentration Factors for Radionuclides in the Marine Environment, Technical Report Series No. 247, International Atomic Energy Agency, Vienna.

IAEA, 1988, Assessing the Impact of Deep Sea Disposal of Low Level Radioactive Waste on Living Marine Resources, Technical Reports Series No. 288, International Atomic Energy Agency, Vienna.

ICRP, 1977, Recommendations of the International Commission on Radiological Protection, International Commission on Radiological Protection, ICRP Publication 26, Pergamon Press, Oxford.

ICRP, 1979, Limits on Intake of Radionuclides by Workers, International Commission on Radiological Protection, ICRP Publication 30, Part 1, Vol 2, Pergamon Press, Oxford. 
ICRP, 1991, "1990 Recommendations of the International Commission on Radiological Protection", Publication 60, Annals of the ICRP, 21:1-3, Pergamon Press, Oxford.

Layton, D.W, B.J. Mallon, D.H. Rosenblatt and M.J. Small, 1987, "Deriving Allowable Daily Intakes for Systemic Toxicants Lacking Chronic Toxicity Data", Regulat. Toxicol. Pharmacol. 7:96-112.

Lipfert, F., P. Moskowitz, V. Fthenakis, M. DePhillips, J. Viren and L. Saroff, 1993, An Assessment of Adult Risks of Paresthesia Due To Mercury From Coal Combustion, Biomedical and Environmental Assessment Group, BNL49862, Brookhaven National Laboratory, Upton, New York.

Lipfert, F., P. Moskowitz, V. M. Fthenakis, M. P. DePhillips, J. Viren and L. Saroff, 1994, Assessments of Mercury Health Risks To Adults From Coal Combustion, Biomedical and Environmental Assessment Group, Brookhaven National Laboratory, Upton, New York.

Long, E. R., D. D. Macdonald, S. L. Smith, F. D. Calder, 1995, "Incidence of Adverse Biological Effects Within Ranges of Chemical Concentrations in Marine and Estuarine Sediments", Environmental Management 19:81-97.

Long, E.R., and L.G. Morgan, 1990, The Potential for Biological Effects of Sediment-sorbed Contaminants Tested in the National Status and Trends Program, NOAA Tech. Memo. NOS OMA 52, U.S. National Oceanic and Atmospheric Administration, Seattle, WA.

McKone, T.E., and Daniels, J.I., 1991; "Estimating Human Exposure Through Multiple Pathways From Air, Water and Soil", Regulat. Toxicol. Pharmacol. 13:36-61.

Meinhold, A.F., and L.D. Hamilton, 1992, "Radium Concentration Factors and Their Use in Health and Environmental Risk Assessment" ", pp. 293-302, in: Produced Water, J.P. Ray and F.R: Engelhart, eds., Plenum Press, New York.

Meinhold, A.F., S. Holtzman and L. D. Hamilton, 1995, "Human Health Risk Assessment for Radium Discharged Offshore in Produced Water", Proceedings of the SPE/EPA Exploration ad Production Environmental Conference, Houston $T X$.

Middleditch, B.S., 1984. Ecological Effects of Produced Water Discharges From Offshore Oil and Gas Production Platforms. American Petroleum Institute, Washington, D.C. 
Mulino, M.M., M.F. Rayle, J.C. Francis and M.A. Poirrier, 1995, "Delineation of Biological Impact and Recovery of Selected Produced Water Discharges in Inshore Louisiana" in: Proceedings of the SPE/EPA Exploration and Production Conference, Houston, Tx.

Mulino, M.M., M.F. Rayle, J.C. Francis and M.A. Poirrier, 1996, "Delineation of Benthic Impact and Recovery at Two Produced Water Discharge Sites in Inshore Louisiana" in: Produced Water and Environmental Aspects, Plenum Press, in Press.

NCRP, 1991, Effects of lonizing Radiation on Aquatic Organisms, NCRP Report No. 109, National Council on Radiation Protection and Measurements, Bethesda, Md.

NRC, 1983, Risk Assessment in the Federal Government: Managing the Process, National Research Council, National Academy Press, Washington, D.C.

Paustenbach, D.J., D.M. Meyer, P.J. Sheenan and V. Lau, 1991, "An Assessment and Quantitative Uncertainty Analysis of the Health Risks to Workers Exposed to Chromium-Contaminated Soils", Toxicol. Indust. Health 7:159-196.

Rabalais, N.N., B. McKee, D.J. Reed and J.C. Means, 1991, Fate and Effects of Nearshore Discharges of OCS Produced Waters, Volume II, Technical Report, OCS Study/MMS 91-0005, U.S. Department of Interior, Minerals Management Service, Gulf of Mexico OCS Regional Office, New Orleans, LA.

Rosen, J. F., 1995. "Adverse Health Effects of Lead at Low Exposure Levels: Trends in Management of Childhood Lead Poisoning". Toxicology 97:1117. [

St. Pe', 1990, An Assessment of Produced Water Impacts to Low-Energy, Brackish Water Systems in Southeast Louisiana, Louisiana Department of Environmental Quality, Water Pollution Control Division, Baton Rouge, Louisiana.

Smith, J.P., H.L. Mairs, M.G. Brandsma, R.P. Meek, and R.C. Ayers, Jr. 1993. "Field Observations of Produced Water Dilution: Comparison with Dispersion Model Predictions", report prepared for the Offshore Operators Committee, August 13, 1993. 
Steimle \& Associates, Inc., 1995, Synthesis of Seafood Catch, Distribution, And Consumption Patterns in the Gulf of Mexico Region, Draft Report prepared for the United States Department of Energy, New Orleans, La.

Stephenson, M.T., 1992. A Survey of Produced Water Studies, in: J.P. Ray and F.R. Engelhardt, eds., Produced Water Technological/Environmental Issues and Solutions. Plenum Press, New York.

Strenge, D.L. and S.R. Peterson, 1989, Chemical Data Bases for the Multimedia Environmental Pollutant Assessment System (MEPAS): Version 1, PNL7145, Pacific Northwest Laboratory, Richland, Washington.

Suter, G. W., 1993 Ecological Risk Assessment, Lewis Publishers, Boca Raton, Fla.

USEPA, 1986. Air Quality Criteria for Lead. Office of Research and Development, Office of Health and Environmental Assessment, Environmental Criteria and Assessment Office, United States Environmental Protection Agency, Research Triangle Park, N.C., EPA 600/8-83-028AF, BF, DF. EPA602/8-83/028A.

USEPA, 1989a, Risk Assessment Guidance for Superfund, Volume I, Human Health Evaluation Manual (Part A) Interim Final, Office of Emergency and Remedial Response, EPAV40/1-89/002, United States Environmental Protection Agency, Washington, D.C.

USEPA, 1989b, Assessing Human Health Risks From Chemically Contaminated Fish and Shellish: A Guidance Manual, Office of Marine and Estuarine Protection, United States Environmental Protection Agency, Washington, D.C., EPA-503/8-89-002.

USEPA, 1990, Exposure Factors Handbook, Office of Health and Environmental Assessment, United States Environmental Protection Agency, Washington, D.C., EPA600/8-89/043.

USEPA, 1991, Final Draft For the Drinking Water Criteria Document on Radium, Prepared for the Drinking Water Standards Division, Office of Ground Water and Drinking Water, Office of Water, United States Environmental Protection Agency, Washington, D.C.

USEPA, 1992, Framework for Ecological Risk Assessment, Office of Research and Development, United States Environmental Protection Agency, Washington, D.C., EPA630/R-92/001. 
USEPA, 1994. Guidance Manual for the Integrated Exposure Uptake Biokinetic Model for Lead in Children. Office of Solid Waste and Emergency

Response, United States Environmental Protection Agency, Washington, D.C., EPA540/R-93/081, PB93-963510.

USEPA, 1995a. Water Quality Benefits Analysis for the Proposed Effluent Guidelines for the Coastal Subcategory of the Oil and Gas Extraction Industry. EPA821-R-95-001, Office of Water, United States Environmental Protection Agency, Washington, D.C.

USEPA, 1995b. Data from the EMAP-Estuaries Program Level database, Louisianian Province, 1991-1992. United States Environmental Protection Agency 
APPENDIX A

USDOE OPEN BAY SITES: PRELIMINARY DATA 
Table A-1. Preliminary radium data in tissue collected at Delacroix Island and Bay De Chene.

\begin{tabular}{|c|c|c|c|c|c|c|c|}
\hline Site & Survey & Station & Organism & $\begin{array}{l}\text { Tissue } \\
\text { Type* }\end{array}$ & $\begin{array}{l}\text { Number of } \\
\text { Specimens in } \\
\text { Composite }\end{array}$ & $\begin{array}{c}{ }^{228} \mathrm{Ra}\left[L L D^{\star \star}\right] \\
(\mathrm{pC} i / g)\end{array}$ & $\begin{array}{c}{ }^{228} \mathrm{Ra} \text { [LLD] } \\
(\mathrm{pCi} / \mathrm{g})\end{array}$ \\
\hline Bay de Chene & Spring 1993 & Discharge & Croaker & Whole & $\begin{array}{l}11 \\
11 \\
11 \\
11 \\
11\end{array}$ & $\begin{array}{l}0.021[0.004] \\
0.014[0.004] \\
0.024[0.004] \\
0.008[0.004] \\
0.004[0.004]\end{array}$ & $\begin{array}{l}0.038[0.012] \\
0.094[0.013] \\
0.067[0.012] \\
0.040[0.012] \\
0.029[0.012]\end{array}$ \\
\hline Bay de Chene & Spring 1993 & Discharge & Spot & Whole & $\begin{array}{l}15 \\
15 \\
15 \\
15 \\
15\end{array}$ & $\begin{array}{l}0.034[0.007] \\
0.023[0.003] \\
0.024[0.003] \\
0.026[0.003] \\
0.019[0.003]\end{array}$ & $\begin{array}{l}0.073[0.014] \\
0.086[0.009] \\
0.018[0.007] \\
0.048[0.009] \\
0.026[0.009]\end{array}$ \\
\hline Bay de Chene & Spring 1993 & Discharge & Seatrout & Whole & $\begin{array}{l}8 \\
8 \\
8 \\
8 \\
8\end{array}$ & $\begin{array}{l}0.021[0.004] \\
0.016[0.004] \\
0.016[0.006] \\
0.004[0.003] \\
0.004[0.003]\end{array}$ & $\begin{array}{l}0.057[0.012] \\
0.159[0.011] \\
0.121[0.014] \\
0.037[0.009] \\
0.105[0.009]\end{array}$ \\
\hline Bay de Chene & Spring 1993 & Discharge & Blue Crab & Edible & $\begin{array}{l}2 \\
2 \\
2 \\
2\end{array}$ & $\begin{array}{l}0.023[0.003] \\
0.009[0.003] \\
0.020[0.003] \\
0.017[0.003]\end{array}$ & $\begin{array}{l}0.056[0.009] \\
0.058[0.009] \\
0.041[0.008] \\
0.059[0.008]\end{array}$ \\
\hline Bay de Chene & Spring 1993 & Discharge & Shrimp & Edible & $\begin{array}{l}73 \\
73 \\
73 \\
73 \\
73 \\
\end{array}$ & $\begin{array}{l}0.007[0.004] \\
0.006[0.004] \\
0.006[0.004] \\
0.007[0.004] \\
0.011[0.004]\end{array}$ & $\begin{array}{c}0.026[0.010] \\
\mathrm{BDL}^{\dagger}[0.010] \\
\mathrm{BDL}[0.010] \\
\mathrm{BDL}[0.010] \\
\mathrm{BDL}[0.016]\end{array}$ \\
\hline Bay de Chene & Spring 1993 & Reference 1 & Croaker & Whole & $\begin{array}{l}14 \\
14 \\
14 \\
14 \\
14\end{array}$ & $\begin{array}{l}0.027[0.003] \\
0.009[0.003] \\
0.011[0.003] \\
0.010[0.004] \\
0.024[0.003]\end{array}$ & $\begin{array}{r}\text { BDL [0.015] } \\
\text { BDL [0.015] } \\
\text { BDL [0.015] } \\
0.046[0.019] \\
\text { BDL [0.018] }\end{array}$ \\
\hline
\end{tabular}




\begin{tabular}{|c|c|c|c|c|c|c|c|}
\hline Site & Survey & Station & Organism & $\begin{array}{l}\text { Tissue } \\
\text { Type* }\end{array}$ & $\begin{array}{l}\text { Number of } \\
\text { Specimens in } \\
\text { Composite }\end{array}$ & $\begin{array}{c}{ }^{226} \mathrm{Ra}\left[\text { [LLD }{ }^{\star \star}\right] \\
(\mathrm{pCi} / \mathrm{g})\end{array}$ & $\begin{array}{c}{ }^{228} \mathrm{Ra} \text { [LLD] } \\
\text { (pCi/g) }\end{array}$ \\
\hline Bay de Chene & Spring 1993 & Reference 1 & Spot & Whole & $\begin{array}{l}8 \\
8 \\
8 \\
8 \\
8\end{array}$ & $\begin{array}{l}0.029[0.003] \\
0.020[0.003] \\
0.024[0.003] \\
0.022[0.003] \\
0.024[0.003]\end{array}$ & $\begin{array}{l}\mathrm{BDL}[0.018] \\
\mathrm{BDL}[0.019] \\
\mathrm{BDL}[0.018] \\
\mathrm{BDL}[0.018] \\
\mathrm{BDL}[0.019]\end{array}$ \\
\hline Bay de Chene & Spring 1993 & Reference 1 & Seatrout & Whole & 4 & $0.016[0.004]$ & $0.020[0.007]$ \\
\hline Bay de Chene & Spring 1993 & Reference 1 & Shrimp & Edible & $\begin{array}{l}28 \\
28 \\
28 \\
28\end{array}$ & $\begin{array}{l}0.027[0.004] \\
0.013[0.004] \\
0.005[0.003] \\
0.014[0.003]\end{array}$ & $\begin{array}{l}\text { BDL [0.021] } \\
\text { BDL [0.021] } \\
\text { BDL [0.018] } \\
\text { BDL [0.019] }\end{array}$ \\
\hline Bay de Chene & Spring 1993 & Reference 1 & Blue Crab & Edible & 20 & $0.012[0.003]$ & BDL $[0.019]$ \\
\hline Bay de Chene & Spring 1993 & Reference 2 & Croaker & Whole & $\begin{array}{l}13 \\
13 \\
13 \\
13 \\
13 \\
\end{array}$ & $\begin{array}{l}0.031[0.004] \\
0.032[0.004] \\
0.024[0.004] \\
0.014[0.004] \\
0.032[0.004]\end{array}$ & $\begin{array}{l}\text { BDL [0.010] } \\
\text { BDL [0.011] } \\
\text { BDL [0.011] } \\
\text { BDL [0.010] } \\
\text { BDL [0.012] }\end{array}$ \\
\hline Bay de Chene & Spring 1993 & Reference 2 & Spot & Whole & $\begin{array}{l}10 \\
10 \\
10 \\
10 \\
10 \\
\end{array}$ & $\begin{array}{r}0.021[0.004] \\
0.023[0.004] \\
0.008[0.004] \\
0.022[0.004] \\
\text { BDL }[0.004]\end{array}$ & $\begin{array}{l}\text { BDL [0.013] } \\
\text { BDL [0.012] } \\
\text { BDL [0.013] } \\
\text { BDL [0.012] } \\
0.042[0.010]\end{array}$ \\
\hline Bay de Chene & Spring 1993 & Reference 2 & Seatrout & Whole & $\begin{array}{l}9 \\
9 \\
9\end{array}$ & $\begin{array}{c}\text { BDL }[0.004] \\
0.007[0.004] \\
0.012[0.004]\end{array}$ & $\begin{array}{r}0.036[0.010] \\
0.032[0.010] \\
B D L[0.010]\end{array}$ \\
\hline Bay de Chene & Spring 1993 & Reference 2 & Shrimp & Edible & $\begin{array}{l}111 \\
111 \\
111 \\
111 \\
111\end{array}$ & $\begin{array}{l}0.021[0.003] \\
0.013[0.003] \\
0.006[0.003] \\
0.010[0.003] \\
0.010[0.004]\end{array}$ & $\begin{array}{l}\text { BDL }[0.017] \\
\text { BDL [0.018] } \\
\text { BDL [0.018] } \\
\text { BDL [0.018] } \\
0.124[0.01]\end{array}$ \\
\hline
\end{tabular}




\begin{tabular}{|c|c|c|c|c|c|c|c|}
\hline Site & Survey & Station & Organism & $\begin{array}{l}\text { Tissue } \\
\text { Type* }\end{array}$ & $\begin{array}{l}\text { Number of } \\
\text { Specimens in } \\
\text { Composite }\end{array}$ & $\begin{array}{l}{ }^{220} \mathrm{Ra}\left[L L D^{\star \star}\right] \\
(\mathrm{pCi} / \mathrm{g})\end{array}$ & $\begin{array}{l}{ }^{220} \mathrm{Ra} \text { [LLD] } \\
\text { (pCi/g) }\end{array}$ \\
\hline Bay de Chene & Spring 1993 & Reference 2 & Blue Crab & Edible & $\begin{array}{l}4 \\
4 \\
4 \\
4 \\
\end{array}$ & $\begin{array}{l}0.007[0.004] \\
0.024[0.003] \\
0.023[0.003] \\
0.024[0.003]\end{array}$ & $\begin{array}{l}\text { BDL [0.010] } \\
\text { BDL [0.018] } \\
\text { BDL [0.018] } \\
\text { BDL [0.018] }\end{array}$ \\
\hline \multirow[t]{3}{*}{ Delacroix Island } & \multirow[t]{3}{*}{ Spring 1993} & \multirow[t]{3}{*}{ Discharge } & Croaker & Edible & 16 & $0.025[0.004]$ & $0.037[0.007]$ \\
\hline & & & Spot & Edible & 8 & $0.005[0.003]$ & $0.027[0.006]$ \\
\hline & & & Blue Crab & Edible & 12 & $0.013[0.003]$ & $0.032[0.006]$ \\
\hline \multirow[t]{3}{*}{ Delacroix Island } & \multirow[t]{3}{*}{ Spring 1993} & \multirow[t]{3}{*}{ Reference 1} & Croaker & Edible & 16 & $0.005[0.004]$ & $0.112[0.007]$ \\
\hline & & & Spot & Edible & 4 & $\mathrm{BDL}[0.004]$ & $0.076[0.007]$ \\
\hline & & & Blue Crab & Edible & 19 & $0.025[0.004]$ & $0.090[0.006]$ \\
\hline \multirow[t]{3}{*}{ Delacroix Island } & \multirow[t]{3}{*}{ Spring 1993} & \multirow[t]{3}{*}{ Reference 2} & Croaker & Edible & 29 & $0.018[0.003]$ & $0.039[0.007]$ \\
\hline & & & Spot & Edible & 6 & BDL [0.003] & $0.017[0.006]$ \\
\hline & & & Blue Crab & Edible & 13 & $0.023[0.004]$ & $0.013[0.008]$ \\
\hline \multirow[t]{3}{*}{ Delacroix Island } & \multirow[t]{3}{*}{ Spring 1994} & \multirow[t]{3}{*}{ Discharge } & Croaker & Edible & 56 & $0.019[0.003]$ & $0.0159[0.007]$ \\
\hline & & & Spot & Edible & 11 & BDL [0.004] & $0.036[0.008]$ \\
\hline & & & Blue Crab & Edible & 23 & $0.007[0.004]$ & $0.046[0.008]$ \\
\hline \multirow[t]{3}{*}{ Delacroix Island } & \multirow[t]{3}{*}{ Spring 1994} & \multirow[t]{3}{*}{ Reference 1} & Croaker & Edible & 16 & $0.028[0.022]$ & $0.266[0.045]$ \\
\hline & & & Spot & Edible & 4 & $B D L[0.004]$ & $0.025[0.008]$ \\
\hline & & & Blue Crab & Edible & 22 & $0.007[0.003]$ & BDL [0.008] \\
\hline \multirow[t]{3}{*}{ Delacroix Island } & \multirow[t]{3}{*}{ Spring 1994} & \multirow[t]{3}{*}{ Reference 2} & Croaker & Edible & 14 & $0.063[0.018]$ & BDL [0.042] \\
\hline & & & Spot & Edible & 5 & BDL [0.003] & $0.107[0.008]$ \\
\hline & & & Blue Crab & Edible & 20 & $0.012[0.003]$ & $0.041[0.008]$ \\
\hline
\end{tabular}

* Whole = whole specimen analyzed; edible = edible tissue analyzed.

** $L L D=$ Lower limit of detection

$\dagger \mathrm{BDL}=$ Below detection limit 
Table A-2. Codes used to identify organic compounds in sediment.

Analyte

Naphthalene

$\mathrm{C}_{1-N a p h t h a l e n e}$

$\mathrm{C}_{2}$-Naphthalene

C3-Naphthalene

C4-Naphthalene

Acenaphthylene

Acenaphthene

Biphenyl

Fluorene

$\mathrm{C}_{1}$-Fluorene

$\mathrm{C}_{2}$-Fluorene

C3-Fluorene

Dibenzothiophene

$\mathrm{C}_{1}$-Dibenzothiophene

$\mathrm{C}_{2}$-Dibenzothiophene

C3-Dibenzothiophene

Phenanthrene

Anthracene

$\mathrm{C}_{1}$-Phenanthrene/Anthracene

$\mathrm{C}_{2}$-Phenanthrene/Anthracene

$\mathrm{C}_{3}$-Phenanthrene/Anthracene

$\mathrm{C}_{4}$-Phenanthrene/Anthracene

Fluoranthene

Pyrene

C1-Fluoranthene/Pyrene

$\mathrm{C}_{2}$-Fluoranthene/Pyrene

$\mathrm{C}_{3}$-Fluoranthenec/Pyrene

Chrysene

$\mathrm{C}_{1}$-Chrysene

$\mathrm{C}_{2}$-Chrysene

$\mathrm{C}_{3}$-Chrysene

$\mathrm{C}_{4}$-Chrysene

Benzo[a]anthracene

Benzo[b]fluoranthene

Benzo[k]fluoranthene

Benzo[a]pyrene
Code

CON

CIN

$\mathrm{C} 2 \mathrm{~N}$

$\mathrm{C} 3 \mathrm{~N}$

C4N

ACEY

ACE

BIP

COF

$\mathrm{ClF}$

C2F

C3F

COD

C1D

C2D

C3D

COP

COA

$\mathrm{C}_{1} \mathrm{P} / \mathrm{A}$

$\mathrm{C}_{2} \mathrm{P} / \mathrm{A}$

C3P/A

C4P/A

Flant

Pyr

C1F/P

$\mathrm{C}_{2 \mathrm{~F} / \mathrm{P}}$

$\mathrm{C}_{3} \mathrm{~F} / \mathrm{P}$

$\mathrm{COC}$

ClC

C2C

$\mathrm{C} 3 \mathrm{C}$

$\mathrm{C} 4 \mathrm{C}$

BAA

BBF

BKE

BAP
Analyte

Code

Benzo[e]pyrene

BEP

Perylene

Indeno[1,2,3c,d]pyrene

PER

Dibenzo[a,h]anthracene

Benzo[g,h,i]perylene

DAH

BGP 
Delacroix Island Sediment PAH

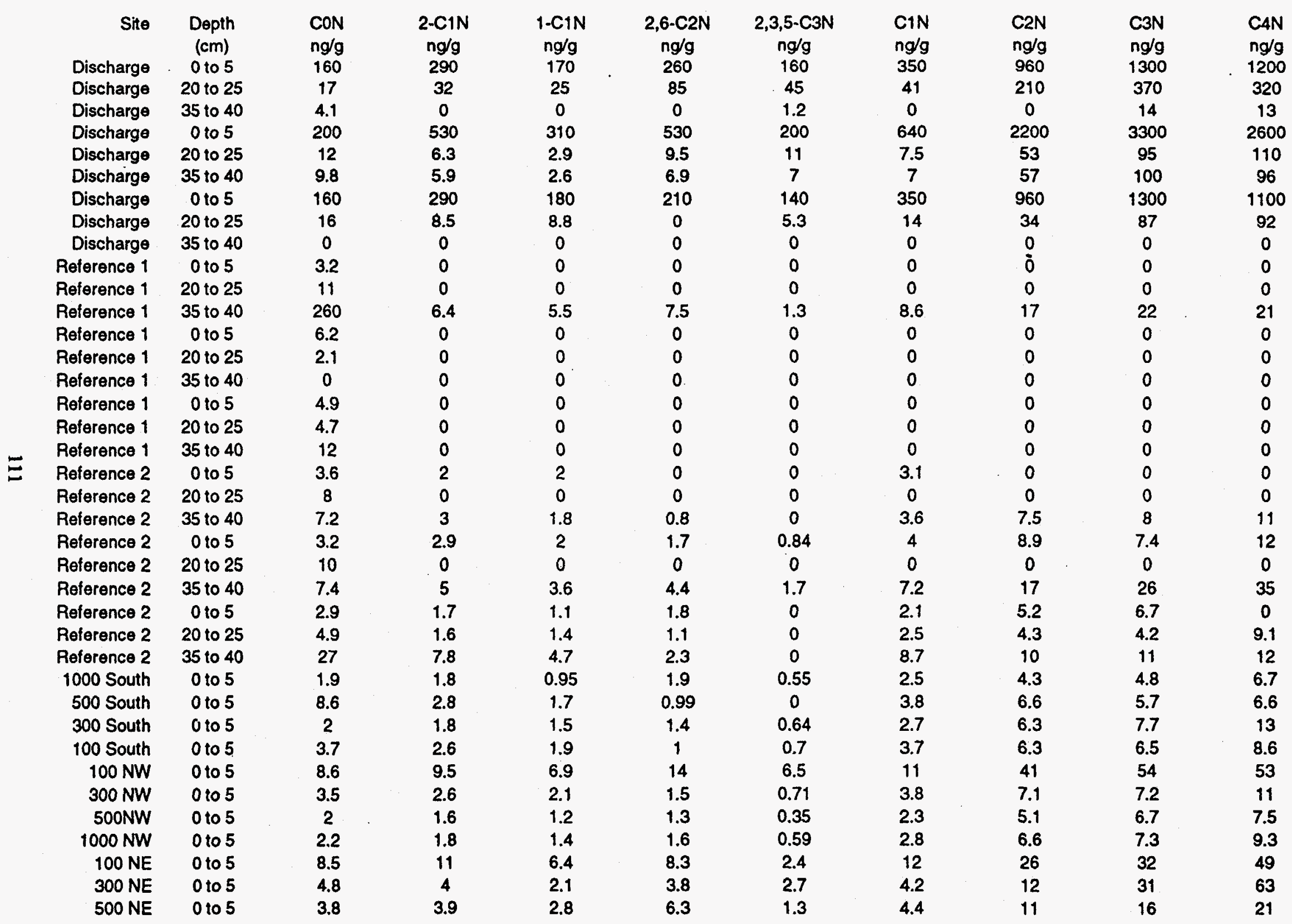

Table A-3. PAHs in sediment collected at Delacroix Island and Bay De Chene. 
Delacroix Island Sediment PAH

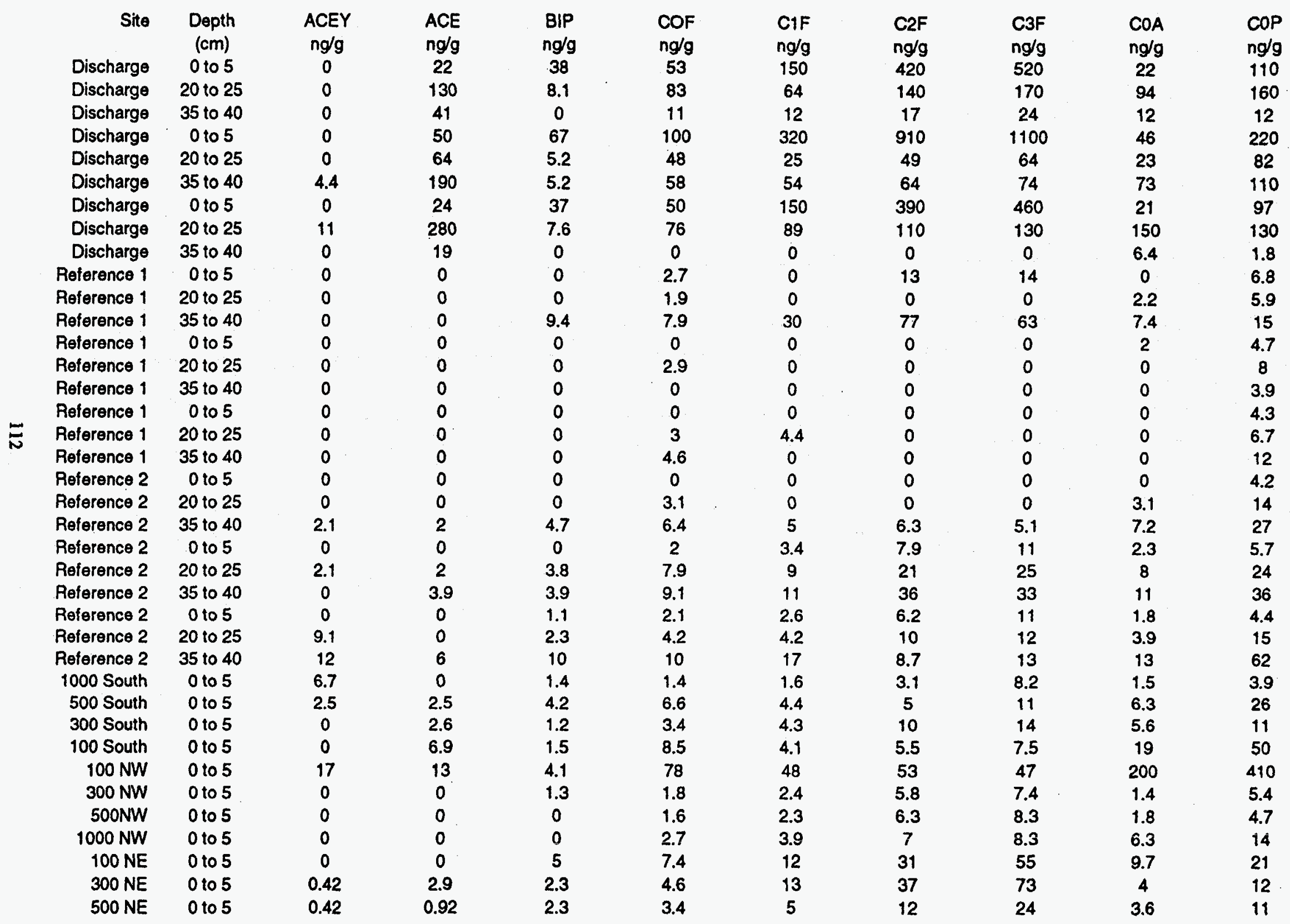


Delacroix Island Sediment PAH

\begin{tabular}{|c|c|c|c|c|c|c|c|c|c|c|}
\hline Discharge & $\begin{array}{l}\text { Depth } \\
\text { (cm) } \\
0 \text { to } 5\end{array}$ & $\begin{array}{c}1 \mathrm{C1P} \\
\mathrm{ng} / \mathrm{g} \\
88\end{array}$ & $\begin{array}{c}\text { C1P/A } \\
n g / g \\
400\end{array}$ & $\begin{array}{c}\text { C2P/A } \\
\mathrm{ng} / \mathrm{g} \\
670\end{array}$ & $\begin{array}{c}\text { C3P/A } \\
n g / g \\
470\end{array}$ & $\begin{array}{c}\text { C4P/A } \\
n g / g \\
230\end{array}$ & $\begin{array}{c}\text { FLANT } \\
\text { ng/g } \\
110\end{array}$ & $\begin{array}{c}\text { PYR } \\
n g / g \\
81\end{array}$ & $\begin{array}{c}C_{1} F / P \\
n g / g \\
120\end{array}$ & $\begin{array}{c}\text { C2F/P } \\
\text { ng/g } \\
110\end{array}$ \\
\hline Discharge & 20 to 25 & 41 & 190 & 270 & 180 & 340 & 1000 & 650 & 580 & 170 \\
\hline Discharge & 35 to 40 & 7.2 & 22 & 49 & 33 & 99 & 620 & 380 & 230 & 56 \\
\hline Discharge & 0 to 5 & 170 & 810 & 1400 & 950 & 510 & 240 & 170 & 270 & 240 \\
\hline Discharge & 20 to 25 & 18 & 69 & 96 & 68 & 68 & 270 & 170 & 110 & 38 \\
\hline Discharge & 35 to 40 & 45 & 130 & 190 & 99 & 260 & 1400 & 880 & 580 & 170 \\
\hline Discharge & 0105 & 86 & 370 & 630 & 450 & 250 & 150 & 100 & 130 & 98 \\
\hline Discharge & 20 to 25 & 72 & 260 & 340 & 190 & 690 & 3500 & 2200 & 1700 & 440 \\
\hline Discharge & 35 to 40 & 2 & 7.7 & 6.3 & 6.6 & 6 & 47 & 23 & 9.7 & 4.4 \\
\hline Reference 1 & 0 to 5 & 4.4 & 15 & 25 & 23 & 13 & 23 & 18 & 13 & 8.3 \\
\hline Reference 1 & 20 to 25 & 2 & 6.3 & 9.6 & 18 & 20 & 20 & 17 & 12 & 8 \\
\hline Reference 1 & 35 to 40 & 6.7 & 30 & 50 & 42 & 74 & 32 & 17 & 26 & 0 \\
\hline Reference 1 & 0 to 5 & 3.6 & 12 & 14 & 17 & 9.9 & 19 & 14 & 11 & 9.4 \\
\hline Reference 1 & 20 to 25 & 3.7 & 11 & 13 & 17 & 15 & 26 & 17 & 13 & 8.3 \\
\hline Reterence 1 & 35 to 40 & 0 & 0 & 0 & 0 & 0 & 5.2 & 5.1 & 0 & 0 \\
\hline Reference 1 & 0 to 5 & 2.9 & 9.8 & 15 & 21 & 17 & 19 & 14 & 9.7 & 7.7 \\
\hline Reference 1 & 20 to 25 & 3 & 7 & 5.6 & 11 & 9.8 & 23 & 16 & 12 & 6 \\
\hline Reference 1 & 35 to 40 & 5.4 & 13 & 5.8 & 0 & 0 & 24 & 18 & 13 & 0 \\
\hline Reference 2 & 0 to 5 & 1.5 & 6.9 & 12 & 16 & 12 & 13 & 9.7 & 8.3 & 6.8 \\
\hline Reference 2 & 20 to 25 & 5.1 & 12 & 16 & 16 & 14 & 45 & 33 & 24 & 13 \\
\hline Reference 2 & 35 to 40 & 4.5 & 16 & 13 & 7 & 6.1 & 62 & 46 & 32 & 8.5 \\
\hline Reference 2 & 0 to 5 & 2.4 & 9.4 & 15 & 13 & 9.6 & 25 & 20 & 12 & 7.2 \\
\hline Reference 2 & 20 to 25 & 4.3 & 21 & 20 & 12 & 14 & 69 & 57 & 33 & 11 \\
\hline Reference 2 & 35 to 40 & 8.9 & 36 & 53 & 35 & 42 & 160 & 120 & 67 & 25 \\
\hline Reference 2 & 0 to 5 & 2 & 9.2 & 14 & 12 & 7.9 & 19 & 15 & 9.2 & 6.2 \\
\hline Reference 2 & 20 to 25 & 2.9 & 10 & 14 & 8.5 & 6.2 & 42 & 34 & 21 & 6.4 \\
\hline Relerence 2 & 35 to 40 & 7.1 & 25 & 15 & 9.4 & 7.3 & 94 & 74 & 47 & 12 \\
\hline 1000 South & 0 to 5 & 1.7 & 7 & 12 & 10 & 10 & 22 & 19 & 12 & 8.8 \\
\hline 500 South & 0 to 5 & 3.4 & 13 & 8.3 & 6.1 & 6.4 & 56 & 43 & 24 & 8.9 \\
\hline 300 South & 0 to 5 & 3.5 & 15 & 22 & 17 & 25 & 64 & 50 & 38 & 24 \\
\hline 100 South & 0 to 5 & 5.5 & 22 & 18 & 11 & 27 & 110 & 88 & 51 & 18 \\
\hline $100 \mathrm{NW}$ & 0 to 5 & 50 & 250 & 150 & 70 & 190 & 900 & 570 & 460 & 130 \\
\hline $300 \mathrm{NW}$ & 0 to 5 & 2.2 & 7.3 & 11 & 7.9 & 9.7 & 15 & 12 & 12 & 7 \\
\hline $500 N W$ & 0 to 5 & 1.9 & 7.6 & 14 & 11 & 8.6 & 23 & 18 & 11 & 7.7 \\
\hline $1000 \mathrm{NW}$ & 0 to 5 & 4.5 & 19 & 19 & 11 & 17 & 53 & 35 & 31 & 13 \\
\hline $100 \mathrm{NE}$ & 0105 & 8.7 & 32 & 65 & 62 & 58 & 110 & 99 & 67 & 36 \\
\hline $300 \mathrm{NE}$ & 0 to 5 & 7.7 & 24 & 64 & 64 & 47 & 47 & 40 & 38 & 21 \\
\hline $500 \mathrm{NE}$ & 0 to 5 & 5.6 & 18 & 33 & 25 & 19 & 43 & 36 & 24 & 12 \\
\hline
\end{tabular}




\section{Delacroix Island Sediment PAH}

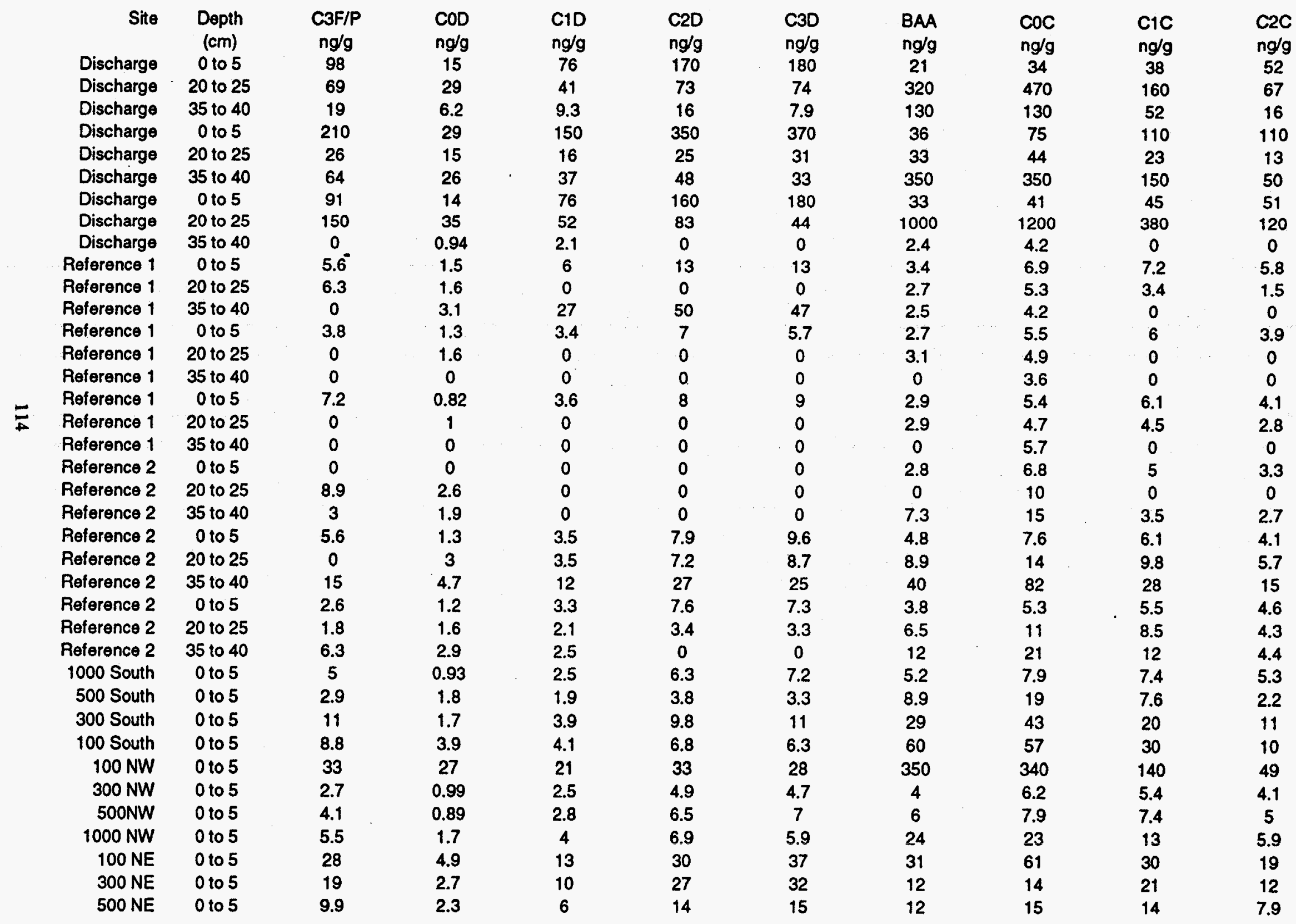


Delacroix Island Sediment PAH

\begin{tabular}{|c|c|c|c|c|c|c|c|c|c|c|}
\hline Discharge & $\begin{array}{l}\text { Dopth } \\
\text { (cm) } \\
0 \text { to } 5\end{array}$ & $\begin{array}{c}\text { C3C } \\
n g / 9 \\
58\end{array}$ & $\begin{array}{c}\mathrm{C} 4 \mathrm{C} \\
\mathrm{ng} / \mathrm{g} \\
20\end{array}$ & $\begin{array}{c}\text { BBF } \\
n g / g \\
25\end{array}$ & $\begin{array}{c}\mathrm{BKF} \\
\mathrm{ng} / \mathrm{g} \\
6\end{array}$ & $\begin{array}{c}\text { BEP } \\
\mathrm{ng} / \mathrm{g} \\
12\end{array}$ & $\begin{array}{c}\text { BAP } \\
\mathrm{ng} / \mathrm{g} \\
9\end{array}$ & $\begin{array}{l}\text { PER } \\
\mathrm{ng} / \mathrm{g} \\
110\end{array}$ & $\begin{array}{c}\text { IND } \\
n g / g \\
7.7\end{array}$ & $\begin{array}{c}\text { DAH } \\
n g / g \\
0\end{array}$ \\
\hline Discharge & 20 to 25 & 55 & 25 & 390 & 140 & 160 & 210 & 190 & 120 & 35 \\
\hline Discharge & 35 to 40 & 10 & 3.8 & 100 & 36 & 40 & 48 & 120 & 24 & 8.4 \\
\hline Discharge & 0 to 5 & 110 & 95 & 48 & 17 & 24 & 23 & 190 & 15 & 4.1 \\
\hline Discharge & 20 to 25 & 8.5 & 0 & 41 & 13 & 20 & 16 & 140 & 14 & 2.3 \\
\hline Discharge & 35 to 40 & 37 & 7.8 & 320 & 92 & 120 & 170 & 180 & 91 & 27 \\
\hline Discharge & 0105 & 55 & 24 & 32 & 9 & 15 & 13 & 100 & 9 & 0 \\
\hline Discharge & 20 to 25 & 48 & 81 & 800 & 270 & 320 & 470 & 220 & 230 & 67 \\
\hline Discharge & 35 to 40 & 0 & 0 & 4.7 & 1.2 & 1.8 & 1.3 & 110 & 1.3 & 0 \\
\hline Reference 1 & 0 to 5 & 5.4 & 0 & 11 & 2.1 & 5.4 & 2.6 & 52 & 3.5 & 0 \\
\hline Reference 1 & 20 to 25 & 0 & 0 & 7.9 & 2.4 & 3.9 & 2.7 & 55 & 3.2 & 0 \\
\hline Reference 1 & 35 to 40 & 0 & 0 & 0 & 0 & 2.2 & 0 & 75 & 2.1 & 0 \\
\hline Reference 1 & 0 to 5 & 3.2 & 0 & 8.1 & 2.1 & 4.3 & 1.6 & 54 & 3.2 & 0 \\
\hline Reference 1 & 20 to 25 & 0 & 0 & 7.3 & 2 & 3.9 & 2.5 & 89 & 3.1 & 0 \\
\hline Reference 1 & 35 to 40 & 0 & 0 & 3.3 & 0.76 & 1.9 & 0 & 140 & 0 & 0 \\
\hline Reference 1 & 0 to 5 & 0 & 0 & 8.5 & 2.4 & 4.2 & 2.7 & 52 & 2.9 & 0 \\
\hline Reference 1 & 20 to 25 & 0 & 0 & 7.2 & 2.2 & 3.7 & 2.3 & 60 & 3.4 & 0 \\
\hline Reference 1 & 35 to 40 & 0 & 0 & 5.7 & 1.7 & 2.7 & 1.2 & 130 & 0 & 0 \\
\hline Reference 2 & 0 to 5 & 0 & 0 & 6.3 & 1.9 & 3.3 & 1.7 & 41 & 2.8 & 0 \\
\hline Reference 2 & 20 to 25 & 0 & 0 & 9.2 & 2 & 4.2 & 2 & 45 & 3.2 & 0 \\
\hline Reference 2 & 35 to 40 & 0 & 0 & 15 & 3.7 & 7.9 & 3.9 & 84 & 5.3 & 0 \\
\hline Reference 2 & 0 to 5 & 1.8 & 4.4 & 12 & 2.7 & 6 & 3.3 & 63 & 4 & 0 \\
\hline Reference 2 & 20 to 25 & 0 & 0 & 18 & 4.4 & 8.6 & 4.6 & 60 & 5.7 & 1.1 \\
\hline Reference 2 & 35 to 40 & 9.8 & 5.1 & 60 & 19 & 28 & 30 & 110 & 22 & 5.1 \\
\hline Reference 2 & 0 to 5 & 2.9 & 0 & 8.4 & 2.3 & 4.1 & 2.4 & 52 & 32 & 0.65 \\
\hline Reference 2 & 20 to 25 & 0 & 0 & 15 & 3.1 & 7.9 & 4.1 & 61 & 5.2 & 1.5 \\
\hline Reference 2 & 35 to 40 & 0 & 0 & 24 & 4.7 & 11 & 5.7 & 71 & 6.1 & 0 \\
\hline 1000 South & 0 to 5 & 4.9 & 5.1 & 14 & 3.5 & 7.1 & 4.1 & 80 & 4.6 & 1 \\
\hline 500 South & 0 to 5 & 1.4 & 2.9 & 17 & 5 & 9 & 5.9 & 40 & 5.3 & 1.3 \\
\hline 300 South & 0 to 5 & 9.8 & 8.4 & 52 & 16 & 25 & 25 & 85 & 16 & 4.3 \\
\hline 100 South & 0 to 5 & 7 & 6 & 77 & 25 & 39 & 55 & 70 & 32 & 8.3 \\
\hline $100 \mathrm{NW}$ & 0 to 5 & 40 & 43 & 280 & 110 & 130 & 210 & 140 & 110 & 36 \\
\hline $300 \mathrm{NW}$ & 0 to 5 & 3.8 & 3.1 & 11 & 2.1 & 5.3 & 3 & 200 & 3.5 & 0 \\
\hline $500 N W$ & 0 to 5 & 4.4 & 4.1 & 14 & 4 & 6.7 & 4.4 & 78 & 4.5 & 1 \\
\hline $1000 \mathrm{NW}$ & 0 to 5 & 4.8 & 2.8 & 27 & 9.1 & 13 & 15 & 58 & 8.1 & 2.9 \\
\hline $100 \mathrm{NE}$ & 0 to 5 & 20 & 13 & 52 & 17 & 27 & 22 & 140 & 16 & 4.5 \\
\hline $300 \mathrm{NE}$ & 0 to 5 & 11 & 7.2 & 23 & 6.2 & 11 & 8.6 & 190 & 8.3 & 1.9 \\
\hline $500 \mathrm{NE}$ & 0 to 5 & 5.7 & 6 & 24 & 6.3 & 13 & 8.7 & 140 & 9.2 & 2 \\
\hline
\end{tabular}




\begin{tabular}{|c|c|c|c|}
\hline Site & $\begin{array}{l}\text { Depth } \\
\text { (cm) }\end{array}$ & $\begin{array}{l}\text { BGP } \\
\mathrm{ng} / \mathrm{g}\end{array}$ & $\begin{array}{c}\text { Total PAH } \\
n g / g\end{array}$ \\
\hline Discharge & 0 to 5 & 10 & 9405.7 \\
\hline Discharge & 20 to 25 & 100 & 8143.1 \\
\hline Discharge & 35 to 40 & 22 & 2456.1 \\
\hline Discharge & 0 to 5 & 16 & 20065.1 \\
\hline Discharge & 20 to 25 & 16 & 2071.2 \\
\hline Discharge & 35 to 40 & 81 & 6912.6 \\
\hline Discharge & 0 to 5 & 11 & 9142 \\
\hline Discharge & 20 to 25 & 190 & 16401.2 \\
\hline Discharge & 35 to 40 & 2.3 & 272.14 \\
\hline Reference 1 & 0 to 5 & 5 & 331.8 \\
\hline Reference 1 & 20 to 25 & 5.6 & 235.4 \\
\hline Reference 1 & 35 to 40 & 2.4 & 1052.2 \\
\hline Reference 1 & 0 to 5 & 5.4 & 244 \\
\hline Reference 1 & 20 to 25 & 4.6 & 259 \\
\hline Reference 1 & 35 to 40 & 1.8 & 165.56 \\
\hline Reference 1 & 0 to 5 & 5.9 & 251.02 \\
\hline Reference 1 & 20 to 25 & 5.6 & 212.5 \\
\hline Reference 1 & 35 to 40 & 5.7 & 260.5 \\
\hline Reference 2 & 0 to 5 & 5.4 & 181.4 \\
\hline Reference 2 & 20 to 25 & 7 & 300.4 \\
\hline Reference 2 & 35 to 40 & 6.5 & 463.5 \\
\hline Reference 2 & 0 to 5 & 5.7 & 342.24 \\
\hline Reference 2 & 20 to 25 & 8 & 525.3 \\
\hline Reference 2 & 35 to 40 & 23 & 1358.8 \\
\hline Reference 2 & 0 to 5 & 3.8 & 294.95 \\
\hline Reference 2 & 20 to 25 & 9.2 & 384.3 \\
\hline Reference 2 & 35 to 40 & 10 & 719.6 \\
\hline 1000 South & 0 to 5 & 6.3 & 334.03 \\
\hline 500 South & 0 to 5 & 7.3 & 420.89 \\
\hline 300 South & 0 to 5 & 17 & 746.54 \\
\hline 100 South & 0 to 5 & 33 & 1027.7 \\
\hline $100 \mathrm{NW}$ & 0 to 5 & 91 & 6055.6 \\
\hline $300 \mathrm{NW}$ & 0 to 5 & 5.5 & 421.9 \\
\hline $500 \mathrm{NW}$ & 0 to 5 & 5.8 & 330.34 \\
\hline $1000 \mathrm{NW}$ & 0 to 5 & 8.6 & 517.49 \\
\hline $100 \mathrm{NE}$ & 0105 & 21 & 1420.8 \\
\hline $300 \mathrm{NE}$ & 0 to 5 & 12 & 1058.42 \\
\hline $500 \mathrm{NE}$ & 0 to 5 & 12 & 671.74 \\
\hline
\end{tabular}


Bay de Chene Sediment PAH

\begin{tabular}{|c|c|c|c|c|c|c|c|c|c|c|}
\hline $\begin{array}{r}\text { Site } \\
\text { Discharge }\end{array}$ & $\begin{array}{c}\text { Depth } \\
\text { (cm) } \\
0 \text { to } 5\end{array}$ & $\begin{array}{c}\mathrm{CON} \\
\mathrm{ng} / \mathrm{g} \\
56\end{array}$ & $\begin{array}{c}2-\mathrm{C} 1 \mathrm{~N} \\
\mathrm{ng} / \mathrm{g} \\
61\end{array}$ & $\begin{array}{c}1-\mathrm{C} 1 \mathrm{~N} \\
\mathrm{ng} / \mathrm{g} \\
40\end{array}$ & $\begin{array}{c}2,6-\mathrm{C} 2 \mathrm{~N} \\
\mathrm{ng} / \mathrm{g} \\
77\end{array}$ & $\begin{array}{c}2,3,5-\mathrm{C} 3 \mathrm{~N} \\
\mathrm{ng} / \mathrm{g} \\
83\end{array}$ & $\begin{array}{c}\mathrm{C} 1 \mathrm{~N} \\
\mathrm{ng} / \mathrm{g} \\
74\end{array}$ & $\begin{array}{c}\mathrm{C} 2 \mathrm{~N} \\
\mathrm{ng} / \mathrm{g} \\
340\end{array}$ & $\begin{array}{l}\text { C3N } \\
n g / g \\
820\end{array}$ & $\begin{array}{l}\text { C4N } \\
n g / 9 \\
1000\end{array}$ \\
\hline Discharge & 20 to 25 & 46 & 82 & 47 & 75 & 52 & 92 & 360 & 980 & 1200 \\
\hline Discharge & 35 to 40 & 61 & 510 & 480 & 670 & 320 & 680 & 2600 & 3800 & 3400 \\
\hline Discharge & 0 to 5 & 110 & 110 & 68 & 320 & 320 & 130 & 1400 & 3600 & 4200 \\
\hline Discharge & 20 to 25 & 46 & 92 & 51 & 160 & 110 & 99 & 600 & 1700 & 2100 \\
\hline Discharge & 35 to 40 & 56 & 890 & 810 & 950 & 540 & 1200 & 4200 & 5500 & 4600 \\
\hline Discharge & 0 to 5 & 160 & 140 & 120 & 110 & 110 & 180 & 520 & 1100 & 1400 \\
\hline Discharge & 20 to 25 & 57 & 120 & 74 & 160 & 100 & 140 & 740 & 2000 & 2400 \\
\hline Discharge & 35 to 40 & 70 & 670 & 670 & 940 & 490 & 920 & 3800 & 5100 & 4300 \\
\hline Reference 1 & 0 to 5 & 3.5 & 0 & 0 & 0 & 0 & 0 & 0 & 0 & 0 \\
\hline Reference 1 & 20 to 25 & 6.8 & 2.6 & 1.7 & 0 & 0 & 3.1 & 8.2 & 6.3 & 0 \\
\hline Reference 1 & 35 to 40 & 2.5 & 1.5 & 0 & 0 & 0 & 1.6 & 5 & 0 & 0 \\
\hline Reference 1 & 0 to 5 & 6.6 & 2.6 & 2.2 & 0 & 0 & 4 & 7.2 & 4.4 & 5.7 \\
\hline Reference 1 & 20 to 25 & 6.4 & 3.1 & 2 & 0 & 0 & 3.8 & 7.5 & 0 & 0 \\
\hline Reference 1 & 35 to 40 & 3.1 & 0 & 0 & 0 & 0 & 0 & 0 & 0 & 0 \\
\hline Reference 1 & 0 to 5 & 2.8 & 0 & 0 & 0 & 0 & 0 & 0 & 0 & 0 \\
\hline Reference 1 & 20 to 25 & 6.7 & 2.1 & 0 & 0 & 0 & 3.5 & 8.6 & 0 & 0 \\
\hline Reference 1 & 35 to 40 & 4 & 2.6 & 1.3 & 0 & 0 & 3.2 & 0 & 0 & 0 \\
\hline Reference 2 & 0 to 5 & 5 & 4 & 0 & 2.2 & 0 & 5.1 & 9.1 & 8.1 & 10 \\
\hline Reference 2 & 20 to 25 & 4.7 & 1.9 & 0.95 & 1.4 & 1.2 & 2.9 & 4.8 & 5.3 & 5 \\
\hline Reference 2 & 35 to 40 & 3.7 & 2.1 & 1.5 & 0 & 0 & 2 & 6.1 & 6.7 & 7.2 \\
\hline Reference 2 & 0 to 5 & 3.4 & 2.8 & 1.5 & 1.2 & 0.53 & 4.4 & 9.1 & 9.9 & 12 \\
\hline Reference 2 & 20 to 25 & 3.6 & 1.4 & 1 & 0.52 & 0.54 & 1.4 & 4 & 4.2 & 3.2 \\
\hline Reference 2 & 35 to 40 & 3.8 & 1.4 & 0.97 & 0.63 & 0 & 1.7 & 4.5 & 3.2 & 3.6 \\
\hline Reference 2 & 0 to 5 & 5 & 3.4 & 1.9 & 1.04 & 0.95 & 3.5 & 8 & 7.7 & 9.6 \\
\hline Reference 2 & 201025 & 5 & 2.7 & 1.3 & 1.4 & 1.1 & 2.3 & 6.2 & 9.3 & 11 \\
\hline Reference 2 & 35 to 40 & 3.7 & 1.5 & 0.93 & 5.9 & 0.59 & 1.6 & 3.3 & 2.9 & 1.9 \\
\hline $300 \mathrm{ft} \mathrm{NE}$ & 0 to 5 & 11 & 12 & 6.6 & 5.6 & 2.9 & 12 & 23 & 25 & 34 \\
\hline $500 \mathrm{ft} \mathrm{NE}$ & 0 to 5 & 5.2 & 4.9 & 2.1 & 2.6 & 1.3 & 4.4 & 9.9 & 12 & 19 \\
\hline $1000 \mathrm{ttNE}$ & 0 to 5 & 2.7 & 2.1 & 0.96 & 0.59 & 0.45 & 1.8 & 3.9 & 4.3 & 4.6 \\
\hline $1000 \mathrm{ft} \mathrm{SE}$ & 0105 & 2.9 & 2.5 & 1.4 & 1.4 & 0.76 & 2.5 & 5.3 & 6.2 & 7.9 \\
\hline $500 \mathrm{ft} \mathrm{SE}$ & 0 to 5 & 1.6 & 1.4 & 1.2 & 0.79 & 0.59 & 1.5 & 3.9 & 4.1 & 0.53 \\
\hline $100 \mathrm{ft} \mathrm{SW}$ & 0 to 5 & 14 & 16 & 6.7 & 6.8 & 3.9 & 14 & 27 & 43 & 58 \\
\hline $300 \mathrm{ft} \mathrm{SW}$ & 0 to 5 & 3.8 & 2.6 & 1.2 & 1.3 & 0.57 & 2.4 & 6.5 & 7.4 & 9.4 \\
\hline $500 \mathrm{ft} \mathrm{SW}$ & 0 to 5 & 2.2 & 1.7 & 1.2 & 0.74 & 0.58 & 1.7 & 4.3 & 4.5 & 5.3 \\
\hline $1000 \mathrm{ft} \mathrm{SW}$ & 0 to 5 & 4.3 & 2.9 & 1.6 & 2 & 0.79 & 3.5 & 7.9 & 9.3 & 13 \\
\hline $100 \mathrm{ft} \mathrm{NW}$ & 0 to 5 & 32 & 38 & 16 & 23 & 13 & 38 & 74 & 130 & 240 \\
\hline $300 \mathrm{ft} \mathrm{NW}$ & 0 to 5 & 21 & 20 & 9.1 & 16 & 9 & 20 & 56 & 100 & 120 \\
\hline $500 \mathrm{ft} \mathrm{NW}$ & 0 to 5 & 5.8 & 5 & 2.2 & 3.3 & 1.8 & 4.9 & 11 & 16 & 25 \\
\hline $1000 \mathrm{ft} \mathrm{NW}$ & 0 to 5 & 3.6 & 3.6 & 1.9 & 2.1 & 1.4 & 4.2 & 7.9 & 11 & 16 \\
\hline $100 \mathrm{ft}$ NE & 0 to 5 & 38 & 32 & 17 & 30 & 43 & 35 & 130 & 400 & 520 \\
\hline
\end{tabular}




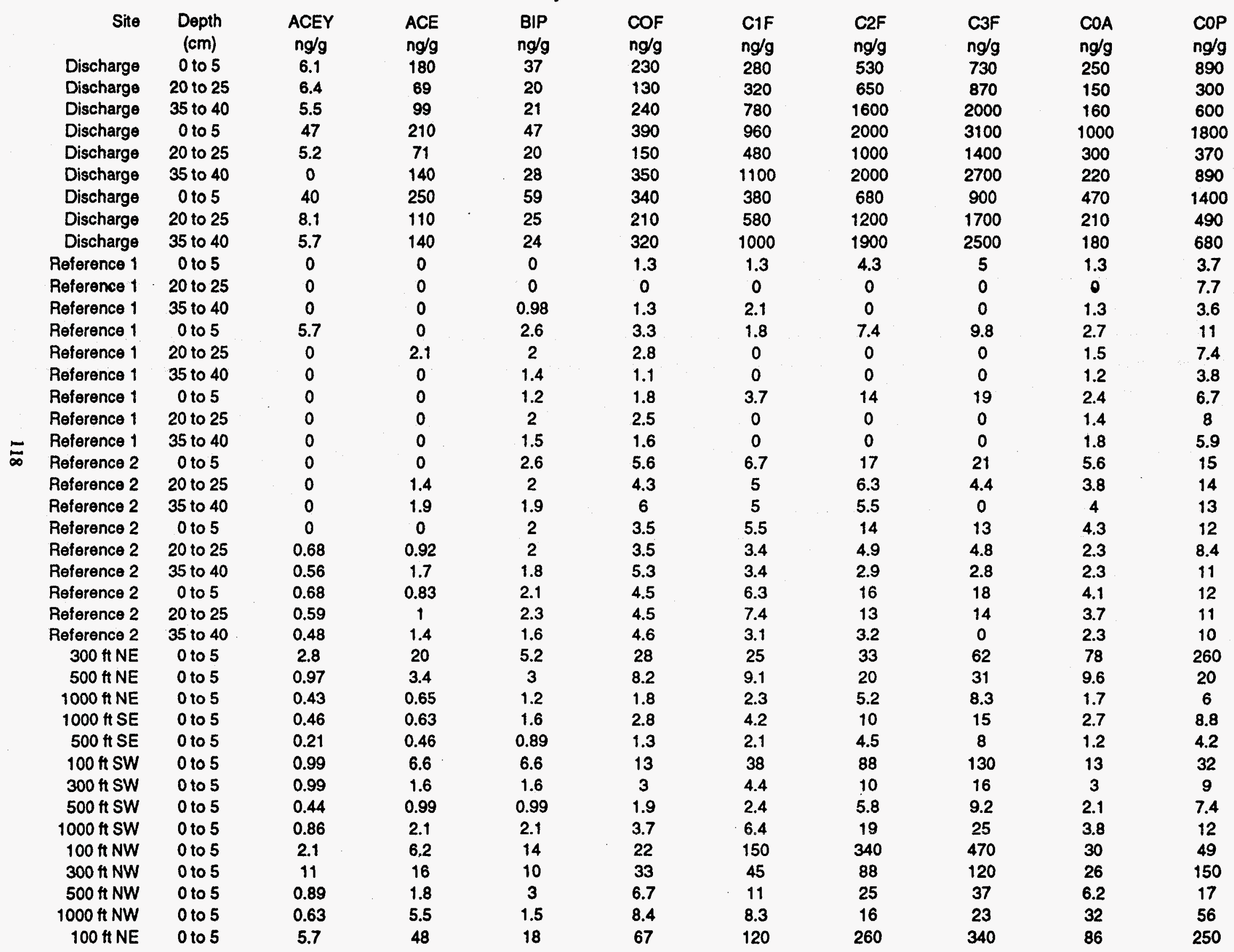




\begin{tabular}{|c|c|c|c|c|c|c|c|c|c|c|}
\hline Discharge & $\begin{array}{l}\text { Depth } \\
\text { (cm) } \\
0 \text { to } 5\end{array}$ & $\begin{array}{c}1 \mathrm{C} 1 \mathrm{P} \\
\mathrm{ng} / \mathrm{g} \\
160\end{array}$ & $\begin{array}{c}\text { C1P/A } \\
\text { ng/g } \\
570\end{array}$ & $\begin{array}{c}\text { C2P/A } \\
n g / g \\
1000\end{array}$ & $\begin{array}{c}\text { C3P/A } \\
\text { ng/g } \\
810\end{array}$ & $\begin{array}{c}\text { C4P/A } \\
n g / g \\
760\end{array}$ & $\begin{array}{c}\text { FLANT } \\
n g / 9 \\
2100\end{array}$ & $\begin{array}{l}\text { PYR } \\
n g / g \\
1500\end{array}$ & $\begin{array}{c}\text { C1F/P } \\
n g / g \\
930\end{array}$ & $\begin{array}{c}\text { C2F/P } \\
n g / g \\
480\end{array}$ \\
\hline Discharge & 20 to 25 & 140 & 460 & 1100 & 980 & 790 & 1000 & 810 & 640 & 440 \\
\hline Discharge & 35 to 40 & 410 & 1400 & 2600 & 2000 & 1300 & 780 & 650 & 670 & 650 \\
\hline Discharge & 0 to 5 & 600 & 2500 & 5100 & 3800 & 8300 & 8100 & 6100 & 11000 & 5800 \\
\hline Discharge & 20 to 25 & 240 & 770 & 1800 & 1700 & 1400 & 1300 & 940 & 1000 & 980 \\
\hline Discharge & 35 to 40 & 550 & 2000 & 3500 & 2700 & 1600 & 1200 & 960 & 910 & 850 \\
\hline Discharge & 0 to 5 & 250 & 880 & 1300 & 1000 & 1100 & 2700 & 1900 & 1300 & 690 \\
\hline Discharge & 20 to 25 & 290 & 920 & 2100 & 1700 & 1400 & 1700 & 1300 & 1000 & 730 \\
\hline Discharge & 35 to 40 & 510 & 1700 & 3200 & 2500 & 1500 & 800 & 660 & 680 & 790 \\
\hline Reference 1 & 0 to 5 & 1.9 & 6.1 & 9.9 & 12 & 8.7 & 9.3 & 9.5 & 6.7 & 5.7 \\
\hline Reference 1 & 20 to 25 & 1.3 & 4.2 & 3.1 & 0 & 0 & 7.5 & 8.7 & 7 & 3 \\
\hline Reference 1 . & 35 to 40 & 0.96 & 4.3 & 4.7 & 0 & 0 & 5.9 & 6.2 & 8.4 & 3.8 \\
\hline Reference 1 & 0 to 5 & 3.3 & 9.8 & 14 & 12 & 10 & 17 & 19 & 14 & 7.5 \\
\hline Reference 1 & 20 to 25 & 1.8 & 5.5 & 7.1 & 0 & 0 & 7.9 & 8.9 & 11 & 3.3 \\
\hline Reference 1 & 35 to 40 & 1.3 & 3.5 & 0 & 0 & 0 & 6.5 & 7.2 & 7.9 & 5.9 \\
\hline Reference 1 & 0 to 5 & 2.6 & 9.8 & 19 & 18 & 15 & 16 & 21 & 16 & 11 \\
\hline Reference 1 & 20 to 25 & 1.7 & 5.9 & 3.7 & 2.2 & 1.7 & 7.1 & 7.9 & 8.3 & 0 \\
\hline Reference 1 & 35 to 40 & 1.4 & 5.1 & 5.2 & 0 & 0 & 7 & 7.2 & 7.5 & 5.4 \\
\hline Reference 2 & 0 to 5 & 4.6 & 18 & 29 & 24 & 18 & 41 & 35 & 19 & 12 \\
\hline Reference 2 & 20 to 25 & 4.1 & 11 & 15 & 7 & 7.8 & 29 & 21 & 12 & 8.1 \\
\hline Reference 2 & 35 to 40 & 4.5 & 11 & 9.1 & 5.3 & 9.8 & 23 & 16 & 9.1 & 4.4 \\
\hline Reference 2 & 0 to 5 & 3.7 & 15 & 26 & 23 & 21 & 36 & 31 & 18 & 13 \\
\hline Reference 2 & 20 to 25 & 3 & 6.3 & 6.7 & 4.5 & 5.8 & 17 & 12 & 6.9 & 4.1 \\
\hline Reference 2 & 35 to 40 & 4 & 7.4 & 5.1 & 2.7 & 5 & 14 & 9.8 & 7.1 & 3.5 \\
\hline Reference 2 & 0 to 5 & 4.4 & 16 & 26 & 21 & 16 & 35 & 31 & 17 & 12 \\
\hline Reference 2 & 20 to 25 & 5.3 & 17 & 21 & 15 & 11 & 32 & 25 & 14 & 7.7 \\
\hline Reference 2 . & 35 to 40 & 3.6 & 6.6 & 4.5 & 3.2 & 4.9 & 12 & 9.2 & 6.4 & 3.8 \\
\hline $300 \mathrm{ft} \mathrm{NE}$ & 0 to 5 & 26 & 100 & 92 & 55 & 160 & 650 & 630 & 360 & 250 \\
\hline $500 \mathrm{ft} \mathrm{NE}$ & 0 to 5 & 8.9 & 29 & 52 & 51 & 38 & 140 & 100 & 48 & 29 \\
\hline $1000 \mathrm{ft} \mathrm{NE}$ & 0 to 5 & 2 & 6.6 & 11 & 11 & 8.1 & 13 & 16 & 9.7 & 8.4 \\
\hline $1000 \mathrm{ft} \mathrm{SE}$ & 0 to 5 & 3.5 & 13 & 23 & 24 & 15 & 27 & 26 & 16 & 13 \\
\hline $500 \mathrm{ft} \mathrm{SE}$ & 0 to 5 & 1.8 & 6 & 11 & 12 & 11 & 12 & 14 & 12 & 21 \\
\hline $100 \mathrm{ft} \mathrm{SW}$ & 0 to 5 & 18 & 52 & 130 & 160 & 110 & 130 & 110 & 86 & 87 \\
\hline $300 \mathrm{ft} \mathrm{SW}$ & 0 to 5 & 3.8 & 13 & 25 & 28 & 18 & 30 & 34 & 21 & 16 \\
\hline $500 \mathrm{ft} \mathrm{SW}$ & 0 to 5 & 1.8 & 7.1 & 11 & 12 & 9.8 & 18 & 22 & 13 & 9.3 \\
\hline $1000 \mathrm{ft} \mathrm{SW}$ & 0105 & 4.7 & 18 & 36 & 39 & 21 & 42 & 37 & 21 & 18 \\
\hline $100 \mathrm{ft}$ NW & 0105 & 33 & 99 & 340 & 470 & 320 & 210 & 190 & 170 & 150 \\
\hline $300 \mathrm{ft} \mathrm{NW}$ & 0 to 5 & 34 & 120 & 180 & 170 & 140 & 440 & 330 & 190 & 83 \\
\hline $500 \mathrm{ft} \mathrm{NW}$ & 0 to 5 & 8.4 & 28 & 55 & 56 & 39 & 62 & 53 & 34 & 26 \\
\hline $1000 \mathrm{tt} N W$ & 0 to 5 & 15 & 52 & 55 & 40 & 72 & 460 & 360 & 150 & 57 \\
\hline $100 \mathrm{ft}$ NE & 0 to 5 & 81 & 280 & 500 & 450 & 350 & 910 & 730 & 500 & 440 \\
\hline
\end{tabular}


Bay de Chene Sediment PAH

\begin{tabular}{|c|c|c|c|c|c|c|c|c|c|c|}
\hline Discharge & $\begin{array}{l}\text { Depth } \\
\text { (cm) } \\
0 \text { to } 5\end{array}$ & $\begin{array}{c}\text { C3F/P } \\
\text { ng/g } \\
380\end{array}$ & $\begin{array}{c}C O D \\
n g / g \\
99\end{array}$ & $\begin{array}{l}\text { C1D } \\
n g / g \\
180\end{array}$ & $\begin{array}{c}C 2 D \\
n g / g \\
370\end{array}$ & $\begin{array}{c}\text { C3D } \\
n g / g \\
380\end{array}$ & $\begin{array}{c}\mathrm{BAA} \\
\mathrm{ng} / \mathrm{g} \\
960\end{array}$ & $\begin{array}{c}\text { COC } \\
\text { ng/g } \\
1000\end{array}$ & $\begin{array}{c}\mathrm{ClC} \\
\mathrm{ng} / \mathrm{g} \\
430\end{array}$ & $\begin{array}{c}\mathrm{C} 2 \mathrm{C} \\
\mathrm{ng} / \mathrm{g} \\
320\end{array}$ \\
\hline Discharge & 20 to 25 & 400 & 66 & 200 & 430 & 460 & 470 & 600 & 300 & 290 \\
\hline Discharge & 35 to 40 & 660 & 69 & 500 & 950 & 960 & 330 & 470 & 290 & 370 \\
\hline Discharge & 0 to 5 & 3000 & 210 & 690 & 1500 & 1400 & 12000 & 11000 & 6400 & 2800 \\
\hline Discharge & 20 to 25 & 970 & 71 & 310 & 660 & 790 & 780 & 790 & 700 & 800 \\
\hline Discharge & 35 to 40 & 750 & 96 & 670 & 1300 & 1200 & 490 & 600 & 430 & 560 \\
\hline Discharge & 0 to 5 & 510 & 150 & 250 & 460 & 470 & 1400 & 1300 & 610 & 450 \\
\hline Discharge & 20 to 25 & 500 & 88 & 390 & 800 & 800 & 760 & 820 & 530 & 480 \\
\hline Discharge & 35 to 40 & 790 & 87 & 630 & 1200 & 1200 & 250 & 300 & 310 & 460 \\
\hline Reference 1 & 0 to 5 & 6.8 & 0.91 & 1.8 & 5.3 & 6.8 & 2.5 & 3.7 & 3.5 & 2.7 \\
\hline Reference 1 & 20 to 25 & 0 & 0 & 0 & 0 & 0 & h7 & 3.4 & 0 & 0 \\
\hline Reference 1 & 35 to 40 & 4.4 & 0 & 0 & 0 & 0 & 1.9 & 3.4 & 5.9 & 3.4 \\
\hline Reference 1 & 0 to 5 & 4.9 & 1.1 & 4 & 7.2 & 9.7 & 4 & 6 & 5.1 & 5.3 \\
\hline Reference 1 & 20 to 25 & 0 & 0 & 0 & 0 & 0 & 1.8 & 3.8 & 0 & 0 \\
\hline Reference 1 & 35 to 40 & 0 & 0 & 0 & 0 & 0 & 1.7 & 3.3 & 0 & 0 \\
\hline Reference 1 & 0 to 5 & 11 & 1.5 & 3.7 & 10 & 15 & 3.9 & 5.8 & 6 & 7.1 \\
\hline Reference 1 & 20 to 25 & 0 & 0 & 0 & 0 & 0 & 1.7 & 3.1 & 0 & 0 \\
\hline Reference 1 & 35 to 40 & 0 & 0 & 0 & 0 & 0 & 1.3 & 2.9 & 0 & 0 \\
\hline Reference 2 & 0 to 5 & 7 & 2.6 & 8.5 & 19 & 17 & 5.6 & 11 & 7.8 & 8.1 \\
\hline Reference 2 & 20 to 25 & 3.7 & 2.3 & 4.3 & 5.1 & 5.2 & 3.3 & 6.1 & 4 & 3 \\
\hline Reference 2 & 35 to 40 & 3.5 & 1.7 & 2.4 & 1.5 & 0 & 3.8 & 6 & 4.4 & 2.6 \\
\hline Reference 2 & 0 to 5 & 8.4 & 2.1 & 5.5 & 14 & 15 & 8.1 & 12 & 9.1 & 7.3 \\
\hline Reference 2 & 20 to 25 & 2.1 & 1.2 & 1.8 & 2.5 & 2.4 & 1.9 & 4 & 3.1 & 2.7 \\
\hline Relerence 2 & 35 to 40 & 2 & 1 & 0 & 0 & 0 & 1.6 & 3.4 & 2.8 & 2.2 \\
\hline Reference 2 & 0 to 5 & 9.2 & 2.3 & 5.6 & 12 & 13 & 5 & 9 & 9 & 8.3 \\
\hline Reference 2 & 20 to 25 & 6.1 & 3 & 5.3 & 8.9 & 7.9 & 4.3 & 7.5 & 5.8 & 5.6 \\
\hline Reference 2 & 35 to 40 & 1.8 & 0.87 & 0 & 1.1 & 0 & 1.7 & 2.9 & 1.9 & 1.5 \\
\hline $300 \mathrm{ft} \mathrm{NE}$ & 0 to 5 & 170 & 16 & 16 & 30 & 45 & 350 & 310 & 200 & 130 \\
\hline $500 \mathrm{ft}$ NE & 0 to 5 & 24 & 4.5 & 10 & 24 & 28 & 23 & 26 & 23 & 20 \\
\hline $1000 \mathrm{ftNE}$ & 0 to 5 & 6.5 & 1.1 & 2.5 & 5.3 & 6.4 & 3.2 & 4.9 & 5.6 & 5 \\
\hline $1000 \mathrm{ft} \mathrm{SE}$ & 0 to 5 & 11 & 1.6 & 4.4 & 10 & 13 & 5.4 & 8.6 & 7.9 & 9.1 \\
\hline $500 \mathrm{ft} \mathrm{SE}$ & 0 to 5 & 27 & 1 & 2.1 & 5.1 & 6.3 & 3.7 & 5.2 & 9 & 16 \\
\hline $100 \mathrm{ft} \mathrm{SW}$ & 0 to 5 & 68 & 9.1 & 26 & 68 & 78 & 40 & 55 & 42 & 48 \\
\hline $300 \mathrm{ft}$ SW & 0 to 5 & 14 & 1.8 & 4.8 & 12 & 14 & 8.6 & 10 & 9.1 & 11 \\
\hline $500 \mathrm{ft} \mathrm{SW}$ & 0 to 5 & 8.2 & 1 & 2.1 & 5.3 & 6.2 & 6.6 & 7.3 & 6.1 & 6.1 \\
\hline $1000 \mathrm{ft}$ SW & 0 to 5 & 16 & 2.3 & 6.2 & 17 & 19 & 1.4 & 12 & 11 & 13 \\
\hline $100 \mathrm{ft} \mathrm{NW}$ & 0 to 5 & 140 & 24 & 83 & 210 & 230 & 58 & 110 & 79 & 110 \\
\hline $300 \mathrm{ft} \mathrm{NW}$ & 0 to 5 & 72 & 19 & 34 & 72 & 76 & 100 & 190 & 84 & 57 \\
\hline $500 \mathrm{ft} \mathrm{NW}$ & 0 to 5 & 25 & 4.1 & 10 & 24 & 28 & 13 & 23 & 17 & 20 \\
\hline $1000 \mathrm{ft} \mathrm{NW}$ & 0105 & 33 & 7.2 & 9.8 & 18 & 19 & 190 & 150 & 66 & 31 \\
\hline $100 \mathrm{ft} \mathrm{NE}$ & 0 to 5 & 370 & 39 & 87 & 180 & 190 & 340 & 470 & 290 & 260 \\
\hline
\end{tabular}


Bay de Chene Sediment PAH

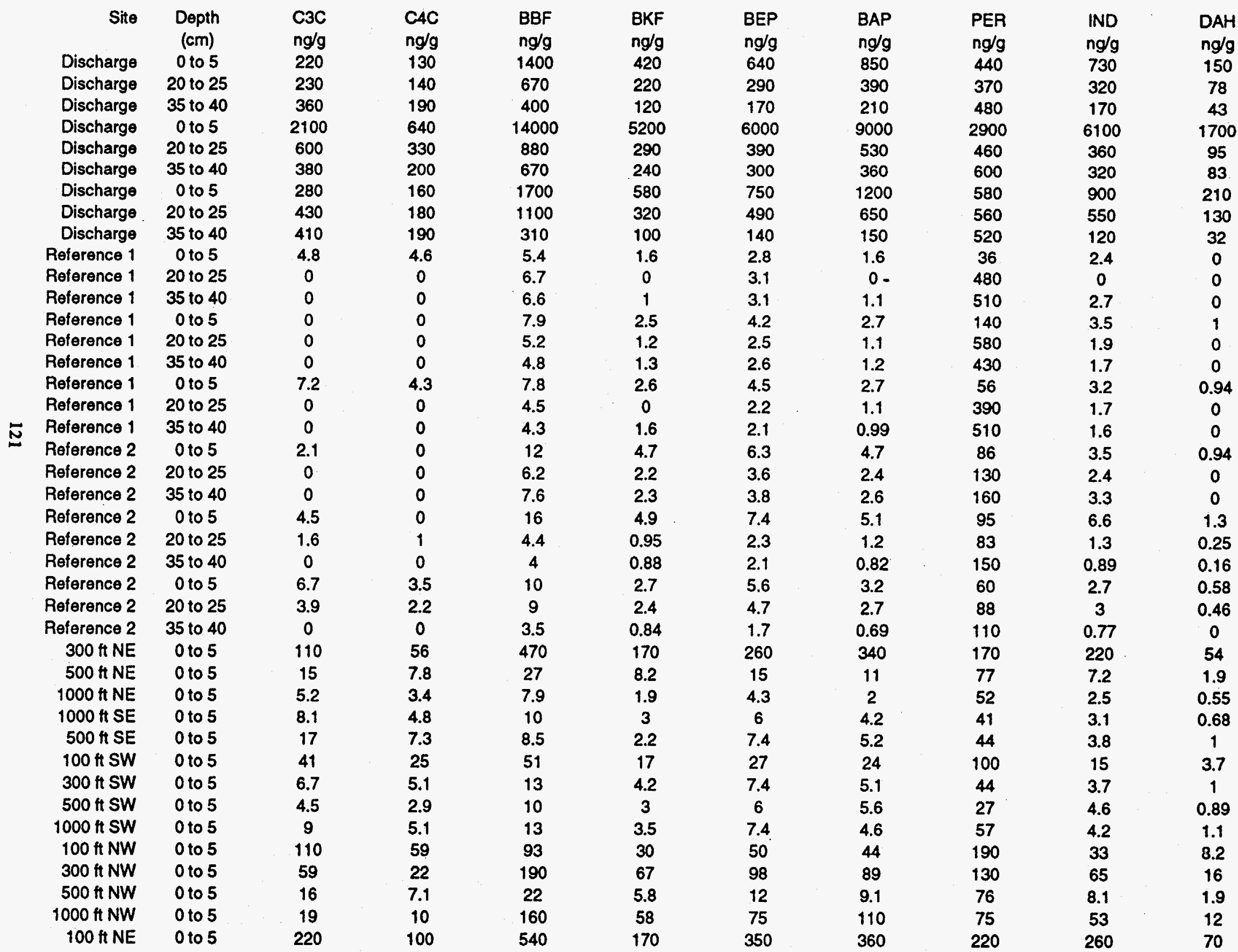




\begin{tabular}{|c|c|c|c|}
\hline Site & $\begin{array}{l}\text { Depth } \\
\text { (cm) }\end{array}$ & $\begin{array}{l}\text { BGP } \\
n g / g\end{array}$ & $\begin{array}{c}\text { Total PAH } \\
\text { ng/g }\end{array}$ \\
\hline Discharge & 0 to 5 & 630 & 23723.1 \\
\hline Discharge & 20 to 25 & 270 & 18003.4 \\
\hline Discharge & 35 to 40 & 140 & 35368.5 \\
\hline Discharge & 0105 & 4400 & 162152 \\
\hline Discharge & 20 to 25 & 290 & 28980.2 \\
\hline Discharge & 35 to 40 & 270 & 49963 \\
\hline Discharge & 0 to 5 & 740 & 32179 \\
\hline Discharge & 20 to 25 & 440 & 31482.1 \\
\hline Discharge & 35 to 40 & 110 & 43358.7 \\
\hline Reference 1 & 0 to 5 & 4.7 & 188.11 \\
\hline Reference 1 & 20 to 25 & 4.6 & 570.7 \\
\hline Reference 1 & 35 to 40 & 4.3 & 601.94 \\
\hline Reference 1 & 0 to 5 & 5.2 & 397.9 \\
\hline Reference 1 & 20 to 25 & 3.3 & 684.9 \\
\hline Reference 1 & 35 to 40 & 3.1 & 492.6 \\
\hline Reference 1 & 0 to 5 & 4.3 & 337.54 \\
\hline Relerence 1 & 20 to 25 & 2.7 & 480.3 \\
\hline Reference 1 & 35 to 40 & 2.4 & 587.89 \\
\hline Reference 2 & 0 to 5 & 5.5 & 529.94 \\
\hline Reference 2 & 20 to 25 & 3.2 & 371.35 \\
\hline Reference 2 & 35 to 40 & 4.1 & 368.4 \\
\hline Reference 2 & 0 to 5 & 7.7 & 515.83 \\
\hline Reference 2 & 20 to 25 & 1.9 & 236.66 \\
\hline Reference 2 & 35 to 40 & 1.5 & 283.51 \\
\hline Reference 2 & 0 to 5 & 4.1 & 456.48 \\
\hline Reference 2 & 20 to 25 & 7.1 & 423.65 \\
\hline Reference 2 & 35 to 40 & 1.9 & 234.37 \\
\hline $300 \mathrm{ft} \mathrm{NE}$ & 0 to 5 & 250 & 6336.1 \\
\hline $500 \mathrm{ft} \mathrm{NE}$ & 0 to 5 & 10 & 1025.17 \\
\hline $1000 \mathrm{HNE}$ & 0 to 5 & 3.7 & 258.73 \\
\hline $1000 \mathrm{ft} \mathrm{SE}$ & 0 to 5 & 5.2 & 394.63 \\
\hline $500 \mathrm{HISE}$ & 0 to 5 & 8 & 319.07 \\
\hline $100 \mathrm{ft} \mathrm{SW}$ & 0 to 5 & 19 & 2157.39 \\
\hline $300 \mathrm{ft} \mathrm{SW}$ & 0 to 5 & 5.5 & 454.56 \\
\hline 500 th SW & 0 to 5 & 6 & 276.83 \\
\hline $1000 \mathrm{ft} \mathrm{SW}$ & 0 to 5 & 5.5 & 565.25 \\
\hline $100 \mathrm{ft} \mathrm{NW}$ & 0 to 5 & 39 & 5369.5 \\
\hline $300 \mathrm{ft} \mathrm{NW}$ & 0 to 5 & 78 & 4075.1 \\
\hline $500 \mathrm{ft} \mathrm{NW}$ & 0 to 5 & 10 & 877.09 \\
\hline $1000 \mathrm{ft} \mathrm{NW}$ & 0 to 5 & 56 & 2616.03 \\
\hline $100 \mathrm{ftNE}$ & 0 to 5 & 380 & 11576.7 \\
\hline
\end{tabular}


Table A-4. Metals in sediment collented at Delacroix Island and Bay De Chene

\begin{tabular}{|c|c|c|c|c|c|c|c|c|c|c|c|c|c|c|c|c|c|}
\hline & A & $\bar{B}$ & C & D & $E$ & $F$ & $\mathbf{G}$ & H & $I$ & $\mathrm{~J}$ & $\bar{K}$ & $L$ & $M$ & $\mathbf{N}$ & $\overline{0}$ & $\bar{P}$ & $\bar{a}$ \\
\hline 1 & Site/Samplo & & A & As & Ba & $\mathrm{Ca}$ & Cd & $\mathrm{Cr}$ & $\mathrm{Cu}$ & Fo & $\mathrm{Hg}$ & $\mathrm{Mn}$ & Mo & $\mathbf{N I}$ & $\mathrm{PD}$ & IV & $\mathrm{Zn}$ \\
\hline 2 & Bay de Chene & & (\%) & $(\mathrm{ppm})$ & $(\mathrm{ppm})$ & $(\%)$ & $(\mathrm{ppm})$ & (ppm) & (ppm) & (ppm) & $(\mathrm{ppm})$ & $(\mathrm{ppm})$ & (ppm) & $(p p m)$ & (ppm) & (ppm) & $(\mathrm{ppm})$ \\
\hline 3 & Discharge A & & 5.81 & 11.0 & 1370 & 0.83 & 0.43 & 55.30 & 21.8 & 2.98 & 0.172 & 534 & 1.2 & 24.6 & 35.6 & 91.0 & 112.0 \\
\hline 4 & B & & 5.24 & 10.6 & 466 & 0.97 & 0.34 & 50.60 & 21.3 & 2.82 & 0.423 & 474 & 1.2 & 22.3 & 19.5 & 91.7 & 102.0 \\
\hline 5 & B & & 5.05 & 9.9 & 1790 & 0.78 & 0.29 & 49.80 & 19.5 & 2.73 & - & 454 & 1.1 & 21.9 & 22.8 & 75.9 & 101.0 \\
\hline 6 & B) & & 5.00 & 9.7 & 162 & 0.82 & 0.36 & 42.00 & 19.0 & 2.66 & $E$ & 457 & 1.1 & 21.6 & 12.1 & 76.8 & 99.3 \\
\hline 7 & & average B & 5.10 & 10.07 & 806.00 & 0.86 & 0.33 & 47.47 & 19.93 & 2.74 & 0.42 & 461.67 & 1.13 & 21.93 & 18.13 & 81.47 & 100.7 \\
\hline 8 & C. & & 5.77 & 11.9 & 673 & 0.90 & 0.46 & 56.80 & 27.5 & 3.13 & 0.187 & 561 & 1.3 & 26.0 & 29.8 & 93.7 & 152.0 \\
\hline 9 & Discherge & $\operatorname{Mean}(3 * s)$ & 5.56 & 10.99 & 949.67 & 0.86 & 0.41 & 53.19 & 23.08 & 2.95 & 0.26 & 518.89 & 1.21 & 24.18 & 27.84 & 88.72 & 121.59 \\
\hline 10 & & SD & 0.40 & 0.92 & 370.04 & 0.04 & 0.07 & 5.01 & 3.94 & 0.20 & 0.14 & 51.36 & 0.08 & 2.07 & 8.90 & 6.43 & 26.93 \\
\hline 11 & Reference iA & & 4.09 & 8.6 & 1090 & 15.30 & 0.25 & 40.30 & 13.6 & 2.04 & 0.047 & 354 & 1.8 & 16.0 & 16.7 & 66.8 & 56.4 \\
\hline 12 & R1B & & 5.97 & 9.1 & 934 & 5.39 & 0.33 & 56.40 & 19.1 & 2.84 & 0.041 & 313 & 2.3 & 23.6 & 19.9 & 100.0 & 84.0 \\
\hline 13 & A1C & & 5.58 & 8.3 & 1100 & 1.95 & 0.35 & 52.30 & 18.3 & 2.78 & 0.052 & 370 & 2.0 & 22.2 & 23.7 & 85.1 & 74.5 \\
\hline 14 & R1 & Mean & 5.21 & 8.67 & 1041.33 & 7.55 & 0.31 & 49.67 & 17.00 & 2.55 & 0.05 & 345.67 & 2.03 & 20.60 & 20.10 & 83.97 & 71.63 \\
\hline 15 & & So & 0.99 & 0.40 & 93.09 & 6.93 & 0.05 & 8.37 & 2.97 & 0.45 & 0.01 & 29.40 & 0.25 & 4.04 & 3.50 & 16.63 & 14.02 \\
\hline 16 & Reterence 2A & & 4.95 & 5.7 & 753 & 1.13 & 0.23 & 42.70 & 15.3 & 2.29 & 0.049 & 454 & 1.1 & 19.6 & 18.9 & 75.4 & 68.3 \\
\hline 17 & $\mathrm{P} 2 \mathrm{~B}$ & & 5.47 & 7.7 & 850 & 1.13 & 0.32 & 49.90 & 16.1 & 2.51 & 0.046 & 421 & 1.6 & 20.7 & 21.5 & 73.1 & 76.5 \\
\hline 18 & $\mathrm{~A} 2 \mathrm{C}$ & & 6.07 & 9.0 & 621 & 1.03 & 0.36 & 53.10 & 19.9 & 2.91 & 0.047 & 479 & 1.7 & 24.3 & 22.4 & 95.6 & 87.0 \\
\hline 19 & R2. & Mean & 5.50 & 7.47 & 741.33 & 1.10 & 0.30 & 48.57 & 17.10 & 2.57 & 0.05 & 451.33 & 1.47 & 21.53 & 20.93 & 81.37 & 77.27 \\
\hline 20 & & SD & 0.56 & 1.66 & 114.94 & 0.06 & 0.07 & 5.33 & 2.46 & 0.31 & 0.00 & 29.09 & 0.32 & 2.46 & 1.82 & 12.38 & 9.37 \\
\hline 21 & $100 \mathrm{NW}$ & & 6.35 & 10.3 & 1370 & 0.70 & 0.40 & 58.70 & 23.9 & 3.25 & 0.072 & 427 & 1.2 & 27.7 & 27.2 & 99.9 & 109.0 \\
\hline 22 & $100 \mathrm{NW}$ & & 6.38 & 11.3 & 990 & 0.75 & 0.41 & 62.70 & 24.9 & 3.36 & - & 440 & 1.2 & 28.7 & 27.3 & 115.0 & 115.0 \\
\hline 23 & $100 \mathrm{NW}$ & & 6.44 & 9.7 & 570 & 0.67 & 0.41 & 59.50 & 24.2 & 3.30 & $E$ & 433 & 1.2 & 28.1 & 25.6 & 109.0 & 109.0 \\
\hline 24 & $100 \mathrm{NW}$ & Mean & 6.39 & 10.43 & 976.67 & 0.71 & 0.41 & 60.30 & 24.33 & 3.30 & 0.07 & 433.33 & 1.20 & 28.17 & 26.70 & 107.97 & $111 . \infty$ \\
\hline 25 & & SD & 0.05 & 0.81 & 400.17 & 0.04 & 0.01 & 2.12 & 0.51 & 0.06 & & 6.51 & 0.00 & 0.50 & 0.95 & 7.60 & 3.46 \\
\hline 26 & $300 \mathrm{NW}$ & & 5.22 & 13.9 & 691 & 0.66 & 0.46 & 48.50 & 23.5 & 2.98 & 0.083 & 505 & 1.3 & 25.7 & 24.9 & 86.5 & 93.0 \\
\hline 27 & $500 N W$ & & 6.21 & 8.7 & 1330 & 0.99 & 0.34 & 54.10 & 18.6 & 2.77 & 0.052 & 357 & 1.4. & 23.9 & 23.1 & 86.4 & 88.4 \\
\hline 28 & $1000 \mathrm{NW}$ & & 5.64 & 7.7. & 771 & 1.22 & 0.27 & 48.00 & 15.3 & 2.24 & 0.042 & 312 & 1.4 & 18.6 & 26.3 & 77.9 & 70.8 \\
\hline 29 & $100 S W$ & & 6.45 & 7.3 & 1320 & 0.76 & 0.39 & 58.90 & 20.9 & 2.96 & 1.400 & 380 & 1.1 & 25.3 & 24.6 & 101.0 & 102.0 \\
\hline 30 & $3005 w$ & & 5.82 & 8.0 & 1310 & 1.80 & 0.29 & 53.70 & 18.5 & 2.79 & 0.098 & 386 & 2.0 & 22.8 & 22.2 & 84.0 & 82.3 \\
\hline 31 & $500 S W$ & & 5.38 & 6.8 & 1350 & 1.24 & 0.28 & 45.30 & 13.2 & 2.16 & 0.088 & 291 & 1.6 & 19.9 & 19.6 & 68.6 & 93.7 \\
\hline 32 & $1000 \mathrm{SW}$ & & 6.06 & 5.9 & 1100 & 1.08 & 0.33 & 53.30 & 17.2 & 2.74 & 0.040 & 344 & 1.7 & 22.9 & 22.1 & 93.2 & 84.3 \\
\hline 33 & $100 \mathrm{NE}$ & & 5.89 & 11.4 & 1090 & 0.87 & 0.55 & 53.40 & 26.6 & 3.10 & 0.065 & 524 & 1.4 & 26.0 & 35.3 & 89.3 & 158.0 \\
\hline 34 & 100NE & & 5.84 & 5.3 & 1460 & 1.05 & 0.42 & 63.80 & 28.8 & 3.08 & 0.096 & 519 & 1.2 & 31.7 & 28.3 & 89.5 & 121.0 \\
\hline 35 & $100 \mathrm{NE}$ & & 5.48 & 5.8 & 1360 & 1.05 & 0.52 & 54.60 & 30.1 & 3.13 & 0.133 & 518 & 1.6 & 28.8 & 32.4 & 86.8 & 159.0 \\
\hline 36 & $100 \mathrm{NE}$ & Mean & 5.74 & 7.50 & 1303.33 & 0.99 & 0.50 & 57.27 & 28.50 & 3.10 & 0.10 & 520.33 & 1.40 & 28.83 & 32.00 & 88.53 & 146.00 \\
\hline 37 & & SD & 0.22368 & 3.38674 & 191.3984 & 0.10392 & 0.06807 & 5.68976 & 1.76918 & 0.02517 & 0.03404 & 3.21455 & 0.2 & 2.85015 & 3.5171 & 1.50444 & 21.6564 \\
\hline 38 & $300 \mathrm{NE}$ & & 5.74 & 7.3 & 1560 & 1.68 & 0.46 & 55.50 & 21.5 & 2.96 & 0.500 & 460 & 2.2 & 22.2 & 33.3 & 83.2 & 105.0 \\
\hline 39 & $300 \mathrm{NE}$ & & 5.56 & 4.6 & 1670 & 2.59 & 0.32 & 59.20 & 21.2 & 2.57 & 0.072 & 372 & 4.0 & 24.7 & 25.4 & 89.3 & 77.0 \\
\hline 40 & $300 \mathrm{NE}$ & & 5.51 & 6.2 & 65.1 & 1.53 & 0.32 & 54.90 & 20.8 & 3.07 & 0.064 & 376 & 3.7 & 28.4 & 19.4 & 91.7 & 81.9 \\
\hline 41 & 300NE & Mean & 5.60 & 6.03 & 1098.37 & 1.93 & 0.37 & 56.53 & 21.17 & 2.87 & 0.21 & 402.67 & 3.30 & 25.10 & 26.03 & 88.07 & 87.97 \\
\hline 42 & & SD & 0.12 & 1.36 & 896.52 & 0.57 & 0.08 & 2.33 & 0.35 & 0.26 & 0.25 & 49.69 & 0.96 & 3.12 & 6.97 & 4.38 & 14.95 \\
\hline 43 & & & & & & & & & & & & & & & & & \\
\hline 44 & & & & & & & & & & & & & & & & & \\
\hline
\end{tabular}




\begin{tabular}{|c|c|c|c|c|c|c|c|c|c|c|c|c|c|c|c|c|c|}
\hline & $\bar{A}$ & $\bar{B}$ & C & $\bar{D}$ & $E$ & $F$ & 5 & $\mathrm{H}$ & 1 & $J$ & $\mathbf{K}$ & $L$ & $\bar{M}$ & $\mathbf{N}$ & 0 & $\bar{P}$ & 0 \\
\hline 45 & Slte/Sample & & Al & As & $\mathrm{Ba}$ & $\overline{\mathrm{Ca}}$ & $\mathrm{Cd}$ & $C_{r}$ & $\mathrm{Cu}$ & $F_{\theta}$ & $\mathrm{Hg}$ & $\mathrm{Mn}$ & Mo & $\mathrm{NI}$ & $\mathrm{Pb}$ & V & $Z n$ \\
\hline 46 & Bay de Chene & & $(\%)$ & (ppm) & (ppm) & $(\%)$ & (ppm) & (ppm) & (ppm) & (ppm) & $(p p m)$ & $(\mathrm{ppm})$ & (ppm) & (ppm) & (ppm) & (ppm) & $(\mathrm{ppm})$ \\
\hline 47 & $500 \mathrm{NE}$ & & 5.42 & 6.9 & 947 & 0.54 & 0.26 & 49.70 & 17.4 & 2.55 & 0.034 & 285 & 1.1 & 21.1 & 20.1 & 87.3 & 84.4 \\
\hline 48 & $500 \mathrm{NE}$ & & 6.73 & 5.6 & 1260 & 0.86 & 0.35 & 66.60 & 23.5 & 3.28 & 0.061 & 448 & 1.2 & 31.8 & 23.2 & 102.0 & 98.6 \\
\hline 49 & $500 \mathrm{NE}$ & & 6.83 & 6.6 & 1120 & 0.63 & 0.34 & 64.20 & 23.5 & 3.37 & 0.058 & 591 & 1.0 & 32.1 & 24.3 & 103.0 & 103.0 \\
\hline 50 & $500 \mathrm{NE}$ & Mean & 6.33 & 6.37 & 1109.00 & 0.68 & 0.32 & 60.17 & 21.47 & 3.07 & 0.05 & 441.33 & 1.10 & 28.33 & 22.53 & 97.43 & 95.33 \\
\hline 51 & & SD & 0.79 & 0.68 & 156.79 & 0.17 & 0.05 & 9.14 & 3.52 & 0.45 & 0.01 & 153.11 & 0.10 & 6.27 & 2.18 & 8.79 & 9.72 \\
\hline 52 & $1000 \mathrm{NE}$ & & 6.55 & 8.0 & 979 & 1.17 & 0.34 & 59.00 & 20.6 & 3.09 & 0.045 & 329 & 1.7 & 26.1 & 22.4 & 105.0 & 90.3 \\
\hline 53 & $1000 \mathrm{NE}$ & b & 5.94 & 6.4 & 1140 & 1.47 & 0.25 & 56.10 & 20.0 & 2.87 & 0.044 & 321 & 1.4 & 31.0 & 18.9 & 85.6 & 73.2 \\
\hline 54 & $1000 \mathrm{NE}$ & b & 5.94 & 4.7 & 325 & 2.14 & 0.21 & 55.60 & 18.2 & 2.69 & 0.042 & 317 & 1.3 & 27.1 & 16.7 & 82.2 & 68.7 \\
\hline 55 & $1000 \mathrm{NE}$ & $\mathrm{b}$ & 5.61 & 4.7 & 1060 & 2.36 & 0.23 & 54.20 & 17.9 & 2.59 & 0.042 & 309 & 1.2 & 25.6 & 18.5 & 82.1 & 67.8 \\
\hline 56 & & Average b & 5.83 & 5.27 & 841.67 & 1.99 & 0.23 & 55.30 & 18.70 & 2.72 & 0.04 & 315.67 & 1.30 & 27.90 & 18.03 & 83.30 & 69.90 \\
\hline 57 & $1000 \mathrm{NE}$ & & 6.77 & 6.4 & 1000 & 1.15 & 0.23 & 66.70 & 22.3 & 3.12 & 0.047 & 283 & 1.3 & 30.2 & 20.1 & 104.0 & 86.7 \\
\hline 58 & $1000 \mathrm{NE}$ & Mean (3 \#s) & 6.38 & 6.56 & 940.22 & 1.44 & 0.27 & 60.33 & 20.53 & 2.98 & 0.04 & 309.22 & 1.43 & 28.07 & 20.18 & 97.43 & 82.30 \\
\hline 59 & & $S D$ & 0.49 & 1.37 & 86.00 & 0.48 & 0.06 & 5.82 & 1.80 & 0.22 & 0.00 & 23.67 & 0.23 & 2.06 & 2.18 & 12.25 & 10.89 \\
\hline 60 & 500SE & & 3.97 & 6.1 & 832 & 12.30 & 0.20 & 32.20 & 10.8 & 1.73 & 0.029 & 387 & 0.9 & 14.0 & 14.0 & 53.4 & 51.8 \\
\hline 61 & 1000SE & & 5.55 & 7.8 & 1120 & 1.50 & 0.39 & 49.00 & 15.5 & 2.43 & 0.400 & 440 & 1.1 & 20.3 & 20.5 & 77.4 & 77.5 \\
\hline 62 & Site/Sample & & Al & As & $\mathrm{Ba}$ & $\mathrm{Ca}$ & $\mathrm{Cd}$ & $\mathrm{Cr}$ & $\mathrm{Cu}$ & $F_{\theta}$ & $\mathrm{Hg}$ & Mn & Mo & $\mathrm{Ni}$ & $\overline{\mathrm{Pb}}$ & v & $\mathrm{Zn}$ \\
\hline 63 & DELACROIXI. & & $(\%)$ & (ppm) & $(\mathrm{ppm})$ & $(\%)$ & (ppm) & (ppm) & (ppm) & $(\mathrm{ppm})$ & $(\mathrm{ppm})$ & (ppm) & $(\mathrm{ppm})$ & (ppm) & (ppm) & (ppm) & (ppm) \\
\hline 64 & Dlscharge A & & 6.04 & 11.2 & 350 & 0.88 & 0.25 & 56.10 & 23.4 & 3.49 & 0.063 & 1160 & 1.4 & 34.4 & 24.6 & 101.0 & 101.0 \\
\hline 65 & $\mathrm{~B}$ & & 5.80 & 10.7 & 1380 & 0.83 & 0.24 & 54.10 & 22.3 & 3.26 & 0.067 & 948 & 1.4 & 32.4 & 27.4 & 94.2 & 98.9 \\
\hline 66 & c & & 5.86 & 10.2 & 358 & 0.82 & 0.26 & 56.00 & 22.7 & 3.30 & 0.075 & 1196 & 1.3 & 1.3 & 21.2 & 101.0 & 97.2 \\
\hline 67 & Discharge & Mean & 5.90 & 10.70 & 696.00 & 0.84 & 0.25 & 55.40 & 22.80 & 3.35 & 0.07 & 1101.33 & 1.37 & 22.70 & 24.40 & 98.73 & 99.03 \\
\hline 68 & & SD & 0.12 & 0.50 & 592.37 & 0.03 & 0.01 & 1.13 & 0.56 & 0.12 & 0.01 & 134.00 & 0.06 & 18.56 & 3.10 & 3.93 & 1.90 \\
\hline 69 & Reference 1A & & 5.62 & 4.7 & 994 & 1.09 & 0.20 & 54.00 & 17.3 & 2.66 & 0.045 & 535 & 1.3 & 25.8 & 23.8 & 85.2 & 83.4 \\
\hline 70 & R1A & & 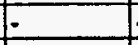 & . & E & E. & - & $=$ & - & - & 0.048 & - & - & F & - & + & $\because$ \\
\hline 71 & R1A & & - & $=$ & E & - & - & - & - & $E$ & 0.047 & - & L- & - & - & E. & - \\
\hline 72 & & R1A mean & & & & & & & & & 0.047 & & & & & & \\
\hline 73 & R1B & & 5.50 & 5.0 & 1071 & 1.09 & 0.17 & 47.30 & 14.6 & 2.33 & 0.041 & 606 & 0.9 & 23.9 & 22.1 & 71.6 & 73.6 \\
\hline 74 & R1C & & 5.56 & 4.5 & 1010 & 0.90 & 0.19 & 50.60 & 17.1 & 2.57 & 0.046 & 653 & 1.0 & 25.6 & 23.9 & 76.7 & 75.1 \\
\hline 75 & R1 & Mean & 5.56 & 4.73 & 1025.00 & 1.03 & 0.19 & 50.63 & 16.33 & 2.52 & 0.045 & 598.00 & 1.07 & 25.10 & 23.27 & 77.83 & 77.37 \\
\hline 76 & & SD & 0.06 & 0.25 & 40.63 & 0.11 & 0.02 & 3.35 & 1.50 & 0.17 & 0.003 & 59.41 & 0.21 & 1.04 & 1.01 & 6.87 & 5.28 \\
\hline 77 & site/Sample & & Al & As & $\mathrm{Ba}$ & $\mathrm{Ca}$ & $\mathrm{Cd}$ & $\mathrm{Cr}_{\mathrm{r}}$ & $\mathrm{Cu}$ & $\mathrm{Fo}$ & $\mathrm{Hg}$ & $\mathrm{Mn}$ & Mo & $\mathrm{Ni}$ & $\mathrm{Pb}$ & v & $\mathrm{Zn}$ \\
\hline 78 & DELACROIXI. & & $(\%)$ & (ppm) & (ppm) & $(\%)$ & (ppm) & $(p p m)$ & $(\mathrm{ppm})$ & (ppm) & (ppm) & (ppm) & (ppm) & (ppm) & $(\mathrm{ppm})$ & (ppm) & (ppm) \\
\hline 79 & R2A & & 4.70 & 3.2 & 1340 & 1.10 & 0.04 & 36.20 & 9.9 & 1.84 & 0.030 & 515 & 0.7 & 19.0 & 18.2 & 58.7 & 55.8 \\
\hline 80 & A2B & & 4.85 & 4.2 & 1430 & 1.05 & 0.11 & 45.70 & 11.6 & 1.95 & 0.033 & 443 & 0.9 & 20.8 & 19.3 & 59.4 & 57.4 \\
\hline 81 & A2B & & 4.93 & 4.6 & 1410 & 1.02 & 0.11 & 41.00 & 12.4 & 1.94 & . & 441 & 1.0 & 21.1 & 18.6 & 57.6 & 58.4 \\
\hline 82 & $\mathrm{R} 2 \mathrm{~B}$ & & 4.92 & 4.2 & 1290 & 1.01 & 0.19 & 42.30 & 11.7 & 1.92 & . & 447 & 1.0 & 21.1 & 19.3 & 55.4 & 59.2 \\
\hline 83 & R2B & average & 4.90 & 4.33 & 1376.67 & 1.03 & 0.14 & 43.00 & 11.90 & 1.94 & 0.033 & 443.67 & 0.97 & 21.00 & 19.07 & 57.47 & 58.33 \\
\hline 84 & R2C & & 4.79 & 3.2 & 1330 & 1.03 & 0.08 & 38.40 & 9.7 & 1.77 & 0.030 & 416 & 0.9 & 20.0 & 18.0 & 51.6 & 55.0 \\
\hline 85 & R2 & Mean (3its) & 4.80 & 3.58 & 1348.89 & 1.05 & 0.09 & 39.20 & 10.50 & 1.85 & 0.031 & 458.22 & 0.86 & 20.00 & 18.42 & 55.92 & 56.38 \\
\hline 86 & & SD & 0.10 & 0.65 & 24.57 & 0.04 & 0.05 & 3.47 & 1.22 & 0.08 & 0.002 & 51.08 & 0.14 & 1.00 & 0.57 & 3.79 & 1.74 \\
\hline 87 & 10005 & & 4.79 & 3.2 & 283 & 3.96 & 0.17 & 41.20 & 11.0 & 1.80 & 0.028 & 430 & 0.8 & 17.7 & 12.7 & 56.6 & 57.9 \\
\hline 88 & & & & & & & & & & & & & & & & & \\
\hline
\end{tabular}




\begin{tabular}{|c|c|c|c|c|c|c|c|c|c|c|c|c|c|c|c|c|c|}
\hline & $\bar{A}$ & $\overline{\mathbf{B}}$ & C & $\bar{D}$ & $\bar{E}$ & $\bar{F}$ & $\mathbf{G}$ & $\mathrm{H}$ & $T$ & $\mathrm{~J}$ & $K$ & $L$ & $M$ & $\mathbf{N}$ & 0 & $\mathbf{P}$ & $\mathbf{a}$ \\
\hline 89 & Site/Sample & & Al & As & $\mathrm{Ba}$ & $\mathrm{Ca}$ & Cd & $\mathrm{Cr}$ & $\mathrm{Cu}$ & $\mathrm{Fe}$ & $\mathrm{Hg}$ & $M n$ & Mo & $\mathrm{Ni}$ & $\mathrm{Pb}$ & V & $\mathrm{Zn}$ \\
\hline 90 & DELACROIX 1. & & $(\%)$ & (ppm) & (ppm) & $(\%)$ & (ppm) & (ppm) & $(\mathrm{ppm})$ & (ppm) & (ppm) & $(\mathrm{ppm})$ & (ppm) & (ppm) & $(\mathrm{ppm})$ & $(\mathrm{ppm})$ & $(\mathrm{ppm})$ \\
\hline 91 & 5005 & & 4.84 & 4.0 & 1220 & 1.04 & 0.07 & 36.00 & 9.8 & 1.70 & 0.032 & 340 & 0.7 & 17.6 & 16.1 & 55.9 & 51.8 \\
\hline 92 & $500 \mathrm{~s}$ & & - & E & $E$ & - & - & - & - & - & 0.030 & E & - & 1. & - & - & - \\
\hline 93 & 5005 & &. & - & $E$ & E & $E$ & - & {$[-$} & - & 0.031 & - & {$\left[\begin{array}{lll}- & & l \\
-1\end{array}\right.$} & - & - & - & - \\
\hline 94 & 3005 & & 4.73 & 3.5 & 933 & 1.13 & 0.07 & 36.50 & 9.2 & 1.54 & 0.029 & 274 & 0.7 & 15.3 & 13.8 & 42.4 & 52.4 \\
\hline 95 & 1005 & & 4.46 & 3.7 & 1170 & 1.18 & 0.07 & 35.60 & 8.7 & 1.46 & 0.024 & 378 & 0.6 & 15.6 & -14.8 & 35.6 & 47.5 \\
\hline 96 & 1000NW & & 3.90 & 3.8 & 2850 & 6.79 & 0.05 & 29.50 & 8.8 & 1.43 & 0.230 & 406 & 1.0 & 14.6 & 13.7 & 42.3 & 46.5 \\
\hline 97 & $1000 N W$ & & 2.79 & 5.1 & 73.7 & 3.84 & 0.17 & 28.90 & 12.7 & 2.59 & 0.038 & 396 & 2.2 & 16.7 & 4.1 & 44.3 & 45.2 \\
\hline 98 & $1000 \mathrm{NW}$ & & 3.23 & 5.4 & 299 & 3.20 & 0.10 & 29.90 & 10.7 & 1.09 & 0.027 & 295 & 1.6 & 14.1 & 6.1 & 46.3 & 30.0 \\
\hline 99 & $1000 \mathrm{NW}$ & Mean & 3.31 & 4.77 & 1074.23 & 4.61 & 0.11 & 29.43 & 10.73 & 1.70 & 0.10 & 365.67 & 1.60 & 15.13 & 7.97 & 44.30 & 40.57 \\
\hline 100 & & SD & 0.56 & 0.85 & 1541.98 & 1.91 & 0.06 & 0.50 & 1.95 & 0.79 & 0.11 & 61.40 & 0.60 & 1.38 & 5.06 & 2.00 & 9.17 \\
\hline 101 & $500 \mathrm{NW}$ & & 5.00 & 3.1 & 1330 & 1.05 & 0.07 & 40.30 & 10.5 & 1.78 & 0.028 & 325 & 0.8 & 19.5 & 16.9 & 50.5 & 57.4 \\
\hline 102 & $500 \mathrm{NW}$ & & 4.97 & 4.1 & 482 & 1.03 & 0.11 & 35.90 & 11.2 & 1.78 & - & 316 & 0.8 & 18.8 & 13.4 & 41.7 & 55.2 \\
\hline 103 & $500 \mathrm{NW}$ & & 5.02 & 3.8 & 349 & 1.06 & 0.15 & 40.90 & 10.9 & 1.80 & I- & 329 & 0.7 & 18.6 & 11.7 & 45.5 & 57.6 \\
\hline 104 & $500 \mathrm{NW}$ & & 5.55 & 5.2 & 686 & 1.03 & 0.30 & 47.90 & 13.9 & 2.29 & 0.043 & 489 & 0.9 & 26.3 & 16.1 & 73.5 & 65.0 \\
\hline 105 & $500 \mathrm{NW}$ & & 5.14 & 3.9 & 1760 & 1.10 & 0.24 & 44.10 & 11.5 & 1.84 & 0.032 & 382 & 0.8 & 22.6 & 16.0 & 60.5 & 54.9 \\
\hline 106 & $500 \mathrm{NW}$ & Mean & 5.14 & 4.02 & 921.40 & 1.05 & 0.17 & 41.82 & 11.60 & 1.90 & 0.03 & 368.20 & 0.80 & 21.16 & 14.82 & 54.34 & 58.02 \\
\hline 107 & & SD & 0.24 & 0.76 & 601.32 & 0.03 & 0.09 & 4.48 & 1.34 & 0.22 & 0.01 & 72.30 & 0.07 & 3.29 & 2.19 & 12.82 & 4.09 \\
\hline 108 & $300 \mathrm{NW}$ & & 5.66 & 5.6 & 834 & 4.39 & 0.25 & 51.90 & 17.3 & 2.19 & 0.030 & 370 & 0.9 & 22.6 & 17.1 & 81.5 & 72.0 \\
\hline 109 & $300 \mathrm{NW}$ & b & 5.55 & 5.3 & 1270 & 1.45 & 0.33 & 49.40 & 15.7 & 2.13 & 0.032 & 378 & 0.9 & 26.5 & 18.1 & 74.1 & 61.0 \\
\hline 110 & $300 N W$ & $b$ & 5.63 & 5.2 & 1130 & 1.46 & 0.27 & 50.60 & 15.5 & 2.15 & 0.031 & 375 & 0.8 & 24.4 & 15.7 & 72.9 & 65.9 \\
\hline 111 & $300 N W$ & $\mathrm{~b}$ & 5.72 & 7.2 & 1160 & 1.37 & 0.31 & 52.10 & 15.1 & 2.20 & 0.030 & 379 & 0.9 & 27.0 & 16.3 & 75.7 & 64.4 \\
\hline 112 & & Average b & 5.63 & 5.90 & 1186.67 & 1.43 & 0.30 & 50.70 & 15.43 & 2.16 & 0.03 & 377.33 & 0.87 & 25.97 & 16.70 & 74.23 & 63.77 \\
\hline 113 & $300 \mathrm{NW}$ & & 5.19 & 7.5 & 1220 & 1.34 & 0.30 & 47.00 & 12.4 & 2.10 & 0.035 & 620 & 0.8 & 25.6 & 16.1 & 65.9 & 57.5 \\
\hline 114 & $300 \mathrm{NW}$ & Mean & 5.49 & 6.33 & 1080.22 & 2.39 & 0.28 & 49.87 & 15.04 & 2.15 & 0.03 & 455.78 & 0.86 & 24.72 & 16.63 & 73.88 & 64.42 \\
\hline 115 & & SD & 0.26 & 1.02 & 213.89 & 1.74 & 0.03 & 2.55 & 2.47 & 0.05 & 0.00 & 142.27 & 0.05 & 1.85 & 0.50 & 7.81 & 7.27 \\
\hline 116 & $100 \mathrm{NW}$ & & 5.24 & 6.4 & 1180 & 0.97 & 0.20 & 43.70 & 15.6 & 2.34 & 0.048 & 956 & 0.8 & 23.0 & 21.0 & 61.0 & 69.3 \\
\hline 117 & $100 \mathrm{NW}$ & & 5.43 & 7.7 & 1420 & 1.04 & 0.29 & 48.50 & 14.0 & 2.21 & 0.040 & 704 & 0.7 & 27.0 & 17.4 & 68.8 & 62.5 \\
\hline 118 & $100 \mathrm{NW}$ & & 5.33 & 4.6 & 1290 & 1.24 & 0.92 & 41.80 & 10.9 & 1.90 & 0.045 & 588 & 0.5 & 21.2 & 15.1 & 54.0 & 53.5 \\
\hline 119 & $100 \mathrm{NW}$ & Mean & 5.33 & 6.23 & 1296.67 & 1.08 & 0.47 & 44.67 & 13.50 & 2.15 & 0.04 & 749.33 & 0.67 & 23.73 & 17.83 & 61.27 & 61.77 \\
\hline 120 & & SD & 0.10 & 1.56 & 120.14 & 0.14 & 0.39 & 3.45 & 2.39 & 0.23 & 0.00 & 188.14 & 0.15 & 2.97 & 2.97 & 7.40 & 7.93 \\
\hline 121 & $500 \mathrm{NE}$ & & 5.47 & 4.7 & 1050 & 0.96 & 0.10 & 47.00 & 14.7 & 2.32 & 0.037 & 549 & 0.8 & 22.6 & 20.8 & 75.1 & 73.8 \\
\hline 122 & $300 \mathrm{NE}$ & & 5.52 & 3.9 & 615 & 0.93 & 0.17 & 44.70 & 16.3 & 2.30 & 0.038 & 470 & 1.0 & 21.6 & 13.3 & 68.5 & 70.8 \\
\hline 123 & $100 \mathrm{NE}$ & & 5.70 & 4.6 & 278 & 0.91 & 0.23 & 50.30 & 17.2 & 2.44 & 0.043 & 380 & 1.1 & 21.7 & 14.2 & 75.2 & 77.2 \\
\hline
\end{tabular}


APPENDIX B

CHARACTERIZATION OF CONTINUING OPEN BAY DISCHARGES 
Table B-1. Open Bay Discharge Permits Identified by LDEQ (ordered alphabetically by operator, permits may be for more than one discharge, permits in bold removed from further consideration).

\begin{tabular}{|c|c|c|c|}
\hline Permit Number & Company & Field & Comment $^{1}$ \\
\hline 2901 & Aviva & Breton Sound 31 & $\mathrm{I}, \mathrm{C}$ \\
\hline 2134 & Callon Offshore Pet. & Chandeleur Sound 25 & I, C \\
\hline 1934 & \begin{tabular}{|l} 
Callon Offshore Pet \\
\end{tabular} & Main Pass 35 & $\mathrm{C}$ \\
\hline & & & \\
\hline 2860 & Callon Offshore Pet. & Black Bay & $1, C$ \\
\hline 2859 & \begin{tabular}{|l} 
Callon Offshore Pet \\
\end{tabular} & Fast Black Bay & 18 \\
\hline & & & \\
\hline 2142 & Callon Offshore Pet. & North Black Bay & $1, C$ \\
\hline & & Couthont Dlant Pan & \\
\hline 2672 & Callon Offshore Pet. & Southeast Black Bay & I, C \\
\hline 1901 & Callon Offshore Pet. & West Black Bay & $1, C$ \\
\hline 3023 & Clovelly (LL\&E) & Chandeleur Sound 51 & I, C \\
\hline 2952 & Columbia Materials & 0 & \\
\hline & & Breton Sound 20 & $1, \mathrm{C}$ \\
\hline 4206 & Devon & Breton Sound 30 & $\mathrm{NI}$ \\
\hline & & & \\
\hline 3014 & Energy Dev. Corp. & Main Pass 49 & I, C \\
\hline 2827 & Energy Dev. Corp. & Breton Sound 1 & I.C? \\
\hline & & & \\
\hline 2747 & Exxon & Lake Raccourci & $\mathrm{I}, \mathrm{N}$ \\
\hline 2732 & Exxon & Lake Sand & $\mathrm{I}, \mathrm{N}$ \\
\hline & & & \\
\hline 3320 & Greenhill Petroleum & Timbalier Bay & $\mathrm{I}, \mathrm{C}$ \\
\hline 2072 & Gulfiand (Grasso) & Main Pass 35 & LC \\
\hline & & & \\
\hline 2995 & Hubco Exploration & Saturday Island & I, C \\
\hline 3002 & \begin{tabular}{|l} 
Hubco Exploration \\
\end{tabular} & SE Saturday Island & I.C \\
\hline & & & \\
\hline 2704 & \begin{tabular}{|l|} 
Hunt Petroleum \\
\end{tabular} & Caillou Island & I,C \\
\hline & & & \\
\hline 2809 & Kerr-McGee & Breton Sound 36 & $\mathrm{I}, \mathrm{N}$ \\
\hline 2810 & Kerr-McGee & Breton Sound 32 & I, C \\
\hline & & & \\
\hline 2618 & Kerr-McGee & Breton Sound 20 & I, C \\
\hline & & & \\
\hline
\end{tabular}




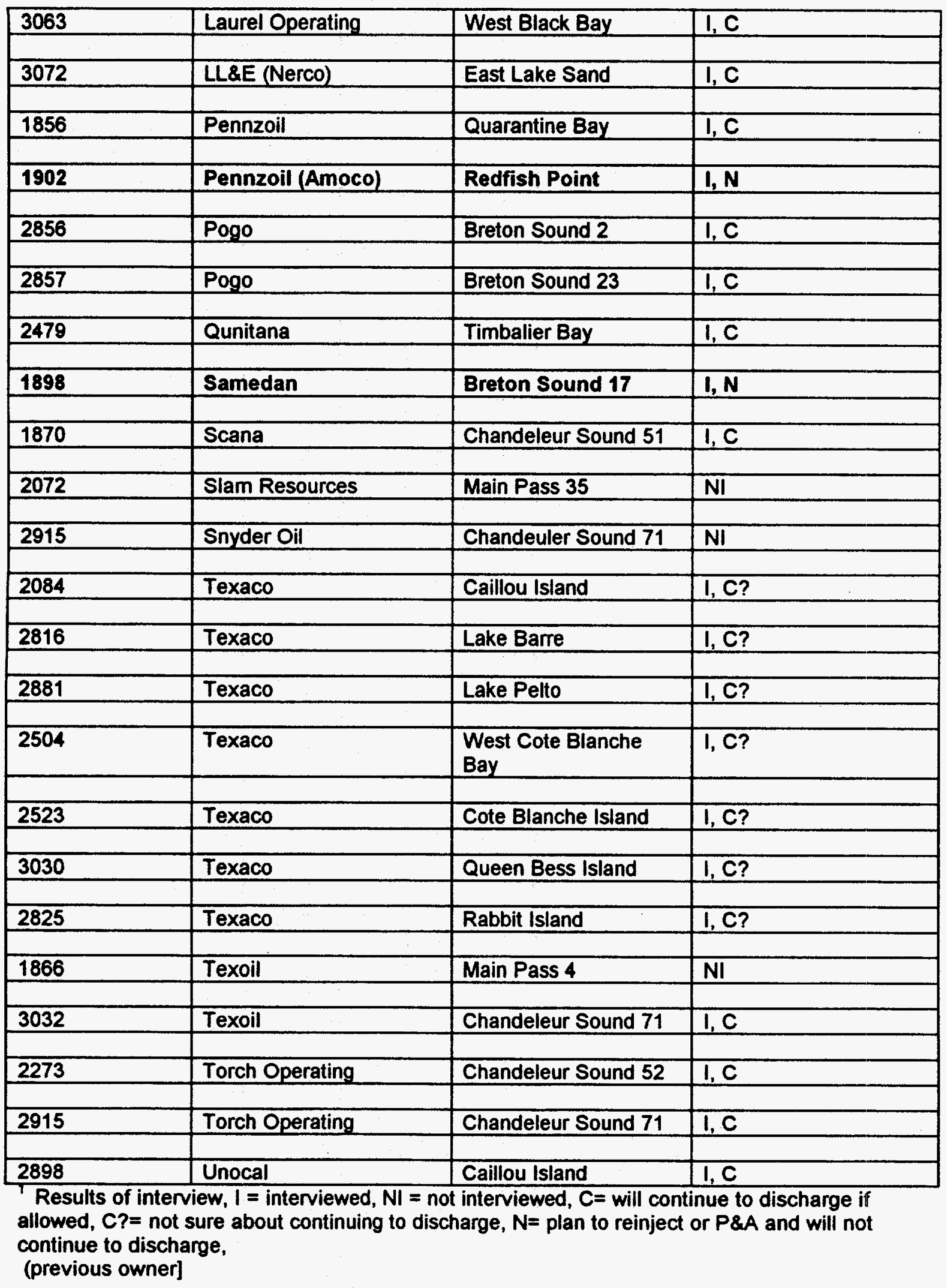


Table B-2. Location, receiving water body, depth, discharge rates and other data available for assumed continuing open bay discharges in Louisiana (ordered by receiving water body).

\begin{tabular}{|c|c|c|c|c|c|c|c|}
\hline $\begin{array}{l}\text { Permit } \\
\text { No. }\end{array}$ & Latitude & Longitude & $\begin{array}{l}\text { Receiving } \\
\text { Water Body }\end{array}$ & $\begin{array}{c}\text { Average } \\
\text { Depth } \\
\text { (ft) }\end{array}$ & $\begin{array}{c}\text { Discharge } \\
\text { Rate } \\
\text { (bbl/day) }\end{array}$ & Data $^{\top}$ & Comments \\
\hline & & & & & & & \\
\hline 2825 & $2926^{\prime} 53^{\prime \prime}$ & $9136^{\prime} 12^{\prime \prime}$ & $\begin{array}{l}\text { Atchafalaya } \\
\text { Bay }\end{array}$ & & 2,910 & $T \times N$ & \\
\hline 3002 & $2924^{\prime} 35.061$ & $8954^{\prime} 21.470^{\prime \prime}$ & Barataria Bay & 8 & 2,017 & $x C x$ & \\
\hline 1901 & $2935^{\prime} 51^{\prime \prime}$ & $8932^{\prime} 25^{n}$ & Black Bay & 7 & 10,123 & TCN & \\
\hline 1901 & $2935^{\prime} 12^{\prime \prime}$ & $8932^{\prime} 13^{\prime \prime}$ & Black Bay & 7 & 20,077 & TCN & \\
\hline 1901 & $2935^{\prime} 40^{\prime \prime}$ & $8934^{\prime} 10^{\prime \prime}$ & Black Bay & 8 & 11,500 & TCN & \\
\hline 2672 & $2932^{\prime} 48.918^{\prime \prime}$ & $8929^{\prime} 10.609^{\prime \prime}$ & Black Bay & 7 & 8,366 & $T \times N$ & \\
\hline 2860 & $2934^{\prime} 9.7^{\prime \prime}$ & $8930^{\prime} 45^{n}$ & Black Bay & & 6,800 & $T C N$ & \\
\hline 3063 & $2935^{\prime} 40^{\prime \prime}$ & $8934^{\prime} 10$ & Black Bay & 8 & 11,500 & $T \times x$ & \\
\hline 2072 & $2927^{\prime} 3.403^{\prime \prime}$ & $8924^{\prime} 11.464$ & Breton Sound & 8 & 17,500 & $x C N$ & \\
\hline 2618 & $2934^{\prime} 41.4^{\prime \prime}$ & $8907^{\prime} 00^{\prime \prime}$ & Breton Sound & & 22,500 & $x \times N$ & \\
\hline 2856 & & & Breton Sound & & 3 & TCX & \\
\hline 2857 & $2935^{\prime} 31.251^{\prime \prime}$ & $8901^{\prime} 53.993^{\prime \prime}$ & Breton Sound & & 10 & $\mathrm{~T} \times \mathrm{x}$ & \\
\hline 2857 & $2935^{\prime} 6.121^{\prime \prime}$ & $8900^{\prime} 4.795^{\prime \prime}$ & Breton Sound & & 10 & $\mathrm{~T} \times \mathrm{x}$ & \\
\hline 2901 & & & Breton Sound & & 200 & $x \times x$ & $\begin{array}{l}\text { Permit not } \\
\text { Available }\end{array}$ \\
\hline 2901 & & & Breton Sound & & 876 & $x \times x$ & $\begin{array}{l}\text { Permit Not } \\
\text { Available }\end{array}$ \\
\hline 2952 & $2937^{\prime} 4.813^{n}$ & $894^{\prime} 12.891^{\prime \prime}$ & Breton Sound & 18 & 223 & $x \times N$ & \\
\hline 1870 & $2946^{\prime} 32^{\prime \prime}$ & $8915^{\prime} 09^{\prime \prime}$ & $\begin{array}{l}\text { Chandeleur } \\
\text { Sound }\end{array}$ & & 49 & TCN & \\
\hline 2273 & $2945^{\prime} 08.65^{\prime \prime}$ & $8912^{\prime} 29.31^{\prime \prime}$ & $\begin{array}{l}\text { Chandeleur } \\
\text { Sound }\end{array}$ & & & $x \subset x$ & \\
\hline 2915 & $2942^{\prime} 16^{\prime \prime}$ & $8924^{\prime} 23^{\prime \prime}$ & $\begin{array}{l}\text { Chandeleur } \\
\text { Sound }\end{array}$ & 6 & 130 & TCN & \\
\hline 3023 & $2946^{\prime} 21^{\prime \prime}$ & $8916^{\prime} 52^{\prime \prime}$ & $\begin{array}{l}\text { Chandeleur } \\
\text { sound }\end{array}$ & 10 & 3.4 & TCX & \\
\hline 3032 & $2942^{\prime} 15.824^{\prime \prime}$ & $8924^{\prime} 23.062^{\prime \prime}$ & $\begin{array}{l}\text { Chandeleur } \\
\text { sound }\end{array}$ & 10 & 25 & TCN & \\
\hline 3032 & $2941^{\prime} 46.466^{\prime \prime}$ & $8923^{\prime} 48.018^{\prime \prime}$ & $\begin{array}{l}\text { Chandeleur } \\
\text { sound }\end{array}$ & 10 & 25 & TCN & \\
\hline 2859 & $2933^{\prime} 45.179^{\prime \prime}$ & $8926^{\prime} 27.147^{\prime \prime}$ & E. Black Bay & & 10,807 & TCX & \\
\hline 2816 & $2912^{\prime} 50^{\prime \prime}$ & $9029^{\prime \prime} 20^{n}$ & Jacko Bay & & 600 & $T \times x$ & \\
\hline 2816 & $2912^{\prime} 10^{\prime \prime}$ & $9028^{\prime} 10^{n}$ & Jacko Bay & & 220 & $T \times x$ & \\
\hline 2816 & $2912^{\prime} 50^{\prime \prime}$ & $9028^{\prime} 00^{\prime \prime}$ & Jacko Bay & & 614 & $T \times x$ & \\
\hline 2816 & $2912^{\prime} 00^{\prime \prime}$ & $9028^{\prime} 50^{\prime \prime}$ & Jacko Bay & & 117 & $T \times x$ & \\
\hline 2816 & $2913^{n} 00^{n}$ & $9030^{\prime \prime} 50^{\prime \prime}$ & Jacko Bay & & int. & $T \times x$ & \\
\hline 2816 & $2919^{\prime} 50^{\prime \prime}$ & $9030^{\prime} 10^{n}$ & Jacko Bay & & 30 & $T \times x$ & \\
\hline 2816 & $2912^{\prime} 00^{\prime \prime}$ & $9029^{\prime} 50^{\prime \prime}$ & Jacko Bay & & int & $T \times x$ & \\
\hline 2816 & $2913^{\prime} 00^{\prime \prime}$ & $90-28^{\prime} 40^{\prime \prime}$ & Lake Barre & & 510 & $T \times x$ & \\
\hline 2881 & $2906^{\prime} 20^{\prime \prime}$ & $9039^{\prime} 10^{\prime \prime}$ & Lake Pelto & & 729 & $T \times x$ & \\
\hline 2881 & $2905^{\prime} 20^{\prime \prime}$ & $9038^{\prime} 30^{n}$ & Lake Pelto & & 1,103 & $T \times x$ & \\
\hline
\end{tabular}




\begin{tabular}{|c|c|c|c|c|c|c|c|}
\hline 2881 & $2906^{\prime} 10^{\prime \prime}$ & $9038^{\prime} 40^{\prime \prime}$ & Lake Pelto & & 489 & $T \times x$ & \\
\hline 2881 & $2905^{\prime} 00^{\prime \prime}$ & $9039^{\prime} 50^{\prime \prime}$ & Lake Pelto & & 2,485 & $T \times x$ & \\
\hline 1866 & $29-41^{\prime} 31.2^{\prime \prime}$ & $89-22^{\prime} 0.2^{\prime \prime}$ & Main Pass & & & $T \times N$ & \\
\hline 2072 & & & Main Pass & & 20,250 & $x C N$ & \\
\hline 2134 & $2946^{\prime} 26^{\prime \prime}$ & $8917^{\prime} 27^{\prime \prime}$ & Main Pass & & & $x \times x$ & $\begin{array}{l}\text { Permit not } \\
\text { available }\end{array}$ \\
\hline 2134 & $2949^{\prime} 35^{\prime \prime}$ & $8919^{\prime} 58^{\prime \prime}$ & Main Pass & & & $x \times x$ & $\begin{array}{l}\text { Permit not } \\
\text { available }\end{array}$ \\
\hline 3014 & & & Main Pass & & $\overline{0}$ & $x \times x$ & $\begin{array}{l}\text { Permit not } \\
\text { available }\end{array}$ \\
\hline 2142 & $2938^{\prime} 12.03^{\prime \prime}$ & $8933^{\prime} 33.64^{\prime \prime}$ & $\begin{array}{l}\text { North Black } \\
\text { Bay }\end{array}$ & & 12,076 & TCN & \\
\hline 1856 & $2925^{\prime} 09^{\prime \prime}$ & $8930^{\prime} 49^{\prime \prime}$ & $\begin{array}{l}\text { Quarantine } \\
\text { Bay }\end{array}$ & 10 & 15,000 & TCX & \\
\hline 2995 & $2910^{\prime} 43.943^{\prime \prime}$ & $9046^{\prime} 30.170^{\prime \prime}$ & Salt Bay & 8 & & $x \times x$ & \\
\hline 2881 & $2905^{\prime} 20^{\prime \prime}$ & $9040^{\prime} 50^{\prime \prime}$ & $\begin{array}{l}\text { Terrebonne } \\
\text { Bay }\end{array}$ & & 204 & $T \times N$ & \\
\hline 2084 & $2906^{\prime} 50^{\prime \prime}$ & $9029^{\prime} 00^{\prime \prime}$ & $\begin{array}{l}\text { Terrebonne } \\
\text { Bay }\end{array}$ & 10 & 2,484 & $T \times N$ & \\
\hline 2084 & $2905^{\circ} 30^{\prime \prime}$ & $9030^{\prime} 40^{\prime \prime}$ & $\begin{array}{l}\text { Terrebonne } \\
\text { Bay }\end{array}$ & 10 & 3,017 & $T \times N$ & \\
\hline 2084 & $290710^{n}$ & $9030^{\prime} 10^{\prime \prime}$ & $\begin{array}{l}\text { Terrebonne } \\
\text { Bay }\end{array}$ & 10 & 3,720 & $T \times N$ & \\
\hline 2084 & $2907^{\prime} 20^{\prime \prime}$ & $2931^{\prime} 10^{n}$ & $\begin{array}{l}\text { Terrebonne } \\
\text { Bay }\end{array}$ & & & $T \times N$ & \\
\hline 2084 & $2906^{\circ} 00^{\prime \prime}$ & $9025^{\prime} 50^{\prime \prime}$ & $\begin{array}{l}\text { Terrebonne } \\
\text { Bay }\end{array}$ & 10 & 41 & $T \times N$ & \\
\hline 2084 & $2904^{\prime} 00^{\prime \prime}$ & $9028^{\prime} 40^{\prime \prime}$ & $\begin{array}{l}\text { Terrebonne } \\
\text { Bay }\end{array}$ & 10 & 701 & $T \times N$ & \\
\hline 2704 & $2905^{\prime} 28.293$ & $9032^{\prime} 17.027^{\prime \prime}$ & $\begin{array}{l}\text { Terrebonne } \\
\text { Bay }\end{array}$ & 8 & 524 & $x \times N$ & \\
\hline 2816 & $2911^{\prime} 20^{\prime \prime}$ & $9029^{\prime} 00^{\prime \prime}$ & $\begin{array}{l}\text { Terrebonne } \\
\text { Bay }\end{array}$ & & 30 & $T \times x$ & \\
\hline 2816 & $2922^{\prime} 30^{\prime \prime}$ & $9030^{\prime} 50^{\prime \prime}$ & $\begin{array}{l}\text { Terrebonne } \\
\text { Bay }\end{array}$ & & 140 & $T \times x$ & \\
\hline 2898 & $2904^{\prime} 25^{\prime \prime}$ & $9024^{\prime} 20^{\prime \prime}$ & $\begin{array}{l}\text { Terrebonne } \\
\text { Bay }\end{array}$ & 4 & 3,000 & TCN & \\
\hline 2898 & $2907^{\prime} 50^{\prime \prime}$ & $9029^{\prime} 50^{\prime \prime}$ & $\begin{array}{l}\text { Terrebonne } \\
\text { Bay }\end{array}$ & & & TCN & \\
\hline 2898 & $2906^{\prime} 00^{\prime \prime}$ & $9028^{\prime} 40^{\prime \prime}$ & $\begin{array}{l}\text { Terrebonne } \\
\text { Bay }\end{array}$ & 10 & 617 & TCN & \\
\hline 2479 & & & Timbailier Bay & & 10 & TCN & \\
\hline 2816 & $2912^{\prime} 00^{\prime \prime}$ & $9026^{\prime \prime} 50^{\prime \prime}$ & Timbailier Bay & & 10 & $T \times x$ & \\
\hline 2898 & $2904^{n} 20^{n}$ & $9025^{\prime} 30^{\prime \prime}$ & Timbailier Bay & & & $T C N$ & \\
\hline 3320 & $2905^{\prime} 29^{\prime \prime}$ & $9018^{\prime} 30^{\prime \prime}$ & Timbailier Bay & & 4,744 & $x \times N$ & \\
\hline 3320 & $2904^{\prime} 12^{n}$ & $9018^{\prime} 30^{\prime \prime}$ & Timbailier Bay & & 3,873 & TCN & \\
\hline 3320 & $2904^{\prime} 33^{\prime \prime}$ & $9017^{\prime} 10^{\prime \prime}$ & Timbailier Bay & & 4,914 & $x \times N$ & \\
\hline 3320 & $2904^{\prime} 37^{\prime}$ & $9019^{\prime} 2^{n}$ & Timbailier Bay & & 7,368 & $x \times N$ & \\
\hline 3320 & $2904^{\prime} 17^{\prime}$ & $9019^{\prime} 25^{\prime \prime}$ & Timbailier Bay & & 1,680 & $x \times N$ & \\
\hline 2084 & $2906^{\prime} 20^{\prime \prime}$ & $9027^{\prime} 30^{\prime \prime}$ & Timbalier Bay & 10 & 1,201 & $T \times N$ & \\
\hline 2084 & $2907^{\prime} 00^{\prime \prime}$ & $9026^{\prime} 40^{n}$ & Timbalier Bay & & & $T \times N$ & \\
\hline 2084 & $2906^{\prime} 10^{\prime \prime}$ & $902650^{\prime \prime}$ & Timbalier Bay & & & $T \times N$ & \\
\hline
\end{tabular}




\begin{tabular}{|c|c|c|c|c|c|c|c|}
\hline 2084 & $2905^{\prime} 20^{\prime \prime}$ & $9027^{\prime} 00^{n}$ & Timbalier Bay & & & $T \times N$ & \\
\hline 2084 & $2905^{\prime} 22^{\prime \prime}$ & $9025^{\prime} 56^{\prime \prime}$ & Timbalier Bay & & & $T \times N$ & \\
\hline 2084 & $2907^{\prime} 00^{\prime \prime}$ & $9032^{\prime} 40^{n}$ & Timbalier Bay & 10 & 802 & $T \times N$ & \\
\hline 2084 & $2905^{\prime} 20^{\prime \prime}$ & $9027^{\prime} 00^{n}$ & Timbalier Bay & 10 & 2,126 & $T \times N$ & \\
\hline 2084 & $2908^{\prime} 00^{\prime \prime}$ & $9027^{\prime} 40^{n}$ & Timbalier Bay & 10 & 2,065 & $T \times N$ & \\
\hline 2084 & $2906^{\prime} 50^{n}$ & $9027^{\prime} 50^{n}$ & Timbalier Bay & 10 & 586 & $T \times N$ & \\
\hline 2084 & $2906^{\prime} 19^{n}$ & $9027^{\prime} 58^{\prime \prime}$ & Timbalier Bay & & & $T \times N$ & \\
\hline 2504 & $2941^{\prime} 04^{\prime \prime}$ & $9147^{\prime} 59^{\prime \prime}$ & $\begin{array}{l}\text { West Cote } \\
\text { Blance Bay }\end{array}$ & 10 & 37,113 & $T \times N$ & \\
\hline 2523 & $2943^{\prime} 10^{\prime \prime}$ & $9142^{\prime} 00^{\prime \prime}$ & $\begin{array}{l}\text { West Cote } \\
\text { Blanche Bay }\end{array}$ & 7 & 5,364 & TCN & \\
\hline 2523 & $2943^{\prime} 48^{\prime \prime}$ & $9141^{\prime} 35^{\prime \prime}$ & $\begin{array}{l}\text { West Cote } \\
\text { Blanche Bay }\end{array}$ & & & TCN & \\
\hline 1934 & & & & & 14,443 & $x \times x$ & $\begin{array}{l}\text { Permit not } \\
\text { available }\end{array}$ \\
\hline 2827 & & & & & 1 & $\times x \times$ & \\
\hline 2915 & & & & & & $\times \times x$ & $\begin{array}{l}\text { Permit not } \\
\text { available }\end{array}$ \\
\hline 3072 & & & & & & $x \times x$ & $\begin{array}{l}\text { No Data in } \\
\text { Permit File }\end{array}$ \\
\hline 4206 & & & & & & $x \times x$ & $\begin{array}{l}\text { Permit Not } \\
\text { Available }\end{array}$ \\
\hline
\end{tabular}

'Available Data" $T=$ toxicity data; $C=$ chemical data; $N=$ NORM data 
Figure C-1. Assumed active discharges in open Louisiana bays.
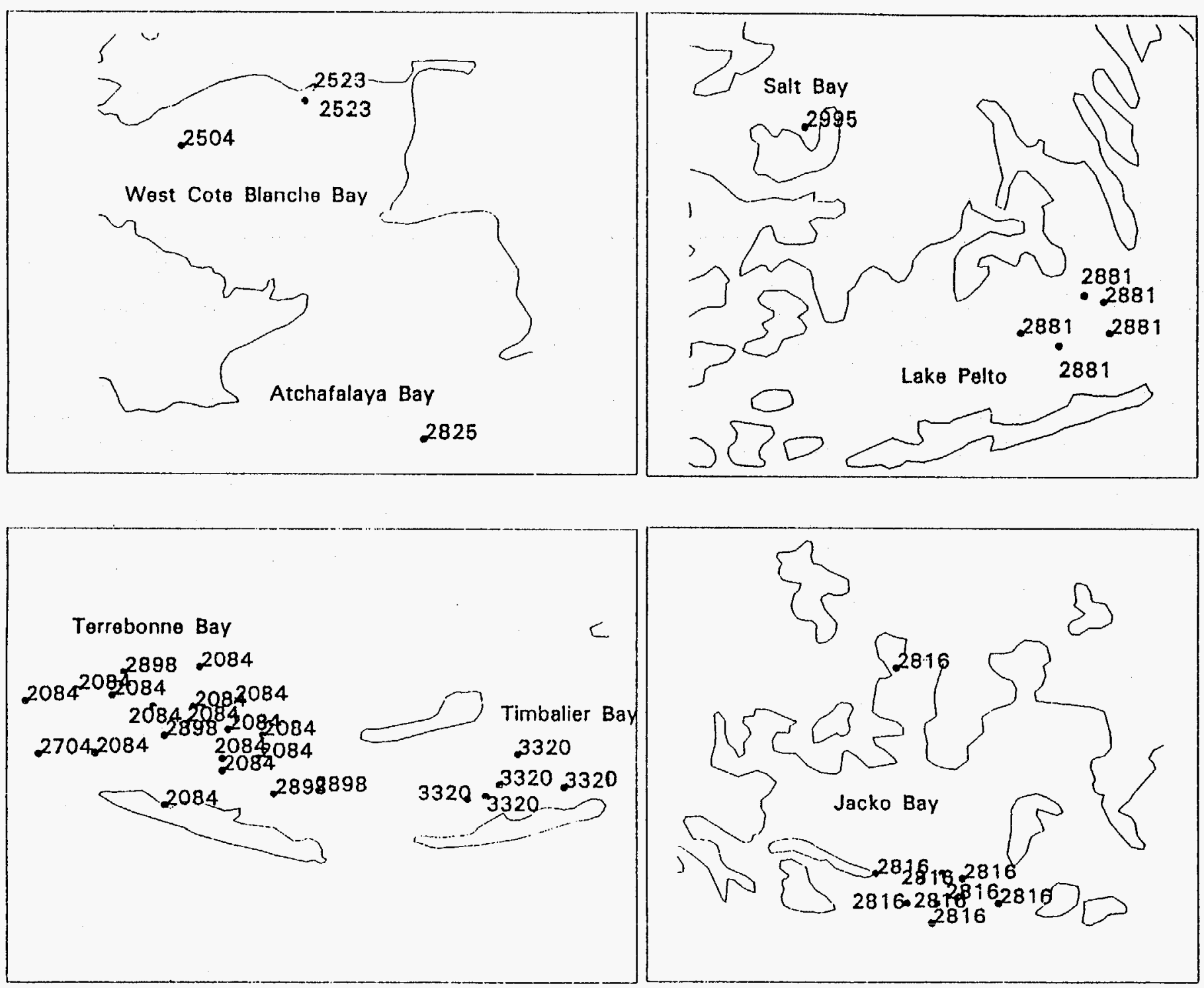


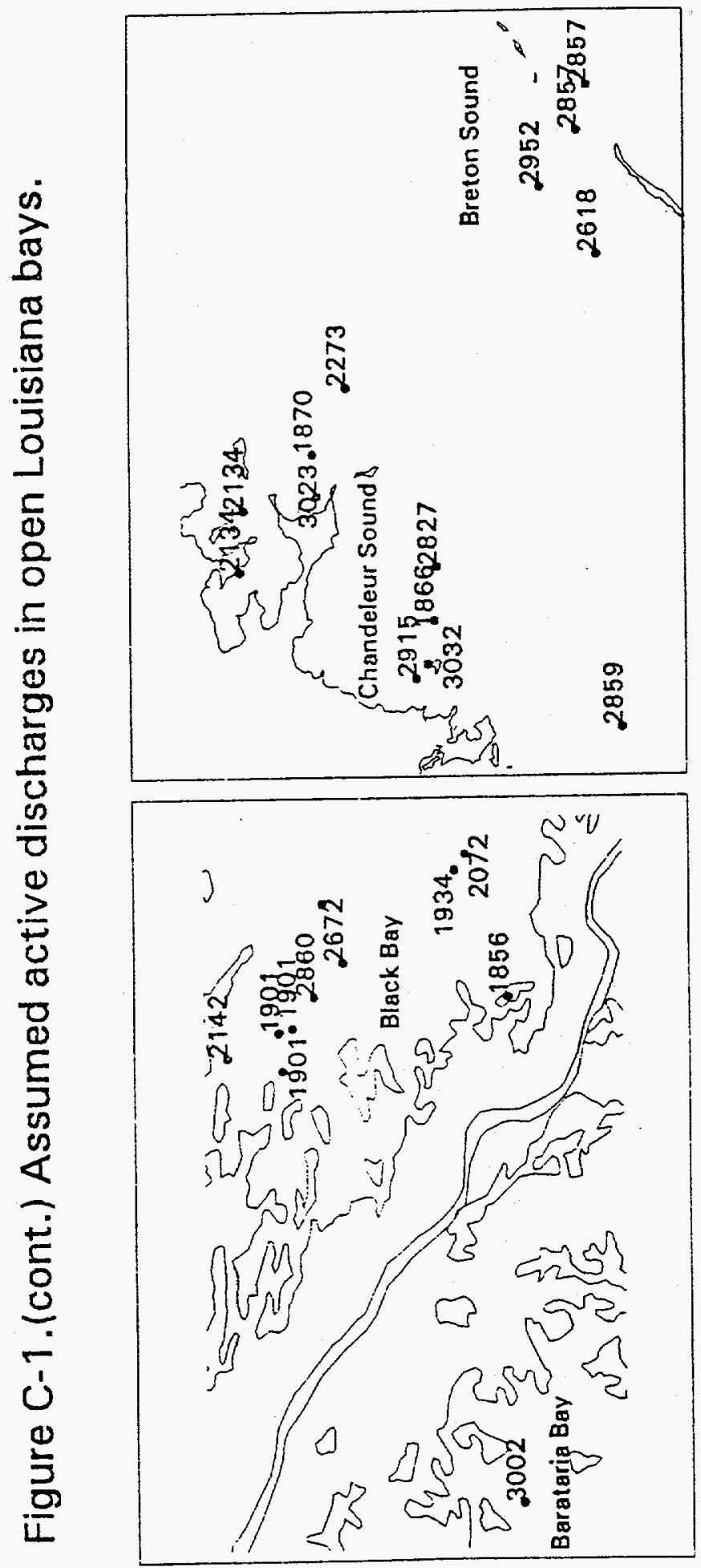




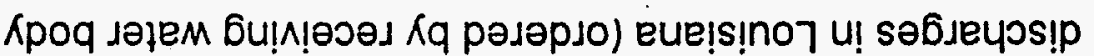

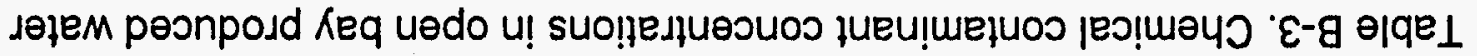

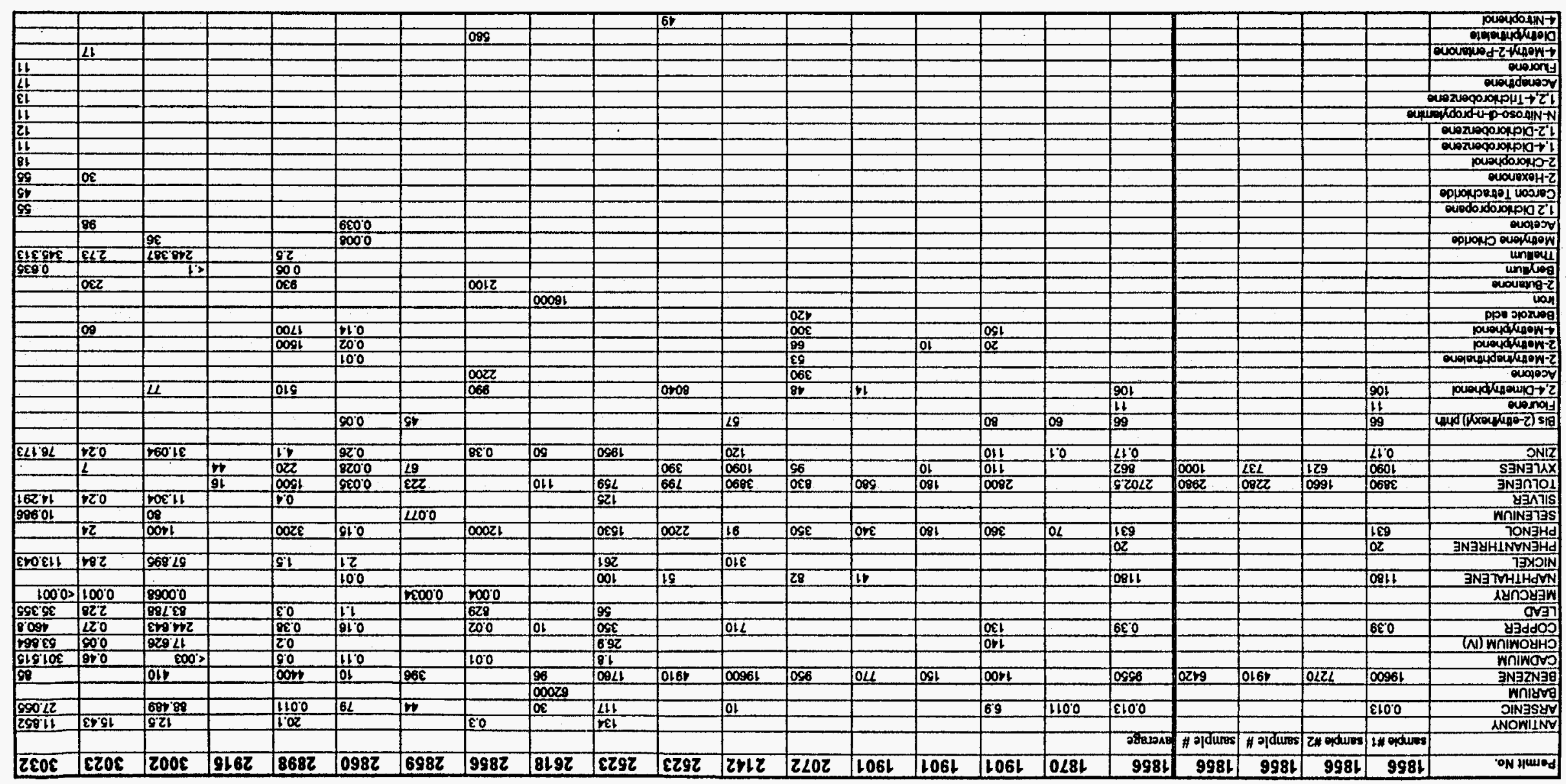


Table B-4. Radium concentrations in open bay produced water discharges in Louisiana (ordered by receiving water body).

\begin{tabular}{|l|l|l|l|}
\hline Permit No. & & $\begin{array}{l}\text { 23 Ra } \\
\text { (pCi/l) }\end{array}$ & $\begin{array}{l}\text { Ra } \\
\text { (pCi/l) }\end{array}$ \\
\hline 1866 & & 23 & 2 \\
\hline 1870 & & 73.8 & 109.0 \\
\hline 1901 & & 296 & 367 \\
\hline 1902 & & 178 & 245 \\
\hline 2072 & & 240 & 273 \\
\hline 2084 & Tank Bat 2 & 181 & 282 \\
\hline 2084 & Tank Bat 4 & 65.2 & 69.2 \\
\hline 2084 & Tank Bat 6 & 308 & 368 \\
\hline 2084 & Tank Bat 7 & 87.1 & 61.4 \\
\hline 2084 & Tank Bat 8 & 156 & 91.4 \\
\hline 2084 & Tank Bat 9 & 273 & 424 \\
\hline 2084 & Tank Bat 10 & 172 & 295 \\
\hline 2084 & Tank Bat 11 & 114 & 171 \\
\hline 2084 & Tank Bat 14 & 117 & 208 \\
\hline 2084 & Tank Bat 15 & 247 & 291 \\
\hline 2084 & Tank Bat 17 & 146 & 283 \\
\hline 2084 & Tank Bat 18 & 50.2 & 56.3 \\
\hline 2084 & Tank Bat 19 & 272 & 353 \\
\hline 2084 & Tank Bat 20 & 380 & 558 \\
\hline 2084 & Tank Bat 21 & 311 & 483 \\
\hline 2084 & Tank Bat 22 & 89.2 & 125 \\
\hline 2084 & Tank Bat 23 & 68 & 47.1 \\
\hline 2084 & Tank Bat 24 & 131 & 225.0 \\
\hline 2142 & & 277.0 & 341.0 \\
\hline 2479 & & 3.9 & 2 \\
\hline 2504 & & 108 & 149 \\
\hline 2523 & TB\#3 & 207 & 326 \\
\hline 2523 & TB\#1 & 129 & 206 \\
\hline 2618 & & 201 & 289 \\
\hline 2672 & & 277.0 & 341.01 \\
\hline 2704 & & 127 & 400 \\
\hline
\end{tabular}




\begin{tabular}{|l|l|l|l|}
\hline 2825 & & 436 & 501 \\
\hline 2860 & & 120 & 41.9 \\
\hline 2881 & TB\#2 & 52.7 & 109 \\
\hline 2881 & TB\#3 & 194.0 & 307 \\
\hline 2881 & TB\#4 & 173 & 472 \\
\hline 2881 & TB\#5 & 290 & 545.0 \\
\hline 2881 & TB\#1 & 224 & 389 \\
\hline 2898 & & 0.0 & 0 \\
\hline 2915 & & 290 & 60 \\
\hline 2915 & & 34 & 66 \\
\hline 2952 & & 52 & 15 \\
\hline 3032 & & 592 & 188 \\
\hline 3320 & & 198 & 265 \\
\hline 3320 & & 290 & 272 \\
\hline 3320 & & 284 & 402 \\
\hline 3320 & & 303 & 361 \\
\hline 3320 & & 333 & 560 \\
\hline
\end{tabular}




\section{APPENDIX C \\ RADIONUCLIDE EFFECTS}

\section{C.1 Quantities and Units}

Traditional units in radiation dose measurements (i.e. $\mathrm{Ci}$, rad, rem) are being replaced by the International System (SI) of units (Bq, Gy, Sv). The names and units (traditional and $\mathrm{SI}$ ) for activity, absorbed dose and dose equivalent are given in Table C-1. Prefixes commonly applied to these units are given in Table C-2.

Table C-1. Radiological names and units.

\begin{tabular}{|l|l|l|l|l|l|}
\hline Quantity & \multicolumn{2}{|c|}{ Traditional } & \multicolumn{2}{c|}{ SI } & Conversion \\
\hline & Name & Unit & Name & Unit & \\
\hline & & & & & \\
\hline activity & curie (Ci) & $\begin{array}{l}3.7 \times 10^{10} \\
\text { dis/sec }\end{array}$ & becquerel (Bq) & 1 dis/sec & $\begin{array}{l}1 \mathrm{~Bq}= \\
2.7 \times 10^{-11} \mathrm{Ci}\end{array}$ \\
\hline $\begin{array}{l}\text { absorbed } \\
\text { dose }\end{array}$ & rad (rad) & $100 \mathrm{erg} / \mathrm{gm}$ & gray (Gy) & $1 \mathrm{~J} / \mathrm{kg}$ & $1 \mathrm{~Gy}=100 \mathrm{rad}$ \\
\hline $\begin{array}{l}\text { equivalent } \\
\text { dose }\end{array}$ & rem (rem) & $100 \mathrm{erg} / \mathrm{gm}$ & sievert (Sv) & $1 \mathrm{~J} / \mathrm{kg}$ & $1 \mathrm{~Sv}=100 \mathrm{rem}$ \\
\hline
\end{tabular}

Table C-2. Prefixes used in radiation protection.

\begin{tabular}{|l|l|}
\hline pico $(\mathrm{p})$ & $10^{-12}$ \\
\hline nano $(\mathrm{n})$ & $10^{-8}$ \\
\hline micro $(\mu)$ & $10^{-6}$ \\
\hline milli $(\mathrm{m})$ & $10^{-3}$ \\
\hline kilo $(\mathrm{k})$ & $10^{3}$ \\
\hline mega $(\mathrm{M})$ & $10^{6}$ \\
\hline giga $(\mathrm{G})$ & $10^{9}$ \\
\hline tera $(\mathrm{T})$ & $10^{12}$ \\
\hline
\end{tabular}

Radioactivity is quantified in terms of the number of spontaneous energy emitting transformations per unit time -- a quantity known as activity. An example of a transformation is the decay of a radium 226 nucleus into a radon 222 nucleus, an alpha particle and gamma rays. The unit of activity has historically been the curie $(\mathrm{Ci})$. One curie is equal to $3.7 \times 10^{10}$ disintegrations per second. In the SI system, the basic unit of activity has been redefined as one disintegration per second, known as the becquerel $(\mathrm{Bq})$. One curie is equal to $3.7 \times 10^{10} \mathrm{~Bq}$. 
The biological effects of exposure to a radionuclide are related to the absorbed dose and dose rate. The absorbed dose is a measure of the energy imparted to matter. An absorbed dose of $100 \mathrm{erg} / \mathrm{gram}$ is called $1 \mathrm{rad}$. In the SI system of units, the unit of absorbed dose is the Gray (Gy, 1 Joule/kilogram). An absorbed dose of $1 \mathrm{rad}$ is equal to $0.01 \mathrm{~Gy}(1 \mathrm{~Gy}=100 \mathrm{rads})$.

The probability of stochastic effects (i.e. cancer and genetic effects) depends not only on the absorbed dose, but also on the type and energy of the radiation causing the dose and on the organs or tissues irradiated. Factors have been developed by the International Commission on Radiological Protection (ICRP, 1991) to account for these relationships in humans.

Radiation weighting factors are used to account for the differences in relative biological effectiveness (RBE) of different radiations. In the past these differences were accounted for by use of quality factors. The radiation weighting factor for gamma radiation $(\gamma)$ and beta $(\beta)$ particles has been assigned a value of 1 . The weighting factor for alpha $(\alpha)$ particles is set to 20 . The absorbed dose modified by the weighting factor is called the equivalent dose and is expressed in units of Joules per kilogram with the name Sievert (Sv) given to 1 Joule/kg. The traditional unit is the rem (see Table C-1). One Sievert is equal to 100 rem.

Tissue weighting factors are used to account for differences in the sensitivity to cancer induction of different human tissues and organs. A tissue weighting factor represents the relative contribution of that organ or tissue to the total effects resulting from uniform irradiation of the whole body. These factors are given in ICRP (1991). The equivalent dose weighted by these tissue weighting factors is referred to as the effective dose. For a uniform, whole body exposure, the equivalent and effective doses have the same value, and are both expressed in units of Sieverts (Sv).

The limited data for the relative biological effectiveness of various radiation types in man indicate that the RBE can be expected to be similar for aquatic organisms, (Woodhead, 1984), because the soft tissues of man and other organisms are generally similar in terms of water content and basic cell structure (IAEA, 1988). IAEA (1988) suggested that it is reasonable to apply the same quality factors (now radiation weighting factors) derived for humans to doses received by aquatic organisms. There are no parallel tissue weighting factors for aquatic organisms, and the usual approach to estimating doses to aquatic animals to assume that the dose is averaged over the whole body of the organism. NCRP (1991) suggests this approach is reasonable, as long as the average whole body exposure is representative of the dose to the gonads. NCRP also suggests that it may be useful to estimate the dose to the most highly exposed tissue (NCRP, 1991). 


\section{C.2 Human Health Effects From Radium Ingestion}

\section{C.2.1 Carcinogenicity of Radium}

The health effects of radium can be attributed to the radioactive emissions of the radium isotopes and their daughters. The alpha, beta and gamma radiation released by the decay of radium and its daughters cause ionization of cellular components which may result in the mutation or death of affected cells.

Most of the information concerning the health effects of radium come from studies of two groups of people: radium dial painters who ingested radium paint and patients who were injected with radium-224 for treatment of spinal arthritis and tuberculosis of the bone (NAS, 1988). The primary data come from studies of radium dial painters (Rowland et al., 1978, 1983). Radium body burdens were measured in the dial painters and were used to calculate lifetime intake.

In these studies, ingestion of ${ }^{226} \mathrm{Ra}$ resulted in bone cancers (osteosarcomas) and cancers of the linings of the cranial sinuses (head carcinomas). Ingestion of ${ }^{228} \mathrm{Ra}$ resulted in bone cancers. The dose-response function for bone cancer induced by ingestion of ${ }^{226} \mathrm{Ra}$ or ${ }^{228} \mathrm{Ra}$ is purely quadratic, with no excess cancers at lower doses. From a practical point of view, the dose-response function exhibits a threshold at a dose to the skeleton that is well above the worst environmental exposures that have been documented.

The data for head carcinomas can fit either a linear or quadratic function. These carcinomas are attributed to radon-222, a daughter of ${ }^{226} \mathrm{Ra}$. No excess head carcinomas are associated with ${ }^{228} \mathrm{Ra}$. The half-life of its daughter product, radon-224, is too short to allow migration to and accumulation in cranial sinuses.

\section{C.2.2 USEPA Risk Factors for Radium}

Current practice in radiation protection is to assume there is a cancer risk associated with even small doses of radiation. Risk factors are derived from epidemiological data and extrapolated down to low doses to describe the cancer risk associated with small exposures.

The Science Advisory Board (SAB) has recommended that the USEPA use the epidemiological evidence for bone and head cancers in radium dial painters to derive risk factors for radium (SAB, 1991). The evidence for radium-induction of other soft-tissue cancers is equivocal (Stebbings et al., 1984).

USEPA derived radium risk factors using the RADRISK model, based on effective dose equivalents given in ICRP (1977), modified to account for the specific metabolic behaviors of radioactive daughters (USEPA, 1991).

RADRISK incorporates a toxicokinetic model based upon alkaline earth intake, 
retention and excretion. RADRISK is a linear, no-threshold model that uses the sum of weighted organ doses to arrive at a single dose coefficient used to predict either the risk of getting a cancer or the risk of dying from cancer. RADRISK incorporates a life-table analysis to adjust for age- and sex specific mortality from competing risks.

RADRISK uses a gut uptake factor $\left(f_{1}\right)$ of 0.2 , the value recommended by the ICRP (1979). This value is based on data for adult humans who ingested radium in water or incorporated into food (ICRP, 1973; Stehney and Lucas, 1956). Weighting factors in RADRISK were modified from those of the ICRP (USEPA, 1991) to calculate the risks for all cancers (fatal and non-fatal). "Ingested radium is estimated to distribute about $85 \%$ to bone and $15 \%$ to soft tissue. (UNSCEAR, 1972)" (USEPA, 1991).

The RADRISK model results were adjusted for the over-prediction of leukemias and lack of prediction of head carcinomas (Federal Register, 1991), but the RADRISK model still produces a majority (about two-thirds) of the overall risk estimate for soft tissues, where either no evidence or marginal evidence exists for radium induced cancers. For example, increases in breast cancer and multiple myelomas correlate better with duration of employment, a surrogate for external dose of gamma radiation, than with radium intake (Stebbings et al., 1984). According to the USEPA, the ratio of all cancer risks to the risks for bone and cranial cancers may be overestimated by a factor of between two and five (Federal Register, 1991).

The analysis performed by the USEPA (Federal Register, 1991; USEPA 1991) assumes a linear dose-response relationship for bone sarcoma, although the best fit for bone sarcoma in the radium dial painters is quadratic (USEPA, 1991). If the true relationship is quadratic, the USEPA risk factors will be overestimates. There may also exist a practical threshold for bone sarcoma (USEPA, 1991). Additional uncertainties and assumptions in the USEPA analysis are described in USEPA (1991).

Using RADRISK, the United States Environmental Protection Agency (USEPA) estimated the risk factor associated with the ingestion of ${ }^{226} \mathrm{Ra}$ in drinking water to be $4.4 \times 10^{-6}$ lifetime risk per $\mathrm{pCi} / \mathrm{ll}$, and the risk factor for ${ }^{228} \mathrm{Ra}$ to be $3.8 \times 10^{-6}$ lifetime risk per pCill (assuming lifetime exposure) (Federal Register, 1991; USEPA, 1991). These risk factors are based on an assumed water intake of 2 I/day. Unit risk factors (individual lifetime fatal cancer risk per $\mathrm{pCi/day)}$ can be derived from these values by dividing the risk factors by two. The USEPA risk factors are then equivalent to $2.2 \times 10^{-6}$ lifetime risk per $\mathrm{pCi} /$ day for ${ }^{226} \mathrm{Ra}$ and 1.9 $\times 10^{-6}$ lifetime risk per $\mathrm{pCi} / \mathrm{day}$ for ${ }^{228} \mathrm{Ra}$ (assuming lifetime exposure) (Table C3). 


\section{C.2.3 Risk Factor Distribution}

A risk factor distribution for ${ }^{226} \mathrm{Ra}$ and ${ }^{228} \mathrm{Ra}$ was derived by assuming that the USEPA values represent the upper $90 \%$ confidence limit of a lognormal distribution. The lower $90 \%$ confidence limit was based on the risk factors for the radium induced cancers in humans for which there is epidemiologic evidence (bone and head carcinomas for ${ }^{226} \mathrm{Ra}$ and bone sarcoma for ${ }^{228} \mathrm{Ra}$ ). The methods of Layton et al. (1987) were used to establish lognormal distributions with the arithmetic means and standard deviations given in Table C-4.

Table C-3. USEPA risk factors for ${ }^{226} \mathrm{Ra}$ and ${ }^{228} \mathrm{Ra}^{*}$.

\begin{tabular}{|c|c|c|c|c|}
\hline TYPE & \multicolumn{2}{|c|}{ USEPA RISK FACTORS } & \multicolumn{2}{|c|}{ USEPA UNIT RISK FACTORS } \\
\hline & ${ }^{226} \mathbf{R a}$ & ${ }^{228} \mathbf{R a}$ & ${ }^{226} \mathbf{R a}$ & ${ }^{223} \mathbf{R a}$ \\
\hline & risk per $\mathrm{pCi} / \mathrm{l}$ & risk per $\mathrm{pCi} / \mathrm{l}$ & risk per $\mathrm{pCi} / \mathrm{d}$ & risk per $\mathrm{pCi} / \mathrm{d}$ \\
\hline Bone Sarcoma & $9.4 \times 10^{-1}$ & $9.4 \times 10^{-1}$ & $4.7 \times 10^{-1}$ & $4.7 \times 10^{-1}$ \\
\hline Head Carcinoma & $9.4 \times 10^{-1}$ & 0 & $4.7 \times 10^{-7}$ & D \\
\hline Leukemia, high LET & $2.1 \times 10^{-1}$ & $2.6 \times 10^{-1}$ & $1.1 \times 10^{-1}$ & $1.3 \times 10^{-7}$ \\
\hline Leukemia, low LET & $9.6 \times 10^{-8}$ & $2.6 \times 10^{-1}$ & $4.8 \times 10^{-8}$ & $1.3 \times 10^{-1}$ \\
\hline All Other & $2.3 \times 10^{-6}$ & $2.3 \times 10^{-6}$ & $1.2 \times 10^{-6}$ & $1.2 \times 10^{-6}$ \\
\hline Total & $4.4 \times 10^{-6}$ & $3.8 \times 10^{-5}$ & $2.2 \times 10^{-5}$ & $1.9 \times 10^{-6}$ \\
\hline
\end{tabular}

* individual lifetime cancer risk, assuming lifetime exposure, from USEPA (1991); divide USEPA risk factors (risk per $\mathrm{pCi} /$ ) by two to get risk per pCi/day.

Table C-4. Risk factor distribution for Ra-226 and Ra-228 (lognormal distributions, risk per $\mathrm{PCi} /$ day).

\begin{tabular}{lll}
\hline Parameter & ${ }^{226} \mathrm{Ra}$ & ${ }^{228} \mathrm{Ra}$ \\
\hline Arithmetic Mean & $1.5 \times 10^{-6}$ & $1.0 \times 10^{-6}$ \\
Standard Deviation & $9.0 \times 10^{-7}$ & $1.4 \times 10^{-6}$ \\
Lower 90\% Confidence Limit & $9.4 \times 10^{-7}$ & $4.7 \times 10^{-7}$ \\
Upper 90\% Confidence Limit & $2.2 \times 10^{-6}$ & $1.9 \times 10^{-6}$ \\
\hline
\end{tabular}

Radium is retained in bone and delivers a dose over the remaining lifespan of the exposed individual. The risk factors calculated by the USEPA model RADRISK take account of the total dose accumulated by tissues after intake (called the committed effective dose equivalent), and assume a lifetime exposure. 
Retention is the amount of a substance remaining in a tissue or organ at some time after uptake. Within 10 years after an initial intake of radium, most of the radium in the body has been eliminated (Norris et al., 1955). This observation suggests a way to adjust the USEPA lifetime risk factors (and the distributions of risk factors) for exposure periods less than a lifetime. If ten years (to account for the radium left in the body, and delivering a dose after intake and uptake have stopped) is added to the expected exposure period, the maximum risk factor for the expected exposure period can be calculated:

$$
R F(E P)=\frac{(E P+10) \times U R F_{70}}{70 y}
$$

where:

$\mathrm{RF}(\mathrm{EP})=$ risk factor as a function of exposure period EP (lifetime risk per pCi/day)

$E P=$ exposure period (years)

$\operatorname{URF}(70)=$ USEPA unit risk factor for lifetime exposure (lifetime risk per pCi/day)

This modified risk factor was used in the probabilistic risk assessment for radium described in this report. This method will slightly overestimate the committed dose, but the estimate is less conservative than assuming a seventy year exposure when such an assumption is not realistic.

\section{C.3 Effects on Aquatic Organisms}

Exposure to ionizing radiation can result in injury at the molecular, cellular and whole body levels. Most of the available studies of the effects of radiation on aquatic organisms are concerned with the induction of deterministic, somatic effects. These effects include increases in mortality and pathophysiological, developmental and reproductive effects. There is little information available concerning induction of cancer and genetic effects, although a few studies of stochastic genetic effects in organisms are available (Anderson and Harrison, 1986).

Reproductive and early developmental systems of vertebrates are the most sensitive to radiation, and invertebrates appear to be relatively resistant (NCRP, 1991).

Most studies of the effects of radiation on aquatic organisms were performed in the laboratory, with effects determined on individual animals. A few studies of the effects of radiation on natural populations have been performed. The most important consideration on assessing the effects of radionuclides discharged in produced water is the influence radiation exposure has on reproductive success in populations, and consequences in populations and ecosystems. If exposures are limited to protect fertility and fecundity of the population as a whole, it is 
unlikely that other effects in individuals will be important to the population (NCRP, 1991).

IAEA (1976) and Templeton (1980) examined the possible effects of chronic, low level radiation on recruitment, fecundity and mortality by considering the known regulatory mechanisms of natural populations. Recruitment for highly fecund species is not directly related to standing stock size and the mortality rate operating on eggs and larvae varies from year to year. Survival of eggs and larvae depend to a large degree on the availability of food, and a large number of eggs are produced at each spawning (Templeton, 1980). Density dependent mortality reduces fish larvae populations to the level that can be supported by the available food. If mortality is enhanced by low levels of radiation, recruitment to the stocks of highly fecund fish is not likely to be affected, unless the stocks are already at risk due to over-exploitation or other environmental stresses (IAEA, 1976; IAEA, 1988; NCRP, 1991).

For species with low fecundity (e.g., sharks and marine mammals), recruitment is closely related to parent stock size. It is not possible to predict the effects on recruitment for these species, although effects could be more significant than for highly fecund species. However, at low dose rates, it is reasonable to assume that effects will be small compared to fishing and other pressures (IAEA, 1976). For species with special social value (endangered and threatened species, marine mammals) effects on individuals may be of importance.

Effects at the ecosystem level have been demonstrated only for the large doses received at Eniwetok and Bikini atolls in the Pacific Proving Grounds (Templeton, et al., 1971).

The National Council on Radiation Protection and Measurements recently reviewed the literature on the effects of ionizing radiation on aquatic organisms, and suggested reference levels that would protect aquatic populations (NCRP, 1991). Major conclusions of this review included:

- Experimental studies in the laboratory have shown detectable effects on fecundity down to $10 \mathrm{mG} / \mathrm{d}$.

- Effects not necessarily deleterious at the population level have been detected at dose rates between 1 and $10 \mathrm{mGy} / \mathrm{d}$. Deleterious effects on natural populations were observed at dose rates $\geq 10 \mathrm{mGy} / \mathrm{d}$. Clearly deleterious effects which would be detected at the population level appear in the range of $10-100 \mathrm{mGy} / \mathrm{d}$.

- Lowest dose rate causing no effect in natural populations: $0.5 \mathrm{mGy} / \mathrm{d}$; lowest dose rate causing no effect in laboratory: $10 \mathrm{mGy} / \mathrm{d}$. 
NCRP (1991) suggests a reference dose rate to protect aquatic populations of $10 \mathrm{mGy} / \mathrm{d}$. NCRP also suggests a detailed assessment if an initial analysis results in estimated dose rate above $2.4 \mathrm{mGy} / \mathrm{d}$.

IAEA (1988) suggested similar reference dose rates where effects on aquatic biota would be minimal. IAEA (1988) concluded that:

- increased mortality is expected above $10 \mathrm{mSv} / \mathrm{hr}(240 \mathrm{mSv} / \mathrm{d})$;

- reduced reproductive success may occur between 1 and $10 \mathrm{mSv} / \mathrm{hr}$ (24$240 \mathrm{mSv} / \mathrm{d}$ );

- some somatic effects which would be eliminated by natural selection could occur between 0.004 and $1 \mathrm{mSv} / \mathrm{hr}(0.1-24 \mathrm{mSv} / \mathrm{d})$; and

- no adverse effects are expected below background levels of $0.004 \mathrm{mSv} / \mathrm{hr}$ $(0.1 \mathrm{mSv} / \mathrm{d})$.

\section{C.4 References}

Anderson, S.L., and F.L. Harrison, 1986, Effects of Radiation on Aquatic Organisms and Radiobiological Methodologies for Effects Assessment, USEPA Report No. 520/1-85-016, United States Environmental Protection Agency, Washington, D.C.

Federal Register, 1991, Environmental Protection Agency, National Primary Drinking. Water Regulations; Radionuclides, 40 CFR Parts 141,142, 56:138:33050.

IAEA, 1976, Effects of lonizing Radiation on Aquatic Organisms and Ecosystems, Technical Report Series No. 172, International Atomic Energy Agency, Vienna.

IAEA, 1988, Assessing the Impact of Deep Sea Disposal of Low Level Radioactive Waste on Living Marine Resources, Technical Reports Series No. 288, International Atomic Energy Agency, Vienna.

ICRP, 1977, Recommendations of the International Commission on Radiological Protection, International Commission on Radiological Protection, ICRP Publication 26, Pergamon Press, Oxford.

ICRP, 1979, Limits on Intake of Radionuclides by Workers, International Commission on Radiological Protection, ICRP Publication 30, Part 1, Vol 2 , Pergamon Press, Oxford.

ICRP, 1991, "1990 Recommendations of the International Commission on Radiological Protection", Publication 60, Annals of the ICRP, 21:1-3, Pergamon Press, Oxford. 
Layton, D.W, B.J. Mallon, D.H. Rosenblatt and M.J. Small, 1987, "Deriving Allowable Daily Intakes for Systemic Toxicants Lacking Chronic Toxicity Data", Regulat. Toxicol. Pharmacol. 7:96-112.

NAS, 1988, Health Risks of Radon and Other Internally Deposited Alpha Emitters, National Academy of Sciences, National Research Council, Committee on the Biological Effects of lonizing Radiation, (BEIR IV), National Academy Press, Washington, 1988.

NCRP, 1991, Effects of lonizing Radiation on Aquatic Organisms, NCRP Report No. 109, National Council on Radiation Protection and Measurements, Bethesda, Md.

Norris, W.P., T.W. Speckman and P.F. Gustafson, 1955, "Studies of the Metabolism of Radium in Man", Am. J. Roentgenol. Radium Ther. Nucl. Med. 73:785-802.

Rowland, R.E., A.F. Stehney and J.H. Lucas, Jr., 1978, "Dose Response Relationships for Female Radium Dial Workers", Radiat. Res. 76:368-383.

Rowland, R.E., A.F. Stehney and J.H. Lucas, Jr., 1983, "Dose Response Relationships for Radium-Induced Bone Sarcomas", Health Physics 44(Suppl. 1):15-31.

SAB, 1991, Review of the Office of Drinking Water Criteria Documents and Related Reports for Uranium, Radium, Radon and Manmade Beta-Gamma Emitters, EPA Science Advisory Board, Radionuclides in Drinking Water Subcommittee, Radiation Advisory Committee.

Stebbings, J.H., H.F. Lucas, and A.F. Stehney, 1984, "Mortality from Cancers of Major Sites in Female Radium Dial Workers", Am. J. Ind. Med. 5:435-459.

Templeton, W.L., 1980, "Ecological Effects of Transuranics in the Marine Environment". in: Radiation Effects on Aquatic Organisms, N. Egami, ed., Park Press, Baltimore. pp 3-12.

Templeton, W.L., Nakatani, R.E. and E.E. Held, 1971. "Radiation Effects".: in: Radioactivity in the Marine Environment. National Academy of Sciences, Washington D.C. pp. 223-240. 
USEPA, 1991, Final Draft For the Drinking Water Criteria Document on Radium, Prepared for the Drinking Water Standards Division, Office of Ground Water and Drinking Water, Office of Water, United States Environmental Protection Agency, Washington, D.C.

Woodhead, D.D., 1984, "Contamination Due to Radioactive Materials" in: 0. Kinne (ed)., Marine Ecology, Vol V, Part 3: Pollution and Protection of the Seas - Radioactive Materials, Heavy Metals and Oil, John Wiley and Sons, New York, New York. 